$$
\begin{aligned}
& \text { UNIVERSIDADE DE SÃO PAULO } \\
& \text { FACULDADE DE FILOSOFIA, LETRAS E CIENCIAS HUMANAS } \\
& \text { DEPARTAMENTODE LETRAS CLASSICASE VERNACULAS } \\
& \text { PROGRAMA DE POSS-GRADUAÇÂO EM LETRAS CLÁSSICAS }
\end{aligned}
$$

JULIO DE FIGUEIREDO LOPES REGO

\title{
ALOSIS/PERSIS
}

A POÉTICA DO SAQUE E DESTRUIÇÃO DE CIDADES NA ÉPICA HOMÉRICA

versão corrigida

SÃO PAULO

2020 
JULIO DE FIGUEIREDO LOPES REGO

\title{
ALOSIS/PERSIS
}

\section{A POÉTICA DO SAQUE E DESTRUIÇÃO DE CIDADES NA ÉPICA HOMÉRICA}

\author{
versão corrigida
}

Tese apresentada ao Programa de Pós-graduação em Letras Clássicas da Faculdade de Filosofia, Letras e Ciências Humanas da Universidade de São Paulo como parte dos requisitos para obtenção do título de Doutor

Orientador: Prof. Dr. Christian Werner

SÃO PAULO

2020 
Autorizo a reprodução e divulgação total ou parcial deste trabalho, por qualquer meio convencional ou eletrônico, para fins de estudo e pesquisa, desde que citada a fonte.

Catalogação na Publicação

Serviço de Biblioteca e Documentação

Faculdade de Filosofia, Letras e Ciências Humanas da Universidade de São Paulo

R343a

Rego, Julio de F. Lopes

Alosis/Persis: A poética do saque e destruição de cidades na épica homérica / Julio de F. Lopes Rego ; orientador Christian Werner. - São Paulo, 2020. $160 \mathrm{f}$.

Tese (Doutorado)- Faculdade de Filosofia, Letras e Ciências Humanas da Universidade de São Paulo. Departamento de Letras Clássicas e Vernáculas. Área de concentração: Letras Clássicas.

1. Epopeia (poesia épica). 2. Literatura

Clássica. I. Werner, Christian, orient. II. Título. 


\section{ENTREGA DO EXEMPLAR CORRIGIDO DA DISSERTAÇÃO/TESE \\ Termo de Ciência e Concordância do (a) orientador (a)}

Nome do (a) aluno (a): ___ JULIO_DE_FIGUEIREDO LOPES REGO_

Data da defesa: __02_/_ $04 \ldots /$ 2020_

Nome do Prof. (a) orientador (a): CHRISTIAN_WERNER

Nos termos da legislação vigente, declaro ESTAR CIENTE do conteúdo deste EXEMPLAR CORRIGIDO elaborado em atenção às sugestões dos membros da comissão Julgadora na sessão de defesa do trabalho, manifestando-me plenamente favorável ao seu encaminhamento e publicação no Portal Digital de Teses da USP.

São Paulo, _31___ $05 \_$___ 2020_
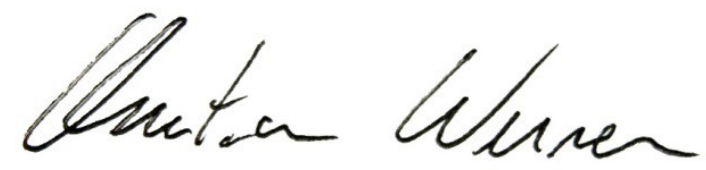

(Assinatura do (a) orientador (a) 


\section{RESUMO}

REGO, J. Alosis/persis: a poética do saque e destruição de cidades na épica homérica. Tese (Doutorado) Faculdade de Filosofia, Letras e Ciências Humanas da Universidade de São Paulo, 2020.

Embora trate-se de um tema verificado em poesia épica grega arcaica, o saque de cidades, salvo raríssimas exceções, não recebeu a mesma atenção dos demais. Em geral os poucos estudos realizados sobre o tema se concentraram em narrativas acerca da destruição da cidade de Troia e, ao mesmo tempo, o referencial teórico e os procedimentos medológicos da chamada Teoria Oral ainda não foram utilizados para este tema de forma abrangente. É justamente esta lacuna que o este trabalho procura preencher, rastreando as características elementares e reconstruindo o quadro tradicional de referências do saque e destruição de cidades.

Palavras-Chave: Homero; Épica Grega Arcaica; Saque e Destruição de Cidades. 


\section{ABSTRACT}

REGO, J. Alosis/Persis: The Poetics of City-sacking in the Homeric Epics. Tese (Doutorado) Faculdade de Filosofia, Letras e Ciências Humanas da Universidade de São Paulo, 2020.

Although it is a well-known theme in ancient greek epic, city-sacking, with rare exceptions, has not been studied comprehensively as the others. So far, research has sought exclusively to examine stories about the fall of the city of Troy, whilst the theoretical approach and the methodological procedures of the so-called Oral Theory have not yet been fully applied to this theme. It is precisely this gap that this work seeks to fill by compiling the elementary characteristics and reconstructing the framework of tradicional references of City-sacking in the Homeric epics.

Keywords: Homer; Ancient Greek Epic; Sacking of Cities. 


\section{SUMÁRIO}

1 INTRODUÇÃO

1.1 OS "CAMINHOS DA CANÇÃO" NA POESIA HOMÉRICA

1.2 O VOCABULÁRIO DO SAQUE E DESTRUIÇÃO DE CIDADES

2 A GLÓRIA

2.1 TROIA 1.0

2.2 TEBAS DAS SETE PORTAS

2.3 ISMARO

2.4 NÉRICON 69

3 OS DESPOJOS 73

3.1 TEBAS-SOB-PLACO 73

3.2 LIRNESSO E PÉDASO

3.3 LESBOS E ESQUIRO 91

3.4 TÊNEDO 95

4 AS VÍTIMAS 98

4.1 TROIA 2.0 98

4.2 CÁLIDON E PLÊURON

4.3 A CIDADE NO ESCUDO 123

4.4 TEBAS-SOB-PLACO 128

5 CONCLUSÃO 138

REFERÊNCIAS 148 


\section{INTRODUÇÃO}

Uma característica inconfundível da cidade homérica são as suas muralhas. Muito embora os detalhes da sua construção não tenham deixado senão rastros, sabe-se que eram

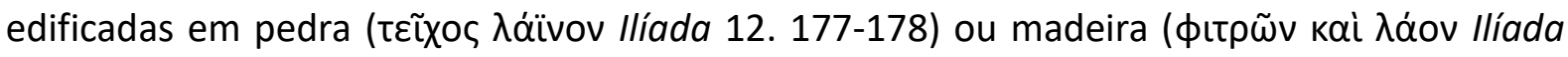

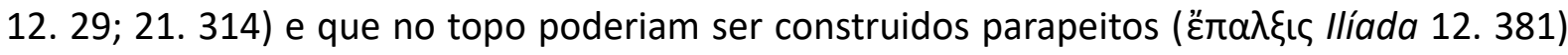

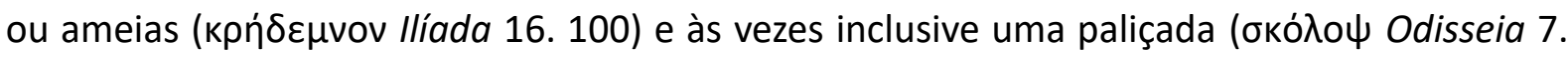
45). Dentre os seus epítetos recorrentes, encontramos os adjetivos "longas" ( $\mu \alpha \kappa \rho \alpha ́$ llíada 4.

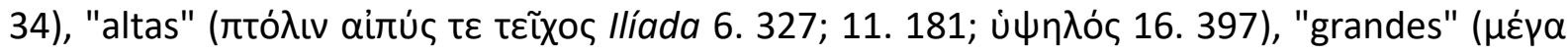
Ilíada 7. 463; 12. 12), no entanto, soldados conseguem escalá-las com facilidade e saltar para o outro lado em segurança (por exemplo, 9. 589). Presume-se, então que, ou bem a sua construção era concebida como que em patamares, ou não eram efetivamente tão altas. Em contrapartida, como indicam os epítetos "fortes" (åpeıov llíada 4. 407), "bem construídas"

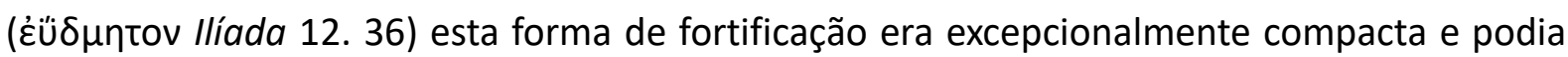
com tranquilidade alojar pelos seus adarves um número considerável de pessoas (llíada 3. 149-153; 18. 514).

O sistema de muralhas compreendia portões ( $\pi u ́ \lambda \alpha \iota$ llíada 2. 809; 7. 438) equipados

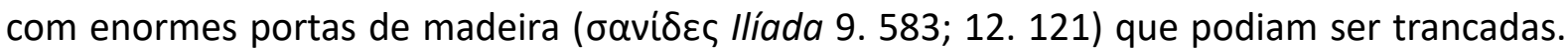
Geralmente, quanto maior é a cidade, maior o seu número de portas. A cidade de Troia tinha

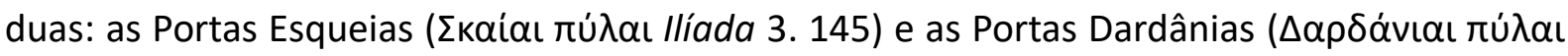

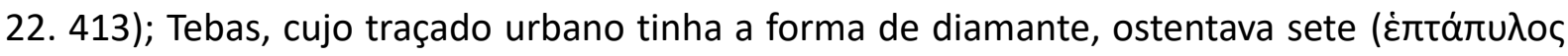

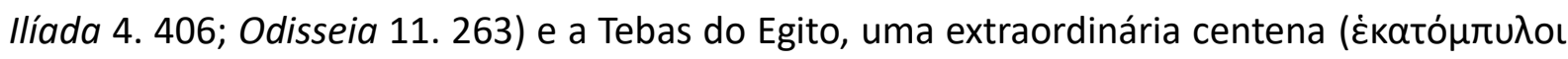
Ilíada 9. 381). Semelhantes estruturas eram também extremamente espaçosas, dado que, no decorrer de um ataque inimigo, eram capazes de acomodar muita gente preocupada no topo (llíada 3. 149-153).

Não são apenas as grandes cidades que se cercam de muralhas. Na perifeira de Troia, por exemplo, as presumivelmente pequenas Lirnesso, Tebas-sob-Placo, ambas capturadas e destruídas por Aquiles, também possuíam seu sistema de muralhas e seus "altos portões"

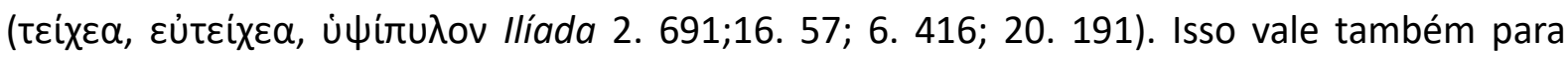


outras cidades no continente heleno, como Cálidon e Plêuron na Etólia (Ilíada 13. 217) e a obscura Feia na Arcádia (Ilíada 7. 135). Estas muralhas quase sempre recebem menção, sempre no contexto de batalha, quando são sitiadas ou quando são destruídas. Nos demais contextos, a sua existência é presumida. Quando os Feácios foram forçados a abandonar HIpéria, devido ao vandalismo e pilhagens constantes promovidos pelos ciclopes, o primeiro ato oficial do rei Nausítoo ao chegar à ilha de Esquéria é construir ao redor de sua cidade as

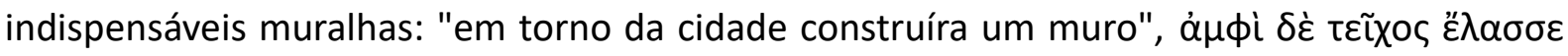

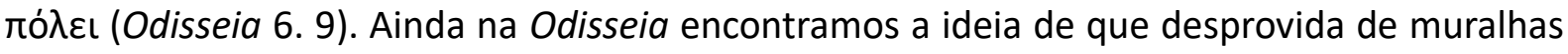
nenhuma cidade conseguiria sobreviver: Anfíon e Zeto fundam a cidade e "as muralhas lhe puseram, visto que sem elas não podiam/ viver na ampla Tebas poderosos embora fossem",

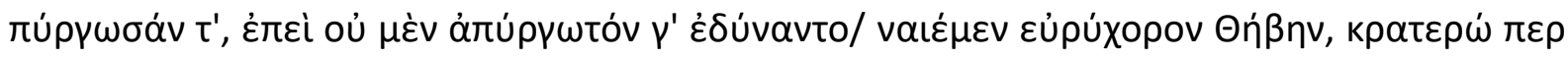

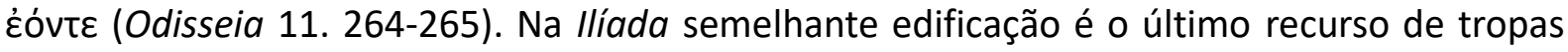
em debandada: "mantende nas mãos os portões abertos até que as hostes/ espavoridas

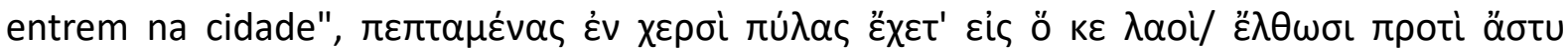

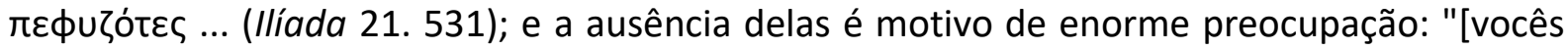

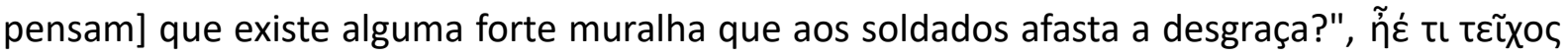

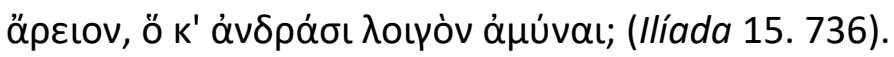

No interior da cidade homérica encontramos outras edificações características, como casas, praças e templos. Encontramos amiúde nos poemas menções à existência de estradas (ápuıaí Odisseia 2. 388) frequentemente para estabelecer relações temporais na narrativa, com o uso da expressão formular (11x) "o sol pôs-se e [e as sombras cobriram as estradas]",

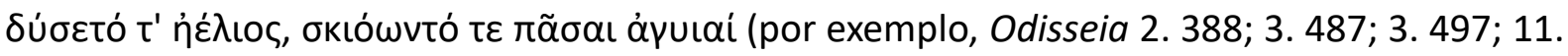
12, 15. 185). No caso das cidades de Atenas e Micenas, suas ruas são "amplas" (عủpuápula Odisseia 7. 80; Ilíada 4. 52). Em Troia, além de "amplas" (Ilíada 2. 141), as ruas recebem o

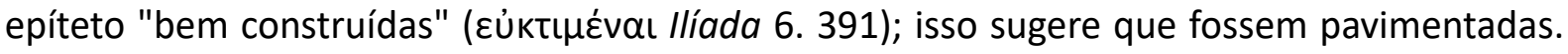
Presume-se também que ao seu redor aglomeravam-se casas, talvez em número elevado, muito provavelmente de forma compacta. Outra característica conspícua é a presença de uma praça pública ou mercado (ảyopń, sobretudo Odisseia 2. 1 ss., 8. 4-45). A praça pode ser de terra batida ou receber pavimentação: "a ágora é feita de blocos de pedras encastoados

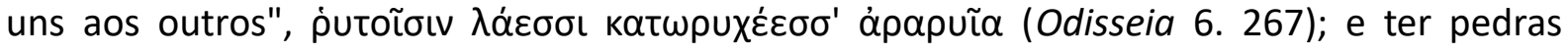


polidas de mármore organizadas em círculo para servir de assento aos líderes (llíada 2. 99; 18. 503-505; Odisseia 8. 7; 8. 16). Enquanto nas cidades de Troia e Pilos a praça fica diante da porta da casa dos líderes (Ilíada 7. 345; 2. 788; Odisseia 3. 407), em Esquéria e Ítaca, eles precisam caminhar um pouco pela cidade para chegar até ela (Odisseia 8. 4-5; 7. 43-44; 6. 262-266; 2. 10-11; 17. 61-85).

Nas proximidades encontram-se os templos e altares dos deuses. Não são muitas as referências aos templos encontradas nos poemas: A llíada menciona o templo de Atena na cidadela de Troia (vnòv AAnvaíns Ilíada 6. 88, 269, 297) e na cidade de Atenas (Ilíada 2. 549) e o templo de Apolo em Troia (Ilíada 5. 446, 7. 83). Além de mencionar o templo de Atena em Atenas (Odisseia 7. 81), a Odisseia faz referência ao templo de Poseidon em Esquéria (Odisseia 6. 10). O templo de Atena em Troia é notável por sua estátua impressionante que,

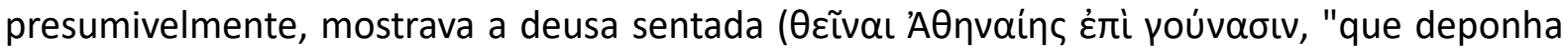
esta veste no joelho de Atena" Ilíada 6. 92). O templo de Atena em Atenas é descrito como

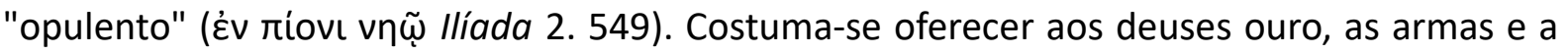
armadura de inimigos derrotados, vestimentas ricamente coloridas, e pendurar semelhantes presentes nas paredes dos templos (Ilíada 7. 82-83; 6. 90-92).

A construção e manutenção de muralhas e fortificações, fontes e lavatórios públicos, altares e templos, praças públicas e estradas sugerem uma comunidade bem organizada, viva e rica. Todos os dias os homens se reúnem na praça pública. Eles chegam logo pela manhã, carregando as suas lanças e espadas, às vezes na companhia de seus cães, tal como Telêmaco (Odisseia 2. 11). Eles se sentam em grupos ou ficam de pé, negociando transações comerciais e informando-se das novidades. Se alguém retorna de uma viagem, logo se torna o foco das atenções e as pessoas se reúnem em magotes à sua volta (Odisseia 17. 65-70). Depois disso, eles retornam para casa para tomar uma refeição e cumprir com as obrigações cotidianas, mas podem retornar à praça mais uma vez no fim do dia para jogar conversa fora. Todavia, as mulheres não frequentam a praça pública, mas esbarram-se pelas ruas (Ilíada 20. 251-255) e, certamente, têm tempo para conversas nas fontes e nos lavatórios públicos. Não é estranho, portanto, que o homem homérico sinta grande afeição por sua cidade natal, que a chame de

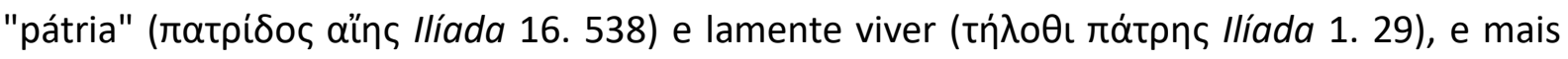
ainda morrer, afastado dela: "assim estava destinado que longe dos familiares e da pátria/ 


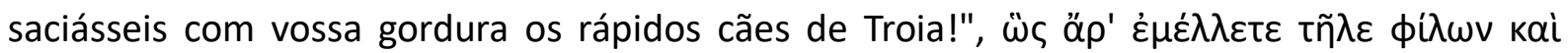

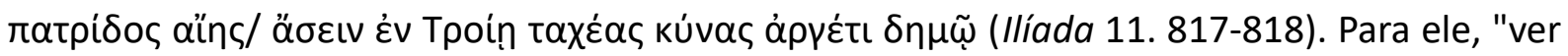
subir o fumo de sua terra" (Odisseia 1. 58-59) é a melhor coisa de todas (Odisseia 9. 25-36).

Contudo, para citar um verso proverbial encontrado nos poemas homéricos: "o ferro

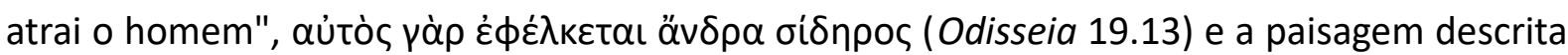
acima está sempre sob a ameaça da guerra, do saque e arrasamento. Na llíada as referências são numerosas e detalhadas. Aquiles, por exemplo, se vangloria de ter saqueado vinte e três cidades ao todo: "doze cidades de homens eu destruí com as minhas naus;/ por terra afirmo

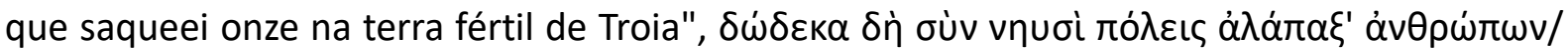

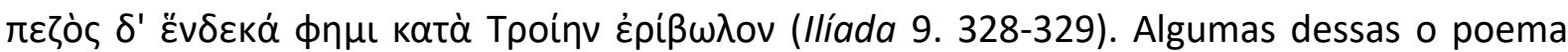
menciona pelo nome: Tebas-sob-Placo, Lirnesso, Pédaso, Lesbos, Esquiro e Tênedo, enquanto as outras permanecem na obscuridade. Ao lado de Aquiles, só Héracles pode se gabar de ter destruído "cidades", empregando o plural: "[depois de saquear] muitas cidades de guerreiros

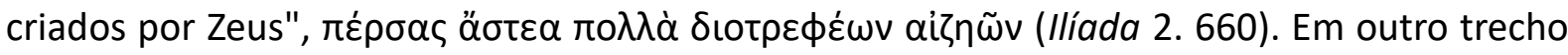
do poema, Tlepólemo narra a tomada de Troia por Héracles: "saqueou a cidade de Ílion",'I $\lambda$ ío

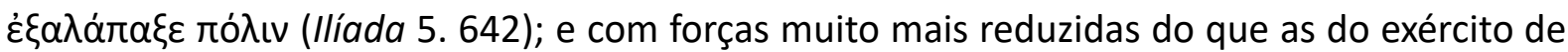

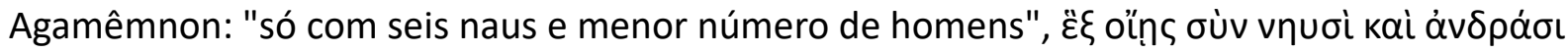
raupotépoıøıv (Ilíada 5. 649). Estênelo e Diomedes enaltecem a sua façanha de saque e de destruição em termos semelhantes: "conquistamos a sede da heptápila Tebas/ quando

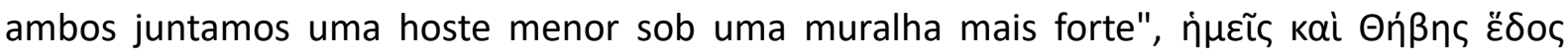

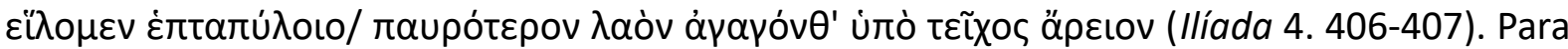
o sitiador a destruição de uma cidade parece ser sempre motivo de orgulho.

Na Odisseia, claro, Odisseu é que se gaba de arrasamentos semelhantes: "saqueamos

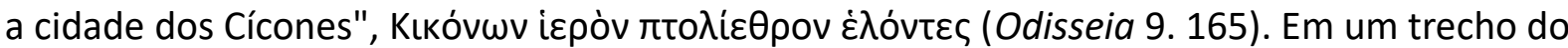
poema, ele pede a um aedo para contar a história do cerco da cidade dos troianos, graças ao seu artifício do cavalo, "que o divino [Odisseu] levou para a acrópole pelo dolo/ depois de o

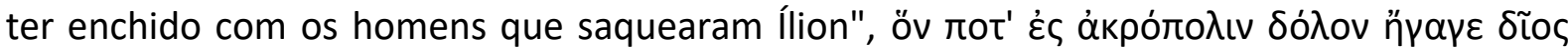

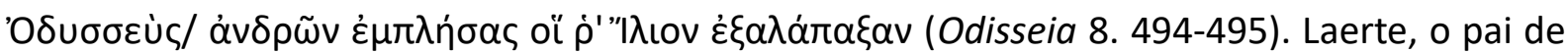
Odisseu, também relembra, em certa altura da Odisseia, os seus dias de eversor de cidades e muito nostalgicamente sonha ter outra vez a força de juventude, "quando conquistei Néricon 


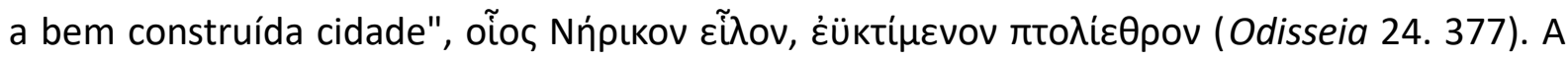
arte verbal homérica inclusive dispõe de uma palavra, um epíteto, para descrever os agentes

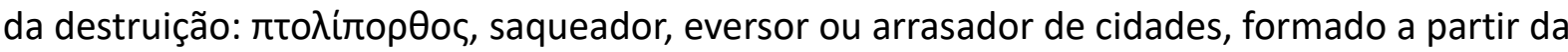

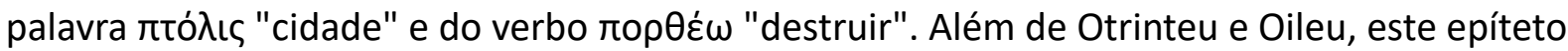
é empregado quase unicamente para descrever Odisseu, Aquiles, Ares, o deus da carnificina, e Ênio, a deusa do dissenso (Ilíada 5. 333; 15. 77; 20. 152; Odisseia 22. 283).

Quando um narrador-personagem ou o narrador homérico recorda uma das histórias de cerco de cidades, muito frequentemente o foco narrativo se volta para o butim de guerra, sobretudo quando se narra sob a perspectiva do sitiante. Geralmente os despojos se dividem

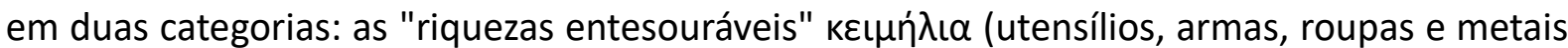
preciosos) e as mulheres cativas. Eles são levados para o acampamento e, depois, divididos entre o exército, às vezes as cativas são escolhidas a dedo pelo soldado, às vezes a escolha é, possivelmente, pública. Em relação aos saques de Tebas-sob-Placo, Lirnesso, Pédaso, Lesbos,

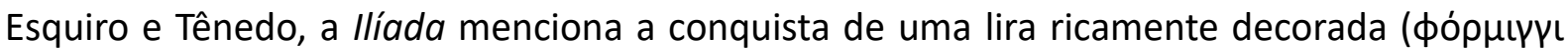

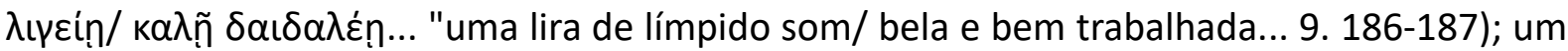

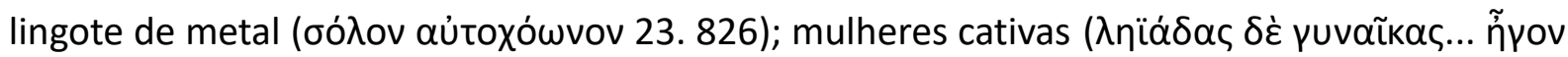

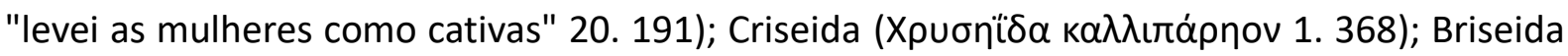

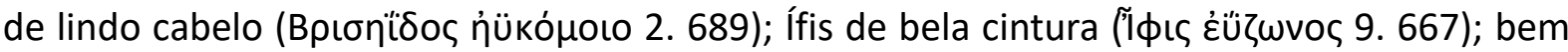

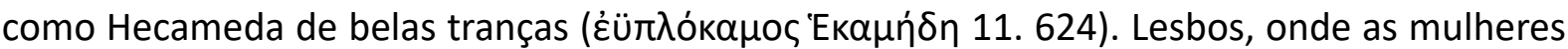
eram reconhecidas pela beleza e havia inclusive concursos, está particularmente associada às cativas de guerra. Nela capturou-se Diomeda de lindo rosto ( $\Delta$ เо outras. Agamêmnon escolhe sete dessas mulheres para presentear Aquiles, não só por causa da sua bela aparência, sempre enfatizada pelo epíteto, mas também porque eram "mulheres

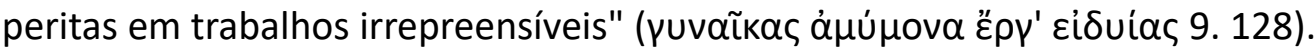

Odisseu menciona os dois componentes básicos dos espólios de guerra homéricos na sua narrativa da destruição de Ismaro: "da cidade levei as mulheres e muitos tesouros, que

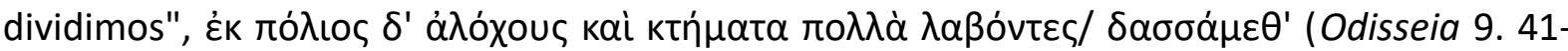
42). Por vezes, os saqueadores estabelecem relações afetivas com as cativas de guerra. Notese, por exemplo, a sucinta narrativa embutida acerca da genealogia de Tlepólemo. Héracles, depois de conquistar Éfire, leva Astioqueia como cativa ("fora trazida de Éfire de junto do rio 


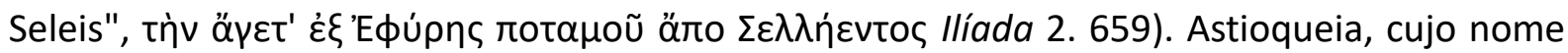
sugere relação com a aristocracia, concebe Tlepólemo. Existem evidências de que essa forma de micronarrativa, em que saqueadores se apaixonam por cativas e cativas por saqueadores, poderia ser desenvolvida em um núcleo narrativo próprio, como o poema perdido Saque de Ecália (ver também schol. bT ad llíada 6. $35=214$ Merkelbach-West = 292 Most). De maneira semelhante, o relacionamento entre Aquiles e Briseida também é um dos motores da llíada.

Dentre os despojos amealhados por Aquiles nas conquistas na Tróade acha-se ainda o irrepreensível Pédaso, um cavalo (llíada 16. 150). Todavia, a presença do cavalo, assim como, às vezes, de outros animais de rebanho, pode ser atribuída às razias de gado, uma forma de combate não-convencional, repentina e isolada da batalha campal e da subsequente tomada de uma cidade.

Embora os despojos sejam mencionados muito frequentemente, ficará claro que não são uma unidade obrigatória, indispensável, nestas narrativas. Pelo contrário, a menção aos espólios de guerra, em termos da arte verbal homérica, constitui uma ferramenta narrativa adaptável. Esta ferramenta é singularmente produtiva quando o narrador precisa apresentar algum objeto especial ou deseja enfatizá-lo. Desta maneira, pode acontecer de um apetrecho importante, como os saqueados jarros de vinho ismárico, apareça muito repentinamente saído do meio de despojos: "tínhamos suficiente porque cada tripulação ficara/ com muitos

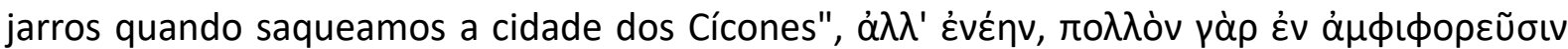

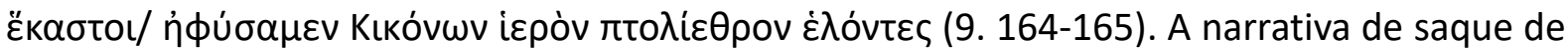
cidades e descrição do butim é certamente parte integrante da arte homérica de amplificatio e está por detrás de outras estratégias narratológicas.

Estas narrativas também fazem referência ocasionalmente aos campeões e protetores da cidade, bem como aos soberanos, membros da aristocracia. Em um determinado excerto da llíada, ouvimos falar que os irmãos lanceiros Mines e Epístrofo combateram na defesa da cidade de Lirnesso: "quando destruiu Lirnesso e as muralhas de Tebas/ tendo derrubado os

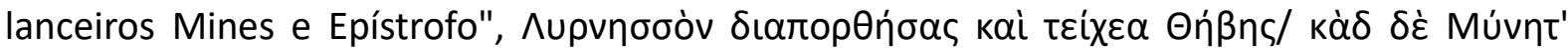

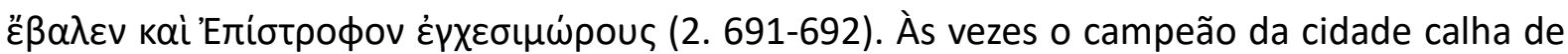
ser também o soberano, tal como Eécion, soberano de Tebas-sob-Placo. Nestes versos isso é impossível entrever: "Fomos para Tebas, a sagrada cidade de Eécion/ saqueamo-la e de lá 


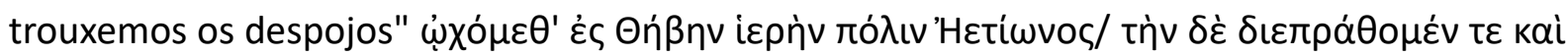

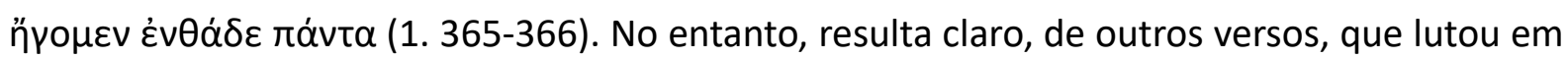
campo de batalha ou sob as muralhas na proteção da sua cidade: "arrasou a cidadela bem habitada dos Cilícios/ Tebas de altos portões. Assassinou Eécion, porém não/ o despojou de

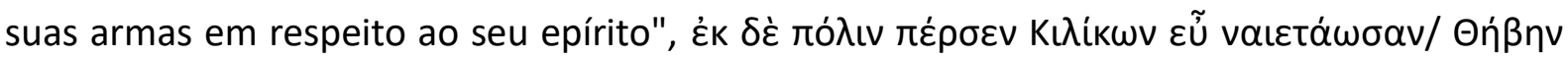

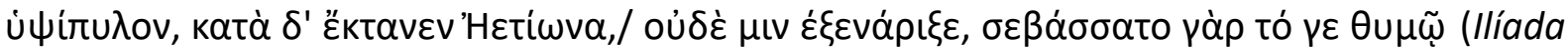
6. 415-416). Fenômeno similar acontece em llíada 19. 296 em que Mines, o lanceiro, parece

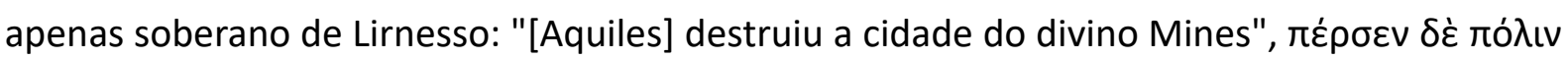
Ecíoı Múvntoc (19. 296). Ainda nesta mesma passagem inferimos um determinado padrão, segundo o qual Mines seria, presumivelmente, marido de Briseida. Reconhecer semelhante padrão suscita perguntas sobre personagens que não são descritos com detalhe e sugerem interpretações: seria Briseida uma princesa?

Embora seja raro nas analepses de saque de cidades, um narrador-personagem ou o narrador homérico pode mencionar as vítimas humanas. Odisseu sobre Ismaro: "aí saqueei a

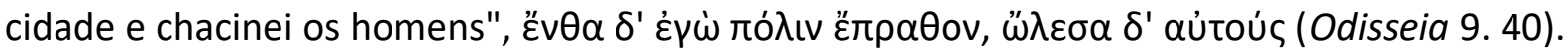
A carnificina pode também ganhar contornos poéticos, como em um discurso de Tlepólemo tencionando a olhos vistos a depreciação de Sarpédon: "[Héracles] saqueou a cidade de ílion

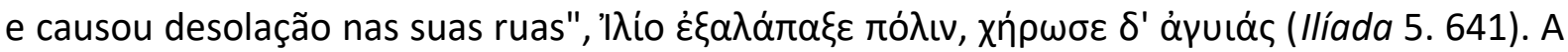
segunda parte deste hexâmetro pode também ser traduzida literalmente por "tornou as suas

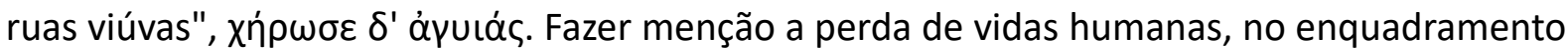
do tema de captura e destruição de cidades, parece mais natural nos discursos lutuosos de lamento. Andrômaca lamenta a morte de membros de sua família e escravidão na captura e destruição da cidade de Tebas-sob-Placo: "meu pai foi morto pelo divino Aquiles", n̆toı yà

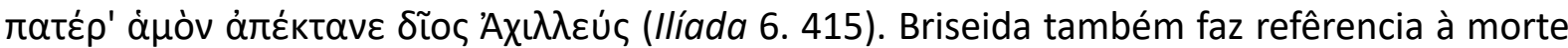
do marido e três irmãos por ocasião do cerco de Lirnesso. Os detalhes da carnificina podem de quando em quando ser arrepiantes: "vi [meu marido] à frente da cidade [rasgado em

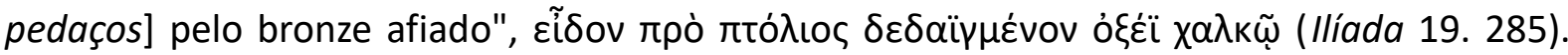
Essas descrições cumprem a função básica de provocar pathos e devem ser comparadas às sintéticas anedotas biográficas que costumam acompanhar alguns heróis caídos na llíada.

Não encontramos descrição detalhada do saque e do que ocorre com as vítimas nem 
mesmo no coração da Odisseia, na canção que narra o estratagema do cavalo de madeira. 0 narrador sumariza a famosa história como se fosse outro episódio de emboscada astuciosa e de excelência guerreira na vida de Odisseu. Talvez procurando evitar ferir susceptibilidades ou sob as amarras de alguma forma de decoro poético, a referência às atitudes das tropas no interior da cidade ou ao destino das vítimas, sempre toma uma forma oblíqua, indireta, por meio de símiles, prolepses, contrafactuais, exortações, lamentos, sempre indiretamente.

No episódio do cavalo de madeira, por exemplo, Odisseu é comparado a uma escrava, uma cativa de guerra recém-capturada. Este é um dos símiles mais extraordinários e tocantes da poesia grega arcaica. Ele reformula uma ideia que mecionamos anteriormente, a imagem da esposa que testemunha a morte do marido em combate desde a cidade: "vi [meu marido]

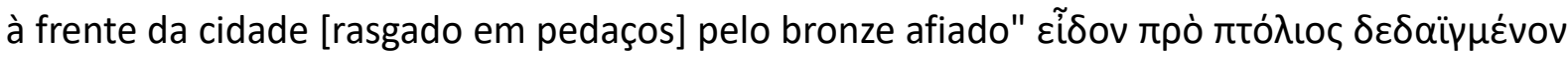

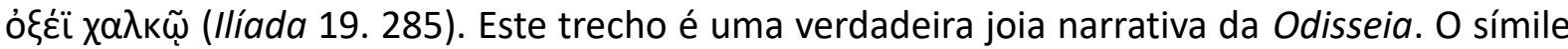
compara o choro de Odisseu, a reação do herói ao ouvir a história da destruição de Troia, ao choro da esposa que vê o marido morrer na defesa de sua cidade e é levada pelo vencedor como cativa de guerra. O símile, de um certo modo, dá sequência à narrativa do saque de Troia e, embora procure descrever o significado da morte dos protetores da cidade na figura do marido para a comunidade como um todo, concentra a sua força no destino das mulheres e das crianças e na reversão dos papéis do vencedor e do vencido, do homem e da mulher, do sitiante e do sitiado.

A referência ao destino dos derrotados por meio de prolepses é uma necessidade na llíada, uma vez que a matéria do poema não é a destruição da cidade troiana. No entanto, o narrador se esforça para incluir as imagens aterradoras do saque em desejos de destruição externado pelos aqueus e nas projeções de um futuro sem Heitor nos lamentos de Príamo e de Andrômaca. Príamo, por exemplo, lamentando a morte dos filhos e a escravização das filhas e noras, imagina "[tálamos dizimados] e crianças inocentes.../ ...atiradas ao chão em

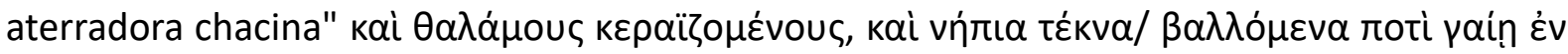

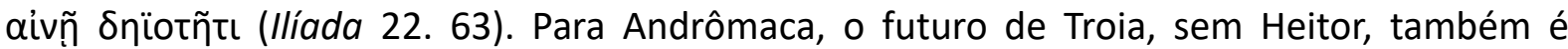
amaldiçoado. Ela teme a rotina de trabalhos humilhantes a que mulheres e crianças serão submetidas, como escravas, sob o olhar severo do seu senhor (Ilíada 24. 728-734). A morte do seu filho Astíanax também a aterroriza: "[um aqueu] pegará em ti pela mão e te lançará 


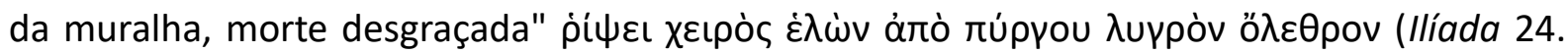
734-735).

Estas imagens são semelhantes às prefigurações, geralmente alimentadas pelo desejo de vingança, que os aqueus às vezes externam. Agamêmnon, com sua habitual brutalidade, comanda: "que nenhum [troiano] fuja da íngreme desgraça/ às nossas mãos, nem mesmo o

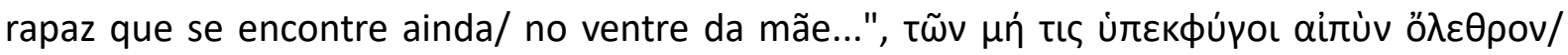

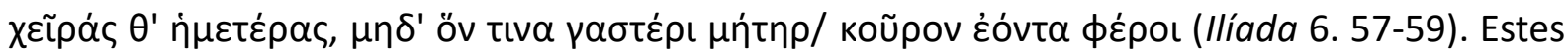
versos não somente revelam o capricho pela destruição na forma monstruosa do infanticídio, como também apresentam o destino da população masculina troiana. Agamêmnon esclarece este ponto um verso depois, quando diz "que de Ílion/ sejam todos eliminados, sem rastro

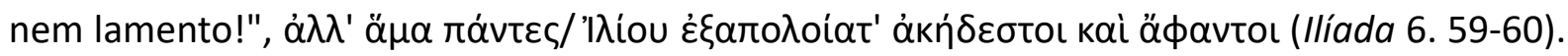
O futuro que Agamêmnon imagina para mulheres e crianças é o mesmo futuro temido por Andrômaca: "[dos troianos] comerão decerto os abutres as tenras carnes;/ pela nossa parte,

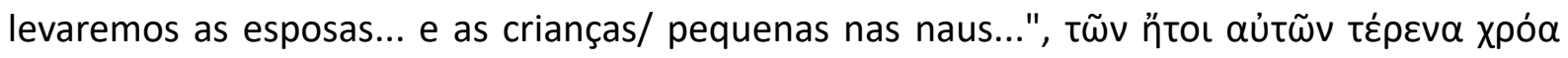

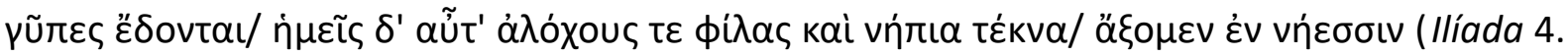
237-239). Isso aproxima o lamento de Andrômaca à exortação de batalha de Agamêmnon e

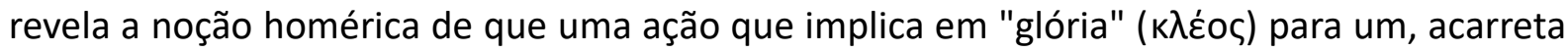
"sofrimento" ( $\pi \varepsilon \dot{v} \theta \circ \varsigma)$ para o outro. Encontramos, ainda, em uma das exortações de Nestor como que um convite, único na llíada, ao estupro: "por conseguinte, que ninguém se apresse a regressar para casa/ antes que ao lado da mulher de algum troiano tenha dormido" (Ilíada 2. 354-355)

Mas como chegamos a situações tão extremas? Aristóteles (Poética 8) já observara há muito tempo que qualquer poema épico é esculpido a partir de um todo teoricamente maior que organiza a ação narrativa, estrutura o enredo do poema e o move linearmente. Na llíada este movimento é em direção à morte de Heitor, à morte de Aquiles e à destruição de Troia. Ao lado deste movimento sequencial encontramos alusões a episódios na tradição de poesia épica que ocorrem antes dos eventos narrados no poema e a episódios que ocorrerão depois destes eventos. Ao mesmo tempo que a llíada apresenta uma narrativa limitada no tempo e no espaço (cinquenta e um dias na planície troiana), o poema passa a impressão de que está narrando todos os eventos da guerra (dez anos de combate). Em virtude dessa característica 
podemos estabelecer, ainda que de forma incompleta, as unidades básicas de expressão que constituem o padrão de enredo de um relato de guerra que culmina no arrasamento de uma cidade.

A llíada, por exemplo, faz referência aos motivos que provocam os homens homéricos a decidir pela alternativa extrema da guerra. A Segunda Guerra de Troia eclode por causa da quebra das regras de hospitalidade e do rapto de Helena. O próprio Páris Alexandre explica a causa nestes termos: "[depois de o raptar] naveguei nas naus preparadas para o alto mar",

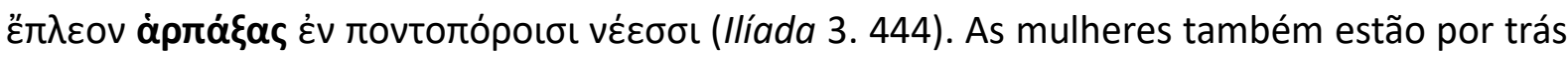
do confronto entre os lápitas e os centauros. O centauro Eurítion teria bebido vinho demais no casamento de Pirítoo, de forma que "enlouqueceu e praticou atos terríveis", $\mu a$ avó $\mu \varepsilon v o \varsigma$

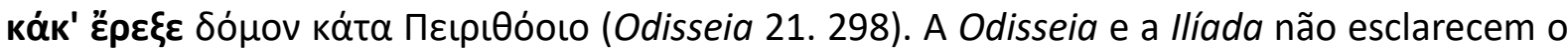
que seriam semelhantes "atos terríveis", entretanto outras fontes mencionam a violação das regras de hospitalidade na forma de assédio sexual contra as mulheres que estavam na festa. A Primeira Guerra de Troia, por sua vez, além do tratamento desrespeitoso de um hóspede, Héracles, envolve também a quebra de promessas. Um herói troiano, todavia, reduz a causa que leva à destruição à loucura do rei Laomedonte: "[Héracles] arrasou a sacra ílion/ devido aos desvarios... [de] Laomedonte", кعĩvoৎ ả

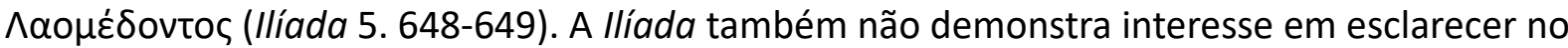
pormenor o processo que ocasionou a Primeira e Segunda Guerra de Tebas. Precisamos, por isso, recorrer a outras tradições de poesia épica. O poema cíclico da Tebaida apresenta como causa a desavença entre os irmãos Etéocles e Polinices, que disputam a herança e o trono do rei Édipo (frag. 2 Torres-Guerra $=2$ West; Trabalhos \& Dias 163). A expedição contra a cidade fracassa e os descendentes dos guerreiros derrotados, os epígonos, marcham uma segunda vez contra Tebas, com vistas a tirar vingança, e a reduzem a cinzas (llíada 2. 504). Por último, a guerra entre os pílios e os seus vizinhos epeios tem como causa uma razia de gado; conta Nestor que "quando surgiu o conflito entre os epeios e o nosso povo/ por causa do roubo de

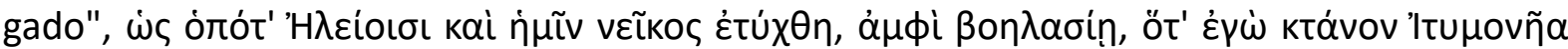
(Ilíada 11. 671-672). Em retaliação, os epeios atacam Pilos: "em roda [da cidade] acamparam,

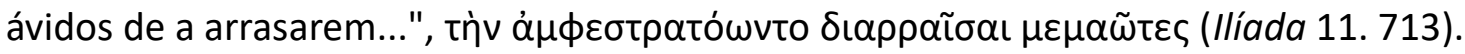

Estes conflitos, iniciados como questões de caráter privado, rápido assumem grandes 
proporções: a parte ultrajada detona um sistema de alianças para arregimentar um exército. Tideu e Polinices, nas vésperas da Primeira Guerra de Troia, viajam até Micenas para recrutar soldados, como conta Agamêmnon: "uma vez [Tideu] veio até Micenas, mas não com intento

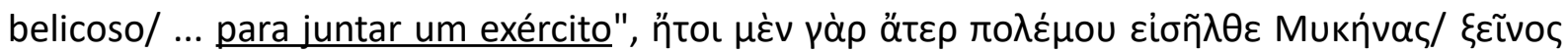

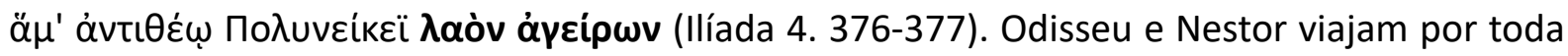

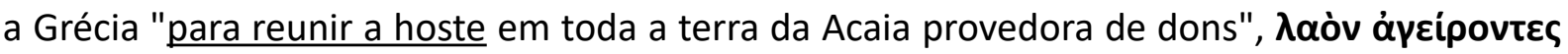

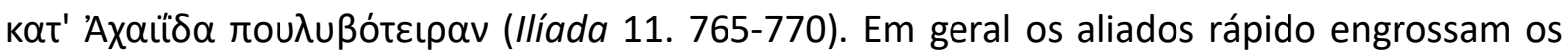
renques do exército, porém temos notícia de alistamentos espinhosos, como o de Odisseu: "Levou-nos um mês para atravessar o vasto mar, depois que/ com dificuldade convencemos

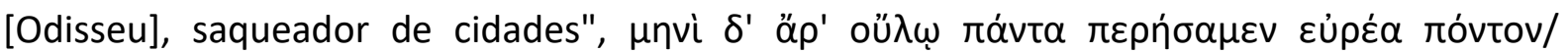

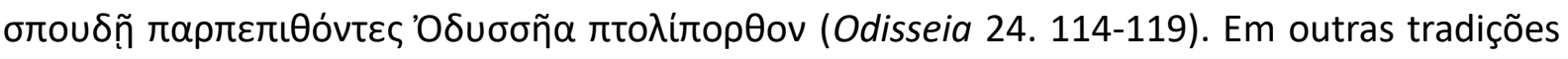
de poesia épica, como na Cípria, Odisseu pretende-se louco para escapar à convocação (arg. 119-121 Severyns; Apolodoro, Biblioteca 3.7). Em um fragmento muito controverso da Cípria, Aquiles é disfarçado de mulher para tentar pôr-se a salvo (frag. 19 West = 4 Davies). Também encontramos no poema uma menção às consequências de uma recusa: "por isso evitara... o

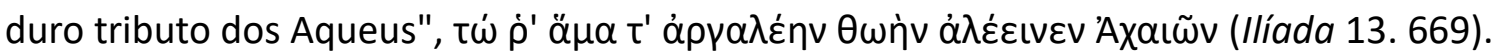

Não só os homens participam do processo de recrutamento de exércitos de aliados. A deusa Hera, por exemplo, indignada com uma sugestão capciosa de Zeus, responde: "como queres tu tornar... vão .../ o muito suor que suei, meus cavalos exaustos, quando/ chamava o

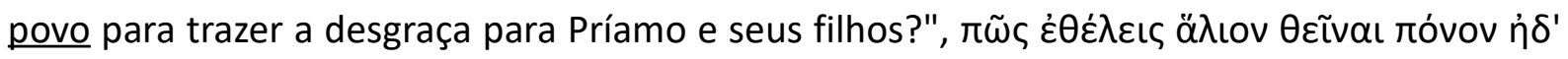

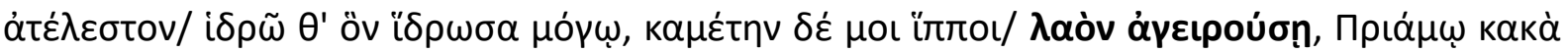

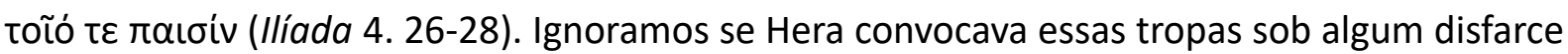
ou se acompanhava em viagem algum herói favorito, como a deusa Atena acompanha Tideu na embaixada enviada a Tebas (Ilíada 4. 370-418).

Existem evidências de que antes da reunião do exército em local pré-determinado, a narrativa poderia apresentar uma cena de despedida entre os soldados e seus pais. Em certa altura da Ilíada, por exemplo, Fênix lembra o discurso de Peleu para Aquiles antes da partida: "ó amigo! Foi a ti que teu pai Peleu deu [esta tarefa]/ naquele dia em que te mandou da Ftia

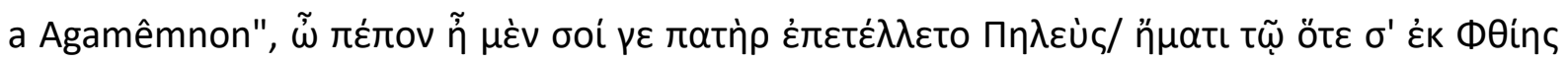

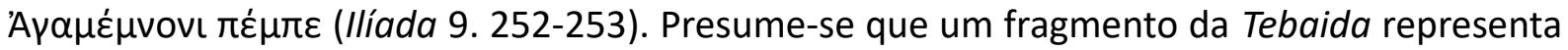


um discurso de despedida do guerreiro Anfiarau para o seu filho pequeno, Anfíloco: "preste

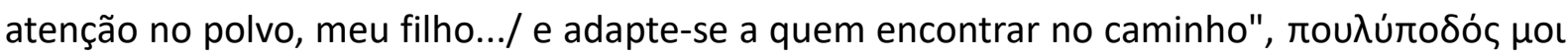

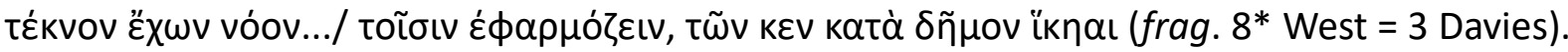
Apesar dessas evidências, é impossível comprovar que esta forma de discurso integrava uma cena-padrão de despedida.

Depois da partida, os diferentes batalhões reúnem-se em local pré-determinado para juntar suas forças ou pode haver simplesmente uma estada ou bivaque nas circunvizinhanças da cidade sob ataque. Na llíada, a frota aqueia reúne-se primeiro em Áulis antes de navegar para Troia, como Odisseu nos informa: "as naus dos aqueus/ se reuniram em Áulis, trazendo

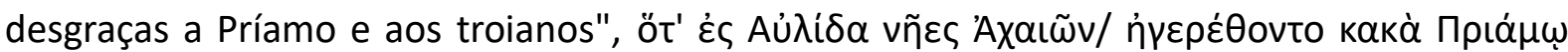

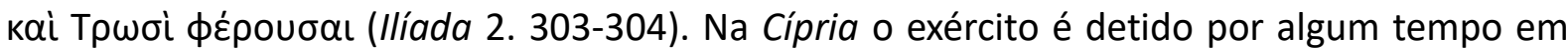
Áulis por Ártemis (arg. 135-142 Severyns). Na Ilíada o Catálogo das Naus, claramente, faz parte dos primeiros estágios da Guerra de Troia, mas é incluído na história da ira de Aquiles por efeito da convenção pars pro toto épica. O testemunho de Apolodoro acerca da Tebaida também apresenta um padrão narrativo semelhante: o exército argivo instala acampamento no território de Nemeia em busca de água (Apolodoro, Biblioteca 3.6.4). Nas duas narrativas o exército recebe portentos divinos que são interpretados favorável ou desfavoravelmente. Na llíada uma serpente devora o pardal e suas crias, o que o vidente Calcas interpreta como um sinal de que Troia será destruída no décimo ano (2. 326-329). Na Tebaida uma serpente mata um bebê, o que o vidente Anfiarau interpreta negativamente, um sinal de que a cidade de Tebas não será destruída (Apolodoro, Biblioteca 3.6.4).

Quando finalmente o exército se encontra acampado diante da cidade a ser atacada, a narrativa pode apresentar pelo menos três componentes antes dos enfrentamentos: uma

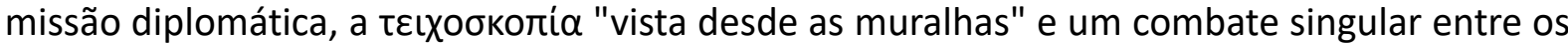
campeões do exército e da cidade ou entre os principais interessados. Na llíada encontra-se duas referências a missões diplomáticas, ambas em narrativas do tipo embutida (embbeded narrative). Um ancião troiano diz ter recebido Odisseu e Menelau em seu palácio: "uma vez

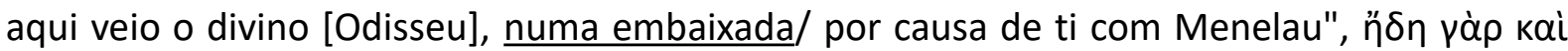

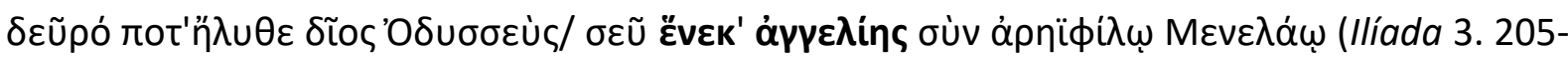
206). O ancião descreve a aparência física dos embaixadores e comenta o seu talento para a 
oratória. Em outro trecho do mesmo poema é o herói Tideu que enceta negociações com os tebanos: "foi aí que os aqueus mandaram Tideu numa [missão diplomática]", ह̌v $\theta^{\prime}$ aũ̃'

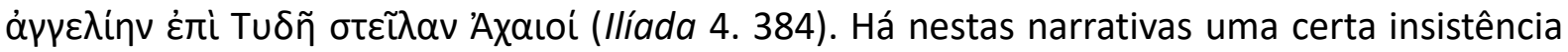
na maneira como os embaixadores usam a linguagem: "[Tideu] levou uma palavra suave aos

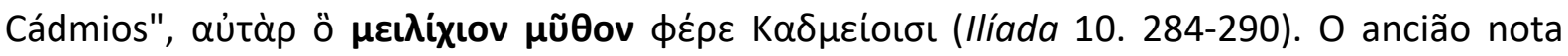
sobre Odisseu: "mas quando do peito emitia sua voz poderosa... então outro mortal não

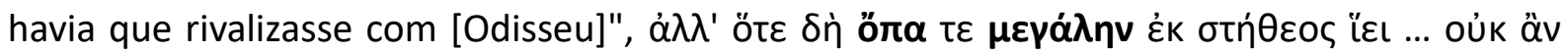

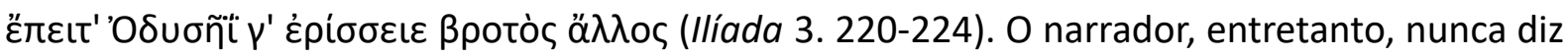
palavra sobre os pontos e condições negociados em assembleia pública.

А твцхобкоті́⿱一⿻上丨, "vista desde as muralhas", assim como o Catálogo das Naus, é outro episódio que pertence aos primeiros dias de combate e não ao décimo ano. Neste passo da Ilíada (3. 161-244) Helena identifica os comandantes do exército aqueu para Príamo e outros anciãos dos troianos. Agamêmnon, Odisseu, Idomeneu e Ajáx recebem uma descrição da perspectiva de Helena: "este é o enorme Ajax, baluarte dos Aqueus", oữos $\delta^{\prime}$ Aĭas ćoti

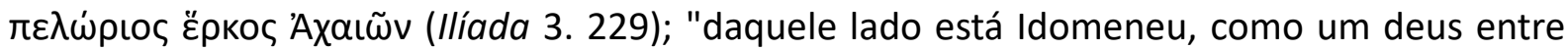

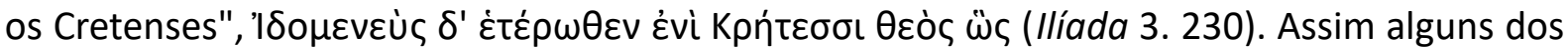
principais comandantes são descritos pelo narrador.

Dentre as ações preliminares de guerra encontra-se também o combate ritual. Tratase de uma novouaxía ou um "combate singular" em que dois oponentes se enfrentam de acordo com regras previamente estabelecidas, enquanto o restante do exército assiste. 0 combate pode envolver um campeão desafiante ou um campeão escolhido pelo exército por meio de sorteio, como no duelo entre Ájax e Heitor (Ilíada 7. 37-312). Em outra passagem da llíada, Páris Alexandre demonstra querer enfrentar Menelau em duelo nesses termos. Então, Heitor anuncia aos exércitos o desafio e as condições para o combate (Ilíada 3. 67-382). Esta cena encontra-se deslocada do começo da guerra para o décimo ano, como o Catálogo das Naus e a "vista desde a muralha". Este duelo cerimonial ganha relevância por ser a última oportunidade para que as partes interessadas resolvam a desavença sem a participação da hoste. Todavia, esta forma de duelo pode ocorrer, teoricamente, em qualquer momento da batalha.

Uma vez iniciada a batalha, as possibilidades narrativas são numerosas. A maioria das 
situações de combate ocorre em duelos, porém encontramos incursões noturnas (llíada 10), emboscadas (Ilíada 24. 34-39), aristeias (Ilíada 11. 16-283) e androktasiai (Ilíada 16. 284351), troianos e aqueus batendo em retirada (Ilíada 14. 506-522; Ilíada 8. 343-356); são muitas as alternativas. Para os propósitos do presente trabalho, o padrão narrativo mais

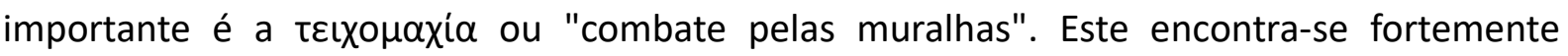
relacionado ao saque e destruição de cidades. Tal como na Tebaida, os sete comandantes do exército dos argivos se posicionam em correspondência às sete portas da cidade tebana (Apolodoro, Biblioteca 3.7.6), também os troianos lançam mão desta manobra para atacar as muralhas dos aqueus: "e organizados em cinco grupos seguiram os seus comandantes",

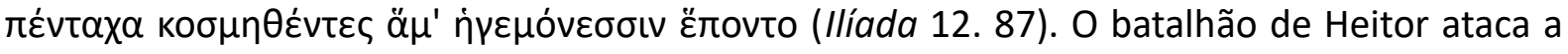
parte central das muralhas dos aqueus, enquanto os grupos liderados por Páris, Heleno e Eneias vão para o lado esquerdo da muralha. O batalhão de Sarpédon ataca pela direita.

As investidas de Sarpédon atraem a atenção de Ájax, que abandona a sua posição no centro para defender o local. Esse movimento permite que um ataque de Heitor seja bemsucedido. O troiano ergue uma pedra que "dois homens, os mais fortes da comunidade não a

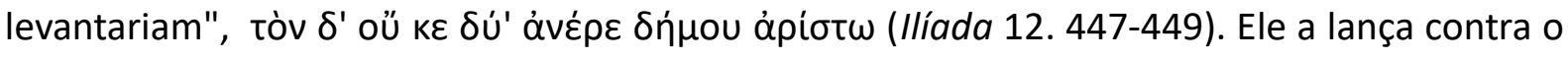
portão, que se arrebenta por completo: "Logo uns escalaram o muro/ e outros entraram pelo

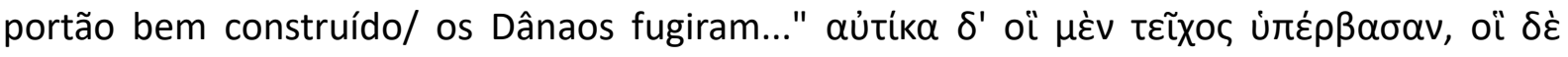

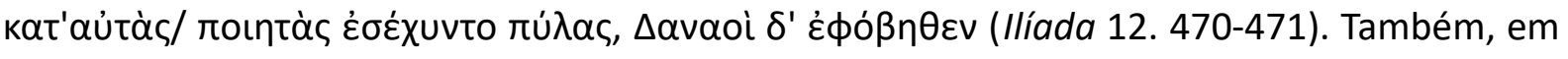
outra passagem, os arremessos e o estampido de pedras chocando contra as muralhas da cidade anunciam grande perigo: "depressa em torno dos portões retumbava o estrondo/ das

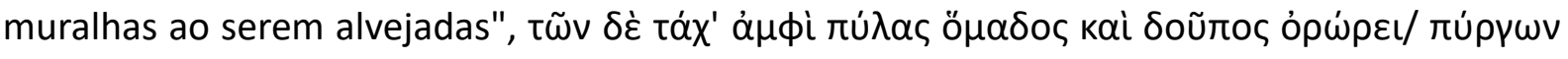
$\beta a \lambda \lambda o \mu \varepsilon ́ v \omega v$ (Ilíada 9. 573). Depois dos estrondos, a cidade de Cálidon é invadida e quase saqueada pelos seus sitiantes. Em uma das narrativas do nosso corpus também encontramos outra reviravolta surpreendente: uma cidade saqueada executa um contragolpe e expulsa os saqueadores de suas terras (Odisseia 9. 39-66).

Porém, nem toda muralha pode ser destruída e nem toda guerra é vencida pela força bruta, como a de Heitor ou de Aquiles (Ilíada 12. 447-449). Embora a "força" (ßía) de Aquiles cumpra, para a destruição de Troia, a importante função de eliminar o mais notável campeão da cidade, Heitor, é pela "astúcia" ( $\mu$ ñtı) de Odisseu que o destino de Troia é levado a cabo. 
Embora as breves narrativas estudadas neste trabalho apresentem com alguma regularidade o cerco de uma cidade em justaposição à morte do seu campeão, como se estabelecesse um vínculo de causalidade, a morte de Heitor não sela completamente o destino troiano. A llíada omite a tradição mitológica da invencibilidade das muralhas troianas, como os poemas homéricos costumam omitir propriedades mágicas e fantásticas de narrativas, personagens e objetos em geral. Acolher essa mitologia significaria ainda reduzir a importância da morte de Heitor, que o poema vincula diretamente à destruição de Troia, e a façanha do seu principal herói, Aquiles. Porém, é possível entrever semelhante tradição nos poemas. A construção do extraordinário sistema de muralhas da cidade troiana por Poseidon e Apolo é mencionada na Ilíada (21. 442-460, só por Poseidon; em 7. 453 ambos a constroem). Diz Poseidon: "construí

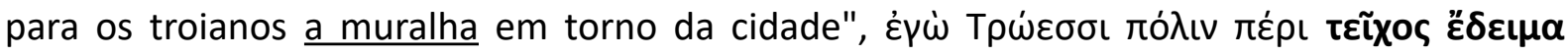
(llíada 21. 446).

A Odisseia menciona a fundação e a construção das fortificações da cidade de Tebas pelos irmãos Anfíon e Zeto (11. 260-265). Embora este poema omita a engenharia fantástica envolvida na construção das defesas da cidade, em muitas versões mitológicas, Anfíon ergue as muralhas movendo as pedras com o som de sua lira, enquanto o irmão Zeto, pastoreia os rebanhos. É possível que nestas narrativas, a obra da engenharia divina ou mágica, esteja por detrás da noção de invencibilidade. Esses elementos, próprios do conto popular (folk tale), podem explicar o motivo por que, ali onde as táticas do combate convencional fracassaram, os aqueus são forçados a recorrer à astúcia e ao estratagema do cavalo de madeira .

Os capítulos deste trabalho foram divididos em seções que correspondem a cada uma das narrativas, ou melhor dizendo, micronarrativas, sobre saque de cidades encontradas em épica homérica. No capítulo 2 abordamos a história da primeira conquista de Troia efetuada por Héracles (Ilíada 5. 633-651); de Tebas pelos epígonos (Ilíada 4. 370-418:); do saque da cidade de Ismaro por Odisseu (Odisseia 9. 39-66) e de Néricon pelo jovem Laerte (Odisseia 24. 376-382). Tais micronarrativas apresentam com regularidade um roteiro de atividades de guerra: a movimentação do exército sitiante rumo a cidade; a destruição, conquista ou saque daquela comunidade mediante o emprego de vocabulário característico; o transporte dos despojos de guerra e a partilha subsequente entre as tropas do exército. Em se tratando dos despojos, geralmente o foco da narrativa se concentra sobre as mulheres cativas, mas parece 
não existir uma regra, tanto que muitas das narrativas nem sequer as mencionam. Às vezes toca-se no auxílio prestado pelos deuses no saque da cidade, às vezes nas vítimas masculinas do combate. Em uma determinada ocasião a população sitiada, mesmo após ter a sua cidade completamente conquistada, logra reverter a situação e põe em fuga os seus sitiantes.

Os contextos em que as narrativas deste capítulo ocorrem são variados: a tomada de Ismaro por Odisseu faz parte de uma longa seção narrativa em que o personagem assume as funções de narrador; a menção à destruição de Néricon faz parte de um desejo irrealizável, que retoma uma façanha do passado de Laerte. A primeira conquista de Troia é citada em um formato característico de discurso de guerra: a provocação. Tlepólemo acusa Sarpédon de não estar a altura dos seus ancestrais, citando como exemplo uma façanha de Héracles, muito mais bem sucedido no exercício da guerra. Esse também é o contexto em que aparece a referência à destruição de Tebas pelos epígonos. Em resposta ao discurso de reprovação do comandante Agamêmnon, Estênelo apresenta a destruição da cidade de Tebas, façanha que os ancestrais dele e de Diomedes jamais foram capazes de levar a cabo. A repetição do tema do choque de gerações, presente em duas das narrativas estudadas, deu ensejo à discussão

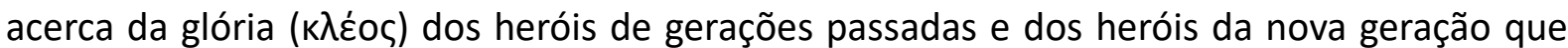
lutavam na planície troiana. Além de verificarmos uma rivalidade entre formas diferentes de glória intergeracional, observamos que esta rivalidade também deve se estender para formas diferentes de poesia épica.

Abordamos, no Capítulo 3, as narrativas da tomada de Tebas-sob-Placo (Ilíada 1. 366369; 9. 185-191; 16. 148-154; 23. 826-829); o arrasamento das cidades de Lirnesso e Pédaso (Ilíada 2. 681-694; 19. 56-62; 20.79-98 e 176-194); das ilhas de Lesbos e Esquiro (Ilíada 9. 128-130 e 665-669 ); e de Tênedo (Ilíada 11. 624-62), todas pelas mãos de Aquiles. Ao longo dessas seções verificamos a repetição do mesmo roteiro de atividades observado no Capítulo 2: a movimentação das tropas em direção à cidade, a conquista, a breve referência às vítimas masculinas e ao auxílio de uma divindade, o transporte e a divisão dos despojos. No entanto, encontramos outros elementos constitutivos do tema, tais como a referência a um indivíduo que é importante para a comunidade. Essa referência pode ocorrer de modo notadamente

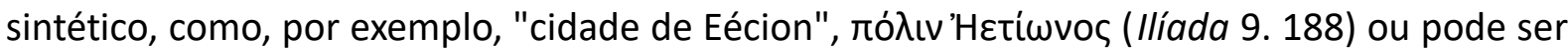
mais longamente desenvolvida, como a menção aos guerreiros caídos Mines e Epístrofo: 


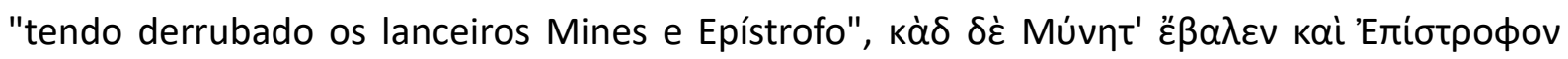

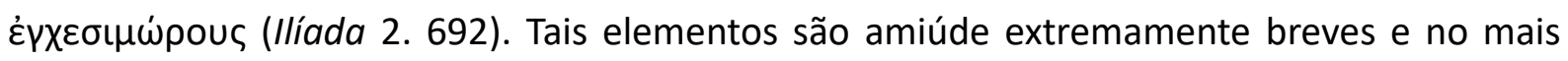
das vezes não há como determinar se o indivíduo mencionado é o soberano da cidade ou o seu campeão e defensor mais importante. Além dessas unidades, a tomada das cidades de Tebas-sob-Placo, Lirnesso e Pédaso têm em comum o fato de estarem ligadas à emboscada e à "razia de gado", uma forma de ação de combate não-convencional que frequentemente aparece sobreposta às narrativas de saque e destruição de cidades. Mas o elemento que une todas as narrativas desta divisão é insistência constante no butim de guerra. Tebas-sob-Placo, Lirnesso e Pédaso rendem ao "eversor de cidades" pelo menos uma lira de prata, um cavalo, um lingote de metal e cativas, dentre elas as notáveis Criseida e Briseida. As ilhas de Lesbos, Esquiro e Tênedo também rendem outras mais.

Os contextos em que as narrativas ocorrem são menos variados do que os do capítulo anterior. As tomadas de Tebas-sob-Placo, Lirnesso e Pédaso são mencionadas em discursos de Eneias e Aquiles antes de um combate. Porém, o arrasamento dessas cidades, bem como as capturas das ilhas de Lesbos, Esquiro e Tênedo, é mais constantemente registrado por meio da inserção de uma oração subordinada relativa ou temporal, que alude à procedência ou origem de um determinado objeto ou de uma certa mulher cativa amealhados na guerra.

O Capítulo 4 estuda a narrativa do saque de Troia por meio do estratagema do cavalo de madeira (Odisseia 8. 487-535), a quase tomada da cidade de Cálidon (Ilíada 9. 524-604), a descrição do cerco da cidade retratada no escudo de Aquiles (Ilíada 18. 508-540:) e, por fim, retornamos a Tebas-sob-Placo, porém da perspectiva dos derrotados (Ilíada 6.405-434). Tal como esperaríamos, essas passagens apresentam pontos de contato com os relatos de saque estudados nos capítulos anteriores: a movimentação das tropas, a utilização de vocabulário especializado nas descrições de arrasamento, o embate com o campeão da cidade na forma de duelo, o ajuda de um deus, menções aos despojos de guerra, sobreposição das formas convencionais de combate à emboscada (às vezes na forma da razia de gado). No entanto, foi possível detectar outros elementos constitutivos do tema do presente trabalho. A história do saque de Troia acrescenta o elemento da divisão das tropas durante o ataque; o bloqueio da cidade de Cálidon envolve, em especial, unidades relacionadas ao "combate pelas muralhas", a $\tau \varepsilon \iota \chi o \mu \alpha \chi i ́ \alpha, c o m o$ a grande ameaça do fogo e da pedra. Ao mesmo tempo, estas passagens 
apresentam uma ênfase na representação das vítimas da guerra, velhos, mulheres e crianças, cujo destino de morte e servidão é aludido em diferentes contextos mediante um símile, um discurso, e expressões formulares bem estabelecidas.

Quanto aos contextos, o saque de Troia é narrado em uma canção; o baldado intento de conquistar Cálidon é contado em um paradeigma; o cerco da cidade no escudo faz parte de uma longa passagem descritiva, em que prevalece a linguagem do símile; e, finalmente, o relato da destruição de Tebas-sob-Placo encontra-se em um discurso híbrido, que combina as características do discurso de censura ou reprovação e do lamento fúnebre.

Ao longo desta tese, usamos amplamente as excelentes traduções da llíada (2013) e da Odisseia (2011) realizadas por Frederico Lourenço. Quando achamos por bem introduzir alguma modificação pontual, indicamos marcando-as por colchetes. As traduções de outros autores, bem como as minhas, encontram-se patenteadas nas notas de rodapé.

Nas variações sobre o mesmo tema apresentadas acima é possível observar padrões; ideias e linguagem se organizam como em um sistema poético. Esta tese reconhece esse fato como sendo uma consequência das condições de composição da poesia épica arcaica. A postura teórica e metodológica que este trabalho defende e adota se encontra sintetizada nesta passagem do livro de A. LORD:

"ao estudar os padrões e os sistemas de narrativas orais em versos, estamos na realidade examinando a 'gramática' desta poesia, uma gramática como que sobreposta à gramática da língua em questão. Ou, para utilizar uma metáfora diferente, encontramos uma gramática especial no bojo da gramática da língua, que é necessária à versificação. As fórmulas são frases, orações e sentenças desta gramática poética especializada. $O$ falante desta língua, depois de tê-la dominado, não precisa se virar mais mecanicamente com ela do que nós precisamos ao empregá-la na fala cotidiana".

Quando falamos uma língua, a nossa língua nativa, não reproduzimos as palavras e frases que memorizamos de forma consciente; antes as palavras e frases surgem do uso rotineiro. Isso é verdade para o cantor de contos que trabalha com a sua gramática especializada. Ele não "memoriza" fórmulas, como nós também não "memorizamos" a língua quando crianças. Ele as aprende ao escutá-las nos contos de outros cantores $e$, por 
conta do uso rotineiro, elas também se tornam parte do seu repertório de contos. A memorização é um ato consciente de apropriação de alguma coisa, enquanto que a repetição é algo considerado fixo e algo de que não se apropria. $O$ aprendizado de uma língua poética oral segue os mesmos princípios do aprendizado da própria língua, não mediante a esquematização consciente de elementos gramáticais elementares mas por meio do método natural e oral.

"In studying the patterns and systems of oral narrative verse we are in reality observing the "grammar" of the poetry, a grammar superimposed as it were, on the grammar of the language concerned. Or, to alter the image, we find a special grammar within the grammar of the language, necessitated by the versification. The formulas are phrases and clauses and sentences of this specialized poetic grammar. The speaker of this language, once he has mastered it, does not move any more mechanically within it than we do in ordinary speech".

"When we speak a language, our native language, we do not repeat words and phrases that we have memorized consciously, but the words and sentences emerge from habitual usage. This is true of the singer of tales working in his specialized grammar. He does not "memorize" formulas, any more than we as children "memorize" language. He learns them by hearing them in other singers' songs, and by habitual usage they become part of his singing as well. Memorization is a conscious act of making one's own, and repeating, something that one regards as fixed and not one's own. The learning of an oral poetic language follows the same principles as the learning of language itself, not by the conscious schematization of elementary grammars but by the natural oral method". ( $\left.{ }^{1}\right)$

O presente trabalho concorda com a observação de LORD (1960) de que os poemas homéricos exibem um sistema poético que pode ser entendido como uma língua; todavia, uma língua especial própria para a composição (e usufruição) de poesia épica. Por essa razão será possível encontrar em muitas de suas páginas menções a "expressão formular", "cenapadrão" ou "cena-típica", "tema", "padrões de narrativa" ou "padrões narrativos" e, às vezes, "padrão de enredo" ou "enredo-padrão". Cada um desses termos foram desenvolvidos pela crítica oralista de poesia homérica para descrever as "unidades de significação" desta língua 
poética especial de que fala o estudioso americano. Eles descrevem partes que compõem o sistema poético em diferentes níveis dos textos que chegaram até nós. O padrão de enredo, por exemplo, é uma estrutura que norteia a organização narrativa do poema como um todo. O padrão narrativo, por sua vez, organiza narrativas menores. A cena-padrão ou cena típica é outro princípio organizador de narrativas, mas desta vez de ações geralmente cotidianas e repetidas como, por exemplo, vestir uma armadura, uma viagem por mar, a prece a um deus e assim por diante. As expressões formulares são encontradas no nível do verso. Consistem em palavras repetidas parcial ou integralmente, que ocorrem dentro de um mesmo contexto. A significação dessas fórmulas ou expressões formulares frequentemente extrapolam o seu sentido literal.

No entanto, não se procurou aqui nesta tese definir de forma estanque e monolítica nenhum desses termos e conceitos, com o entendimento de que isso poderia mais enredar do que esclarecer. A fórmula, por exemplo, a primeira unidade de significação examinada por oralistas, ainda hoje é um problema teórico. Embora a communis opinio esteja certa sobre a sua importância e utilidade na composição e recepção dos poemas pelo público, seria errado afirmar que existe um consenso sobre a sua definição e a forma como é utilizada. Assim, por esse motivo, empregamos os fundamentos teóricos da teoria oralista sem fundamentalismo. Para nós, mais importante são os pressupostos metodológicos, que devem nortear a leitura de textos tradicionais de natureza oral.

Neste sentido é importante dizer que entendemos o "tema", unidade de significação sob estudo neste trabalho, na esteira de VIEIRA (2016), que cita a definição de NÜNLIST e DE JONG encontrada no volume das prolegomena aos comentários da Basileia sobre a llíada:

Tema: sequências de eventos recorrentes que são menos claramente estruturados e menos formulares na fraseologia do que a cena-padrão, e.g. súplicas, cenas de combate e matança, intervenção de um deus, reconhecimento ... Na literatura acadêmica germânica em especial, mas também na anglófona, existe, como resultado, sobreposição com o termo 'motiv/motif' que é com muita frequência utilizado como sinônimo de 'tema'. No presente contexto, motif indica unidades narrativas breves $e$ recorrentes que perpassam gêneros diferentes (i.e. aqueles que tem pouca relação com a épica homérica, e.g. o companheiro fiel, força vs. inteligência) e rendem, portanto, uma sequência 
gradual (com limites fluidos): motivo/ tema /cena-padrão.

Theme: recurrent sequences of events that are less clearly structure and less formulaic in their wording than actual type-scenes, e.g. supplication, scenes of battle and killing, intervention of a god, recognition ... Especially in German, but also in Anglophone scholarship, there is a resultant overlap with the term 'motiv/motif' wich is often used as synonymous with 'theme'. In the present context 'motif' indicates short, recurrent narrative units present across genres (i.e. those less clearly tied to Homeric epic, e.g 'the loyal follower', 'intelligence vs. strength') yielding an escalating sequence (with fluid borders): 'motif' - 'theme' - 'type-scene'. $\left({ }^{2}\right)$

\subsection{OS "CAMINHOS DA CANÇÃO" NA POESIA HOMÉRICA}

Na tradição de poesia hexamétrica arcaica o tema da guerra é quase onipresente. Quando os personagens desta tradição narrativa não estão efetivamente guerreando, eles conversam sobre guerra e relembram muito alegremente os combates de que participaram; mesmo quando o aedo arcaico não está contando uma história de guerra, ele pode reutilizar e adaptar técnicas de composição tradicionais e próprias deste tema para narrar histórias com pouca ou quase nenhuma relação com o assunto. $\mathrm{O}$ tema do polemos quase sempre se encontra de uma forma ou de outra dentro do horizonte da poesia hexamétrica arcaica. Isso acontece porque a guerra, assim como a captura e o saque de uma cidade, é concebida pela tradição como uma façanha extraordinária ( pratica $\left({ }^{3}\right)$.

Necessitamos começar pelo começo e responder à pergunta mais fundamental: quais são os recursos que o aedo emprega para instaurar semelhante narrativa? Do ponto de vista da tradição oral, o leque de narrativas à disposição do aedo é expresso, no epos arcaico, por um termo quase técnico que pode ser entendido como uma metáfora de viagem ou passeio: a canção é um caminho (oi̋ $\mu \eta)$ que o poeta percorre na companhia da sua audiência $\left({ }^{4}\right)$. De

NÜNLIST \& DE JONG $(2015$, p. 175).

Ver FORD (1997, pp. 396-414).

Para reflexões sobre o significado deste termo, ver CHANTRAINE, DELG, p. 783; PAGLIARO (1953, pp. 34-40); VAN GRONINGEN (1958, p. 76); DURANTE (1976, p. 176); LANATA (1963, p. 11); NAGY (1990, p. 28); FORD, 
acordo com essa noção grega de poesia, característica do Período Arcaico, o repertório de "caminhos" ou "itinerários" do aedo é um produto da inspiração divina: "um deus me pôs no

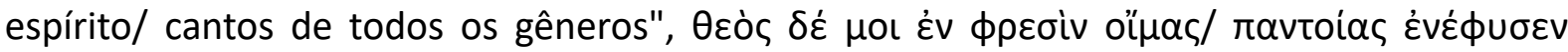

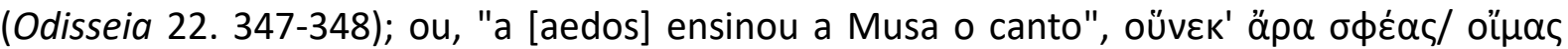

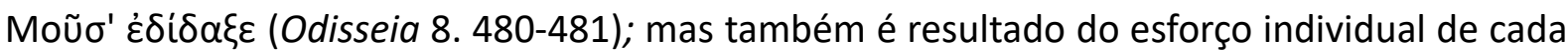

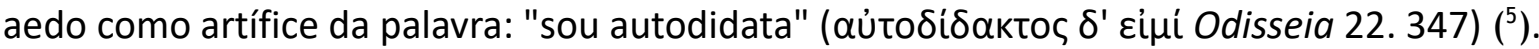

Partindo da evidência interna encontrada nos poemas homéricos, é possível postular que semelhantes "caminhos da canção" às vezes adquirem nomes, como se fossem títulos de poemas. Um cantor como o personagem Fêmio da Odisseia conheceria uma variedade de caminhos diferentes, como por exemplo: "O destino funesto dos Argivos Dânaos e de Ílion",

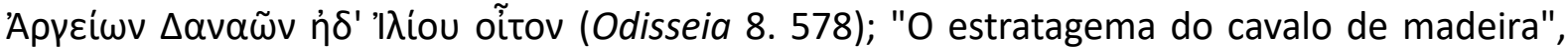

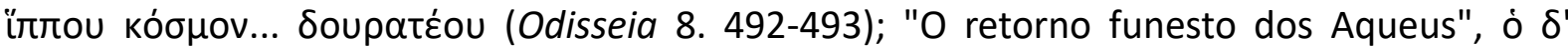

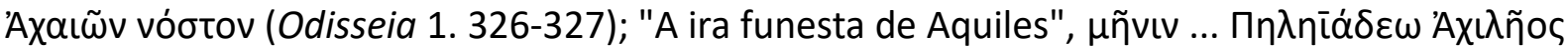

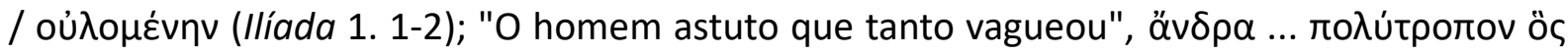
$\mu \alpha \dot{\lambda} \lambda \alpha \pi \circ \lambda \lambda \dot{\alpha} / \pi \lambda \dot{\alpha} \gamma x \theta \eta$ (Odisseia 1. 1), entre outros.

Para CAMEROTTO (2009, pp. 21-36), os principais "argumentos de canto" ou "tramas de canto" encontrados na poesia heroica podem ser arranjados em quatro grupos. 0 mais

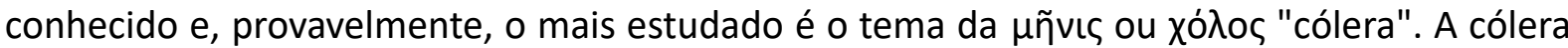
é o tema anunciado da llíada na protasis do próprio poema: "a cólera funesta de Aquiles",

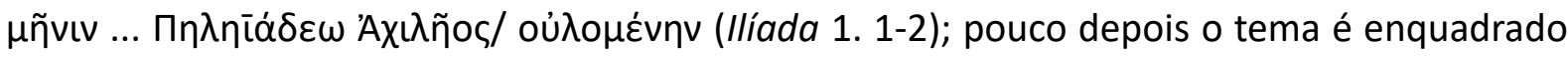

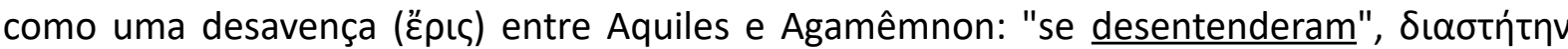

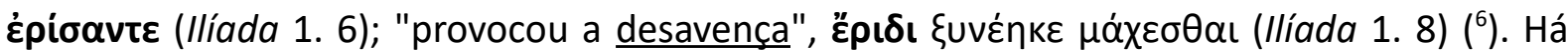
uma série de termos para expressar a ira em Homero $\left({ }^{7}\right)$, porém nenhum deles parece deter relevância tão grande quanto $\mu \tilde{v} v ı s$ no léxico tradicional dos poemas. Já foi repetidamente observado pelos comentadores que este termo é usado nas mais das vezes para expressar a

(1992, p. 42 n. 78); 1997 (p. 404); GIANNISI (2006, pp. 65-73); CAMEROTTO (2009, pp. 21-24).

5 Ver MURRAY (1981) e, mais recentemente, MURRAY (2015) sobre o equilíbrio entre impulso divino e esforço humano na concepção grega arcaica de criação poética. As traduções da llíada e da Odisseia são da autoria de Frederico Lourenço.

6 Ver GRIFFIN \& HAMMIOND (1982); REDFIELD (1979); NOTOPOULOS (1964), BASSET (1923) sobre a protasis. Ver também KIRK (1985, pp. 51-53); PULLEYN (2001, pp. 115-118).

7 WALSH (2005). IRSCHMER (1950) encontra pelo menos treze palavras para expressar semelhante emoção nos poemas homéricos. 
raiva que um deus sente diante de transgressões humanas $\left({ }^{8}\right)$. Porém, esta palavra é usada na llíada com vistas a dar magnitude à emoção e ao papel de Aquiles no épico, concentrando deste modo a força do poema no personagem. Além disto, como já observado há muito por NOTOPOULOS (1964, p. 32), existe uma relação muito íntima entre este tipo de emoção e o herói épico de forma geral, como veremos adiante ao abordarmos o segundo "argumento de canto" encontrado em poesia heroica.

Já notamos que $\mu \tilde{n} v \iota \varsigma$ costuma ser empregada para expressar a cólera de divindades diante de transgressões humanas. É este pouco mais ou menos o cenário encontrado no Hino Homérico a Deméter. A deusa sofre um ataque a sua honra ( $\tau \mu \mu \eta \dot{)}$ e deambula pela terra enlutada $\left({ }^{9}\right)$. É preciso que Zeus costure um acordo para que a deusa, que "mantém terrível

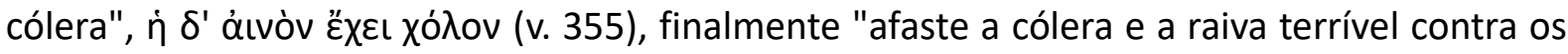

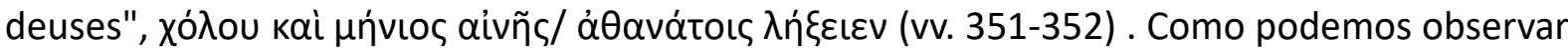

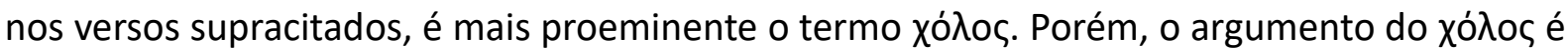
afim ao da $\mu \tilde{\eta} v ı \varsigma$, como é atestado na protasis alternativa da llíada indicada por Aristoxeno: "como a cólera e a raiva apoderaram-se do filho de Peleu e do glorioso filho de Leto", ö $\omega \varsigma$

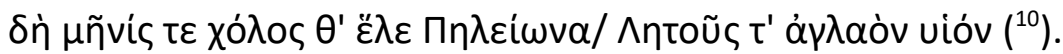

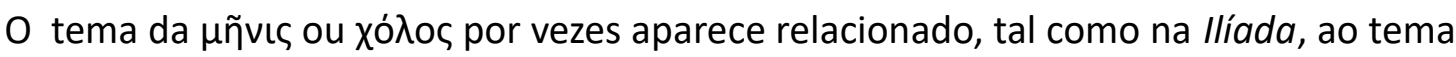

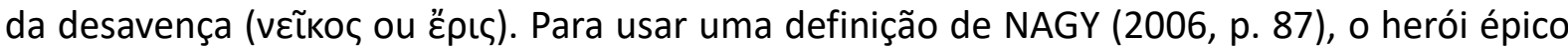
é extraordinário, para o bem e para o mal. Ao mesmo tempo que realiza façanhas grandiosas como os "trabalhos" ( reprováveis. O comportamento do herói resulta frequentemente em desavenças (vعĩкoৎ), no geral privadas, e não raro elas ganham tamanha proporção que afetam toda a comunidade. A tradicionalidade dos poemas épicos costuma localizar tais desavenças em uma variedade de situações. A maior parte delas tem lugar no contexto da divisão, seja a divisão da comida

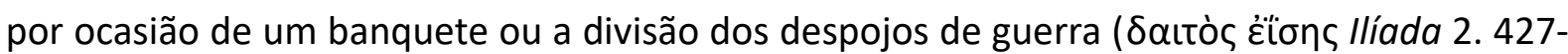
431; cuja raiz está etimologicamente relacionada aos verbos $\delta \alpha i o \mu \alpha \iota, \delta \alpha i v u \mu l, \delta \alpha i \zeta \omega, \delta \alpha i \omega$, "partilhar", "dividir"). A desavença entre Etéocles e Polinices, por exemplo, tem como causa a partilha da herança de Édipo e ocorre no contexto de um banquete (Cípria frag. 2 West = 2

8 Notavelmente, MUELLNER (2005).

9 Sobre essa interpretação e outras relações com o enredo-padrão da llíada, ver NICKEL (2003).

10 As traduções do Hino Homérico a Deméter e da protasis alternativa da llíada encontrada em Aristoxeno são minhas. 
Davies; 3 West = 3 Davies). Na llíada, a desavença resultante da incapacidade de curetes e etólios chegarem a um acordo sobre a partilha dos despojos do javali de Cálidon acarreta uma guerra (Ilíada 9. 547-548); a Odisseia também faz referência a um episódio de dissenso entre Aquiles e Odisseu no contexto de um banquete (Odisseia 8. 75-76).

Encontramos no catálogo feito por GIRARD (1902, pp. 245-247) onze ocorrências de dissenso entre heróis na tradição heróica: a desavença entre Filoctetes e os comandantes dos Aqueus em Tênedo em virtude do ferimento provocado em Filoctetes por uma serpente, como narrado na Cípria (arg. 125-128 Severyns) $\left({ }^{11}\right)$; a desavença entre Odisseu e Palamedes, como narrado na Cípria (arg. 119-121 e 166 Severyns); o desentendimento entre Aquiles e Agamêmnon acerca de Briseida $\left({ }^{12}\right)$, narrado ainda no começo da llíada: "se desentenderam",

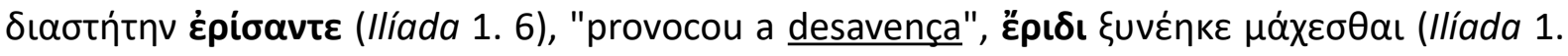
8); entre Odisseu e Tersites tal como narrado no segundo canto da Ilíada; entre Aquiles e Odisseu, o conteúdo da primeira canção do aedo Demódoco na corte de Alcínoo na ilha dos Feácios: "a contenda entre Odisseu e Aquiles, filho de Peleu/ como outrora se injuriaram no

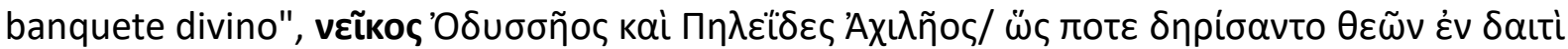

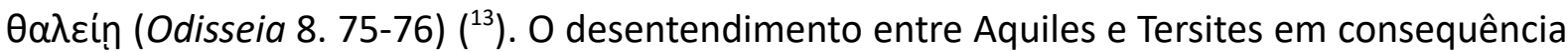
da paixão que Aquiles sentiu pela amazona Pentesileia, como narrado na Etiópida (arg. 178181 Severyns; é possível que haja uma alusão a este episódio em Ilíada 2. 220-221) ( ${ }^{14}$ ); a disputa entre Odisseu e Ájax, filho de Télamon, pelas armas de Aquiles, referida em Odisseia 11. 543-564, Etiópida (arg. 201-203 Severyns) e na Pequena llíada (arg. 208-210 Severyns). Neste episódio também podemos notar a sobreposição desses dois temas na pergunta que Odisseu coloca para a alma de Ájax: estás disposto a esquecer "a raiva por causa das armas/

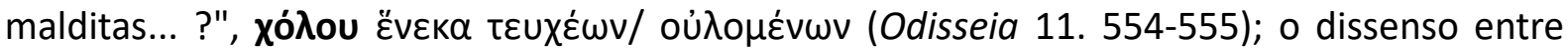
Odisseu e Ájax, filho de Oileu, que se instala por ocasião do estupro de Cassandra, narrado em Pausânias (10.31.2) e cujo julgamento é mencionado no poema Saque de ílion (arg. 261265 Severyns); entre Agamêmnon e Menelau, na narrativa de vóotoc contada por Nestor no

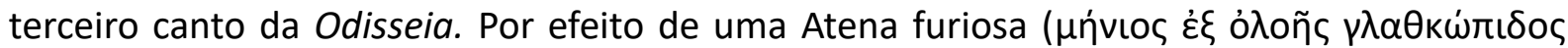

11 Para uma tradução em português, ver GATTI (2012).

12 Talvez tenha também existido outra narrativa de desavença entre Agamêmnon e Aquiles, relacionada a uma estadia em Tênedo. ver. Cípria frag. 21 West e arg. 146-147 Severyns.

13 Passagem bastante discutida na literatura: por exemplo, FINKELBERG (1987); NAGY (1979); BAKKER (2013), pp. 42.-43.

14 Para um estudo detido deste episódio e sua relação com a llíada, ver o excelente artigo de MARKS (2005). 


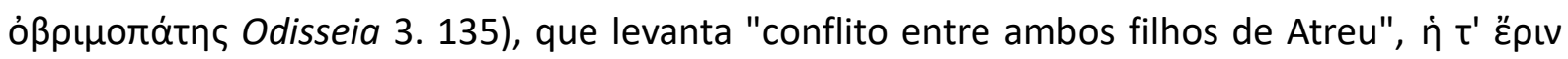

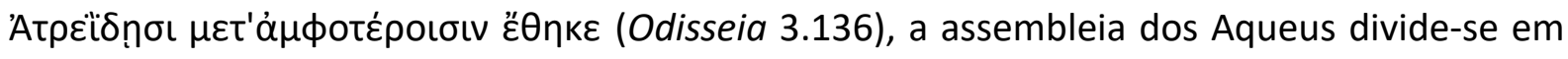
dois grupos antagônicos, um deles defendendo a permanência das tropas em Troia, o outro defendendo a sua retirada e retorno imediato para casa. O grupo que deixa Troia ainda é vítima de uma segunda desavença entre os pares: "mas Zeus não queria o nosso regresso/

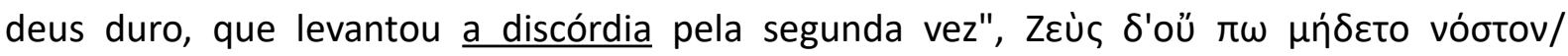

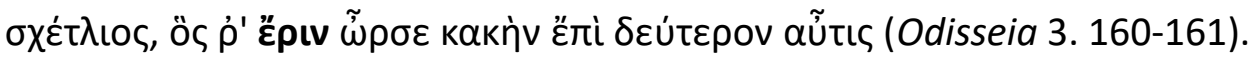

Isso nos leva ao terceiro argumento, o vóotos ou "retorno". Este tema encontra-se, reconhecidamente, na protasis da Odisseia: "foram muitos no mar/ os sofrimentos por que passou para salvar a vida/ para conseguir o retorno dos companheiros a suas casas", זo $\lambda \lambda \dot{\alpha}$

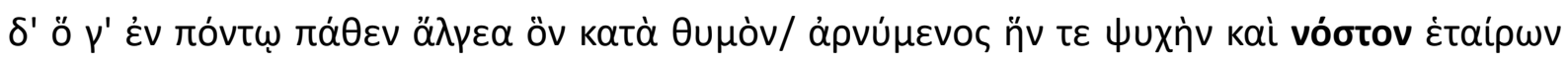
(Odisseia 1. 4-5); em outras palavras, o poema da Odisseia é uma narrativa construída sobre o argumento do retorno. A narrativa de retorno da Odisseia, além disso, encerra dentro de si mesma, mise em abîme, outras narrativas de retorno: Nestor (Odisseia 3. 100-328) começa a sua narrativa em Troia, cronologicamente, para, depois, relatar os nostoi dos outros Aqueus individualmente. Nestor narra o vóбtos de Agamêmnon (Odisseia 3. 130-156, 193-198, $303-$ 310), de Odisseu (Odisseia 3. 153-164), bem como o de Menelau (Odisseia 3. 276-302, 311312). O conteúdo das histórias contadas por Nestor deve ser igual ao da canção de Fêmio em Odisseia 1. 325-327, excetuando a parte que concerne Odisseu. Da mesma forma que Nestor, Menelau também relata, na Odisseia, a sua história de retorno (Odisseia 4. 351-586); assim também o próprio Odisseu procede em Odisseia 9-12 $\left({ }^{15}\right)$, onde narrador e narrativa são comparados ao cantor e à canção: "contaste a história com a perícia de um aedo", $\mu u ̃ \theta o v ~ \delta^{\prime}$

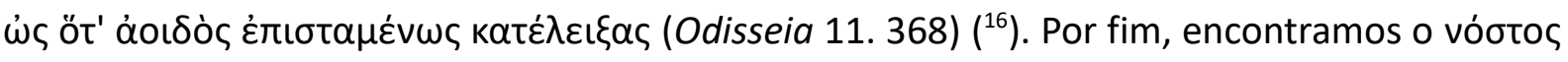
como argumento de poemas épicos fora da tradição homérica, como registra o Suda: "e os poetas que cantaram os retornos seguiram o mais de perto possível o modelo de Homero",

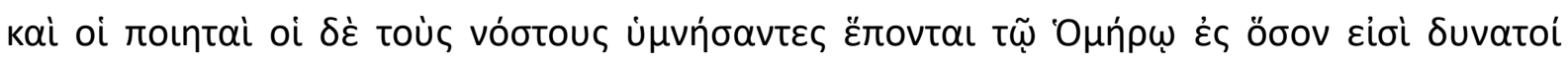
(WEST, 2003, p. 153). Temos também notícia de um poema em cinco livros ou cantos sobre o mesmo tema, cuja composição é atribuída pela tradição ao poeta Ágias de Trezena ( $\arg .94 .1$

15 Sobre as narrativas de retorno na Odisseia, ver DE JONG (2001).

16 Ver MACKIE (1997, pp. 78-91); SCODEL (1998, pp. 171-194); MINCHIN (2001, pp. 205-224). 
B Severyns = Proclo, Crestomatia 277) $\left({ }^{17}\right)$.

As narrativas de retorno encontradas na Odisseia têm, logicamente, vinculação íntima com as narrativas de captura de cidades, dado que o retorno dos Aqueus tem lugar após a captura e saque da cidade troiana. É desta forma que a protasis da Odisseia encapsula o seu tema principal, delimitando-o a partir da narrativa da Guerra de Troia: "depois que de Troia

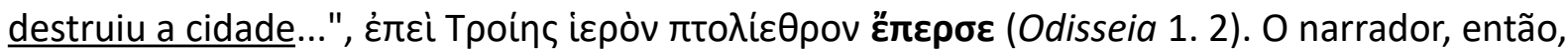
arremata: "foram muitos no mar/ os sofrimentos por que passou para salvar a vida/ para

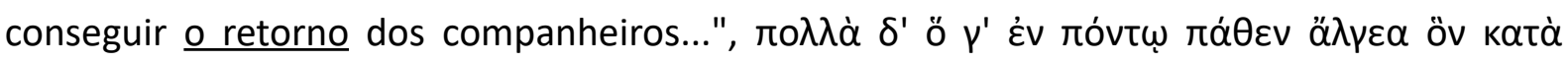

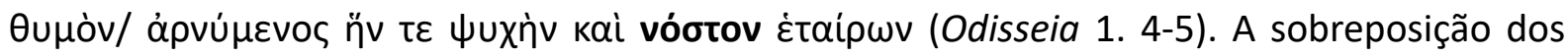
argumentos do retorno e da captura e destruição de cidades está explicitada no emprego dos

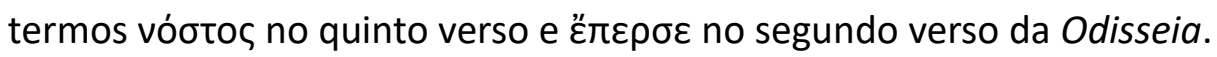

\subsection{O VOCABULÁRIO DO SAQUE E DESTRUIÇÃO DE CIDADES}

Embora CAMEROTTO (2009, pp. 27-28) empregue os termos ä $\lambda \omega \sigma \iota \varsigma$ e $\pi \varepsilon \dot{\rho} \sigma \iota \varsigma$, captura e destruição, para caracterizar o quarto e último dos principais "argumentos de canto" que se podem encontrar na poesia heroica, eles não são tão produtivos na linguagem especial da

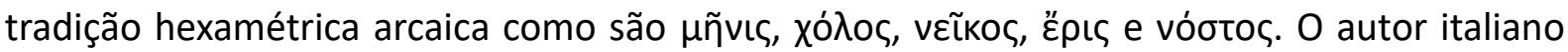
procede dessa forma porque ä $\lambda \omega \sigma \iota \varsigma$ e $\pi \varepsilon \dot{\rho} \rho\llcorner\varsigma$ foram legados pela tradição literária posterior. Em uma busca pelo Thesaurus Linguae Graecae (TLG) descobrimos que a palavra répoıৎ é mencionada em literatura clássica apenas duas vezes no corpus simplificado da ferramenta, ambas na Poética de Aristóteles, em referência ao 'I $\lambda$ íou répoıc ou Saque de ílion (1456a16 e 1459b6). Depois, na Descrição da Grécia ou Viagem à Grécia de Pausânias, encontramos três passagens em que há três menções a dois títulos de poemas: o Saque de Ílion de Lesques e o Saque de Ílion de Estesícoro $(10.25 .5 ; 10.26 .1 ; 10.27 .2)$. Já o termo ö $\lambda \omega \sigma \iota \varsigma$, por outro lado, é muito mais frequente. Pelas ocorrências atestadas no $T L G$, a palavra é usada para descrever a tomada de cidade em Ésquilo (Sete contra Tebas 117-119; Agamêmnon 589), Tucídides ( ${ }^{18}$ ), Eurípides (Hécuba 1135; Electra 1024), Sófocles (Traquínias 288, Filoctetes 61), Xenofonte

17 Sobre este texto, que faz parte dos poemas do Ciclo Épico, ver DANEK (2015).

18 1.12.3; $1.23 .5 ; 2.2 .1 ; 3.51 .1 ; 4.70 .1 ; 4.107 .3 ; 4.108 .3 ; 4.109 .1 ; 4.113 .1 ; 4.116 .2 ; 5.15 .2 ; 7.24 .2 ; 7.32 .1$. 
(Helênicas 2.3.9), Heródoto $\left({ }^{19}\right)$, Platão (Leis 685d1) e Demóstenes (Filípica 3.60.2). Por hábito esses registros apresentam o termo ö $\lambda \omega \sigma \mathrm{c}$ s seguido do nome da cidade (geralmente em

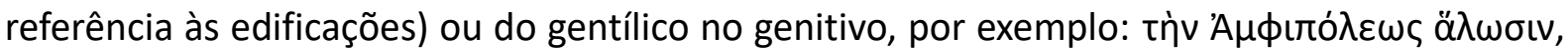
"a tomada de Anfípolis" (Tucídides, Guerra do Peloponeso, 4.108.3), 'I $\lambda$ íou ö $\lambda \omega \sigma \mathrm{\omega v}$, "a tomada de Troia" (1.12.3); ou ainda, tìv $\Sigma \alpha \rho \delta i \omega v v a ̈ \lambda \omega \sigma ı v$, "a captura de Sardes" (Heródoto, História,

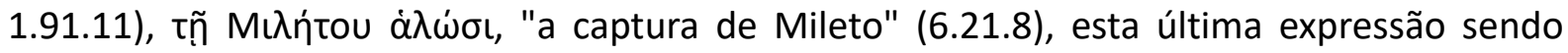
também o título de uma tragédia de Frínico.

Embora os substantivos ä $\lambda \omega \sigma \iota \varsigma$ e $\pi \dot{\rho} \rho \sigma \iota \varsigma$, canonizados como terminologia técnica pela literatura posterior, estejam ausentes dos poemas homéricos, os verbos $\dot{\alpha} \lambda \dot{\sigma} \sigma \kappa o \mu \alpha \iota$ e $\pi \varepsilon \dot{\varepsilon} \theta \omega$ de que derivam são regularmente atestados na dicção épica e engendraram fórmulas

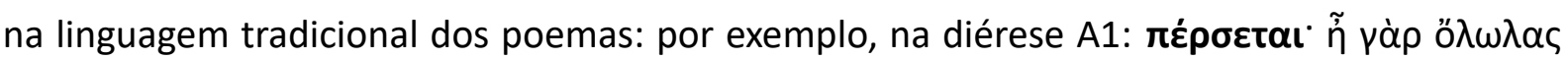

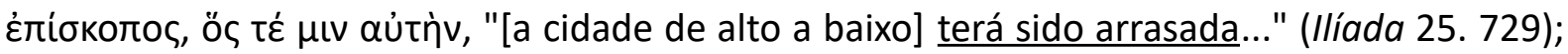

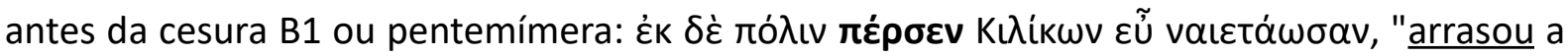
cidadela bem habitada dos Cilícios" (Ilíada 6. 415); antes da cesura B2 ou trocaica: $\mu$ ทे $\Delta \alpha$ vaoi

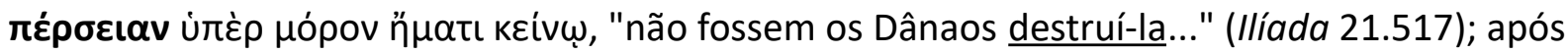

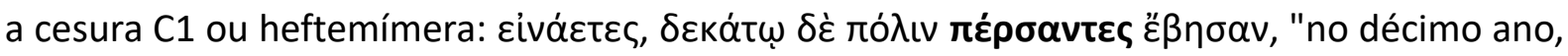

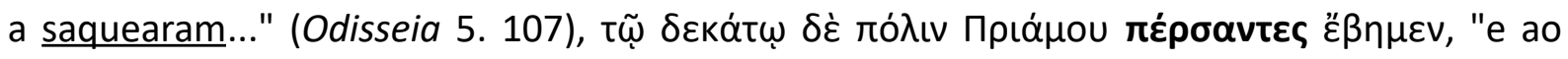
décimo ano saqueamos a cidade de Príamo..." (Odisseia 14. 241). E ainda, iniciando o verso:

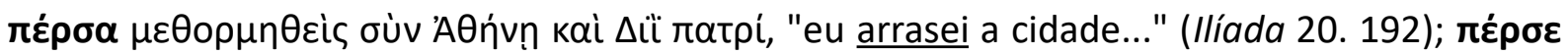

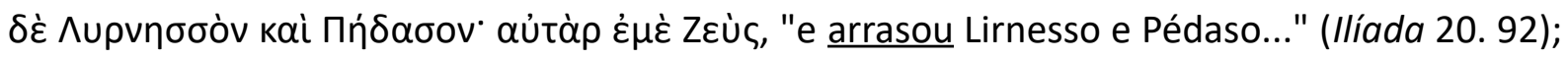

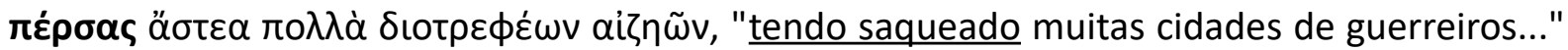

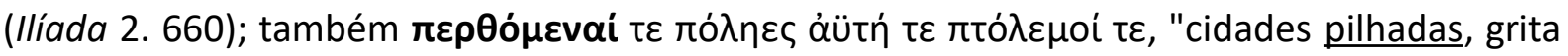
e guerras" (Hino Homérico a Atena 3) ${ }^{20}$ ).

Este mesmo verbo também aparece nos poemas homéricos acompanhado de sufixos

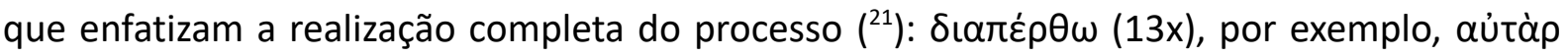

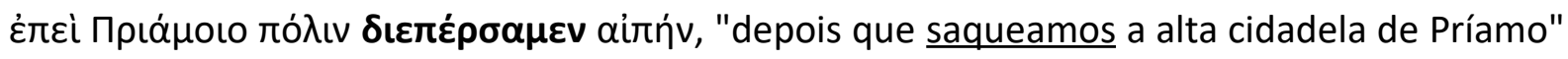

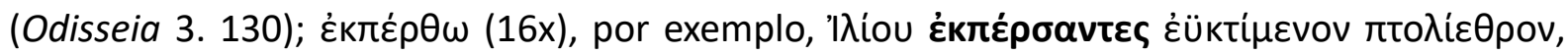
"tendo saqueado a cidade bem habitada de Ílio" (Ilíada 21. 433); na sua forma deverbativa 


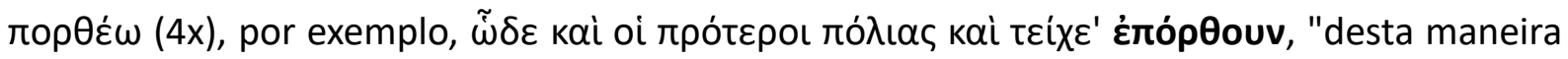
que os antigos destruíram cidades/ e muralhas" (Ilíada 4. 308); e acompanhada de sufixo

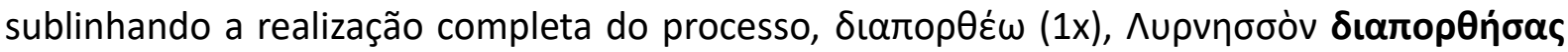

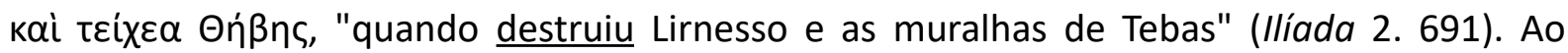

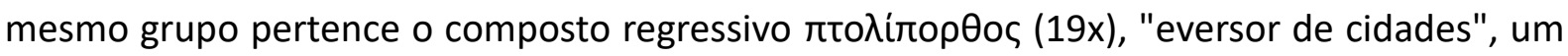
epíteto geralmente encontrado na segunda metade do hexâmetro, nas mais das vezes em companhia dos nomes de Aquiles, Odisseu e Ares. Há também uma contribuição do radical para a onomástica em llíada 14. 115, produzindo o nome próprio e, claramente, nom parlant

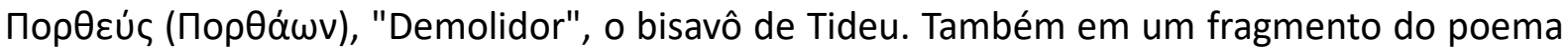

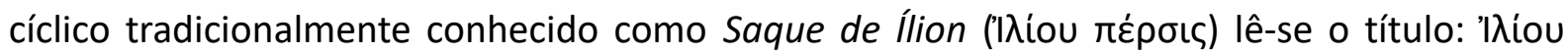
rópӨnбıs, "a destruição de Ílion" (ver frag. 4 Bernabé = 1 Davies = 2 West).

Enquanto $\pi \varepsilon \dot{\rho} \theta \omega$ sempre é usado no mesmo contexto do arrasamento de cidades ou de muralhas, o verbo $\dot{\alpha} \lambda \dot{i} \sigma \kappa o \mu \alpha \iota$ tem na épica grega arcaica um leque semântico bem maior, aparecendo em contextos diferentes, por exemplo: quando um soldado é "capturado" pela

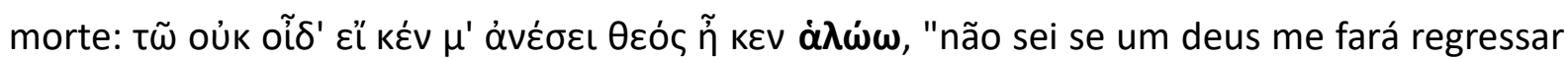
ou se morrerei..." (Odisseia 18. 265); quando é supreendido pelos inimigos: tò dé ṕípıov aï

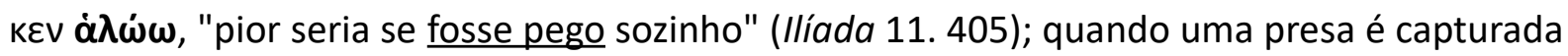

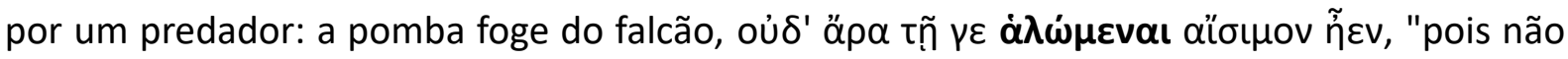
está fadado que seja apanhada" (Ilíada 21. 495); ou capturado em uma rede de caça: $\mu$ ń $\pi \omega \varsigma$

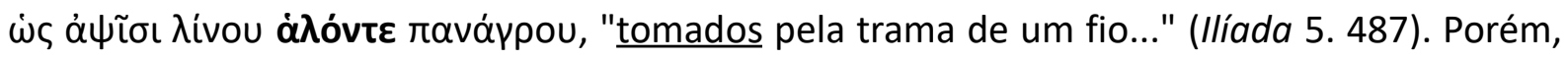
o verbo também aparece ligado a contextos de captura de cidades, como, exempli gratia, em

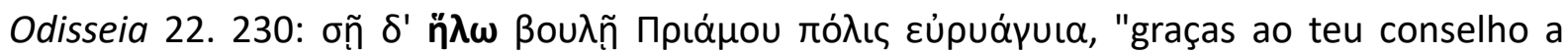

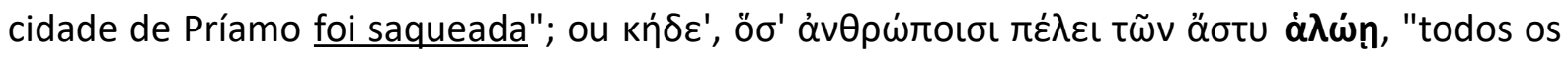
males/ que sovrevêm àqueles cuja cidade é tomada" (Ilíada 9. 592); também encontramos a fórmula importante, que combina $\dot{\alpha} \lambda \dot{i} \sigma \kappa o \mu \alpha \iota$ e $\pi \dot{\varepsilon} \rho \theta \omega$ - de forma muito semelhante àquela

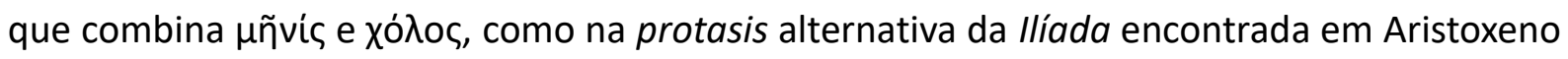

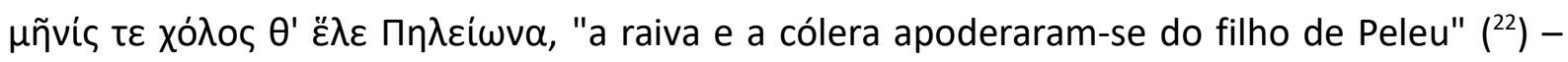

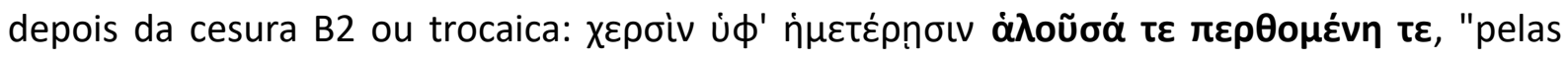
nossas mãos tomada e saqueada" (Ilíada 2. 374; 4. 291; 13. 816).

22 Minha Tradução. 


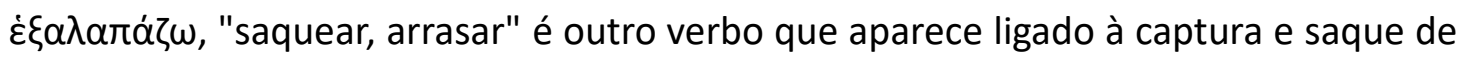
cidade. Suas ocorrências na poesia homérica são bastante regulares: o verbo nas mais das

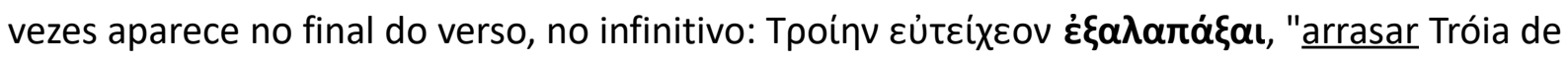
belas muralhas" (Ilíada 8. 241; também 1. 129; 4. 40; 13. 813; Odisséia 3. 85); o verbo ainda

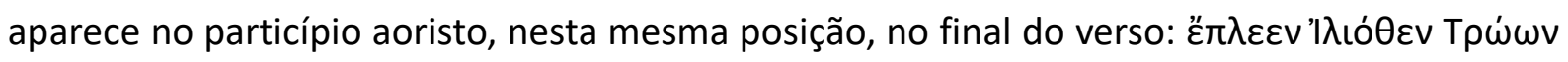
$\pi o ́ \lambda ı v ~ \varepsilon ̇ \xi \alpha \lambda \alpha \pi \alpha \dot{\alpha}\{\varsigma$, "navegou de ílion, tendo saqueado a cidade dos Troianos" (Ilíada 14. 251;

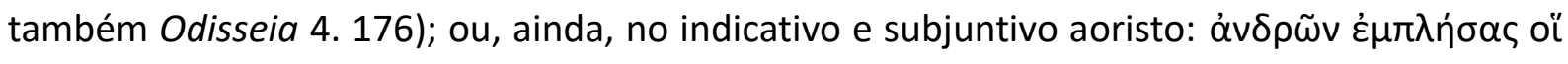

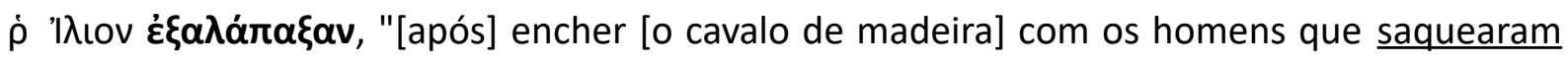

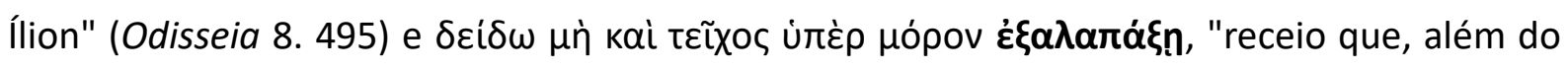
que está destinado, ele arrase a muralha" (Ilíada 20. 30) respectivamente. Nos raros trechos em que o verbo aparece na primeira metade do hexâmetro, ele costuma ocupar o segundo pé, precedido da palavra 'I $\lambda$ íou. Assim aparece em llíada 8. 288 (=4. 33), no infinitivo aoristo:

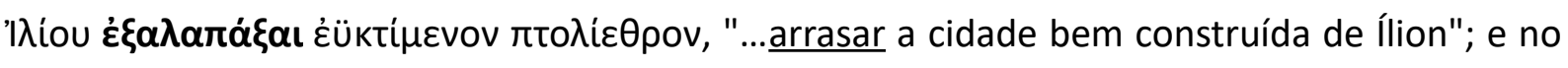

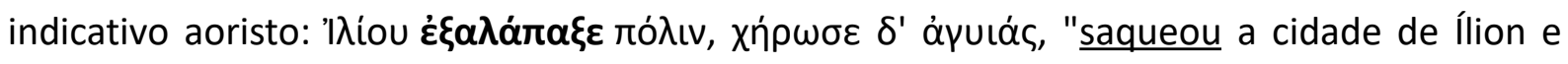
causou desolação nas suas ruas" (Ilíada 5. 642). Em uma passagem, llíada 13. 813, o verbo é utilizado para descrever a destruição das naus dos Aqueus. Isso acontece porque os navios e o acampamento Aqueu são entendidos como a cidade dos Aqueus.

ö $\lambda \lambda u \mu \mathrm{L}$ é mais um verbo empregado para descrever a destruição de uma cidade. Os contextos em que o verbo aparece em épica homérica são, contudo, mais amplos, podendo

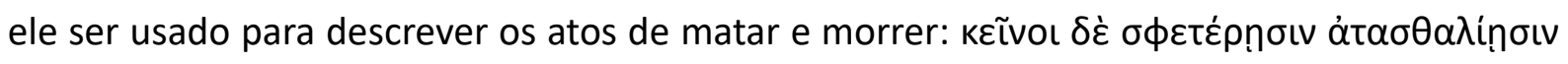

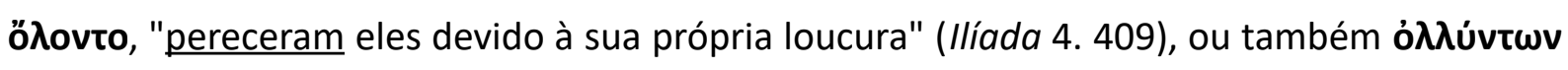

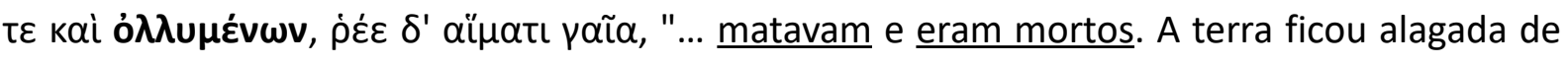
sangue" (llíada 4. 451); ou usado, na linguagem especial da épica homérica, para descrever a

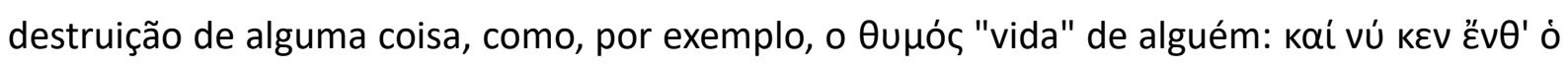

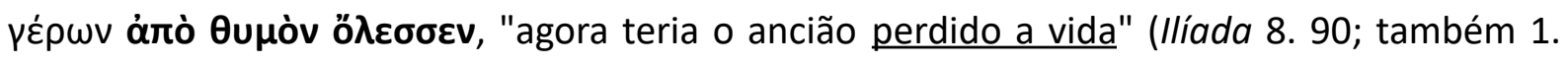

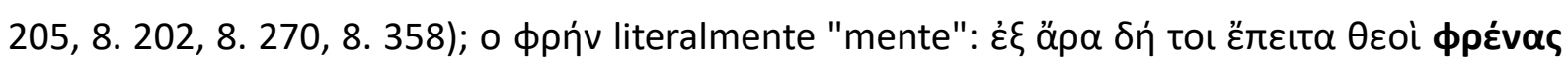

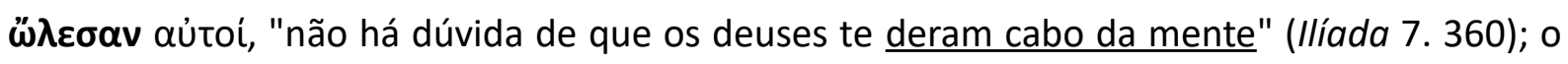

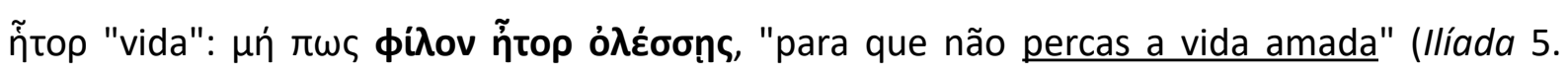

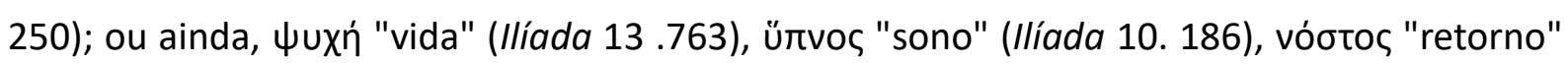

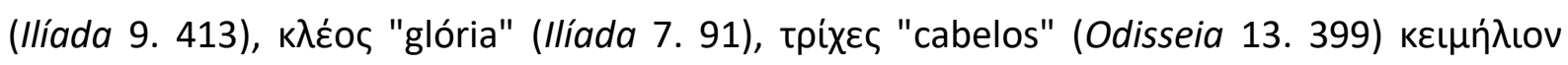




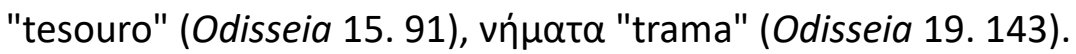

Entre esses encontra-se a destruição de uma cidade, como na expressão de desejo:

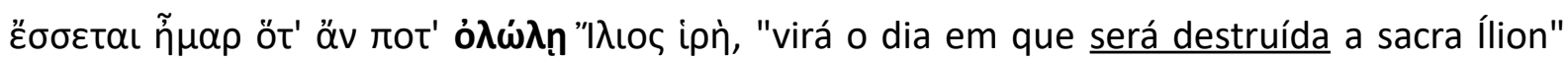
(Ilíada 4. 164 = 6. 448); ou na segunda metade do hexâmetro, também referindo-se à Troia:

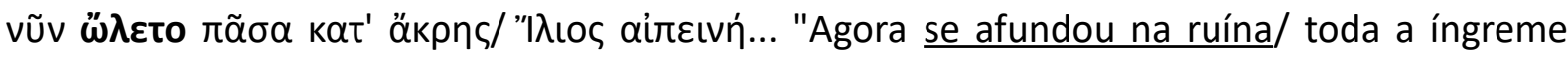
Ílion!" (Ilíada 13. 772-773); também encontra-se registrado o uso do verbo no particípio

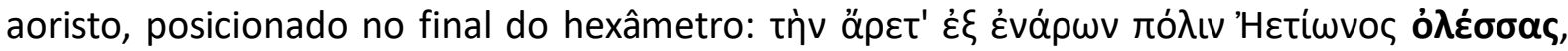

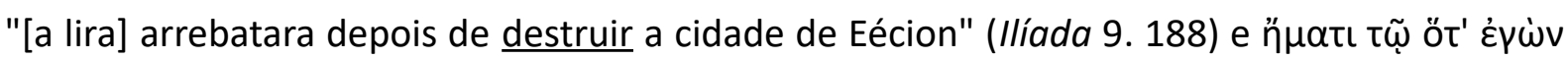

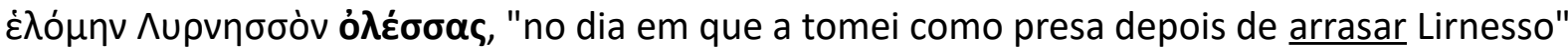
(Ilíada 19.60), uma possível fórmula que une nome da cidade no acusativo ou simplesmente

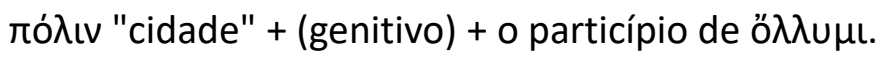

A linguagem especial da épica hexamétrica arcaica conhece ainda outro verbo para expressar a captura e arrasamento de uma cidade: aipéw "pegar, segurar, capturar". O verbo, na tradição posterior, criou compostos tais como aipnoıteíxns "saqueador de cidades", título de uma peça de Dífilo. Como é presumível, ele é bastante produtivo nos textos homéricos e

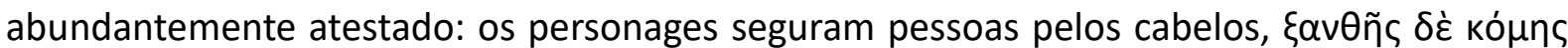

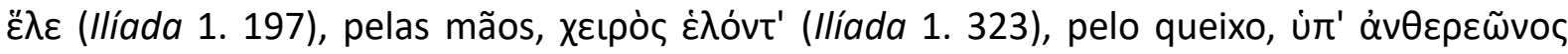

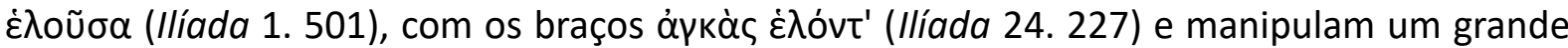
número de objetos: tomam nas mãos, armaduras, lanças, arcos e flechas, escudos, pedras, pães, roupas, presentes, prêmios, caldeirões, tamboretes, capacetes, bois, chicotes, chaves, cadeiras, cajados, cálices, rédeas, e são tomados pelo espanto, medo, terror, sono, saudade, raiva, amor, empatia. O verbo pode ser usado metaforicamente para expressar a ideia de que

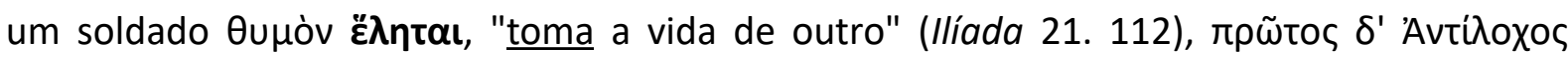

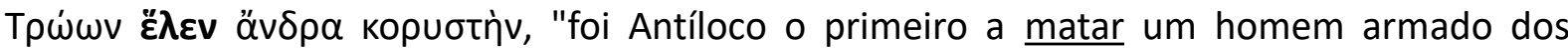

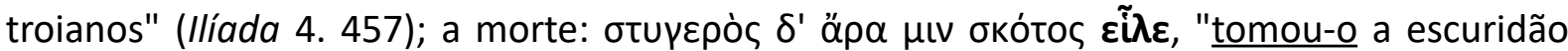

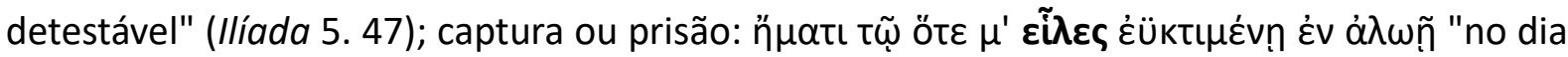
em que me tomaste no bem cuidado pomar" (Ilíada 21. 77); ou simplesmente, um ato como

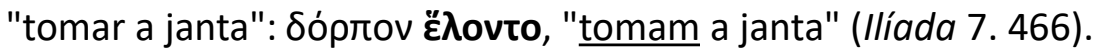

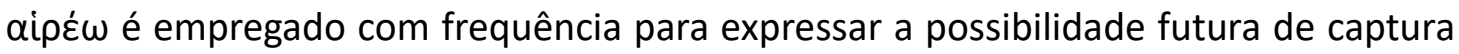

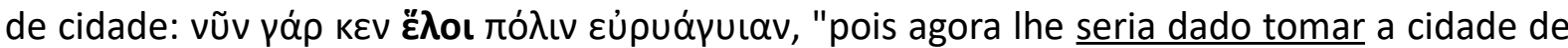




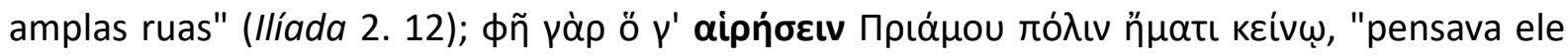

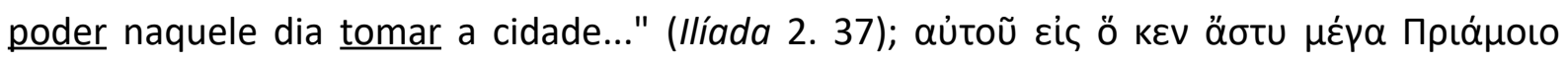

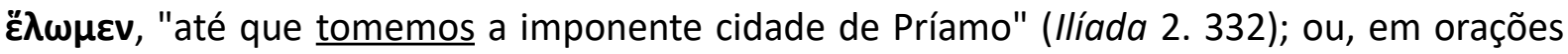

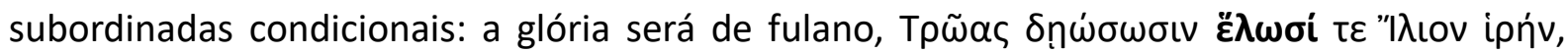
"[se porventura] chacinarem os Troianos e tomarem a sacra ílion" (Ilíada 4. 416); ou ainda,

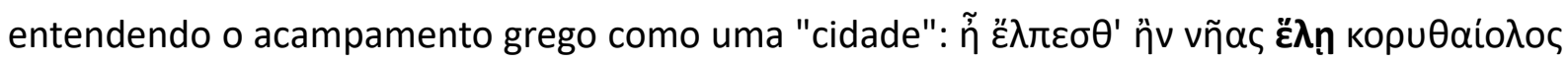

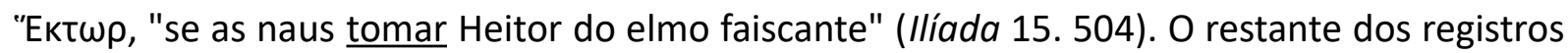
do verbo aipé $\omega$, quando empregado neste sentido, ocorre em menções à captura e saque de

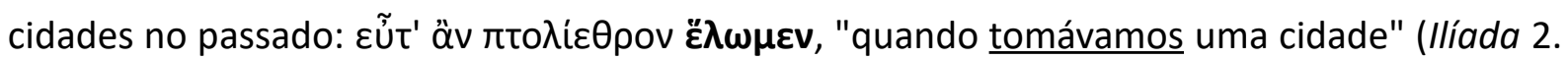

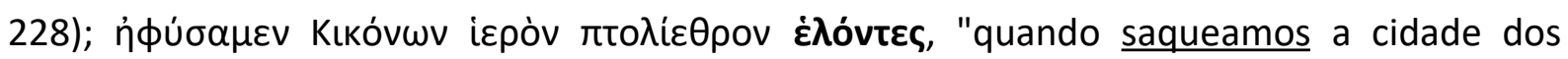
Cícones" (Odisseia 9. 165); ท் da heptápila Tebas" (Ilíada 4. 406); ou na expressão de desejo contrafactual ou irrealizável, também fazendo referência ao passado: prouvera eu tivesse a força oĩos Nńpıkov عĩ்ov,

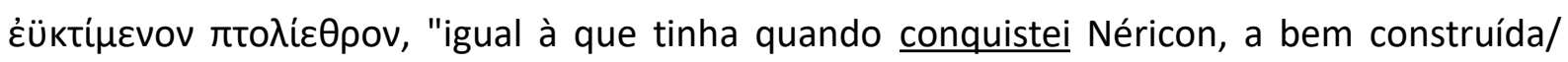
cidade" (Odisseia 24. 377).

Às vezes para exprimir a conquista de uma cidade utiliza-se uma metáfora, como é o caso do verbo n் $\mu$ úw "vergar", "dobrar". O verbo é empregado nos poemas homéricos para descrever o efeito do vento movendo uma plantação de milho e vergando as espigas: $\lambda \dot{\alpha} \beta \rho \circ$

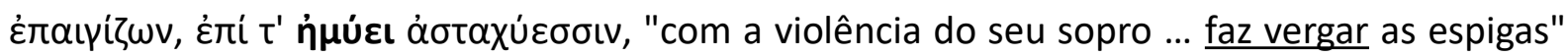
(Ilíada 2. 148); o vergar das espigas serve de compação ao movimento da massa de soldados

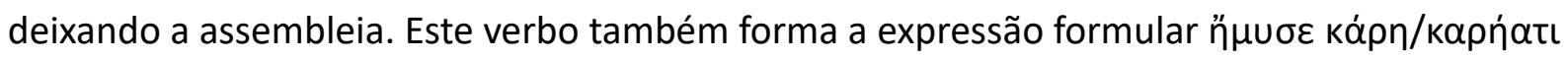
"curvar a cabeça", "inclinar a cabeça", usada para descrever, em comparação, o balanço da cabeça frouxa de um soldado morto por um flechaço, bem como a papoula sobre a qual

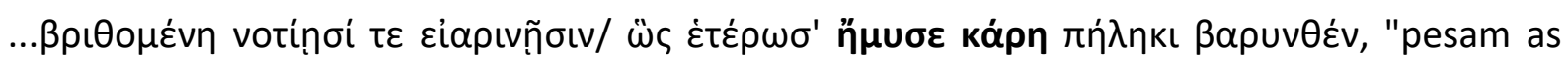
sementes e as chuvas da primavera/ assim inclinou a cabeça pesada devido ao elmo" (Ilíada

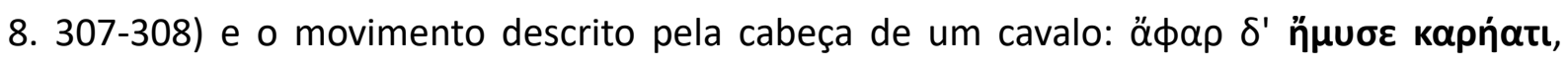
$\pi \tilde{a} \sigma \alpha \delta \varepsilon \dot{\varepsilon} \chi \alpha i t \eta$, "de repente baixara a cabeça e toda a crina caía" (Ilíada 19. 405). Além disso, o verbo n் $\mu u ́ \omega$ também é empregue em expressões do tipo "se tais e tais condições forem cumpridas, então...", exprimindo metaforicamente a sujeição de uma cidade ao inimigo: $\tau \dot{\omega}$

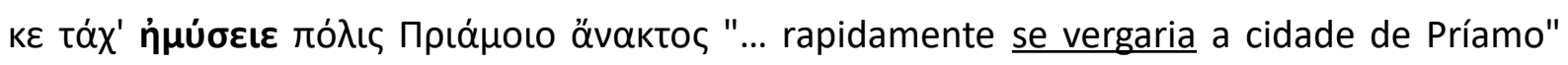


(llíada 2. $373=4.290)$.

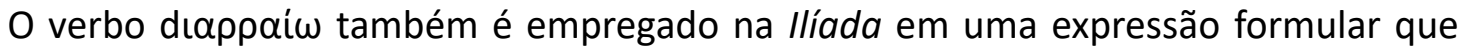
descreve muito mais a intenção do que a efetiva destruição de uma cidade. Trata-se de jaí $\omega$, cujo significado pode ser traduzido como "despedaçar", "destruir", "esmagar". Entre os seus

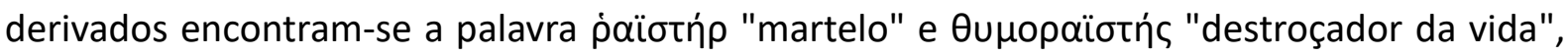
adjetivo da morte (Өávatos) na llíada (13. 544, 16. 414, 16. 580). O verbo pode sempre ser encontrado com o prefixo $\delta\llcorner\alpha-$, que sublinha a realização completa do processo. Ele é usado uma vez para designar a destruição completa (ou não) do exército com a chegada da noite:

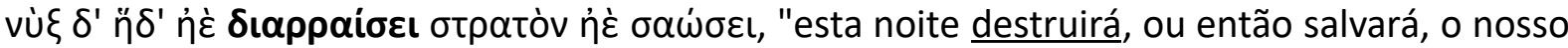

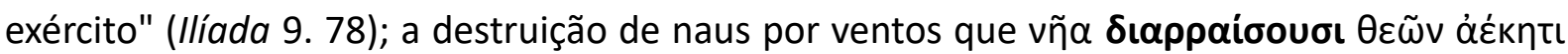
ávóktwv, "despedaçam mais naus à revelia dos deuses soberanos" (Odisseia 12. 290). O

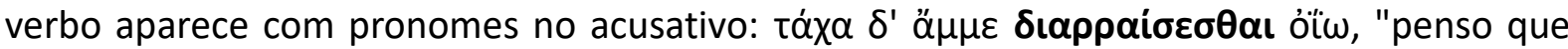

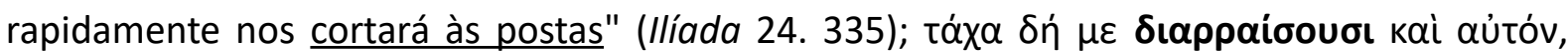
"rapidamente serei eu quem levarão à ruína" (Odisseia 1. 251). Entretanto, o seu emprego

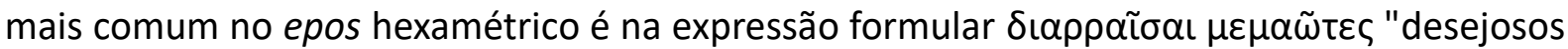
de despedaçar, destruir, esmagar". Esta expressão ocorre em uma cena de caça e descreve o

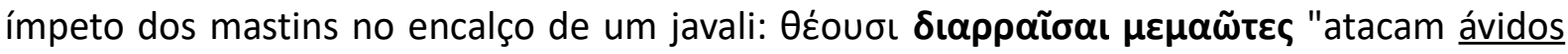
de dilacerarem o javali" (Ilíada 17. 727); e descreve o ânimo dos aqueus após a assembleia

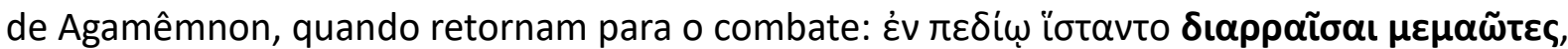
"posicionados na planície desejosos de desmembrar [os Troianos]". Finalmente, a fórmula é

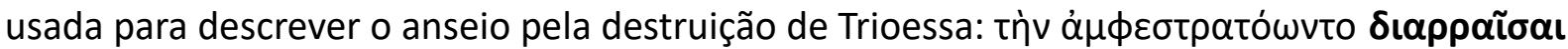
$\mu \varepsilon \mu \alpha \tilde{\omega} \tau \varepsilon \varsigma$, "em roda dela acamparam, ávidos de a arrasarem por completo" (Ilíada 11. 713);

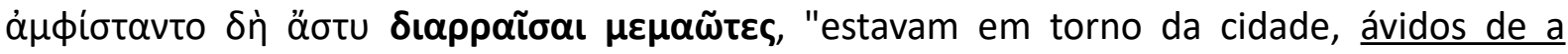
arrassarem por completo" (llíada 11. 733).

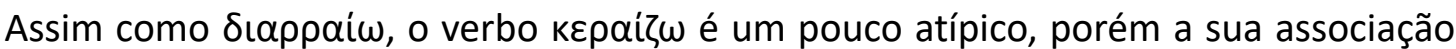
com o tema da captura e destruição de cidades é mais evidente e bem estabelecida. Das oito ocorrências, duas estão em cenas da caça, duas em chacinas e quatro estão relacionadas ao

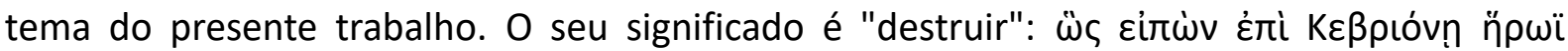

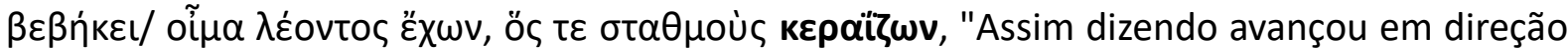
ao herói Cebríones/ com a fúria do leão que quando [dizimava] o estábulo..." (Ilíada 16. 751- 


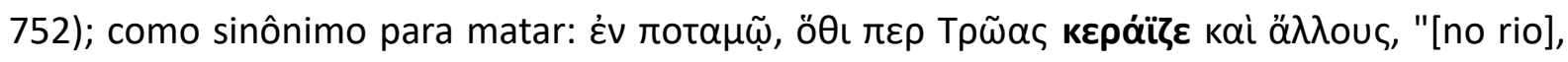
quando dizimava Troianos e também outros" (Ilíada 2. 861). Em um verso, o particípio parece precisar melhor o tipo de destruição provocada, a perda de vidas humanas, depois da cesura

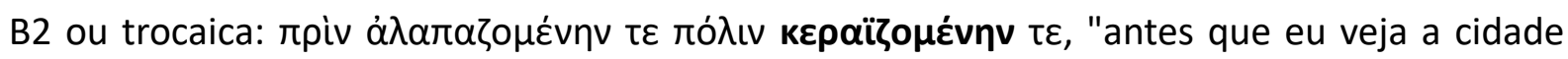
saqueada e destruída" (Ilíada 24. 245); na descrição do arrasamento de Troia: ä $\lambda \lambda$ ov $\delta^{\prime}$ ä $\lambda \lambda n$

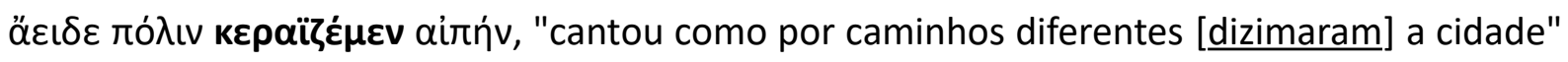

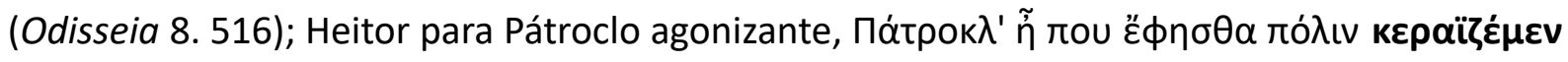

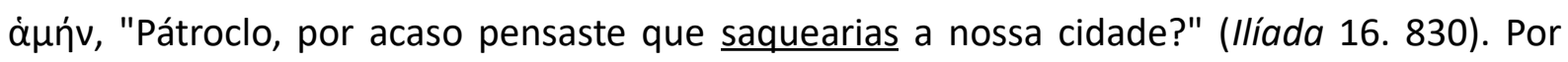

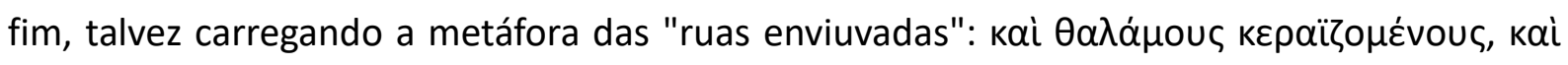

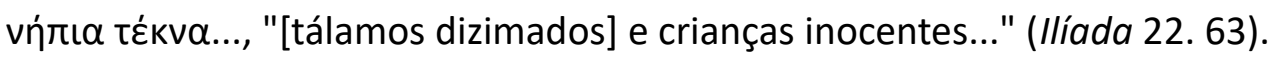

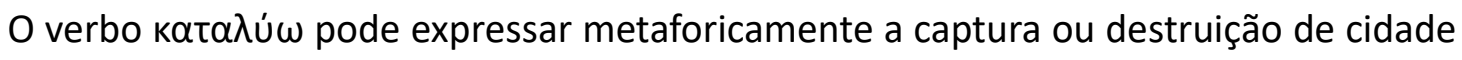

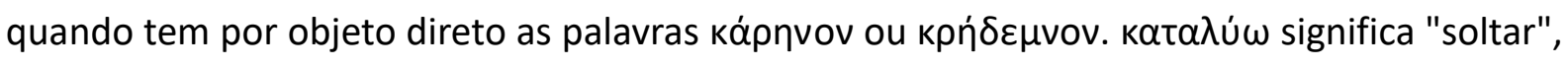

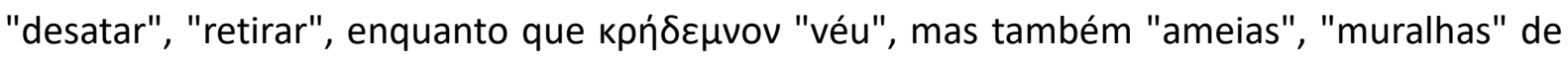
uma cidade. Nesta metáfora, uma cidade saqueada é vista como uma mulher estuprada, que teve o véu retirado (à força) por invasores, uma vez que o véu é um símbolo da "decência",

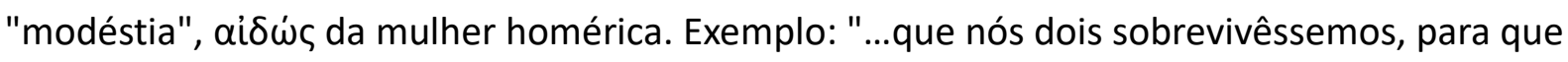

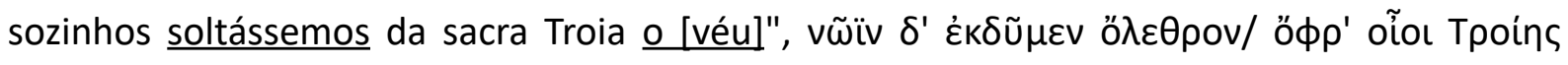

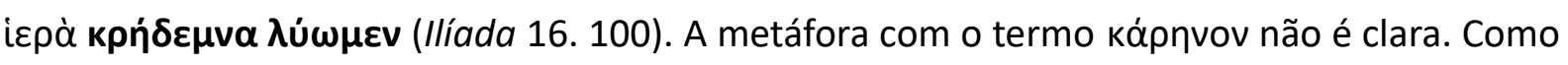
a palavra significa "cabeça", "topo", e talvez até mesmo seja usada para descrever adereços para cabelos, a metáfora pode envolver uma ideia próxima de "cortar cabeças", por exemplo:

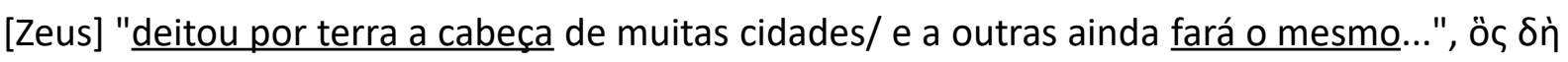

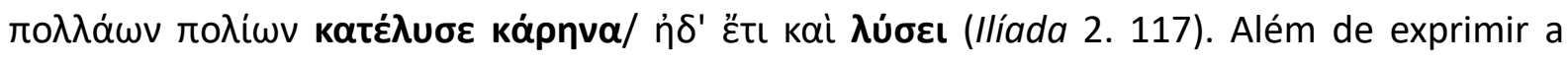
destruição de uma cidade metaforicamente mediante a decapitação, não se pode descartar a possibilidade de que essa expressão detenha aquele mesmo conteúdo da construção com

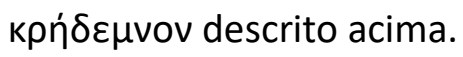




\section{A GLÓRIA}

\subsection{TROIA 1.0}

A llíada relata, em duas brevíssimas narrativas, o arrasamento de Troia pelas mãos de Héracles. A mais longa dessas passagens se acha em 5. 633-654, nas provocações anteriores ao combate singular entre Tlepólemo, filho de Héracles, e Sarpédon, filho de Zeus. A alusão ao episódio surge no centro de um discurso de desafio proferido por Tlepólemo (llíada 5. 3842) e nos versos iniciais da resposta de Sarpédon (vv. 49-51). Para desqualificar o oponente, Tlepólemo sugere que as suas habilidades marciais ficam aquém das de seus ancestrais. Para

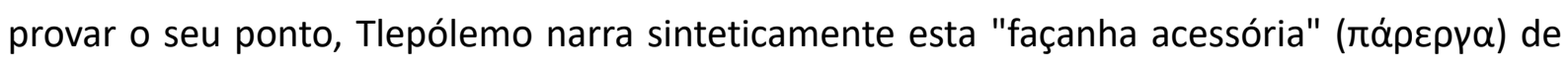
Héracles que é, também como Sarpédon, filho de Zeus. Além disso, a narração deste evento permite a Tlepólemo vangloriar-se da sua própria genealogia, dado que é filho de Héracles. Este episódio, que podemos chamar de Primeira Guerra de Troia, é o seguimento narrativo de um evento mitológico conhecido pela llíada: a construção do extraordinário sistema de muralhas da cidade troiana por Poseidon e Apolo (em Ilíada 21. 442-460, só Poseidon; em 7. 453 ambos o constroem).

O narrador não informa a razão pela qual os deuses desempenham semelhante tarefa para Laomedonte. Segundo RICHARDSON (1993, p. 91), os escólios sugerem que Poseidon e Apolo ficaram encarregados dela como punição por rebelarem-se contra Zeus, uma espécie de condenação a trabalhos forçados, embora Laomedonte tenha prometido compensação

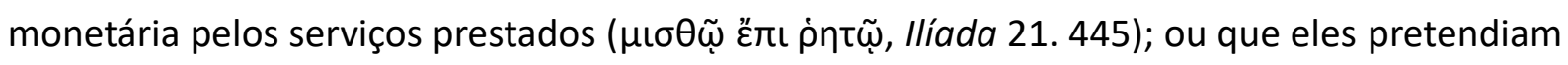
colocá-lo a prova, como em uma "teoxenia" (Apolodoro, Biblioteca 2.5.9; Helânico 4.26a) $\left({ }^{23}\right.$ ). Seja como for, ambos os deuses atuaram durante um ano sob a supervisão de Laomedonte,

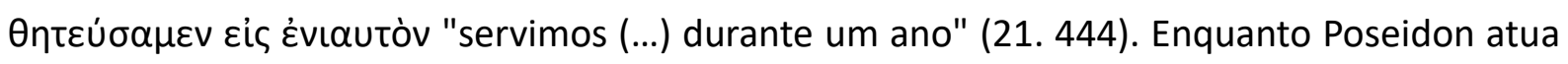
na edificação das muralhas da cidade: "construí para os troianos a muralha em torno da

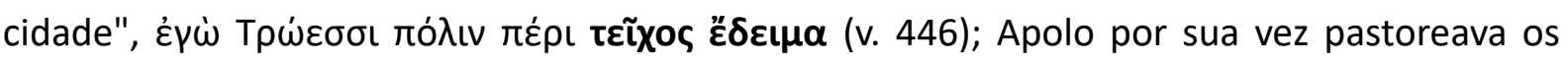

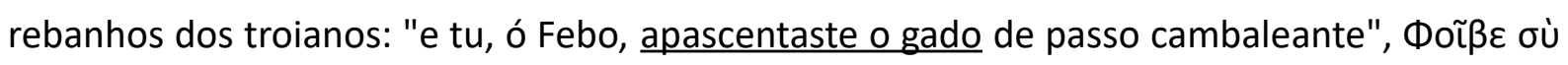

23 Sobre o conceito de "teoxenia" ver LOUDEN (2011a, pp. 30-56) e (2011b, pp. 867-868). 


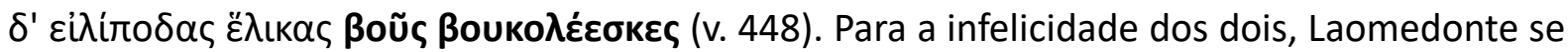
revela um trickster e descumpre o acordo, de modo que Poseidon e Apolo retornam de mãos

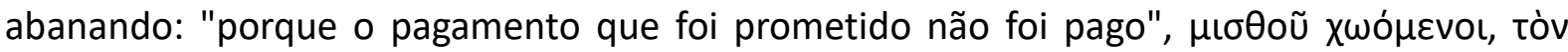

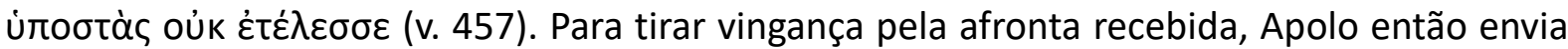
à cidade uma peste $\left({ }^{24}\right)$ e Poseidon um monstro marinho, mencionado em Ilíada 20. 145-148 e 15. 18-33.

É nesta altura da narrativa que Héracles entre em cena. De acordo com um fragmento de Helânico (4.26b) preservado no comentário parafrástico de um escoliasta ad llíada 5. 649, Laomedonte descobre por meio de um oráculo que para se livrar da ameaça marinha deve entregar sua filha, Hesíone, ao monstro. Assim ele faz. Entretanto, também promete entregar os seus cavalos divinos como recompensa àquele que a salvasse (Ilíada 5. 265-270, 23. 348). Os troianos, auxiliados por Palas Atena, constroem uma fortificação de onde Héracles estaria capacitado a enfrentar o monstro (кñтoৎ): "a muralha amontoada do divino Héracles ... para

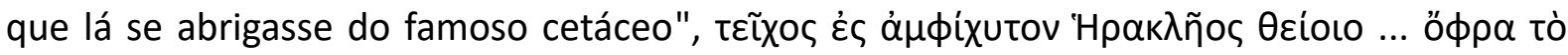

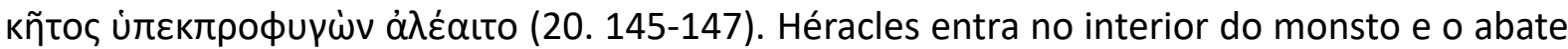
de fora para dentro, salvando assim a princesa Hesíone (Helânico 4.26b). Laomedonte, pela segunda vez nesta história, descumpre as suas promessas, pelo que Héracles arrasa a cidade $\left.{ }^{(25}\right)$. Eis o trecho; llíada 5. 633-651:

\begin{tabular}{|c|c|}
\hline & 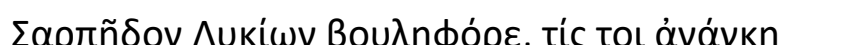 \\
\hline 635 & 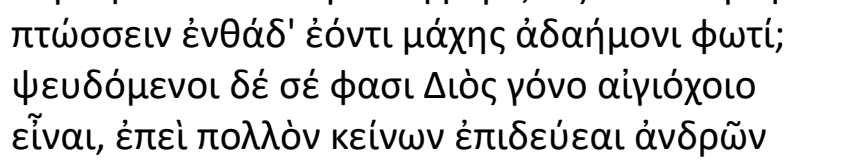 \\
\hline & 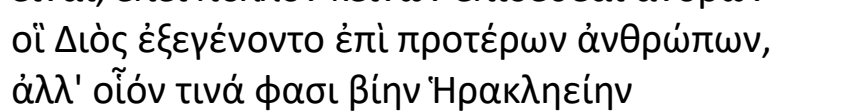 \\
\hline 640 & 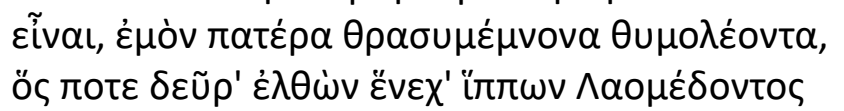 \\
\hline & 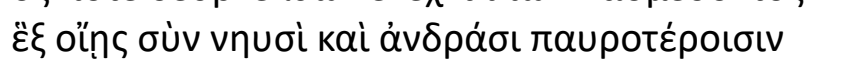 \\
\hline & 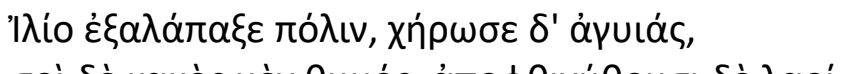 \\
\hline & 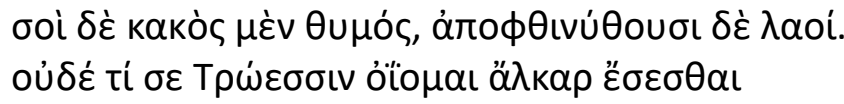 \\
\hline 645 & 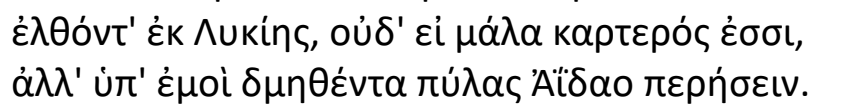 \\
\hline
\end{tabular}

24 Ver. RICHARDSON (1993. p. 91).

25 Para mais detalhes desta história, ver STAFFORD (2012, pp. 70-72) e GANTZ (1993, pp. 400-402). 


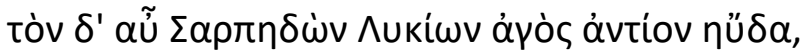

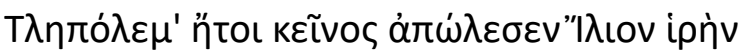

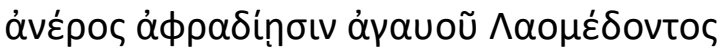

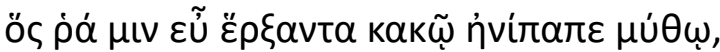

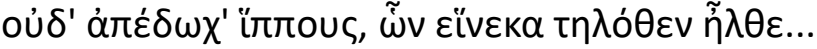

'Sarpédon, conselheiro dos Lícios, por que te vês obrigado a andar para ai encolhido, homem inexperiente em combate? Mentem os que te proclamam filho de Zeus detentor da égide, visto que és muito inferior àqueles varões que dentre os homens antigos foram gerados por Zeus. 'De outra têmpera dizem ter sido a Força de Héracles, meu pai, ousado guerreiro de coração de leão, que outrora aqui veio pelos cavalos de Laomedonte só com seis naus e menor número de homens: saqueou a cidade de Ílion e causou desolação nas suas ruas. Mas o teu coração é de covarde e o teu povo sucumbirá. Não penso que para os troianos serás um baluarte por teres vindo da Lícia, mesmo que fosses mais forte; mas por mim subjugado passarás os portões do Hades'. A ele deu resposta Sarpédon, comandante dos Lícios: 'Tlepólemo, na verdade teu pai arrasou a sacra Ílion, devido aos desvarios daquele homem, o altivo Laomedonte, que repreendeu com palavras àsperas quem bem o servira e não Ihe deu as éguas, pelas quais ele de longe aqui viera...'

Tlepólemo considera Sarpédon inferior aos heróis de sua própria estirpe: oỉ $\Delta$ iò

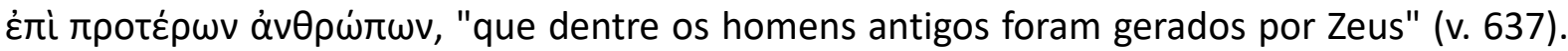
Dentre eles, Héracles, identificado por meio da expressão metonímica "Força de Héracles"

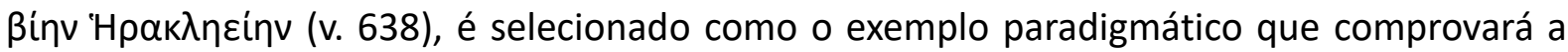
pertinência do argumento e provocação lançada a Sarpédon. A menção a Héracles introduz a

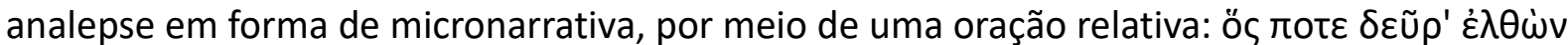

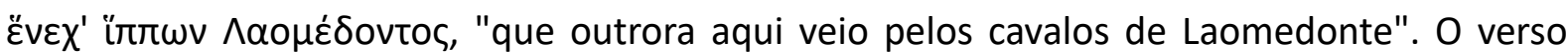
subsequente descreve sumariamente o deslocamento de Héracles para Troia, porém é difícil

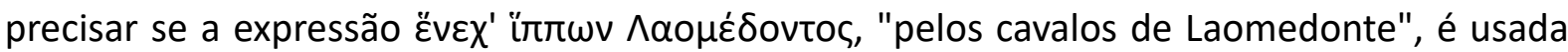
para designar apenas o motivo do deslocamento do herói ou também o do arrasamento da cidade. Se esse for o caso, teríamos topado pela primeira vez, nesta passagem, com a causa da destruição de uma cidade explicitada. Na resposta dada por Sarpédon, o motivo do saque 
é externado categoricamente: "[Héracles] arrasou a sacra Ílion/ devido aos desvarios daquele

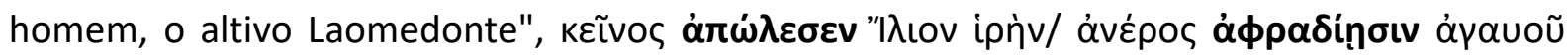

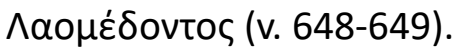

Sarpédon atribui a destruição de Troia a uma certa conduta que ele descreve como

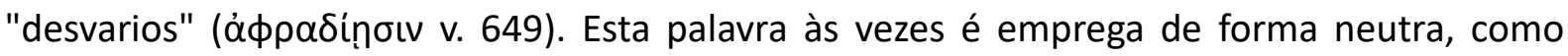
quando Dólon acaba inadvertidamente emboscado por Odisseu e Diomedes (Ilíada 10. 350).

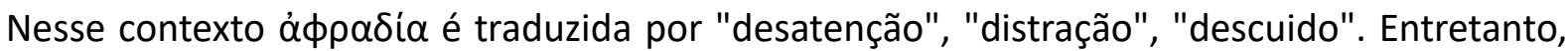
em outros contextos, o termo pode ter uma conotação negativa de "desvario", "disparate", como que carregando uma censura $\left({ }^{26}\right)$. Encontramos o segundo sentido em Odisseia 10. 1927. Aqui Éolo dá um presente a Odisseu: "deu-me um saco feito da pele de um boi de nove

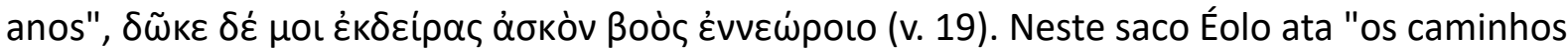
dos ventos turbulentos" e, mais adiante, faz bater o Zéfiro, "para que levasse à sua frente as

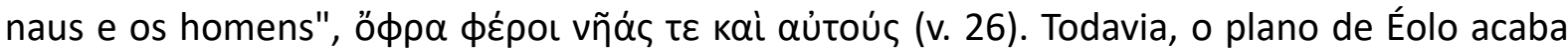
frustrado porque os companheiros de Odisseu abrem o saco e deixam os ventos escaparem.

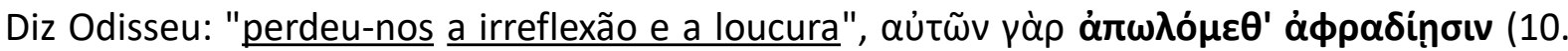

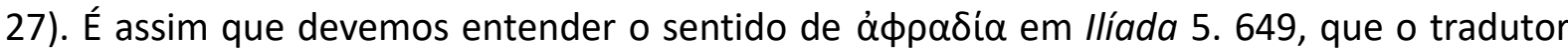
Frederico Lourenço verte por dois termos: irreflexão e loucura. Troia é destruída por causa da

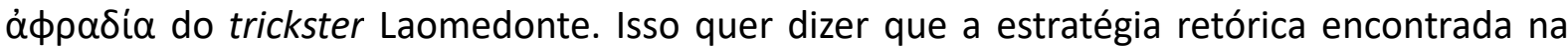
resposta de Sarpédon consiste em reduzir a importância de Héracles e estabelecer um novo nexo de causalidade que implica Laomedonte e o apresenta como o maior, senão o único, responsável pelo arrasamento da cidade.

A conduta de Laomendonte ainda é mais especificamente descrita por Sarpédon no

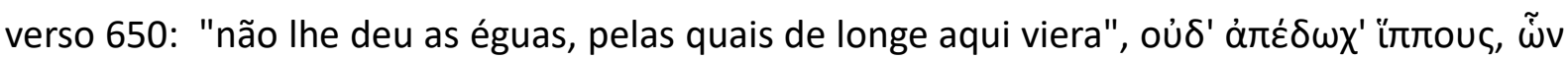

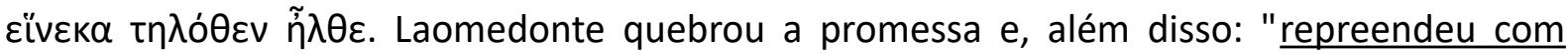

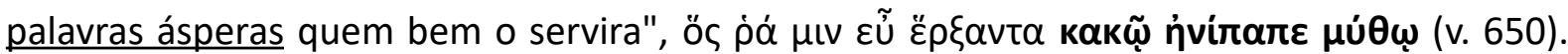
Sarpédon acusa a quebra das regras de hospitalidade da parte de Laomedonte e semelhante

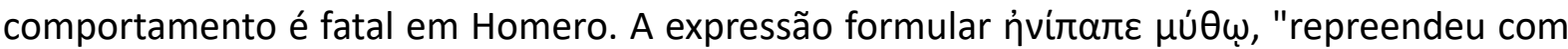
palavras", apenas nesta passagem do corpus não é utilizada para introduzir um discurso de repreensão (Ilíada 3. 427; Odisseia 20. 17; 20. 203). Esta repreensão pode algumas vezes ser

26 Cf. Ilíada 2.368; 5.649; 10.122, 350; 16.354; Odisseia 9.361; 10.27; 17.233; 19.523; 22.288; Trabalhos e Dias 134, 330. DE JONG (2001, p. 418); BARKER \& CHRISTENSEN (2014, p. 265). 


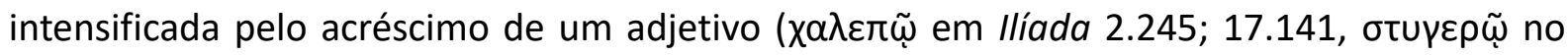
Hino Homérico a Dioniso 25), tal como кakஸ̣ nesta passagem $\left({ }^{27}\right)$. Ademais, a diferença entre as condutas de Hércules e de Laomedonte é frisada pelo contraste entre fazer coisas boas

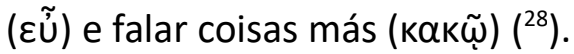

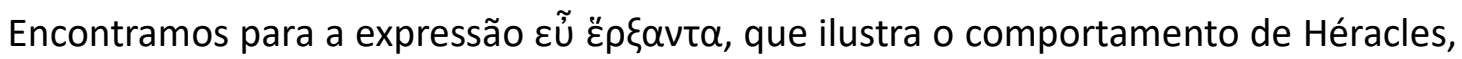
um paralelo negativo em uma prece realizada por Menelau antes do duelo ritual contra Páris Alexandre em Ilíada 3. 313-82. Menelau pede a Zeus "reparação" (tíoıs) pelos crimes praticados pelo troiano: "Zeus soberano, concede que me vingue de quem errou primeiro",

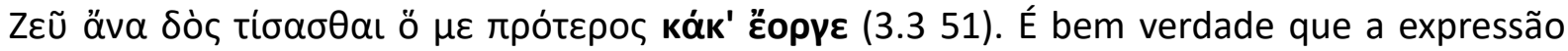

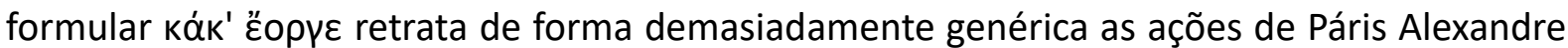
e pode ser aplicada a quaisquer casos de transgressão ou má conduta. Entretanto, o mesmo contexto de violação de regras de hospitalidade chama excepcionalmente a atenção $\left({ }^{29}\right)$. As

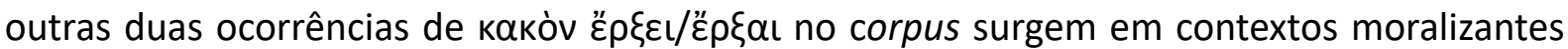

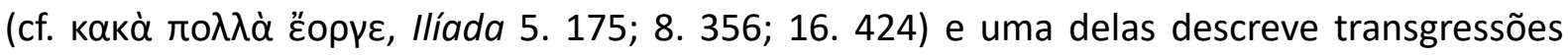
contra estrangeiros e suplicantes: "age igual quem prejudica suplicante ou estranho", ĩoov $\delta^{\prime}$

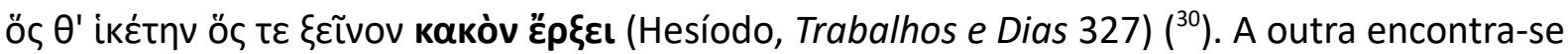
no relato de Antínoo sobre o casamento de Pirítoo. O centauro Eurítion teria bebido em

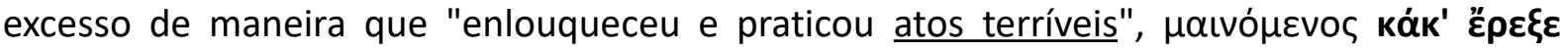

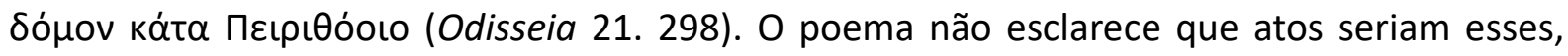
porém, sabemos por outras fontes que o centauro teria assediado mulheres na festa. Esta possibilidade ainda criaria uma simetria entre a Primeira Guerra de Troia e a Segunda, bem ao gosto dos critérios artísticos encontrados nos poemas homéricos $\left({ }^{31}\right)$ e de acordo com a caracterização geral dos troianos na llíada. Na Primeira Guerra o troiano viola as regras de hospitalidade em sua própria casa, enquanto na Segunda um troiano as viola no exterior. O exemplo paradigmático para a primeira forma de transgressão é Polifemo (Odisseia 9. 106566), para a segunda, talvez os centauros (Ilíada 1. 260-273; Odisseia 21. 298).

O discurso de Tlepólemo ainda apresenta outras elementos descritivos da expedição,

27 Ver KRIETER-SPIRO (2015, p. 156).

$28 \operatorname{KIRK}(1990$, p. 124).

29 LOUDEN (2006, p. 193).

30 Tradução de WERNER (2013).

31 SCHEIN (1997, pp. 345-349). 
como a referência ao tamanho do exército envolvido na tomada da cidade, "só com seis naus

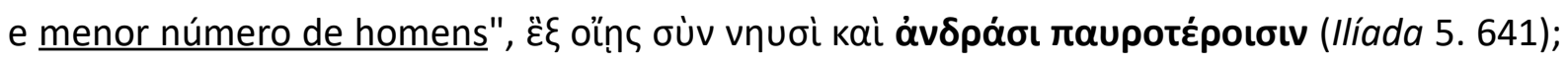
o que também recebe menção no relato sobre a destruição da cidade de Tebas, em contraste com o contingente levado para a Segunda Guerra de Troia $\left({ }^{32}\right)$. A utilização de um dos verbos

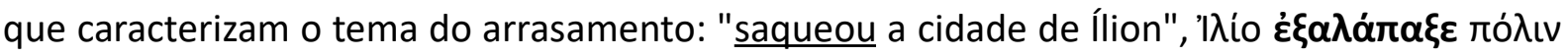
(v. 642), também está presente na resposta de Sarpédon, "arrasou a sacra Ílion", ả

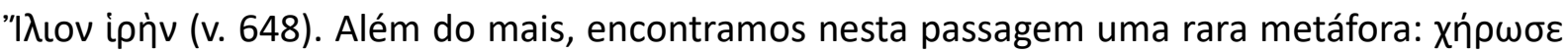

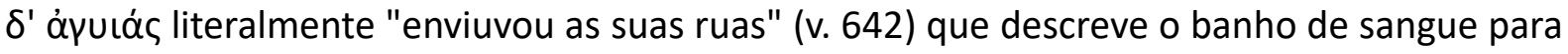
os homens da cidade e, ao mesmo tempo, faz referência à devastação associando-os à figura feminina $\left({ }^{33}\right)$.

A destruição da cidade por Héracles na Primeira Guerra de Troia também é citada, em outra passagem, muito brevemente, pela divindade do Sono em uma discussão com Hera. A deusa tenta persuadi-lo a enfeitiçar a mente de Zeus, mas Sono explica que com Zeus não se atreveria a mexer, narrando um episódio em que, para prejudicar Héracles, que retornava do saque, quase foi punido. Assim, Sono diz que os planos de Hera já o lesaram anteriormente, "no dia em que aquele magnânimo filho de Zeus, navegou de ílion, tendo saqueado a cidade

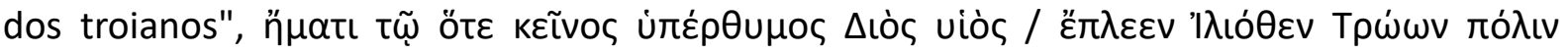

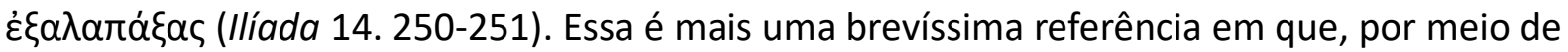
oração temporal, retoma-se um evento passado. A ação principal e o foco dessa narrativa concentram-se no regresso do herói por mar (ع̋ $\lambda \varepsilon \varepsilon \varepsilon v ~ v . ~ 250)$, retornando de Troia - porque é neste contexto que ele será então prejudicado por Hera. A alusão à destruição da cidade,

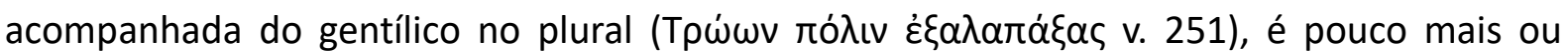
menos acessória, oferecendo um enquadramento temporal maior para a ação principal.

\subsection{TEBAS DAS SETE PORTAS}

A cidade de Tebas é a sede do chamado Ciclo Tebano, que compreende ao menos três poemas épicos, que narram a história de três gerações de tebanos. O Ciclo Tebano centra-se

32 Infra, p. 51 e p. 82.

33 ANDERSON (1997, p. 93, n.1) também considera a possibilidade de alusão ao regicídio de Laomedonte. Ver VERMEULE (1987, p. 130), HAUBOLD (2005, p. 95), sobre a rivalidade entre as narrativas acerca de Héracles e o poema da Ilíada. 
sobretudo em narrativas de desavença familiar, conflitos bélicos e duas expedições militares dos argivos com o objetivo de saquear e arrasar a cidade. O primeiro poema deste conjunto,

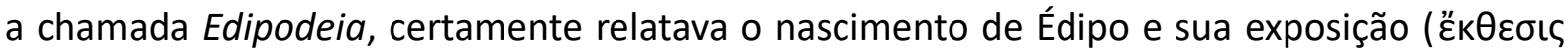
ou áró $\theta \varepsilon \sigma \iota \varsigma) ~\left({ }^{34}\right)$ no monte Citéron com os pés amarrados. Nossas fontes ignoram a função do oráculo de Delfos e do vidente Tirésias na narrativa, entretanto o poema provavelmente abordava a profecia revelada a Laio de que o seu filho seria a razão de sua ruína. De acordo com CINGANO (2015a, p. 216), a Edipodeia indubitavelmente narrava o parricídio de Laio na encruzilhada, a vitória e morte (ou suicídio) subsequente da Esfinge, que caçava com voracidade predatória os habitantes da cidade a partir de uma montanha nas proximidades; o consequente casamento com a própria mãe, Jocasta/Epicasta (Odisseia 11. 271; schol. ad Eurípides, Fenícias 13; Apolodoro, Biblioteca 3.5.7); e ascensão ao trono tebano $\left({ }^{35}\right)$. Jocasta se suicidava, Édipo casava-se uma segunda vez, gerando assim Etéocles, Polinices, Ismene e Antígone. Não se sabe se o poema terminava com a celebração de jogos fúnebres em honra de Édipo ou se o poema se prolongava para incluir também o episódio da desavença entre os irmãos Etéocles e Polinices $\left({ }^{36}\right)$.

O relato encontrado em Apolodoro (Biblioteca 3.5.7-3.7.1) segue de perto a Tebaida: Depois de arrancar seus olhos, Édipo procura o exílio e lança uma maldição sobre seus filhos. Assim, Etéocles e Polinices firmam um acordo sobre a governança de Tebas: decidem-se por revezar no poder em períodos de um ano (Biblioteca 3.6.1). Apolodoro chama a atenção para o fato de as narrativas apresentarem, nesta altura, variações: algumas delas registram que Polinices reinou em primeiro lugar e que, transcorrido o período acertado, entregou o poder a Etéocles; enquanto outras contam que Etéocles foi o primeiro a governar a cidade e que, quando passou um ano, recusou-se a transferir as funções monárquicas ao irmão $\left({ }^{37}\right)$. Uma vez banido de Tebas, Polinices busca ajuda em Argos, levando consigo o colar e o peplo de Harmonia $\left({ }^{38}\right)$. Ele chega ao palácio real, encontra Tideu, filho de Eneu e os dois iniciam uma briga. Adrasto, o rei de Argos, vê a confusão e a compreende à luz de um oráculo de Apolo, que Ihe recomendava casar as duas filhas, Árgia e Deípile, com um leão e um javali, por acaso

Ver HUYS (1989).

CINGANO (2015, p. 216).

CINGANO $(2015$, p. 217).

CABRAL (2013, p. 102, n. 70).

38 Ver GANTZ (1993, pp. 471-472) sobre esses objetos. 
os animais representados nos escudos de Polinices e Tideu, respectivamente. Assim, Adrasto promove o casamento de suas filhas e promete restabelecer ambos os guerreiros em suas cidades (Tideu era exilado de Cálidon).

Primeiramente, Adrasto organiza uma expedição contra a cidade de Tebas e convoca sete comandantes, cujos nomes variam dentro da tradição. Um desses, Anfiarau, vidente e soldado, não se deixa convencer facilmente, pois augurava a morte de todos, excetuando Adrasto, e a destruição do exército; mas acaba sendo persuadido no final (Biblioteca 3.6.2).

Formado o exército, declara-se guerra e marcha-se contra Tebas. Em busca de água as tropas estacionam em Nemeia. Lá encontram Hipsipile, que abandona o bebê de que estava cuidando para guiar as tropas até uma fonte de água. Quando retornam, descobrem que o bebê foi morto por uma serpente. Anfiarau interpreta este evento como um sinal divino que prefigura o destino de morte e o fracasso da expedição. Em honra do bebê são instituídos e disputados pela primeira vez os jogos de Nemeia (Biblioteca 3.6.4).

Então o exército chega ao monte Citéron e envia uma embaixada, encabeçada pelo herói Tideu, solicitando que Etéocles entregue o trono a Polinices. A embaixada fracassa e a guerra eclode: os sete comandantes dos argivos se posicionam diante de cada uma das sete portas da cidade. Etéocles, por sua vez, prepara os cadmeus para o combate: primeiramente, ele aponta o mesmo número de comandantes para defender cada uma das portas de Tebas. Em segundo lugar, ele consulta Tirésias para saber como conseguir a vitória. $\mathrm{O}$ advinho revela que os tebanos teriam a vitória se por acaso Meneceu, um dos filhos de Creonte, entregasse a sua vida a Ares. Ao ouvir o oráculo, Meneceu degola a si mesmo diante dos portões e do inimigo (Biblioteca 3.6.7).

Segundo Apolodoro, o combate primeiramente se desenrola na planície em frente à cidade, após o que os cadmeus são forçados a recuar para o interior das muralhas. Um dos argivos, Capaneu, tenta escalar as fortificações, porém é fulminado por Zeus. Então é a vez dos argivos retrocederem assustados. Em seguida, os exércitos dos argivos e dos cadmeus, de comum acordo, organizam um combate singular entre Etéocles e Polinices. O duelo tem um desfecho sinistro: ambos perdem a vida simultaneamente. Então os demais comandantes argivos vão sendo derrotados um a um, inclusive Tideu. Anfiarau tenta fugir, porém é tragado pela terra. Adrasto consegue escapar em seu cavalo mágico, Árion, e mais tarde obtém a 
permissão dos tebanos para enterrar os seus mortos (Biblioteca 3.6.8).

Alguns dos episódios narrados por Apolodoro na Biblioteca tem correspondência nos poemas homéricos, entretanto, a maioria das referências ao Ciclo Tebano apresentam-se em pequenas notas, sempre muito pontuais como a menção a Adrasto e a sua relação com a

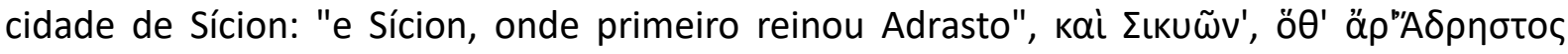
$\pi \rho \tilde{\omega} \tau^{\prime} \varepsilon \dot{\varepsilon} \mu \beta \alpha \sigma i \operatorname{\lambda } \varepsilon \cup \varepsilon v$ (Ilíada 2. 572); à ajuda dispensada a Tideu por Atena: "se alguma vez ao

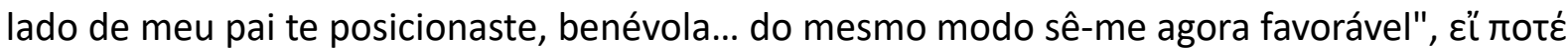

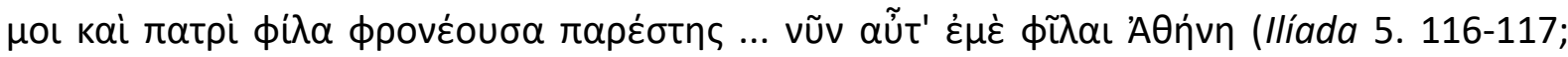

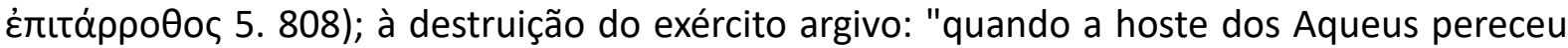

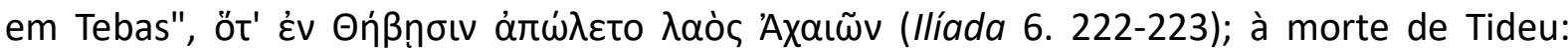

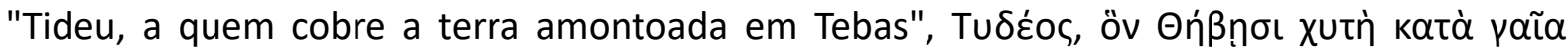

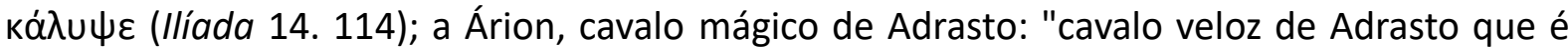

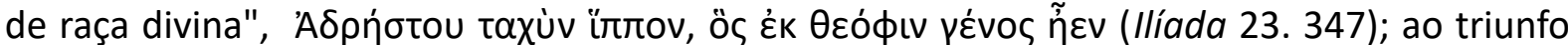
de Mecisteu nos jogos fúnebres celebrados em honra de Édipo em Tebas: "que outrora viera

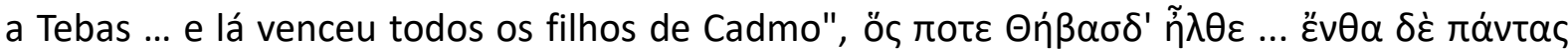

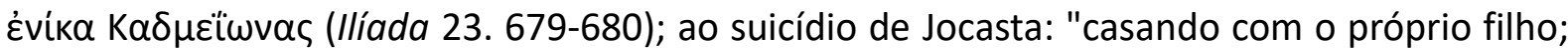

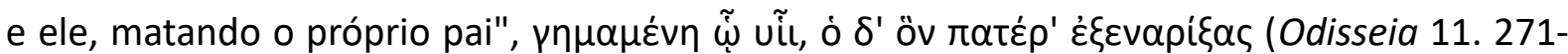
280); às tratativas escusas de Erífile, esposa de Anfiarau: "que recebeu ouro em troca da vida

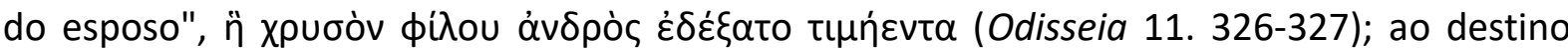
funesto de Anfiarau: "morreu em Tebas, por causa dos dons de uma mulher", $\alpha^{\prime} \lambda \lambda^{\prime}$ ő $\lambda \varepsilon \tau^{\prime}$ ćv

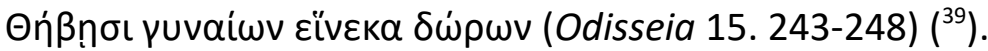

Porém, a llíada cita em três ocasiões, um pouco mais generosamente, dois episódios preliminares à batalha campal e subsequente destruição da expedição na Primeira Guerra de Tebas: a embaixada a Micenas, para arregimentar tropas, e a embaixada a Tebas, um último esforço diplomático para evitar o confronto iminente entre os exércitos. Esses episódios são mencionados em um discurso de batalha, no formato de censura ou de reprovação $\left({ }^{40}\right)$, de

EDWARDS (1992, p. 303); FENIK (1968, pp. 49-52); KIRK (1990, p. 109, 140, 281); JANKO (1992, pp. 162-165).

40 A história é complexa. Segundo Apolodoro, Anfiarau e Adrasto tiveram uma desavença. O vidente, então faz a promessa de que dali em diante a sua esposa julgaria todas as futuras divergências com Adrasto. Uma vez que Adrasto não conseguia convencer Anfiarau a marchar com a hoste na expedição contra Tebas, Polinices entrega o colar de Harmonia à Erífile. Subornada a esposa, Anfiarau é forçado a cumprir sua promessa e a divergência é resolvida. Antes de marchar contra Tebas, entretanto, ele pede aos seus filhos para matarem a mãe e organizarem eles mesmos uma expedição contra Tebas quando crescessem. Cf. Apolodoro, Biblioteca 
Agamêmnon. Há muitos paralelos em llíada 4, em que Agamêmnon é incitado a censurar a indiferença de um soldado para o combate ou às vezes a sua recusa. Citaremos mais adiante o episódio em que Alexandre se depara com Menelau em batalha, tem sua coragem abalada e retrocede para o meio das tropas amigas. Heitor o censura (Ilíada 3. 38). Da mesma forma, Odisseu e suas tropas são repreendidos por Agamêmnon em Ilíada 4. 329-348 por estarem

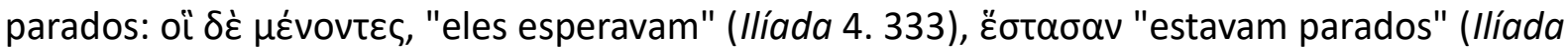
4. 334) $\left({ }^{41}\right)$. A cena que vamos examinar mostra Agamêmnon encontrando Diomedes parado ao lado dos cavalos e o censurando mediante uma comparação desfavorável com Tideu.

O episódio é importante porque a discussão entre Agamêmnon, Diomedes e o filho

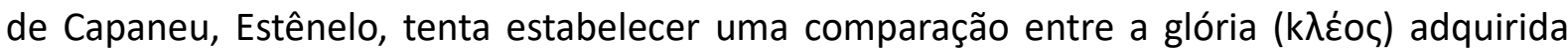
mediante façanhas ( $\varepsilon p \gamma \alpha$ ) atléticas, diplomáticas e bélicas e a mediante o saque de cidades

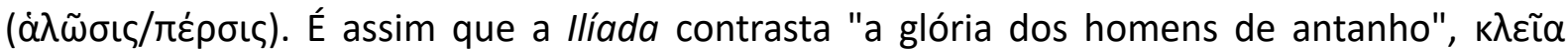

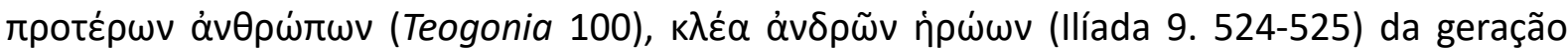
que marchou contra a cidade de Tebas e fracassou com a dos epígonos que a arrasou por completo, deixando-a em ruínas (Ilíada 2. 504; KIRK, 1985, p. 194). Esta narrativa de saque e destruição de cidade fazia parte do terceiro poema do Ciclo Tebano: Epígonos (éríyovoı "os nascidos depois", "a segunda geração"). Como é também o caso da Tebaida, sabemos tão pouco sobre o poema dos Epígonos que é preciso apelar para resumos de escritores antigos para tentar entrever algum elemento do seu enredo e dos seus episódios constitutivos (para tal são especialmente importantes: Apolodoro, Biblioteca, 3.7.2-5; Pausânias 9.5.13; Diodoro da Sicília 4.66-67) $\left.{ }^{(42}\right)$.

Dez anos depois dos eventos da Primeira Guerra de Tebas, os epígonos marcham mais uma vez contra a cidade para vingar a morte dos seus pais. Se, por um lado, a expedição de Adrasto estava fadada ao fracasso desde o início, fracasso inclusive previsto por Anfiarau nos sinais divinos, a expedição dos epígonos tem a chancela divina do Oráculo de Delfos. O filho de Anfiarau, Alcméon é escolhido como líder do exército. Assim como seu pai, num primeiro momento o herói apresenta resistência, mas depois deixa-se persuadir por sua mãe, Erífile. Assim como na Tebaida, em que Erífile persuade o marido depois de receber como suborno

3.6.2; Tebaida 11 Torres-Guerra = 7 West; schol. ad Píndaro, Nemeia 9.30b; Odisseia 11.326-327; 15.246-248 schol. ad Homero, Odisseia 11.326; Diodoro da Sicília 4.66.3.

41 Infra, p. 130.

42 CINGANO (2015b, pp. 246-254); GANTZ (1993, pp. 510-518). 
o colar de Harmonia, nos Epígonos Erífile pesuade o filho, Alcméon, depois de receber o manto de Harmonia. Apolodoro relata que o exército primeiramente pilha a vizinhança da cidade de Tebas (Biblioteca 3.7.3). Em seguida, o exército tebano marcha contra os invasores e uma batalha campal se desenrola longe da cidade e de suas muralhas. Enquanto no poema da Tebaida a hoste argiva é destruída e só Adrasto retorna com vida, nos Epígonos, todos sobrevivem à batalha, com a exceção de Egialeu, fiho de Adrasto. Em seguida, o restante do exército tebano bate em retirada rumo a cidade. Por sugestão de Tirésias, o povo tebano negocia um armistício para enterrar os mortos como pretexto para escapar da cidade antes da chegada do exército e da sua posterior destruição (Apolodoro, Biblioteca 3.7.3; Pausânias 9.33.1; Diodoro da Sicília 4.66-5.67). O poema provavelmente terminava com o retorno de Alcméon para cumprir a ordem de Anfiarau: matar sua própria mãe. Às vezes essa conclusão formava uma narrativa totalmente separada, um quarto poema, a Alcmeonideia. Está claro que Epígonos dependia e presupunha a Tebaida, de modo que seu enredo, episódios e cenas eram construídas em paralelismo, duplicações e contrastes $\left({ }^{43}\right)$.

Eis a passagem de Ilíada 4. 370-418:

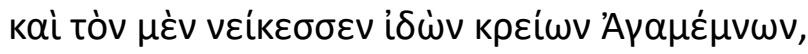

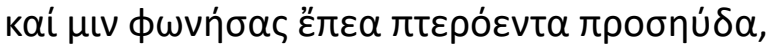

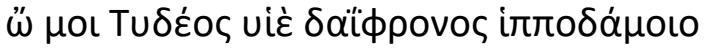

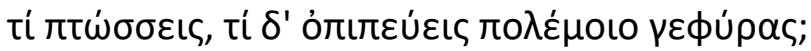

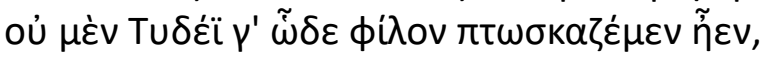

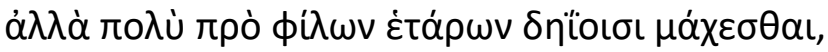

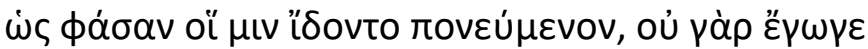

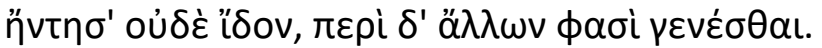

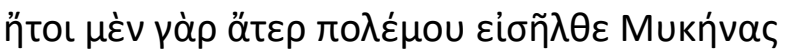

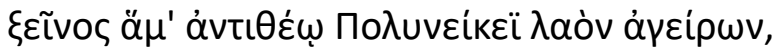

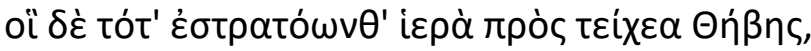

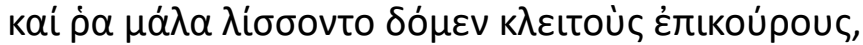

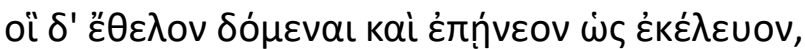

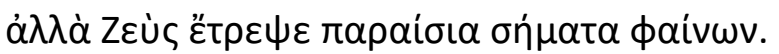
oï $\delta$ '

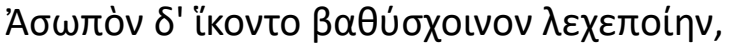

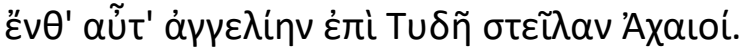

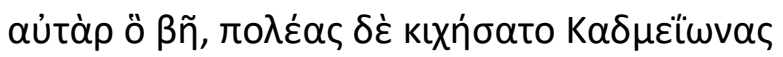

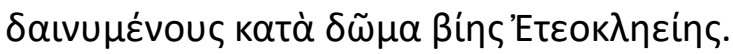

43 CINGANO (2015b, pp. 246-254). Ver EBBOTT (2015, p. 332) para a ideia de que a narrativa da Tebaida e dos Epígonos representa os dois possíveis desfechos de um mesmo enredo-padrão. 


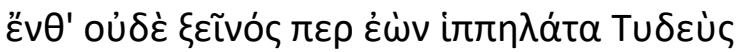

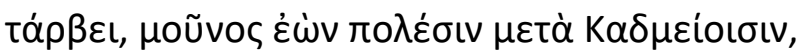

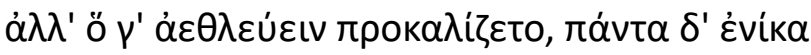

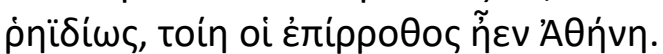

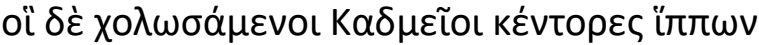

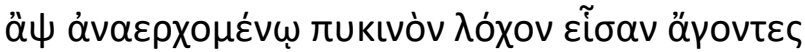

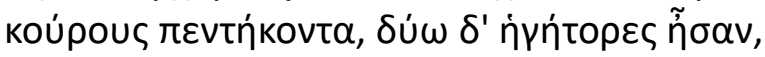

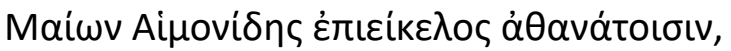

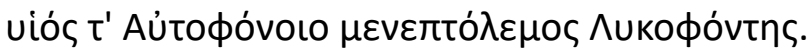

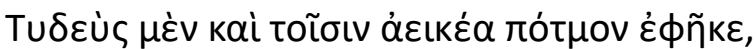

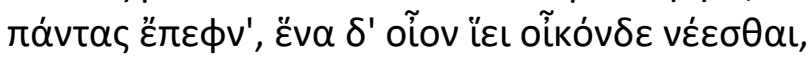

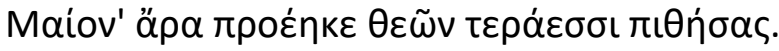

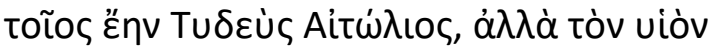

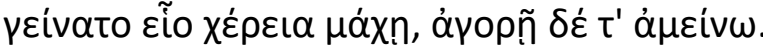

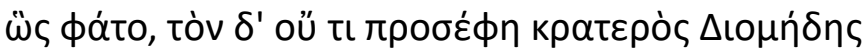

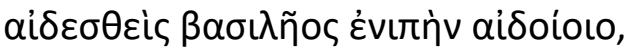

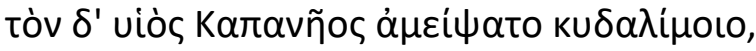

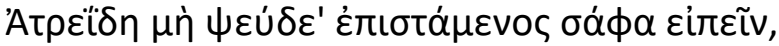

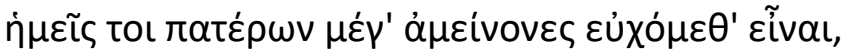

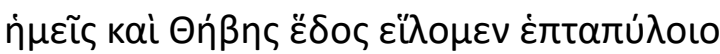

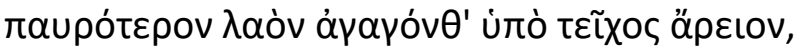

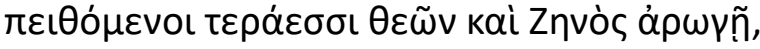

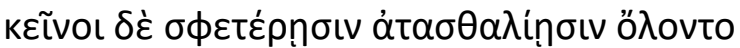

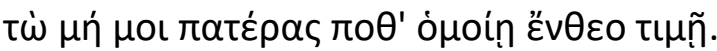

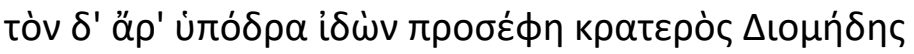

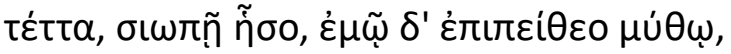
oủ үà

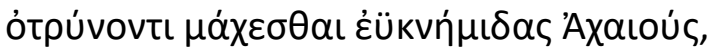

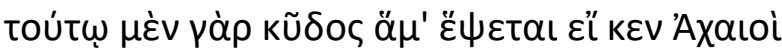

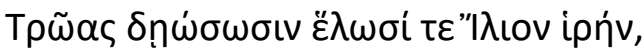

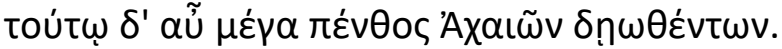

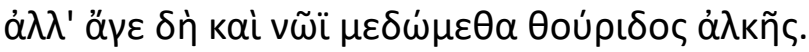

Quando o viu, repreendeu-o Agamêmnon soberano dos homens, e falando-Ihe proferiu palavras aladas:

'Ah, filho do fogoso Tideu, domador de cavalos!

Por que hesitas? Por que olhas para as alas da guerra?

Deste modo não tinha Tideu o costume de ficar para trás, Mas combatia os inimigos muito à frente dos companheiros, segundo diz quem o viu esforçando-se na guerra; pela minha parte, nunca o conheci nem vi, mas dizem que ele era superior aos outros. Uma vez veio até Micenas, mas não com intento belicoso, como hóspede do divino Polinices, para juntar um exército. Nesse tempo levavam a guerra contra as sagradas muralhas de Tebas 
e muito suplicavam eles para que Ihes concedessem famosos aliados.

E os Micênios queriam atendê-los e assentiam quando pediam;

mas Zeus desviou as decisões mostrando portentos desfavoráveis.

Depois que partiram e estavam já a caminho,

chegaram ao Asopo de fundos juncais reclinados na relva;

foi aí que os Aqueus mandaram Tideu numa missão:

e ele foi encontrando muitos dos filhos de Cadmo

banqueteando-se em casa da Força de Etéocles.

Então, embora estrangeiro, não teve receio o cavaleiro Tideu, apesar de só no meio de tantos dos filhos de Cadmo.

Desafiou-os para as contendas atléticas, e tudo ele ganhou

facilmente. Pois quem o ajudava era a deusa Atena.

Mas encolerizaram-se os filhos de Cadmo, chicoteadores de cavalos,

e quando ele regressava armaram uma forte cilada

de cinquenta mancebos. Dois destes comandavam:

Méon, filho de Hêmon, igual dos deuses imortais;

e o filho de Autófono, o seguro guerreiro Polifontes.

Mas Tideu fez desabar sobre eles um destino vergonhosomatou-os a todos; só a um deixou que regressasse a casamandou embora Méon, obedecendo aos portentos dos deuses Tal era Tideu da Etólia; mas o filho que gerou é pior que ele na guerra, embora seja melhor na conversa'. Assim falou, mas nada respondeu o possante Diomedes, por respeito para com a reprimenda do deus venerando. Mas deu-lhe resposta o filho do glorioso Capaneu:

'Atrida, não profiras mentiras, quando sabes dizer a verdade, Nós declaramo-nos de longe melhores que os nossos pais. Conquistamos a sede da heptápila Tebas, quando ambos juntamos uma hoste menor sob uma muralha mais forte, tendo acreditado nos portentos divinos e na ajuda de Zeus. Por seu lado, pereceram eles devido à sua própria loucura. Por isso não coloques os nossos pais em honra igual à nossa'. Fitando-o com sobrolho carregado respondeu o forte Diomedes: 'Amigo, fica em silêncio e obedece às minhas palavras: não considero vergonhoso que Agamêmnon, pastor do povo, incite a combater os Aqueus de belas cnêmides. Dele será a glória na eventualidade de os Aqueus chacinarem os Troianos e tomarem a sacra Ílion; e sobre ele se abaterá o sofrimento, se forem os Aqueus chacinados. Que agora tu e eu nos concentremos na coragem feroz'.

Está claro que a história contada por Agamêmnon ocorreu no contexto da Primeira Guerra de Tebas, como ele mesmo a localiza temporalmente: "Nesse tempo levavam a guerra contra as

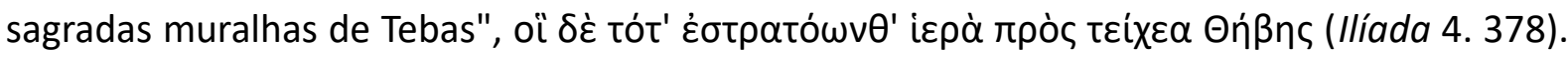


Tideu, o pai de Diomedes, acompanha Polinices numa missão diplomática em Micenas sem

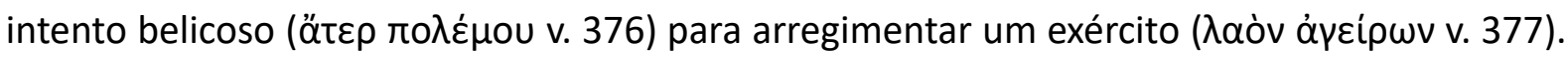
Embora a convocação de aliados para a guerra jamais seja narrada efetivamente como uma cena-padrão nos poemas homéricos, referências estão amplamente disponíveis, ainda que nas mais das vezes sejam muito breves. Essa unidade temática surge incrivelmente abreviada no relato de Nestor sobre o confronto entre pílios e árcades junto às correntes do Celadonte:

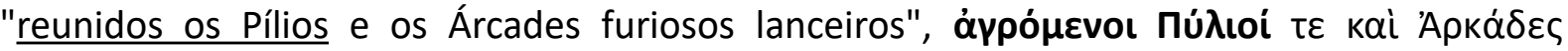

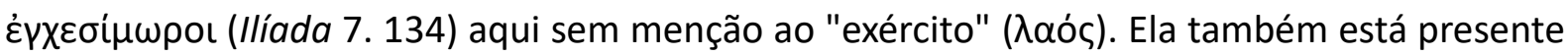
quando Aquiles formula a pergunta sobre a razão de o exército grego se encontrar em Troia:

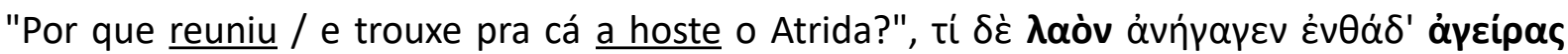
(Ilíada 9. 337-339). Encontramos também referência a uma missão diplomática itinerante formada por Nestor e Odisseu, na qual os dois excelentes oradores do exército grego fazem uma visita a Peleu, pai de Aquiles, para arregimentar tropas para a Guerra de Troia: "para

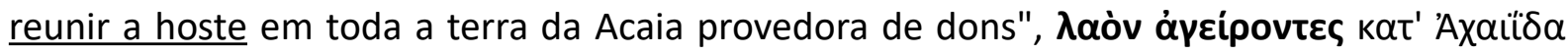

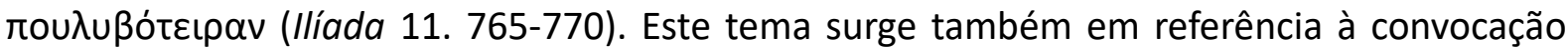
dos aliados troianos (Ilíada 17. 215-224) e à convocação trabalhosa de Odisseu (Odisseia 24. 114-119). E nem só homens mortais viajam em semelhante missão. Duas menções na Ilíada mostram que deuses também agiam como embaixadores ou os acompanhavam, como Hera em 4. 24-29 e 51-63 e Atena em 11. 714-717 $\left({ }^{44}\right)$.

Agamêmnon informa em seu discurso que Polinices e Tideu percorreram a vizinhança promovendo semelhante alistamento para o exército: "muito suplicavam para que lhes

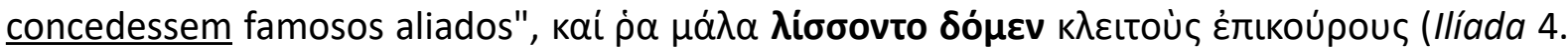
379). Presume-se que esta dupla de oradores, como Nestor e Odisseu, tem excelente resultado em sua empreitada, uma vez que os habitantes de Micenas aprovavam o pedido e

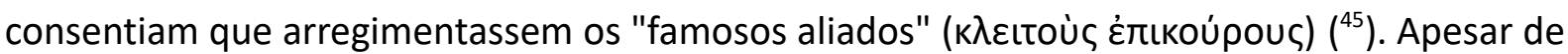
Polinices e Tideu terem obtido sucesso nesta missão diplomática, seus objetivos não serão alcançados por efeito do imponderável divino: "mas Zeus desviou as decisões, mostrando

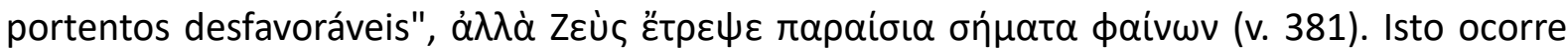
porque desde o início a expedição dos sete contra Tebas também ia contra a vontade divina

44 Ver EBBOTT, (2014) sobre essa unidade temática.

45 Ver EBBOTT (2014) para uma interpretação desta expressão formular. 
(Hesíodo frag. 135 Most = 193 Melkerbach-West = Píndaro, Nemeia 9.18-20).

Esta primeira embaixada, cujo relato é mais conciso do que o da missão subsequente, tem como finalidade destacar a habilidade oratória, a competência retórica, do personagem principal. Em outra embaixada da Ilíada essas qualidades também recebem destaque. Um

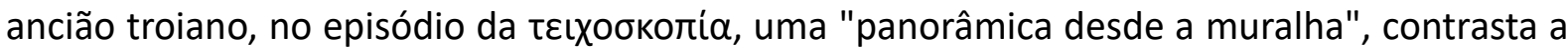
aparência de Odisseu, que lhe dava uma impressão negativa, com a sua incrível eloquência: "dirias que era um palerma, alguém sem inteligência/ mas quando do peito emitia sua voz

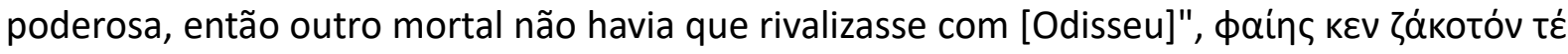

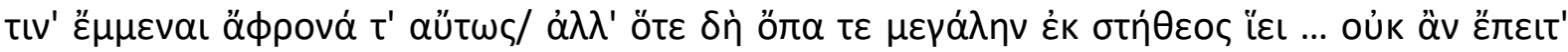

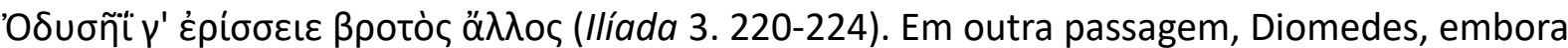
esteja falando da segunda missão, descreve da seguinte forma a mensagem que Tideu levou

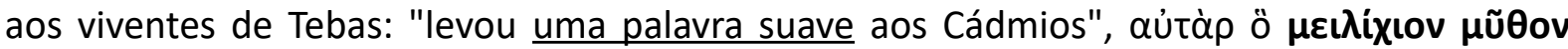

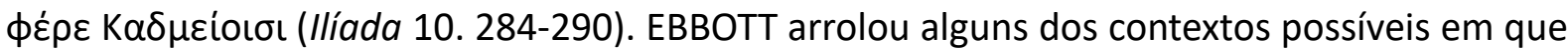
esta expressão formular ocorre nos poemas homéricos (2010, pp. 249-252). Ela reconhece dois sentidos que seriam mais adequados ao relato de Agamêmnon: o emprego de "palavras suaves" para tentar aplacar ou evitar a raiva do interlocutor ("assuage or forestall someone's anger", Ilíada 21. 339; 6. 343; Odisseia 16. 279; 6. 143); e para convencer um amigo que se tornou inimigo ("persuade a friend turned enemy", Odisseia 11. 552; llíada 9. 113). Por óbvio, praticamente qualquer personagem pode utilizar esta estratégia retórica nos poemas, porém é notável que Tideu esteja entre eles, ao lado de Odisseu, Penélope, Helena e Nestor, aqueles que nos poemas fazem o melhor uso da palavra.

Há ainda um outro ponto de contato entre a cena da embaixada de llíada 3 e a figura de Tideu. Pouco antes aquele mesmo ancião troiano que comentara sobre os dons oratórios de Odisseu, havia notado que, comparado a Menelau, ele impunha menos respeito e parecia ter menor estatura. Tideu também compartilha tal característica com Odisseu: "Tideu [tinha]

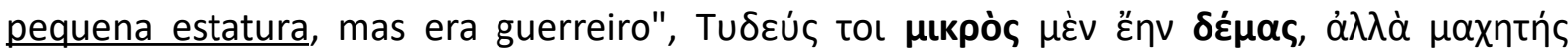
(Ilíada 5. 800). A oposição entre aparência externa e qualidades internas é um tema comum em poesia homérica. Além da ocorrência deste tema nestes episódios envolvendo Odissesu e Tideu, ele pode ser encontrado, por exemplo, na segunda canção de Demódoco, que narra o amor entre Ares e Afrodite (Odisseia 8. 266-369; DE JONG, 2001, pp. 207-208). 
Se na primeira missão diplomática o relato de Agamêmnon sublinha as capacidades retóricas de Tideu, a segunda missão enfatiza sua disposição e talento para a guerra. Esta segunda parte da narrativa é contada mais demoradamente. De forma que a estrutura geral do relato deve ser reconhecida como uma "duplicação antecipatória" $\left({ }^{46}\right)$. Uma ferramenta bastante conhecida na qual um padrão narrativo se repete duas vezes, na primeira de forma concentrada, na segunda vez de forma expandida. SAMMONS (2014) aplica os conceitos de "paz" e "guerra" para sistematizar esta narrativa. Teríamos na primeira parte uma embaixada de "paz", enquanto que, na segunda, teríamos uma embaixada de "guerra". A narrativa que trata da embaixada de "guerra" seria subdivida em uma fase de "paz" e uma de "guerra" $\left({ }^{47}\right)$. Entretanto, também podemos utilizar categorias homéricas para organizar a narrativa, como

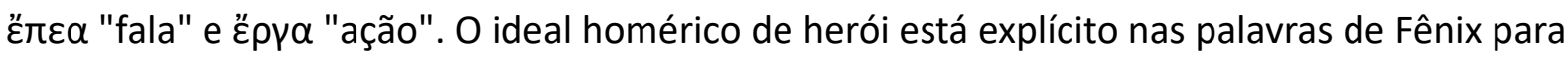
Aquiles em llíada 9. Um bom guerreiro deve ser um "orador de discursos e fazedor de

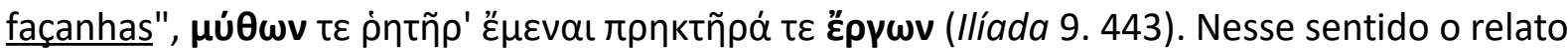
de Agamêmnon compreenderia uma primeira parte relacionada ao uso persuasivo da palavra

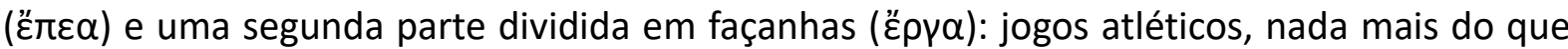
uma espécie de guerra com regras (Ilíada 4. 387-390) e façanhas militares no sentido estrito (vv. 391-398).

Em Tebas Tideu encontra os cádmios realizando um banquete na casa de Etéocles. $\mathrm{O}$ herói encontra-se sozinho entre os tebanos, diferente do episódio na narrativa embutida do ancião troiano (Ilíada 3. 203-224) em que Menelau e Odisseu apareciam juntos, e da missão diplomática a Micenas, em que Tideu estava acompanhado de Polinices. Por outra narrativa embutida, de Diomedes em Ilíada 10. 284-290, ficamos sabendo que Tideu, amistosamente,

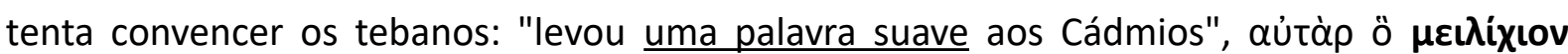

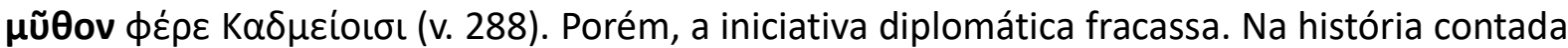
por Agamêmnon, a narrativa toma imediatamente a forma de desafio: "desafiou-os para

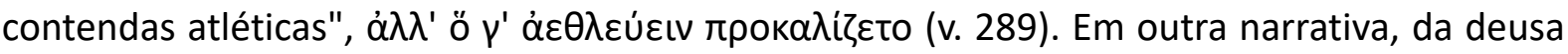
Atena em Ilíada 5. 800-808, obtemos uma informação que Agamêmnon provavelmente desconhecia: Tideu queria enfrentar os tebanos e precisou ter seu entusiamo para a guerra

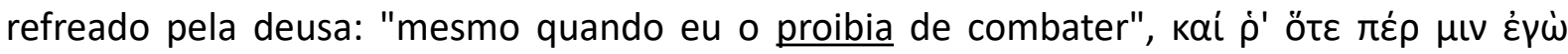

46 Ver SAMMONS (2014, p. 302).

47 Ver SAMMONS (2014, p. 308). 


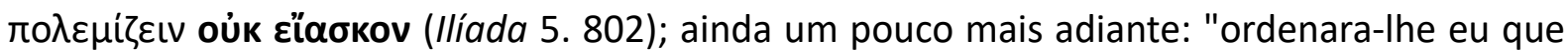

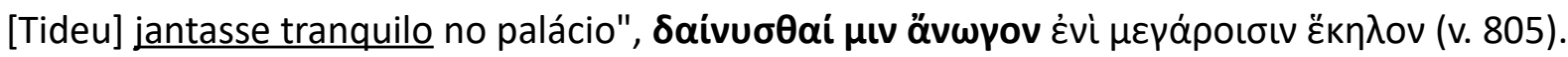
Podemos imaginar uma versão mais extensa deste episódio que inclua uma a cena de uma Atena descendo do céu para segurar Tideu pelos cabelos. O prazer do guerreiro no combate

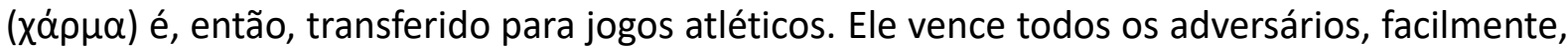
com a ajuda da deusa.

Na esteira de SAMMONS (2014) também consideramos a comparação com o episódio dos jogos atléticos na ilha dos Feácios descabida. Embora naquele episódio os jogos atléticos substituam simbolicamente o confronto, a caracterização dos personagens é completamente diferente. Sabidamente, neste episódio, Odisseu encontra-se em processo de recuperação do sua identidade e status heroicos. No caso de Tideu parece que o herói descobre um caminho intermediário para satisfazer o seu ímpeto guerreiro sem abandonar completamente a sua segurança e as preocupações diplomáticas da deusa Atena.

Os tebanos ressentidos preparam uma emboscada. Estavam em cinquenta escudos e

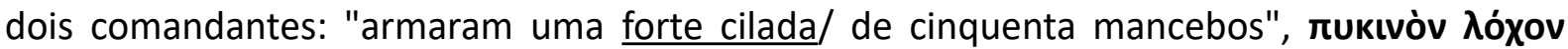

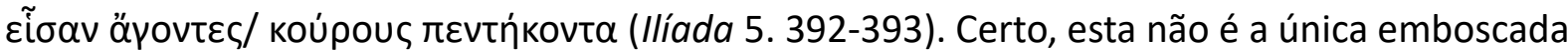
nos poemas homéricos, a bem da verdade, trata-se de um tema, uma unidade tradicional, plenamente desenvolvida na tradição épica arcaica. A poética da emboscada foi estudada principalmente por A. T. EDWARDS (1985) em seu trabalho sobre Aquiles na Odisseia e por DUÉ \& EBBOTT (2010) em uma edição multitextual de Ilíada $10\left({ }^{48}\right)$. Segundo esses autores, a emboscada estabeleceria uma forma de combate alternativa à batalha convencional, onde prevalece o emprego da astúcia ( $\mu$ ñtıఢ) por oposição à força bruta ( $\beta \dot{i} \alpha)$. O tema apresenta os seguintes padrões narrativos quando é integralmente desenvolvido: (1) escolher os melhores homens como comandantes ou integrantes da emboscada; (2) armar-se ou preparar-se para o enfrentamento; (3) escolher um local para a cilada; (4) esconder-se e passar por momentos de tensão e desconforto durante a espera; (5) o ataque supresa; (6) o retorno para casa $\left({ }^{49}\right)$. O tema estaria presente na Doloneia em Ilíada 10 , na narrativa sobre Belerofonte (Ilíada 6. 187-190); no Escudo de Aquiles (Ilíada 18. 513-522); em uma das "mentiras cretenses" do mendigo/Odisseu (Odisseia 13. 256-286); no episódio do cavalo de

48 Ver VIEIRA (2016, pp. 78-101); DUÉ \& EBBOTT (2010, pp. 31-88), para uma panorâmica do tema.

49 DUÉ \& EBBOTT (2010, p. 70). 
madeira (Odisseia 8. 492-498); na emboscada de Menelau (Odisseia 4. 431-459) dentre muitos outros.

Os líderes da tocaia e seus pais ostentam noms parlants. Méon, possivelmente, deriva de $\mu \alpha i$ í $\alpha$ " "perseguir", enquanto Hêmon deve provavelmente significar "aquele que caça",

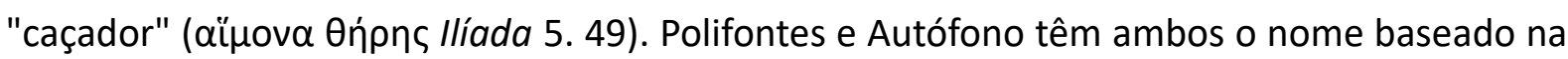
palavra фóvoৎ "assassinato". Tideu mata quarenta e nove dos seus agressores. Apenas Méon

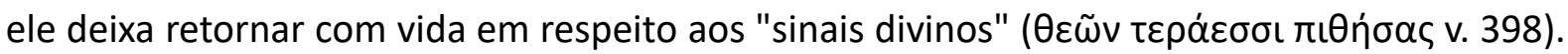
O episódio da missão diplomática a Micenas, assim como o episódio da embaixada a Tebas, terminam com uma referência a uma espécie de interferência divina. Existe um paralelo para esse fenômeno no relato de Glauco sobre os "trabalhos" de Belerofonte (Ilíada 6. 179-183). O episódio também aqui se encerra com a expressão $\theta \varepsilon \omega \tilde{\nu} \tau \varepsilon \rho \alpha ́ \varepsilon \sigma \sigma \iota ~ \pi \iota \theta \dot{\sigma} \sigma \alpha \varsigma$, "obedecendo aos portentos dos deuses" (v. 183). KIRK (1990, p. 184) observa que esta expressão é usada como uma ferramenta para reduzir e concluir narrativas mais longas. No entanto, ela pode indicar no relato de Agamêmnon em Ilíada 4. 310-400, como também em Ilíada 6. 179-83, o favoritismo do herói por uma divindade. Entretanto, tanto Belerofonte, quanto Tideu, depois

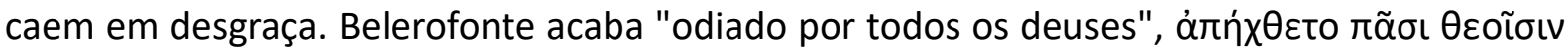
(Ilíada 6. 200). Ele termina sua vida como andarilho, vagueando por uma espécie de deserto distante e desabitado ou brejo das almas; o contrário dos Campos Elíseos mencionados em Odisseia 4. 562-569 $\left({ }^{50}\right)$. Em um fragmento que costuma ser atribuído à Tebaida, mas que às vezes é considerado duvidoso (WEST, 2003, p. 50-53), Tideu recebe em batalha um ferimento de Melanipo. Melanipo eventualmente é morto por Anfiarau, que leva a cabeça do inimigo a Tideu como prêmio. O herói abre a caixa craniana de Melanipo e lhe devora sofregamente o cérebro. Por sua vez, a deusa Atena, "que trazia para Tideu a imortalidade, ao ver o miasma,

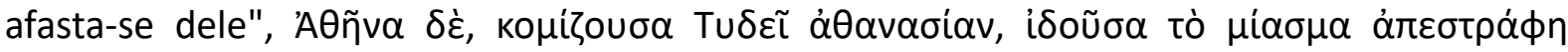
aútóv (Tebaida 7 Torres-Guerra $=11$ West $=6$ a Davies) $\left({ }^{51}\right)$. Esse comportamento hibrístico marca a mudança de postura da deusa em relação a Tideu.

Diomedes se mantém em silêncio, mas Estênelo, filho de Capaneu, compra a briga e responde à censura de Agamêmnon: "não profiras mentiras quando sabes dizer a verdade",

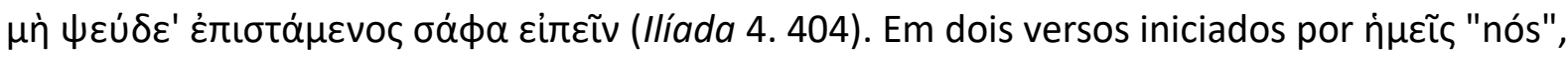

50 GRAZIOSI \& HAUBOLD (2010, p. 136).

51 Minha tradução. 
o filho de Capaneu afirma que a sua geração era melhor do que a anterior e explica porque

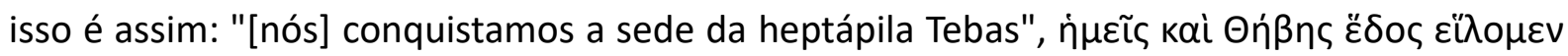

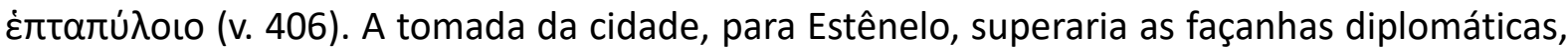
atléticas, bélicas e o favoritismo divino descritos por Agamêmnon e encontrados nos outros relatos sobre este episódio (Ilíada 5. 800-808 e Ilíada 10. 284-290), porque ali onde Polinices e Tideu fracassaram, Diomedes e Estênelo obtiveram êxito. Em segundo lugar, o contingente da sua expedição era menor: "juntamos uma hoste menor sob uma muralha mais forte",

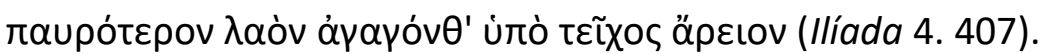

Já encontramos verso semelhante em outra passagem, na discussão entre Tlepólemo e Sarpédon em llíada 5, no mesmo contexto da comparação entre gerações de pais e filhos. Naquela cena Tlepólemo, filho de Héracles, acusava Sarpédon, filho de Zeus, de não honrar o seu parentesco com Héracles e Zeus. Para ilustrar esta afirmação, ele relata brevemente uma das façanhas de Héracles: "com seis naus e menor número de homens,/ [Héracles]

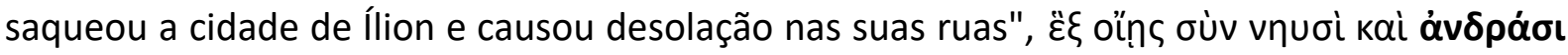

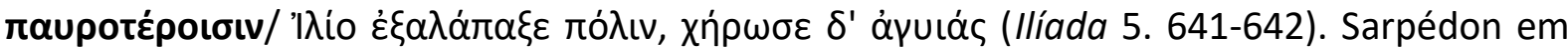
sua resposta procura reduzir a importância de Héracles, responsabilizando Laomedonte: "arrasou a sacra Ílion/ devido aos desvarios daquele homem, o altivo Laomedonte", кعĩvoৎ

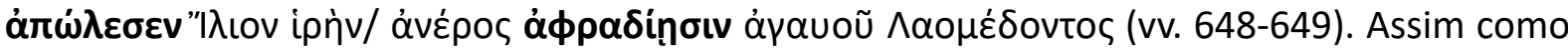
Sarpédon, Estênelo também atribui o fracasso da expedição de Adrasto à sua loucura: кعĩvoı

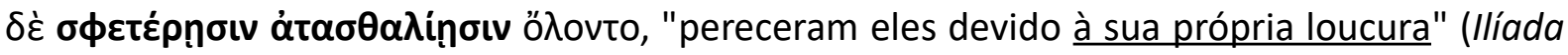

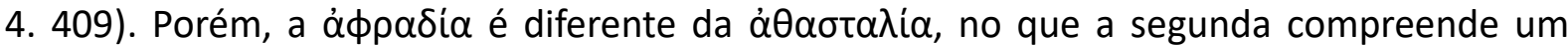
elemento adicional. Na Odisseia este comportamento vai caracterizar os companheiros de Odisseu, Egisto e os pretendentes de Penélope. DE JONG (2001, p. 12) define o termo como uma "conduta ultrajante ou irresponsável, que quebra normas sociais ou religiosas, e que as pessoas adotam apesar de alertas especificos" (it indicates outrageous or reckless behaviour wich breaks social or religous rules, wich people pursue despite specific warnings) $\left({ }^{52}\right)$.

O caso de Egisto é paradigmático, como explica Zeus em Odisseia 1. 32-43:

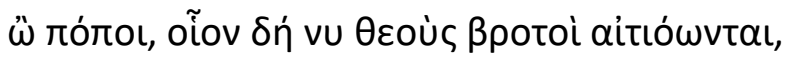

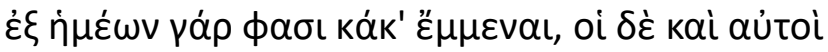

52 DE JONG (2001, p. 12). Ver também FINKELBERG (1995). 


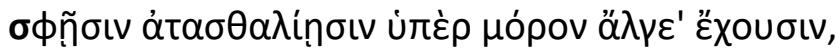

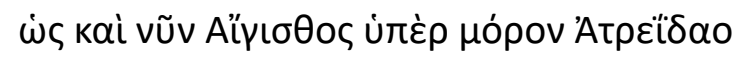

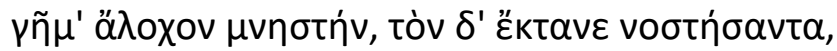

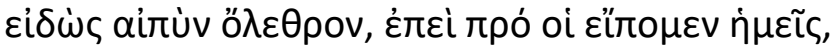

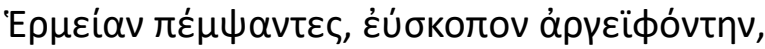

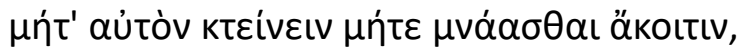

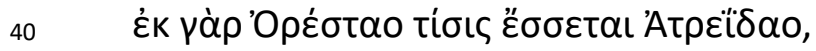

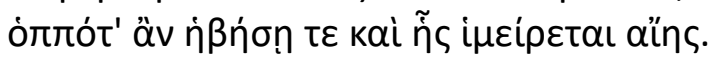

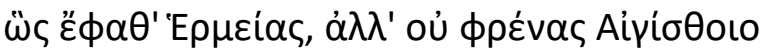

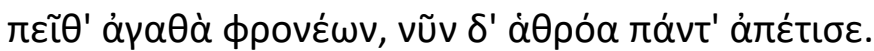

Vede bem como os mortais acusam os deuses! De nós (dizem) provém as desgraças, quando são eles, pela sua loucura, que sofrem mais do que deviam! Como agora Egisto, além do que Ihe era permitido, do Atrida desposou a mulher, matando Agamêmnon à sua chegada, sabendo bem da íngreme desgraçapois Ihe havíamos prevenido ao mandarmos Hermes, o vigilante matador de Argos: que não matasse Agamêmnon nem lhe tirasse a esposa, pois pela mão de Orestes chegaria a vingança do Atrida, quando atingisse a idade adulta e saudades da terra sentisse. Assim Ihe falou Hermes; mas seus bom conselhos o espirito de Egisto não convenceram. Agora pagou tudo de uma vez.

A fala de Zeus em Odisseia 1 exemplifica com clareza a conduta daqueles que devido

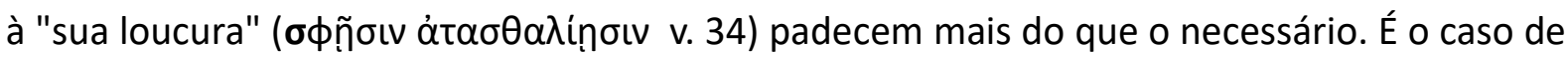
Egisto que esposa Clitemnestra, assassina Agamêmnon, muito embora estivesse avisado, por

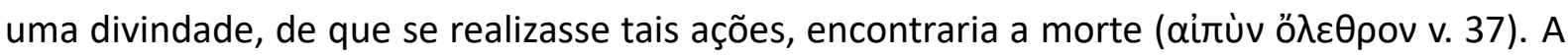

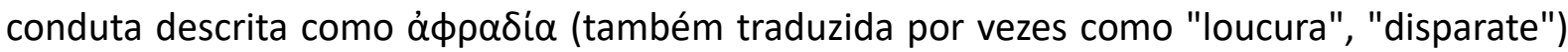

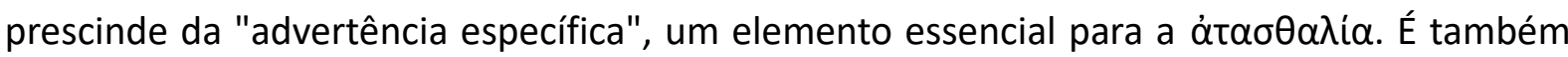
notável que, nas tipificações encontradas na Odisseia, o personagem responsável por alertar

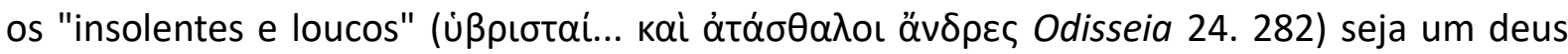
ou alguém que teve acesso a informação privilegiada de um deus: os pretendentes cortejam Penélope apesar das advertências de uma variedade de personagens, incluindo dois videntes e portentos divinos (Haliterses 2. 157-176; Teoclímeno 20. 350-394; águias 2. 146-156; falcão 15. 525-534); os companheiros de Odisseu devoram as cabeças de gado do Sol apesar dos 
alertas de Odisseu, que estava ciente dos riscos graças à Circe (Odisseia 12. 137-141); Egisto comete os seus crime apesar da advertência de Hermes (Odisseia 1. 32-43).

Deste modo, a crítica de Estênelo de que a geração anterior teria fracassado pela sua

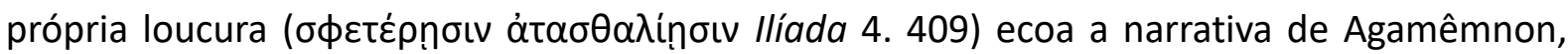
em que ignoram-se os sinais divinos enviados aos micênios: "mas Zeus desviou as decisões

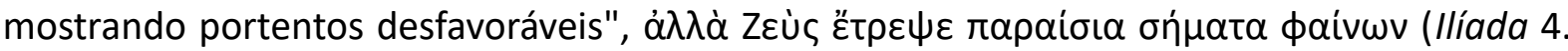
381). A percepção de Estênelo também vai ao encontro do enredo da Tebaida. Se pudermos confiar no resumo de Apolodoro (Biblioteca 3.5.7-3.7.1), o vidente e guerreiro Anfiarau deve ter se deparado com portentos divinos antes de integrar a expedição, o que explicaria a sua resistência em marchar para a guerra ao lado dos argivos. O mito de fundação dos jogos de Nemeia, que tem como pano de fundo a história de Hipsipile e a morte do bebê (Apolodoro, Biblioteca 3.6.4), também consiste em uma das advertências ignoradas pelos guerreiros da primeira expedição contra Tebas. A Tebaida inclusive apresentaria uma cena em que o pai de Estênelo, Capaneu, é fulminado pelo raio de Zeus enquanto escala as muralhas da cidade, um sinal óbvio de que a cidade não seria nem tomada, nem arrasada (Apolodoro, Biblioteca 3.6.7). É por essa razão que Estênelo faz referência à chancela divina e à ajuda de Zeus:

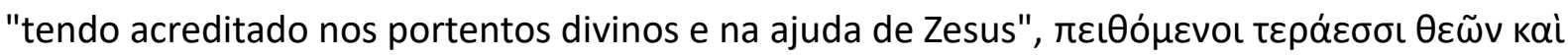

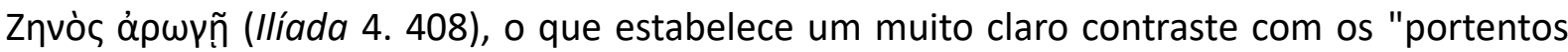

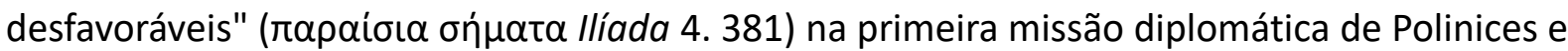
Tideu.

A resposta de Estênelo se encerra com o verso: "Por isso não coloques os nossos pais

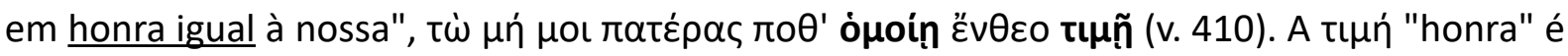
um tipo de distinção ou consideração social geralmente dispensada nos poemas homéricos à aristocracia, os soberanos que detém poder político na comunidade, mas também concedida àqueles indivíduos que exibem excelência guerreira. Ela se traduz em algumas prerrogativas, geralmente propriedades, um lugar de honra no banquete público ou real, mas também em um código de conduta, civilidade e deferência $\left({ }^{53}\right)$. A repreensão de Agamêmnon é percebida por Estênelo como um ato lesivo da honra porque é um desrespeito ao seu status dentro do exército, mas principalmente porque é um ataque à sua excelência guerreira e de Diomedes.

53 Ver especialmente VAN WEES (1992, p. 69); e também BENVENISTE (1969, pp. 43-55); ADKINS (1972, p. 3); CAIRNS (2011, p. 879); ASSUNÇÃO (2008). 
Portanto, encontramos nos discursos de Agamêmnon e Estênelo duas concepções diferentes da carreira heroica do guerreiro. Estênelo estima o sucesso das façanhas de um herói de acordo com três critérios: a excelência guerreira, a legitimidade de suas ações perante os deuses e o seu propósito primário, que nesta discussão era o saque e destruição da cidade de Tebas $\left({ }^{54}\right)$. Da perspectiva de Estênelo, Tideu seria inferior à geração posterior pelo menos em dois desses três aspectos. Agamêmnon, por outro lado, considera suficiente apreciar a carreira de um herói isoladamente e com base em seu ápice $\left({ }^{55}\right)$.

A resposta de Diomedes é surpreendente. Antes ele não havia se manifestado sobre o discurso de Agamêmnon; como se aceitasse a censura, decidiu-se por manter silêncio. Agora, em vez de defender as façanhas dos epígonos, Diomedes parece, inesperadamente, censurar o seu amigo e escudeiro, Estênelo. Eis a sua descrição: "fitando-o com sobrolho carregado

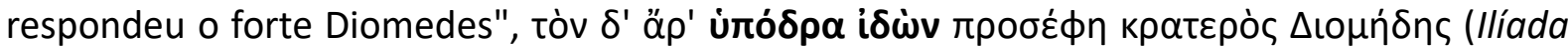

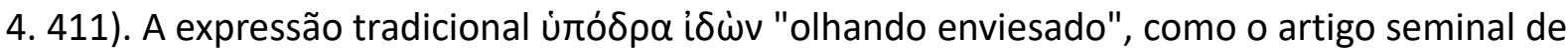
HOLOKA $(1983$, p. 4) mostra, "manifesta a raiva de um orador que leva a mal as palavras, que ele julga desrespeitosas ou indelicadas, pronunciadas por seu interlocutor" ("convey anger on the part of a speaker who takes umbrage at what he judges to be rude or inconsiderate words spoken by the addressee"). A reação dos oradores que recebem semelhante descrição é muitas vezes extrema: Aquiles ofende e cogita matar Agamêmnon (Ilíada 1. 148); Odisseu repreende e agride Tersites (Ilíada 2. 245); Zeus repreende e ameaça torturar e agredir Hera (Ilíada 15. 13); Aquiles e Heitor trocam ofensas antes do duelo (llíada 20. 428); em outra cena, Diomedes vai além das ameaças e agressões e decapita Dólon (Ilíada 10. 446); Odisseu "fita com sobrolho carregado" e decapita Leodes (Odisseia 22. 320). Resta evidente que esta maneira de olhar um interlocutor é potencialmente perigosa e pode sinalizar uma escalada da violência. No entanto, os desfechos não são uniformes e, no mais das vezes, o conflito permanece apenas no plano verbal. Para HOLOKA $(1983$, p. 5), um padrão mais importante é a relação hierárquica entre o orador/superior e o interlocutor/subordinado: Heitor censura Polidamante em decorrência da interpretação desfavorável que ele fizera de um portento divino (Ilíada 12. 230); Zeus censura Ares (Ilíada 5. 888); Heitor censura Glauco (Ilíada 17. 169). A importância da hierarquia, da mesma forma, pode ser reconhecida nas cenas entre 
Odisseu e Tersites, e Zeus e Hera, supracitadas.

Assim, Diomedes repreende Estênelo incomodado com a conduta equivocada do seu escudeiro. Para Diomedes, Estênelo inocentemente não percebeu que Agamêmnon apenas está cumprindo a sua função de comandante do exército: "não considero vergonhoso que Agamêmnon, pastor do povo/ incite a combater os Aqueus de belas cnêmides", oủ үà $\rho$ غ̇үu்

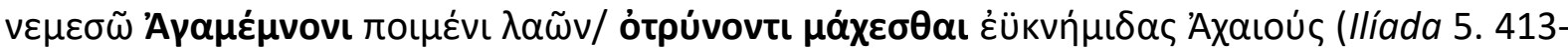
414). Diomedes usa o argumento de Estênelo, quando lembra que a expedição e a reputação de Agamêmnon ainda estão em aberto, já que Troia ainda não foi destruída: "Dele será a glória na eventualidade de os Aqueus/ chacinarem os Troianos e tomarem a sacra Ílion",

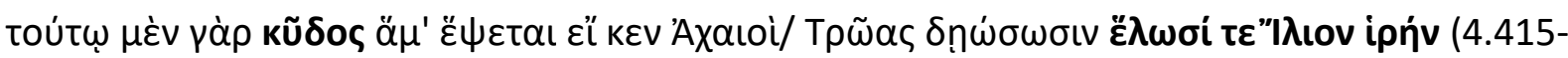
416). Todavia, alguns dos estudiosos defendem que Diomedes, no final das contas, dá razão a Agamêmnon. Diomedes parece defender que a história da Guerra de Troia e da liderança de Agamêmnon ainda não se concluíram, mas antes se encontram ainda em andamento. Para SLATKIN (2011 p. 113), "a narrativa inacabada na qual [Diomedes] e Estênelo habitam no momento presente - a qual não é dominada pelos seus pais - vai registrar outras timai sem precedentes e, com a participação de ambos, estabelecerá a sua própria referência de kûdos e penthos" ("the unfinished narrative he and Sthenelos now inhabit - one not dominated by theirs fathers - will record other, unprecedented timai and, with their participation, establish its own standard of kûdos and penthos").

SLATKIN (2011, pp. 115-116) foi a primeira a notar que por detrás destas narrativas há uma rivalidade poética entre as tradições representadas pelo Ciclo Tebano e pela Ilíada. Ela nota que quando Aquiles deixa a cena na llíada, Diomedes passa a receber maior destaque na narrativa, pelo que também ganham relevo as façanhas da geração que lutou na Primeira e na Segunda Guerra de Tebas. A rivalidade, todavia, não deve ser vista meramente como um embate entre duas tradições diversas, mas como um embate entre duas perspectivas sobre a excelência guerreira na carreira heroica: a perspectiva de Estênelo (e Tlepólemo), que não é outra coisa senão a perspectiva do saque e destruição de cidades; e a perspectiva de Agamêmnon, que é a perspectiva da llíada e do narrador homérico.

Primeiramente, é preciso reafirmar a interpretação tradicional que compreende essas 
passagens como uma tensão entre gerações, entre o passado e o presente $\left({ }^{56}\right)$. Presume-se que este é o caso na linguagem tradicional da poesia homérica, que estabelece regularmente este vínculo por meio do emprego constante do patronímico, especialmente na llíada $\left({ }^{57}\right)$. O uso do patronímico pode ser entendido como um fato sócio-cultural, bem como em termos

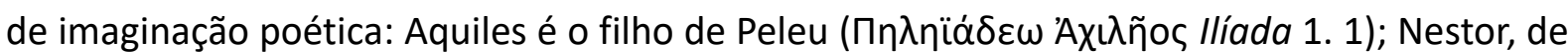

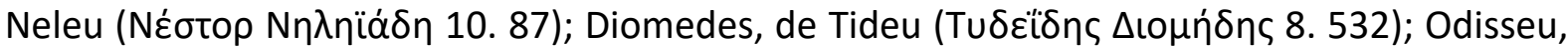

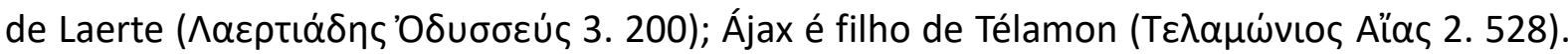
Frequentemente, a fim de estabelecer a identidade do herói, o patronímico é mais do que

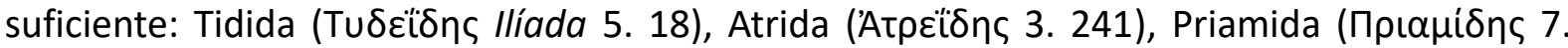

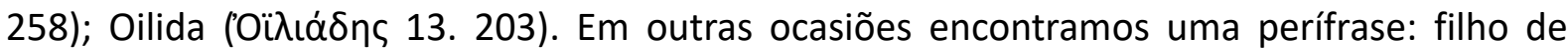

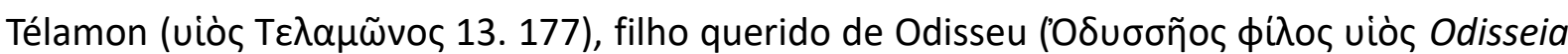
2. 2). Esta é uma forma de expressão tão generalizada na Ilíada que só Tersites não recebe um patronímico ou tem o local de origem mencionados (KIRK, 1985, p. 138). Esta associação persistente com o passado recente e remoto trazer a oportunidade para a utilização poética mediante convergências, como entre Odisseu e Telêmaco (Odisseia 2. 232-233) por exemplo, ou polarizações, entre Sarpédon e Héracles (Ilíada 5. 633-651) $\left({ }^{58}\right)$.

Depois, o contraste entre as gerações passadas de homens e a presente geração é conspícuo no poema: além do contraste entre Diomedes e Tideu no discurso de Agamêmnon (Ilíada 4. 370-400) e entre Sarpédon e Héracles no de Tlepólemo (5. 633-651), encontramolo em um discurso de Nestor. $\mathrm{O}$ ancião censura a conduta de Agamêmnon e de Aquiles, recuperando, em uma narrativa embutida breve, um episódio do passado, em que ao lado de Pirítoo, Driante, Ceneu, Exádio, Polifemo, Teseu e Egeu, participa de uma excursão contra os

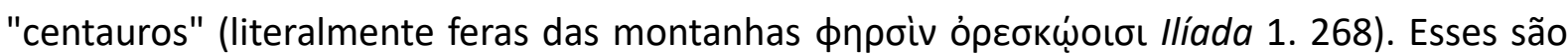
heróis de gerações passadas e são descritos por Nestor desta forma: "Pois já eu [estive] com

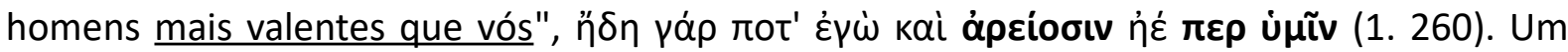
pouco mais adiante: "nunca homens assim eu [vi nem] alguma vez verei", oủ yá $\pi \omega$ toíous

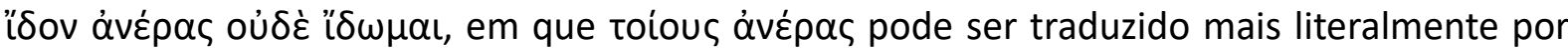
"homens de semelhante qualidade" (1. 262). A superioridade da geração passada sobre a

56 KIRK (1985, p. 374); SLATKIN (2011, pp. 100-101); EBBOTT (2014), contra SAMMONS, (2014, p. 306).

57 DE JONG (2001, pp. 524-525 e 535).

58 GRAZIOSI \& HAUBOLD $(2005$, p. 57-58). 
geração presente é sublinhada ainda mais duas vezes: "os mais fortes foram eles, e com os

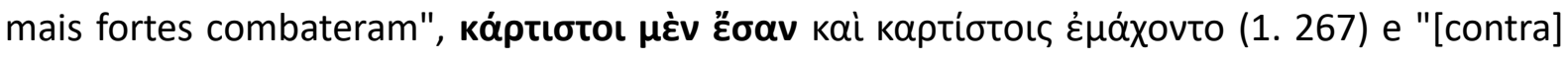

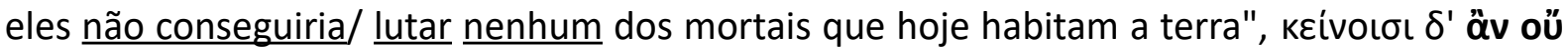

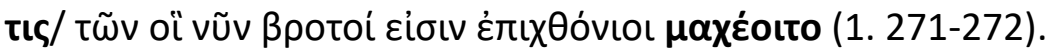

Em outra narrativa embutida de Nestor, é possível entrever elementos deste mesmo contraste entre gerações. Em um discurso de reprovação direcionado para todo o exército, o ancião relembra uma das suas façanhas do passado que serve de exemplo paradigmático de conduta para os guerreiros que o escutam, um paradeigma (llíada 7. 125). Nestor começa o seu discurso imaginando como Peleu, o pai de Aquiles, reagiria se porventura presenciasse o comportamento do exército naquela momento: "ah, como é grande a desgraça que à Acaia

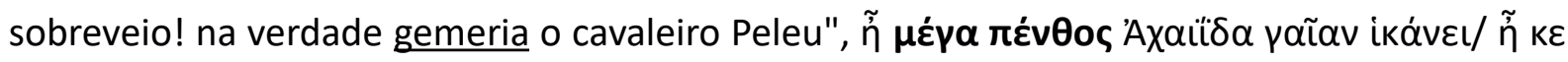

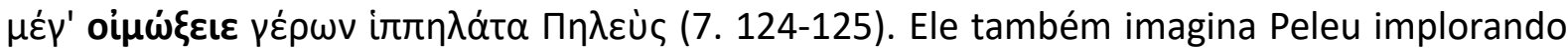
aos deuses para morrer: "muitas vezes elevaria aos imortais as suas mãos para que/ dos seus

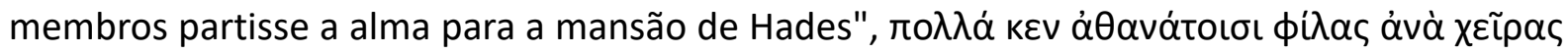

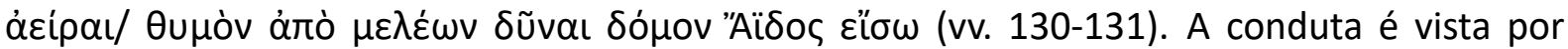
Nestor como uma "grande desgraça" e, para ele, a reação de Peleu seria gemer oï $\mu$ oı "ai, ai" de tristeza. Não à toa Nestor imagina Peleu, um herói do passado, cuja excelência guerreira foi provada em combate: com isso o ancião cria uma justaposição de gerações, com prejuízo para os novos guerreiros que aparentam não estar à altura de seus antepassados. Em termos de rivalidade poética, na esteira de SLATKIN (2011), seria seguro dizer que todo momento em

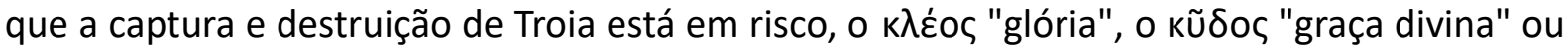

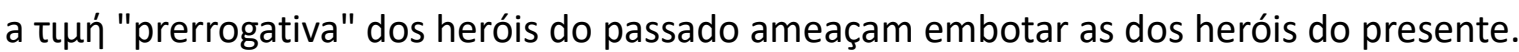

Para concluirmos o argumento, acreditamos que seja necessário examinar ainda dois outros pontos, ainda que brevemente: a concepção grega de tempo e o progresso da história do cosmos no continuum mitológico compreendido pelo epos hexamétrico e a relação entre a tradição de poesia hexamétrica homérica e pré-homérica ou não-homérica. Na esteira do trabalho comparativo de HAUBOLD (2002) e do trabalho de FORD (1994), podemos organizar cronologicamente as narrativas épicas em períodos particulares, desta vez acrescentando os poemas de outras tradições, além da homérica e hesiódica, que não constam nesses autores: o primeiro período seria marcado pela (1) cosmogonia e nascimento dos deuses. A Teogonia 
de Hesíodo representa esse período e nele encontramos o cosmos em instabilidade política e, por falta de palavra melhor, ontológica. Há uma disputa intensa pelo poder no que deuses surgem, geram outros deuses que, por sua vez, reclamam para si uma parte do cosmos. Zeus é uma força estabilizadora e organizadora nesse período. Depois, os Hinos Homéricos servem de transição para um cosmos bem-estabelecido, ao narrar os últimos ajustes políticos entre os deuses. O segundo período é dos heróis, (2) o passado remoto da humanidade. O poema Catálogo das Mulheres de Hesíodo também serve de transição do primeiro período para o segundo no que narra os encontros mais íntimos entre deuses e seres humanos. Devem ser incluídos aqui os poemas sobre Héracles e Teseu, os poemas do Ciclo Tebano, os poemas do Ciclo Troiano e a llíada e a Odisseia de Homero, nesta ordem. Finalmente, o terceiro período diz respeito ao (3) passado recente da humanidade. Aqui encaixamos os Trabalhos \& Dias de Hesíodo, que aborda uma variedade de questões, mas sempre voltado para o homem do seu tempo $\left({ }^{59}\right)$.

A história do cosmos, como narrada pelo epos hexamétrico, é uma lenta progressão de um passado extraordinário, em que deuses cultivavam a intimidade com seres humanos, para o contato intermediado pelo sacrifício, a linguagem cifrada dos sinais e oráculos; de um tempo em que heróis derrotavam monstros e criaturas amorfas, arrasavam cidades com um punhado de homens, para o presente mais trivial, em que já não existem mais criaturas para serem derrotadas, em que os deuses não são mais vistos nos bosques, nem nos montes. A Ilíada ainda conserva bastante dessa relação íntima entre deuses e homens. Eles conversam, guerreiam; Aquiles tem acesso quase que direto a Zeus por intermédio de sua mãe, Tétis. Na Odisseia, no entanto, encontramos os deuses mais distantes dos homens, como se tivessem desistido das interações. Os poemas homéricos estabelecem rivalidade com as façanhas das gerações anteriores e procuram mostrar que a nova geração, ainda que mais fraca, menos extraordinária, pode fazer com que o seu $\mathrm{k} \lambda \dot{\text { ó }}$ seja ouvido mais além e por mais tempo.

Se a llíada e a Odisseia estabelecem rivalidade poética com a matéria das canções das gerações anteriores, também deve ser verdadade que esses poemas estabelecem rivalidade com as outras formas paralelas de se narrar poesia épica. A tradição poética arcaica decerto abrangia uma enorme quantidade de poemas de natureza oral que nunca receberam 
expressão ortográfica e jamais chegaram até nós. Muitos outros, embora tenham recebido registro textual, perderam-se no tempo por efeito de contingentes históricos diversos. Por essa razão, o leitor e o pesquisador de poesia hexamétrica arcaica deve se contentar com um corpus naturalmente reduzido de poemas que podem ser arranjados em cinco grupos, como segue: ao lado dos poemas canônicos da llíada e da Odisseia, da Teogonia e do Trabalhos \& Dias, associados às figuras igualmente canônicas de Homero e Hesíodo, e que constituem os dois principais conjuntos dentro desta tradição, temos a sorte de possuir os conjuntos dos Hinos Homéricos, os poemas do Ciclo Épico $\left({ }^{60}\right)$, e os poemas atribuídos às personalidades mitológicas de Orfeu e Museu $\left({ }^{61}\right)$.

Presentemente não há consenso científico a respeito do desenvolvimento diacrônico que estabelece essas cinco formas relacionadas, entretanto, diferentes, de poesia. Sabemos, por exemplo, que, devido à ausência de correlatos diretamente reconhecíveis em tradições de poesia indo-europeias, o hexâmetro dactílico é uma espécie de inovação grega, baseada em um ou mais versos "líricos" $\left({ }^{62}\right)$, mas não somos capazes de explicar do que na origem se tratava, qual era a matéria-prima de semelhante proto-hexâmetro, muito menos podemos esclarecer de que maneira a sua configuração original se desenvolve diacronicamente e se especializa naqueles cinco grupos distintos de poesia hexamétrica grega. Entretanto, há uma boa hipótese, elaborada por NAGY em uma variedade de artigos.

Para NAGY (2005, pp. 80-81) as formas cíclica, hesiódica e órfica do hexâmetro eram apresentadas dentro do contexto do festival ateniense das Panateneias, no século VI. Então, a forma cíclica, sob influência do teatro ateniense, teria se desenvolvido na forma homérica que conhecemos no século $V$, ao passo que sua forma original de narração épica teria assim se tornado periférica (a cíclica). As demais formas não-épicas de poesia hexamétrica, por sua vez, a poesia hesiódica, às vezes descrita como poesia didática, às vezes como cosmogônica, ou antropogônica, e a poesia órfica também seriam marginalizadas neste mesmo período de grandes mudanças. Desta forma, portanto, podemos também enxergar a disputa encenada

60 BURGESS (2005, p. 344), WERNER (2013, p. 22).

61 Ver BERNABÉ (1996-2007), especialmente a segunda parte desta edição. De acordo com NAGY (2005, pp. 8081), a forma órfica de poesia se tornou periférica ou marginal com o desenvolvimento da poesia homérica. Por essa razão o material que chegou até nós é extremamente reduzido e bastante complexo.

62 As melhores introduções sobre o assunto devem ser os seguintes trabalhos: KATZ (2010); MAGNELLI (1996); SCHMITT (1967); WATKINS (1995) e WEST (2007). As reconstruções mais importantes são (1) NAGY (1974), (1979), (1990), (2004); (2) WEST (1973a), (1973b), (1997); HASLAM (1976); (3) BERG (1978); HAUG \& WELO, (2001); HAJNAL (2003a), (2003b); e (4) TICHY (1981a), (1981b). 
por Agamêmnon e Estênelo, como uma disputa entre formas narrativas diferentes do epos arcaico $\left({ }^{63}\right)$.

Os poemas homéricos estabelecem rivalidade, portanto, com todo o passado heroico,

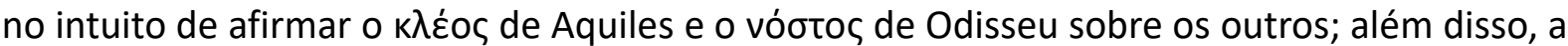
rivalidade acaba por se estender até mesmo para o interior dos próprios poemas homéricos, como entre Aquiles e Odisseu. A llíada por sua vez, compete com as narrativas de destruição e saque de cidades, dado que o poema não narra a destruição da cidade troiana; compete inclusive com a Odisseia, o qual atribui o arrasamento de Troia à astúcia de Odisseu, não à coragem de Aquiles. Assim, o viés iliádico, na sua rivalidade com a destruição de Troia por Héracles e de Tebas pelos epígonos (Estênelo e Diomedes), faz o argumento de Estênelo perder o debate.

\subsection{ISMARO}

O relato da captura e destruição da cidade dos Cícones encontra-se nos chamados Apologoi (Odisseia 9-12) e é narrado, da boca de Odisseu, em Odisseia 9. 39-66. Nesta parte do poema, a narrativa embutida mais longa de toda a épica arcaica, o itacense rememora os

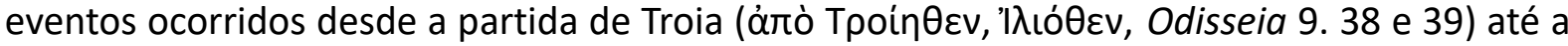
chegada à Ogígia (Odisseia 12. 447-450), o que, junto às "mentiras cretenses", estabelecem o status de Odisseu como cantor em Odisseia 11. 363-369 $\left({ }^{64}\right)$ : O herói narra onze aventuras: o encontro com os Lotófagos (9. 82-105), com o Ciclope (9. 106-566), com Éolo (10. 1-79), com os Lestrígones (10. 80-134), o primeiro encontro com Circe (10. 135-574), a Catábase (11. 1332, 385-640), o segundo encontro com Circe (12. 1-143), com as Sereias (12. 144-200), com Cila (12. 201-259), a Trinácia (12. 260-425), com Caríbdis (12. 426-446), com Calipso (12. 447450), dentre os quais a primeira é uma expedição militar contra os Cícones (9. 39-66). Porém, esta seção funciona muito mais como transição da "realidade militar troiana", para usar a expressão de Glenn Most $\left({ }^{65}\right)$. Em seu artigo seminal sobre o Apologoi, MOST $(1989$, p. 22) demonstra que as narrativas fabulosas encontram-se apartadas do restante da narrativa por

SAMMONS (2014, p. 307).

64 Ver DE JONG (2001, pp. 285-286).

$65 \operatorname{MOST}(1989$, p. 22). 
cenas duplicadas de tempestades de dois dias. A primeira tempestade, que marca o começo das andanças de Odisseu e encerra o episódio do saque da cidade dos Cícones, ocorre em Odisseia 9. 68-75; a segunda tempestade, que marca o desfecho das aventuras fabulosas de Odisseu, ocorre em 5. 291-298 e 388-389 $\left({ }^{66}\right)$. Além disso, o episódio dos Cícones não mostra as características específicas encontradas por BAKKER (2013, p. 23) nas outras dez narrativas.

Quanto aos Cícones, eles são mencionados duas vezes fora da Odisseia: no Catálogo das Naus são arrolados entre os aliados dos troianos, entre os contingentes dos Trácios e dos Peônios, todos provenientes pouco mais ou menos da mesma localidade, do lado europeu do Bósforo (Ilíada 2. 846). No outro trecho, Apolo se disfarça de comandante dessas tropas em uma cena com Heitor (llíada 17. 73).

Vejamos a passagem em questão; Odisseia 9. 39-66:

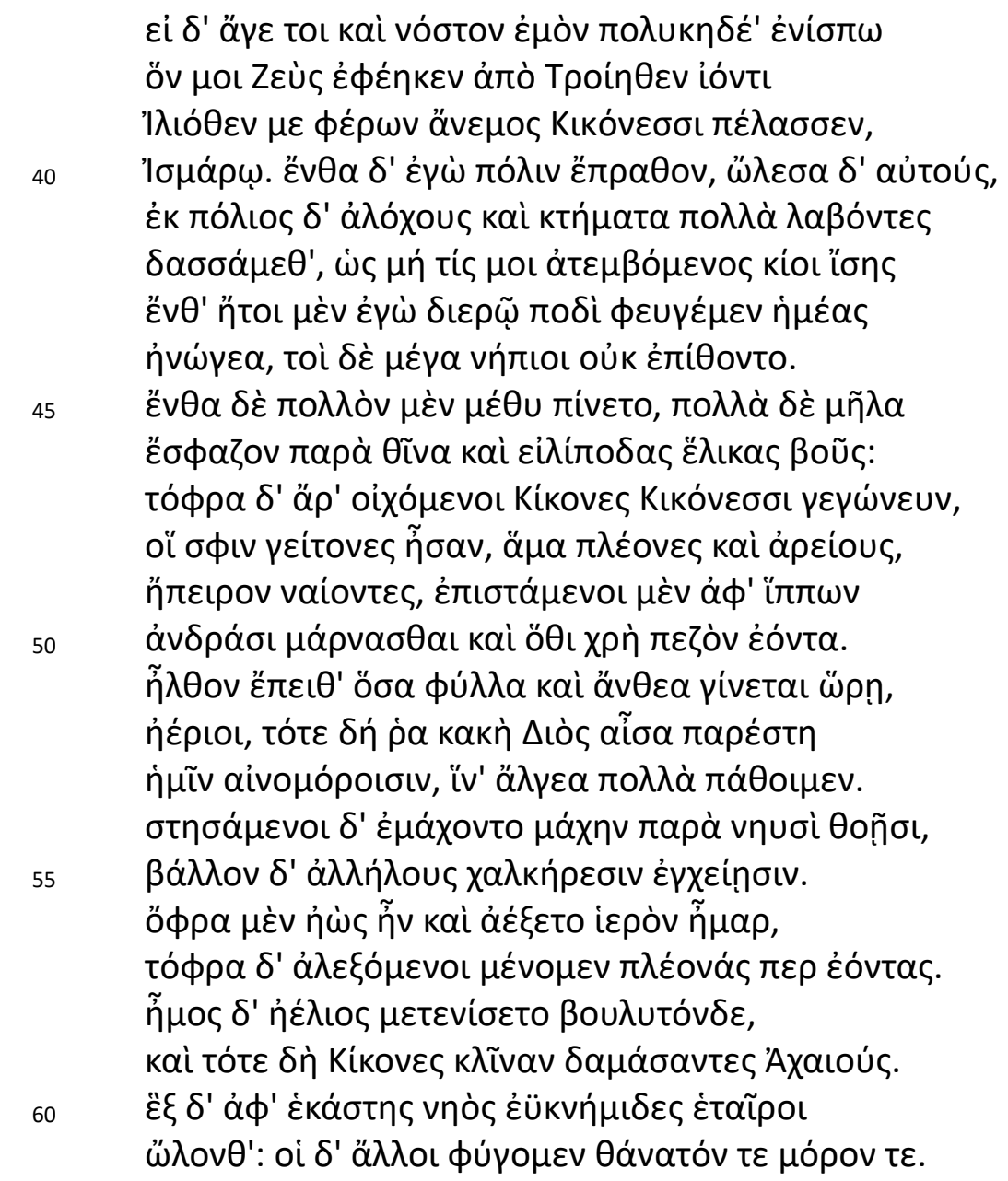

66 Devemos lembrar que parte da Odisseia é narrada de trás para adiante. É por este motivo que a segunda tempestade se acha em Odisseia 5, enquanto a primeira se acha em Odisseia 9. 


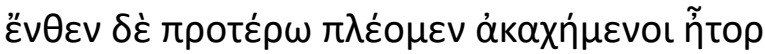

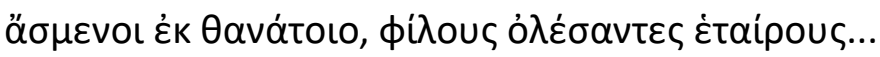

Mas contar-vos-ei o meu regresso muito doloroso:

o regresso que Zeus me impôs desde que parti de Troia.

De ílio fui levado pelos ventos até os Cícones,

até Ismaro: aí saqueei a cidade e chacinei os homens.

Da cidade levei as mulheres e muitos tesouros, que dividimos para que por mim ninguém visse sonegada a parte que lhe cabia.

Aí dei ordens no sentido de fugirmos com passo veloz;

mas eles, na sua grande insensatez, não quiseram obedecer.

Ali ficaram a beber muito vinho; e muitas ovelhas sacrificaram junto à praia e gado de chifres recurvos com passo cambaleante. Enquanto isso os Cícones foram chamar outros Cícones, que eram seus vizinhos, mas mais numerosos e valentes que eles. Viviam no continente e eram peritos em combater o inimigo, montados em cavalos e, se tal se afigurasse necessário, a pé. Chegaram em número igual ao das folhas e das flores na primavera, qual nuvem de guerreiros! Foi então que o destino malévolo de Zeus se postou ao nosso lado (homens terrivelmente condenados!), para padecermos muitas dores. Combateram e lutaram junto das côncavas naus; de ambos os lados voavam lanças de brônzea ponta. Enquanto era ainda de manhã e crescia em força o dia sagrado, repelimo-los sem dali arredar pé, embora eles fossem mais.

Mas quando o sol trouxe a hora de desatrelar os bois, então prevaleceram os Cícones, subjugando os Aqueus. E de cada nau pereceram seis camaradas de belas joelheiras, embora nós, os outros, conseguíssemos fugir à morte e ao destino. Daí navegamos em frente, entristecidos no coração, mas aliviados por termos escapado à morte...

Com já observamos, o trecho em que o saque de Ismaro, cidade dos Cícones, está inserido é o príncípio da narrativa embutiva mais extensa de toda a épica grega arcaica. Agora, Odisseu assume o papel de narrador e a forma como ele dá início a sua narrativa ecoa a protasis da

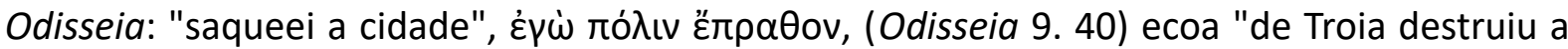

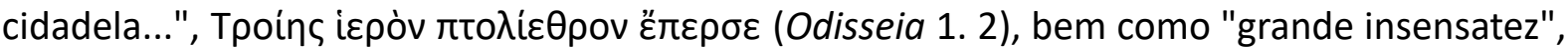

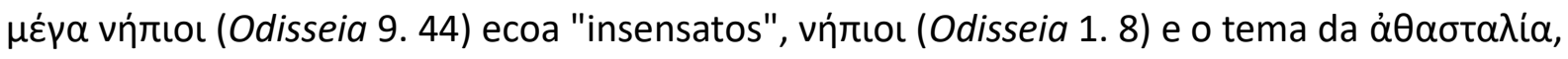
"loucura" (Odisseia 1. 7). Este começo da narrativa encena um padrão que se repete ao longo de toda a Odisseia. 
Nos primeiros versos do relato podemos depreender um certo roteiro de atividades de guerra que encontraremos em llíada 1. $366\left({ }^{67}\right)$ : a movimentação do exército: "de Ílio fui...

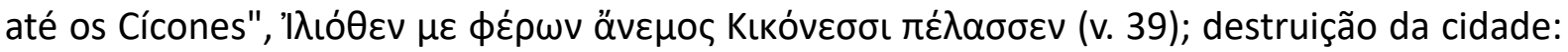

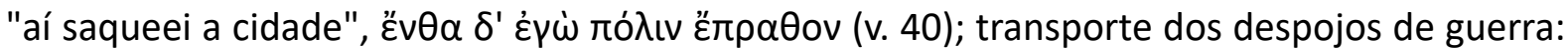

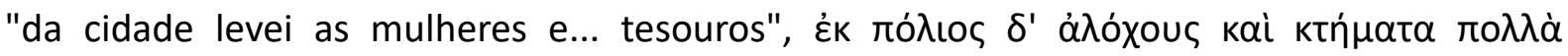

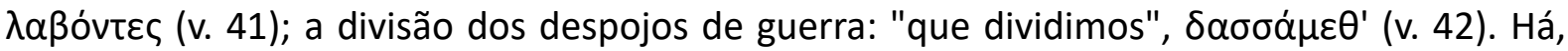
entranto, algumas variações relevantes nos detalhes: (1) podemos considerar rara a presença da movimentação do exército nesta forma de narrativa. Ela pode ser encontrada na narrativa da destruição de Tebas-sob-Placo em Ilíada 1. 366 ("fomos para Tebas", ழ’xó e no relato do saque e destruição de Troia pelas mãos de Héracles ("que outrora aqui veio",

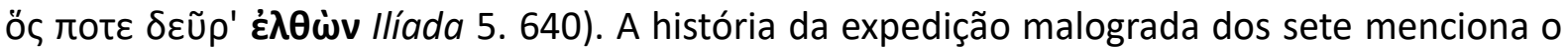
deslocamento do exército até um ponto próximo da cidade de Tebas: "Depois que partiram e estavam já a caminho, chegaram ao Asopo de fundos juncais reclinados na relva", oï $\delta^{\prime}$ ćrદì

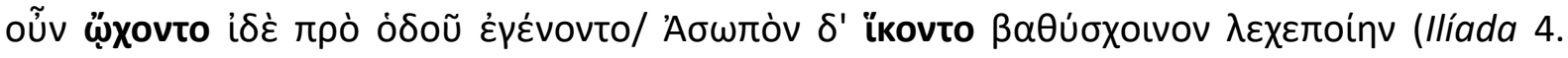
382-383). No entanto, é preciso observar que esse gênero de orientação, comum nas cenaspadrão de transporte marítimo, pode ser explicada como uma necessidade de uma narrativa de viagens, como é a narrativa odisseica em questão.

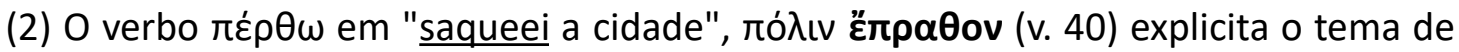
estudo. (cf. acima llíada 4. 406-407; llíada 5. 642). O trecho também faz menção a vítimas masculinas anônimas: "chacinei os homens", $\ddot{\lambda} \lambda \varepsilon \sigma \alpha \delta^{\prime}$ aủtoúc (v. 50), tal como encontramos

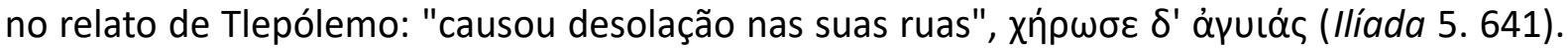
Porém, é preciso notar que, como adiante se verá, em vez dessas o narrador costuma mencionar uma figura importante para a cidade, um campeão ou soberano $\left({ }^{68}\right)$.

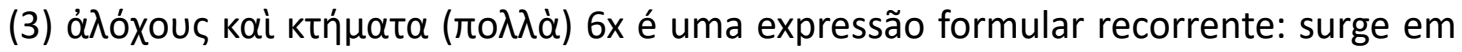
Ilíada 13. 626, Odisseia 9. 41, 14. 245, 21. 214. Só nesta passagem ela descreve despojos de guerra e mulheres cativas no contexto do saque de uma cidade. Em Odisseia 14. 245, a expressão surge para descrever a tranquilidade e o deleite da vida doméstica na companhia de filhos, esposa e riquezas: "durante um mês fiquei em casa comprazendo-me/ com os

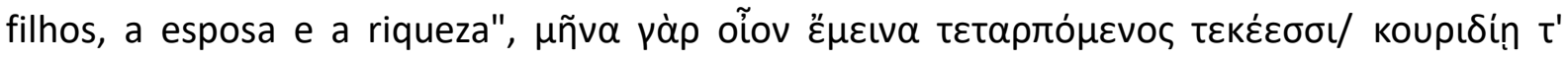

\footnotetext{
67 Infra, p. 74.

68 Infra, p. 96.
} 


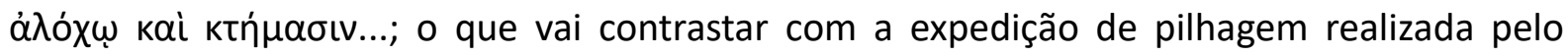
cretense/Odisseu. Esta expressão também é usada para descrever a tranquila vida doméstica em Odisseia 21. 214, cena em que o mendigo/Odisseu revela sua identidade a Eumeu e Filécio e promete Ihes dar "uma esposa, assim como propriedades/ e uma casa, construída perto da minha". A promessa de Odisseu reflete o desejo de Eumeu em Odisseia 14. 62-66. A vida nessas condições, segundo Eumeu, é a vida ideal e aquele soberano que for capaz de torná-la realidade deve ser considerado o soberano ideal (veja por exemplo Odisseia 7. 313314).

O paralelo mais próximo para 9.41 encontra-se em llíada 13. 626, em um discurso de Menelau: "Vós que me raptastes a esposa legítima e muitos tesouros/ sem razão levastes,

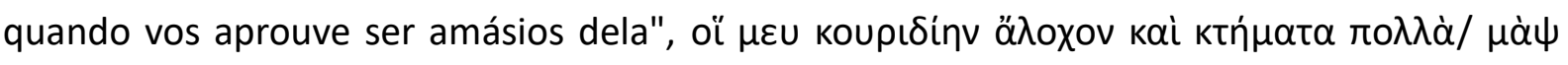

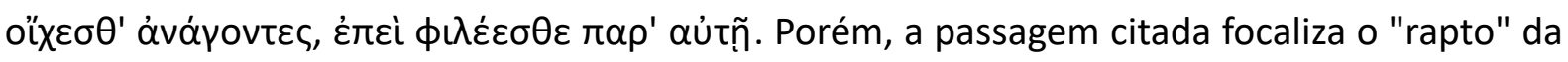
mulher da perspectiva daquele que sofre a ofensa. Não se trata da perspectiva do invasor como encontramos em Odisseia 9. 41. A expressão "esposa legítima e muitos tesouros" ou "riquezas" descreve a realidade doméstica da vida de Menelau, não os despojos de guerra amealhados no saque de uma cidade. Essa realidade, entretanto, é destruída pelo evento do rapto de Helena.

A possibilidade de adaptação dessa fórmula para o contexto de saque, ou de quebra da normalidade da vida, como prefigurada no discurso de Menelau, entretanto, se apresenta

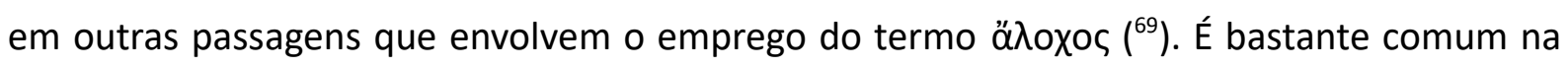
llíada que os guerreiros expressem a vontade sanguinária de matar ou escravizar as esposas de seus inimigos, sobretudo em exortações que imaginam a destruição da cidade de Troia, como por exemplo, diz Nestor: "ninguém se apresse a regressar para casa, antes que ao lado

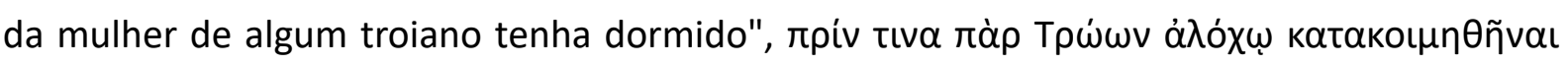
(llíada 2. 354-355) ou no juramento feito por Agamêmnon em llíada 3. 298-301. A linguagem

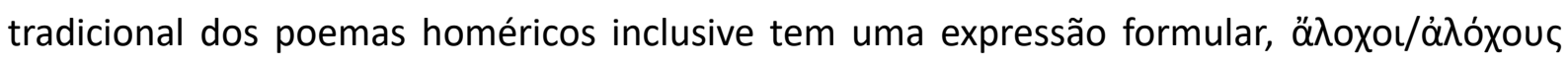

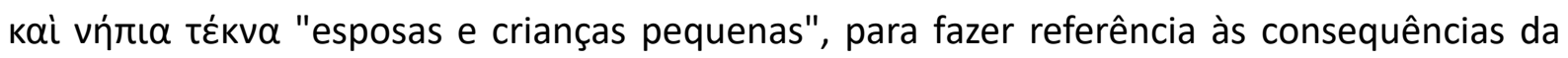
destruição de uma cidade para os seus residentes mais indefesos $\left({ }^{70}\right)$.

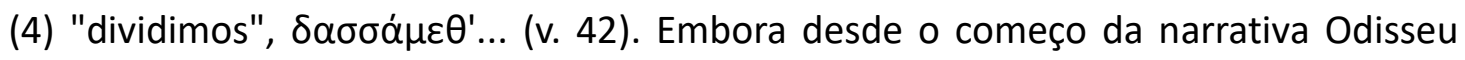

69 Ver CLARK (1940), para as acepções homéricas desta palavra. Cf. infra p. 85.

70 Ver WERNER (2008), sobre essa expressão. Cf. infra p. 128. 
tenha usado a primeira pessoa, por exemplo, "fui levado pelo vento", "daí saqueei a cidade", "chacinei os homens", "levei as mulheres", a divisão do butim aparece no plural. Na única passagem em que há claramente semelhante partilha, no relato da destruição da cidade de Tebas-sob-Placo encontramos a mesma mudança repentina: "fomos a Tebas", "saqueamos",

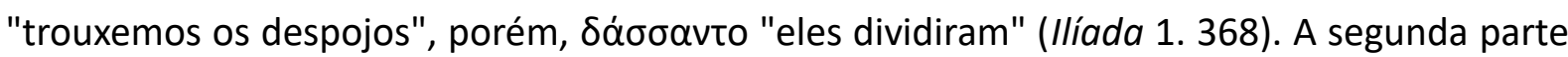
do verso, "para que por mim ninguém visse sonegada a parte que Ihe cabia", $\mu n ́$ tíc $\mu o \iota$

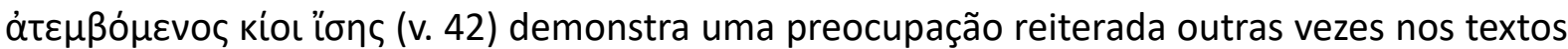
homéricos. Essa expressão formular pode ser encontrada tambem em Odisseia 9. 549, onde se descreve a partilha das cabras capturadas na caverna do ciclope Polifemo; e em llíada 11. 705 , onde se narra a partilha dos despojos resultantes da razia de gado que o jovem Nestor realiza com os epeios $\left({ }^{71}\right)$. Essas associações com atividades predatórias contra rebanhos coadunam com a interpretação de BAKKER (2013, pp. 37-38) para o significado da carne e do consumo de carne para a vida heroica e para o mito $\left({ }^{72}\right)$.

Geralmente, as micronarrativas de saque e destruição de cidades se encerram aqui. Diferente das narrativas embutidas em que se desenvolve a origem de um objeto ou pessoa com referência ao passado, como veremos adiante, a estrutura que observamos neste trecho parece a mesma das descrições panorâmicas (bird's eye view) de combate da llíada $\left({ }^{73}\right)$ : após resumir as condições gerais dos agentes envolvidos na ação imediata, o foco narrativo se volta para os personagens ou problemas específicos como a lente de uma câmera de cinema. Esse é o caso de muitos dos começos de cantos da llíada, como, por exemplo, 6. 1-5:

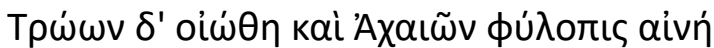

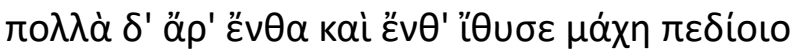

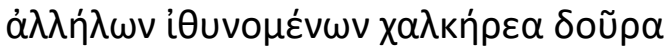

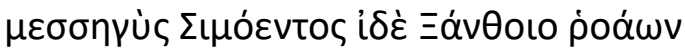

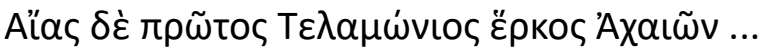

Só a Troianos e Aqueus competiu o fragor tremendo da refrega. E muitas vezes de um lado e do outro grassou a luta na planície, enquanto arremetiam um contra os outros com as brônzeas lanças, no terreno entre as correntes do Simoente e do Xanto.

71 Ver VIEIRA (2016, pp. 61-78) para uma análise do segundo episódio.

72 Ver BAKKER (2013, pp. 36-52).

73 VAN WEES (1997, pp. 673-674). 
Foi Ájax ...

Neste trecho da llíada está claro que o narrador se coloca de longe e observa todo o terreno ou várzea entre os rios Simoente e Xanto, onde localiza os exércitos dos aqueus e troianos. 0 combate não é visto da perspectiva dos agentes individuais em uma área restrita, mas antes da perspectiva panorâmica dos exércitos contrários envolvidos na batalha. A ação é resumida como uma espécie de cabo de guerra, em que um grupo prevalece sobre o outro durante um pequeno intervalo de tempo. Uma vez descritas as condições gerais em campo de batalha, o narrador passa, então, à descrição dos agentes individuais, fechando o foco de sua narrativa sobre Ájax.

No passo da Odisseia, o narrador descreve o saque de Ismaro em quatro versos, para em seguida voltar-se aos protagonistas da ação e ao tema principal deste episódio. A "grande

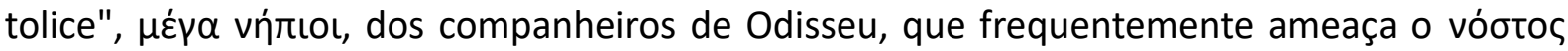
seguro do herói. Os companheiros não dão ouvidos ao seu comandante e entregam-se a um grande banquete: "ficaram a beber muito vinho; e muitas ovelhas sacrificaram/ junto à praia

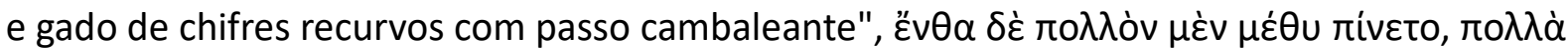

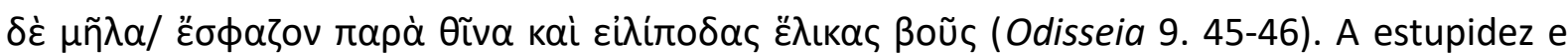
insubordinação da soldadesca permite aos Cícones convocar outros Cícones e dar um contragolpe. A narrativa daqui em diante retoma as descrições panorâmicas de guerra da llíada

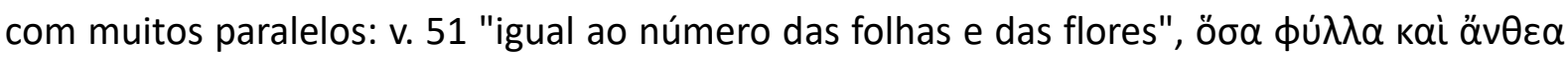
үívetaı $\ddot{\omega} p n$ = Ilíada 2. 468; vv. 54-55 "combateram e lutaram junto das côncavas naus; de

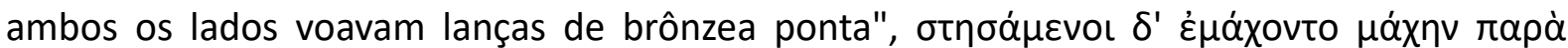

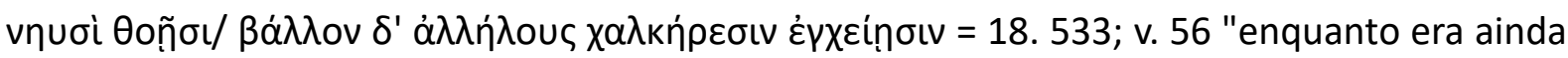

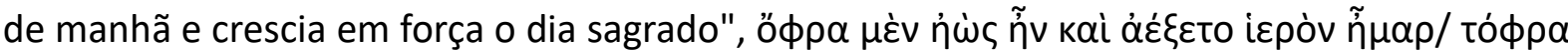
= 11. 84-85 (= 7. 66-67); v. 58-59 "mas quando o sol trouxe a hora de desatrelar os bois...",

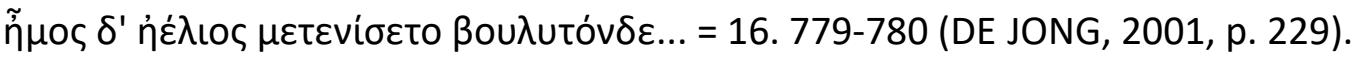

Mesmo depois de saqueada a cidade, dos despojos terem sido recolhidos e divididos, o exército sitiante amarga uma derrota em campo de batalha, em uma muito surpreendente reviravolta. Os vizinhos Cícones são convocados para o combate, a batalha se desenrola ao longo do dia, até que as forças dos sitiados e seus aliados conseguem expulsar os invasores. 
O saque de Ismaro é relatado também em outras duas passagens da Odisseia. Uma delas surge em Odisseia 9, em uma cena de transição para uma nova aventura. Odisseu e os soldados desembarcam em uma ilha e acampam (Odisseia 9. 150). No dia seguinte fazem o reconhecimento do local e caçam cabras montesas. Então passam o dia banqueteando-se até que percebem, em uma ilha na vizinhança, fumaça, vozes de pessoas e rebanhos (9. 167). Esta menção a Ismaro, assim como muitas das outras passagenes estudadas, está associada a um item específico do espólio de guerra; Odisseia 9. 161-167:

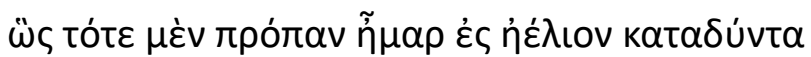

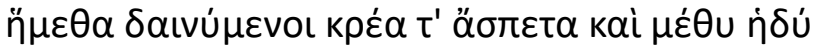

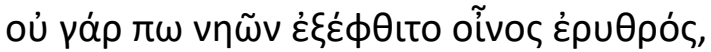

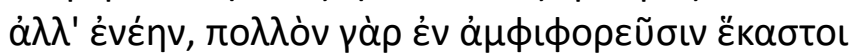

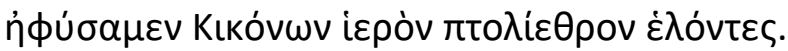

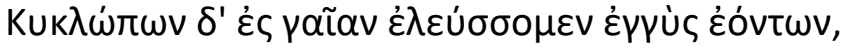

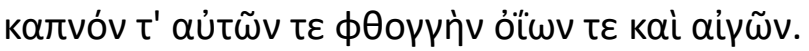

Todo o dia, até o pôr do sol, nos banqueteamos, sentados a saborear a carne abundante e o doce vinho. Pois das naus não se esgotara ainda o rubro vinho: tínhamos suficiente porque cada tripulação ficara com muitos jarros quando saqueamos a cidade dos Cícones. Olhamos então para a terra dos Ciclopes, ali tão perto, e vimos fumaça a subir; ouvimos vozes, deles e do rebanho...

Odisseu e os companheiros passam o dia a comer carne e beber vinho. O narrador/Odisseu, em uma observação realista, menciona que as provisões de vinho ainda não se esgotaram graças às jarras muito numerosas saqueadas na cidade dos Cícones (9. 165). A referência ao

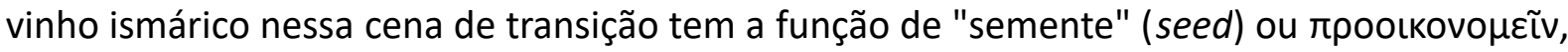
uma forma de prolepse que incorpora na narrativa uma informação que mais adiante será retomada e ganhará relevância, tornando o evento narrado adiante mais plausível $\left({ }^{74}\right)$. Tal como nas demais passagens analisadas, a procedência das jarras de vinho ismárico é, por meio de uma oração temporal, tornada explícita em meio hexâmetro: "capturamos a cidade

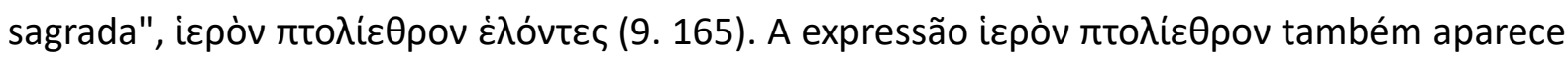

74 Ver DE JONG (2001, p. 235, xvii), sobre essa ferramenta narratológica. 


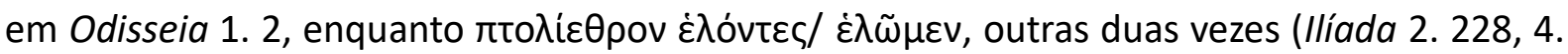
239).

O episódio dos Cícones é mencionado uma terceira vez na Odisseia, porém, uma vez que não há menção à destruição, à captura da cidade ou semelhante, muito menos emprego dos verbos que relacionamos à referencialidade do tema, não deve ser considerado. Nesta passagem, Odisseu, pela quarta vez na Odisseia, relata suas andanças para um interlocutor; desta vez trata-se de Penélope. O episódio é contado em um verso: "começou por contar

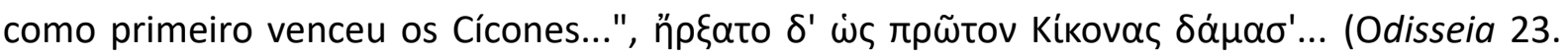

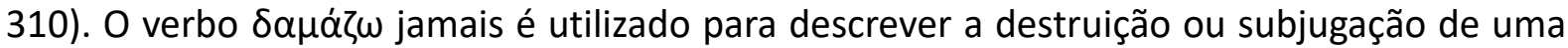
cidade ou do povo aí residente nos poemas. Em geral, quando usado com objeto direto no

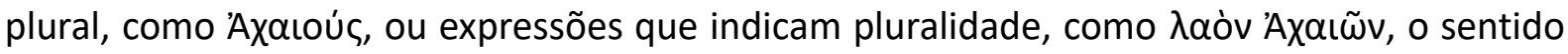
é sempre de "vencer, derrotar, subjugar" o inimigo $\left({ }^{75}\right)$.

\section{$2.4 N E ́ R I C O N$}

Encontramos na Odisseia menção ao saque de Néricon. A cidade é descrita pela

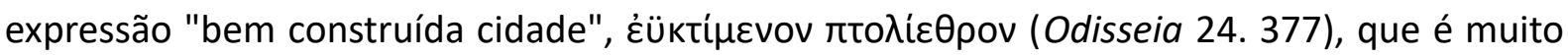
usada nos poemas e tem valor genérico Ilíada 2. 501, 506, 546, 569; depois em 4. 33; 8. 288; 21. 433; Odisseia 8. 283; 24. 377. No verso seguinte, a descrição de Néricon é especificada pelo aposto: "[promontório] do continente", "[na costa] do continente", áktìv n் descreve sua posição em relação a Ítaca e Cefalênia em geral. É uma cidade bastante obscura que só vai ser mencionada outra vez em Tucídides (3.7.4).

A passagem se encontra na conclusão de uma cena-padrão de banho, em Odisseia 24. 365-383 $\left({ }^{76}\right)$. Esta cena contém os seguintes elementos: (1) entrar na banheira, (2) lavar-se, (3) ungir-se, (4) vestir-se, (5) sair da banheira, (6) opcional: aparentar um deus e (7) levantarse. Muito comum na Odisseia, por estar intimamente associada à narrativa de viagem (3. 468, 4. 48, 8. 450-456), a cena-padrão de banho costuma sinalizar a transição de situações de perigo para contextos de segurança e tranquilidade. Telêmaco (Odisseia 17. 87-90),

75 Ver. VERMEULE (1981, pp. 101-102);

76 Ver AREND (1933, pp. 124-126); KIRK (1990, p. 154); HAINSWORTH (1993, p. 208); M. W. EDWARDS (1992, p. 306); HEUBECK (1988, p. 189); HEUBECK (1989, p. 63); DE JONG (2001, pp. 87-88); RICHARDSON (1992, p. 338); M. W. EDWARDS (1991, p. 187). 
Odisseu (23. 163) e Laerte (24. 370) se banham após chegar em casa. Telêmaco, depois de escapar da emboscada dos pretendentes; Odisseu depois de executá-los; e Laerte, no trecho sob exame, depois de um período de negligência e sofrimento desmedidamente longos $\left({ }^{77}\right)$. Assim, Laerte (2) é lavado e (3) ungido pela criada siciliana (Odisseia 24. 365-366a); (4) recebe uma muda de roupas de boa qualidade (367a); (5) é embelezado por Atena (367b369); e (5) deixa a banheira (370a).

Odisseu, então, ao ver Laerte "mais alto do que antes e mais musculoso", $\mu \varepsilon i ́ \zeta o v \alpha ~ \delta^{\prime}$

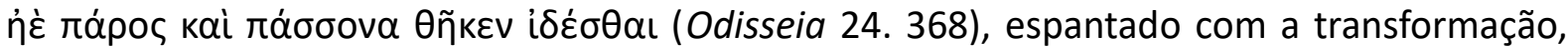
comenta: "ó pai na verdade um dos deuses que são para sempre, te deu uma beleza e uma

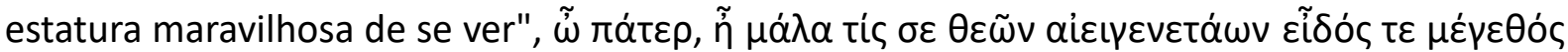
$\tau \varepsilon$ ả $\mu \varepsilon i$ vova $\theta \tilde{n} \kappa \varepsilon v ~ i \delta \varepsilon ́ \sigma \theta \alpha \iota ~(24 . ~ 373-374)$. Essa é a deixa para Laerte fazer o seguinte discurso em Odisseia 24. 376-382:

375

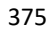

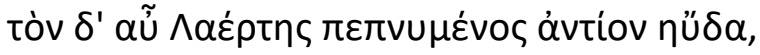

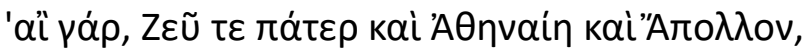

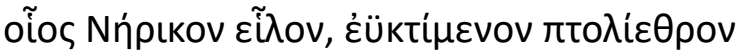

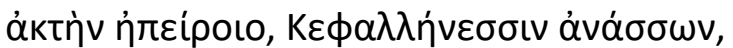

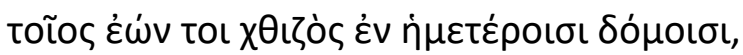

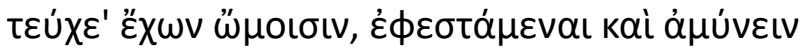

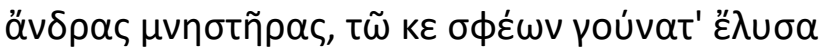

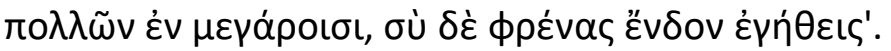

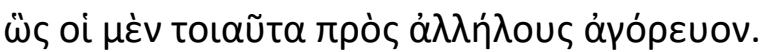

A ele deu resposta o prudente Laertes:

'Prouvera - ó Zeus pai!, ó Atena!, ó Apolo! - que com força igual à que tinha quando conquistei Néricon, a bem construída cidade no continente, quando era soberano dos Cefalênios prouvera que com essa força eu tivesse estado ontem contigo no nosso palácio, com as armas nos ombros, para atacar os pretendentes! Teria afrouxado os joelhos a muitos deles na sala de banquetes, e o teu coração ter-se-ia regozijado!' Foram estas as coisas que disseram um ao outro...

Laerte começa sua resposta com um desejo contrafactual, introduzido pelo verso: "prouvera

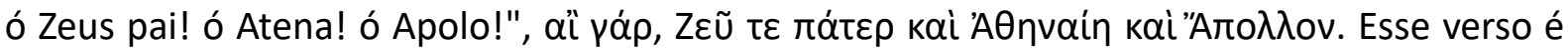
77 DUÉ \& EBBOTT (2010, p. 379). 
usado nove vezes na tradição hexamétrica arcaica para introduzir uma forma muitas vezes impossível de desejo ou de aspiração nostálgica. Das quatro ocorrências na llíada, três estão intimamente relacionadas ao tema da captura e destruição de cidades (Ilíada 2. 371, 4. 288, 16. 97). Constituem um tipo de prolepse que, na lógica interna da llíada, prefiguram o saque da cidade troiana. O quarto exemplo é um paralelo perfeito para a fala de Laerte: Trata-se do discurso de Nestor em llíada 7. Neste episódio Heitor desafia o exército grego a escolher um campeão para enfrentá-lo em um duelo ritual. Diante da hesitação dos seus companheiros, Nestor narra um paradeigma, um exemplo de comportamento da sua juventude: ó Zeus pai! ó Atena! ó Apolo, diz ele, "quem dera ... eu fosse tão jovem como quando... combatiam

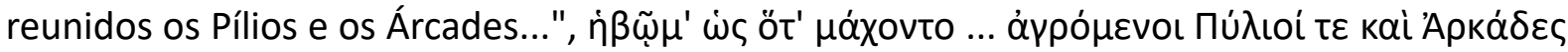

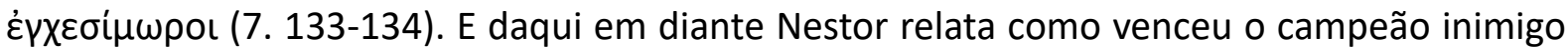
Ereutálion em combate singular (7. 136).

Na Odisseia encontramos exemplos semelhantes, mas um pouco diferentes: Menelau expressa o desejo, repetido depois por Telêmaco (Odisseia 4. $341=17.132$ ), de que Odisseu retornasse para punir os pretendentes com a mesma "capacidade" que ele mostrou em um evento específico do passado: uma luta de boxe em que o herói enfrentou um Filomelides na ilha de Lesbos e saiu vitorioso. Em Odisseia 7 .311-316 Alcínoo externa o desejo irrealizável, que ele mesmo sabe ser irrealizável, de que Odisseu permaneça na ilha junto aos Feácios $\left({ }^{78}\right)$; em 18. 235 Telêmaco expressa o desejo de que os pretendentes perdessem "a força dos seus membros", como o mendigo Iro. Esses paralelos são diferentes das passagens de Nestor e Laerte porque (1) os desejos são projetados sobre terceiros; (2) com a exceção de Odisseia 4. 341 (= 17. 132) não recuperam eventos do passado; (3) estão fora do contexto militar de destruição de cidades e do campo de batalha.

Tal como Nestor, que vai buscar na sua juventude uma façanha que descreva melhor as suas habilidades marciais, também Laerte escolhe um episódio específico: a tomada da cidade de Néricon: "quando conquistei Néricon a bem construída cidade", Nńpıкov عĩ̄ov,

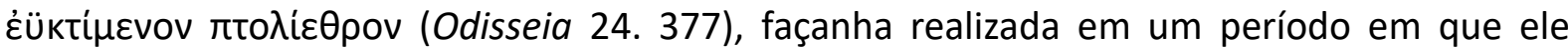

78 H. CLARKE (1967, p. 54) coloca o problema da seguinte forma: "their life has no promise, no potentialities, no dynamis; to remain with them would drain Odysseus of his heroism by depriving him of any chance or need of action it would be a living death" ("a vida deles não tem futuro, nem tem potencialidades, não tem dinamismo; permanecer com eles consumiria o heroísmo de Odisseu ao privá-lo de qualquer oportunidade ou necessidade de ação, sua existência seria como a de um morto-vivo"). 
reinava sobre os cefalênios. Entretanto, a escolha de Nestor é um exemplo paradigmático cujo objetivo é enviar uma mensagem aos seus ouvintes (soldados que hesitam em enfrentar Heitor) para que eles repensem sua conduta diante dos fatos presentes. No caso de Laerte, a chacina dos pretendentes já aconteceu, não existe mensagem embutida na sua analepse, até onde podemos dizer $\left({ }^{79}\right)$.

Dos elementos atestados até aqui nas narrativas de saque e destruição de cidades, a menção brevíssima à tomada de Néricon contém apenas um, a presença do verbo "tomar",

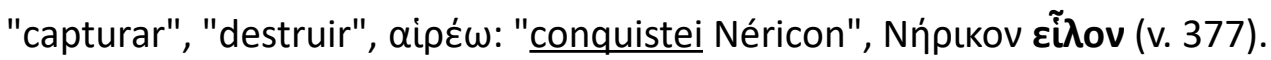




\section{OS DESPOJOS}

\subsection{TEBAS-SOB-PLACO}

A cidade de Tebas Hipoplácia ou Tebas-sob-Placo, é mencionada pela primeira vez em Ilíada 1. 366. Depois do desentendimento entre Aquiles e Agamêmmnon (Ilíada 1. 53-305), Criseida é levada para Crises e Briseida é levada da tenda de Aquiles. Sentindo-se injustiçado, um melancólico Aquiles dirige-se para a praia e chama pela mãe, a nereida Tétis. A cena é importante: a conversa entre mãe e filho selará o destino do exército aqueu, especialmente o de Pátroclo, além de introduzir um dos temas principais da llíada, o tema da imortalidade $\left({ }^{80}\right)$. Em termos formais, a cena é arquitetada como uma cena-padrão de prece: a fala de

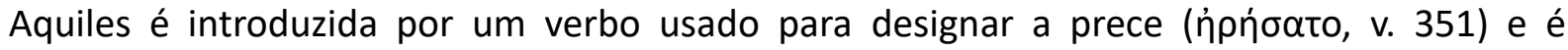

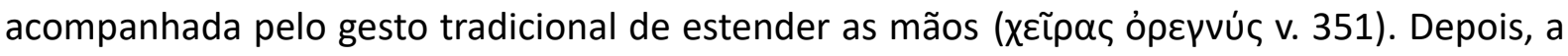

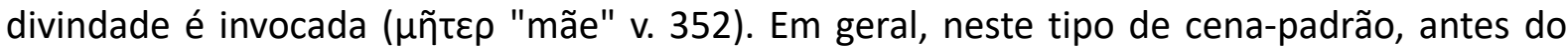
suplicante avançar o seu pedido, ele faz menção a favores prestados ao deus no passado ou promete prestar favores no futuro, ou, ainda, menciona a ajuda prévia da divindade em uma ocasião. O narrador, no entanto, omite este estágio da cena-padrão de prece porque esta narrativa, além de encenar a relação entre divindade e homem mortal, também encena a relação entre mãe e filho. Além disso, o pedido assume a forma de protesto: "honra deveria

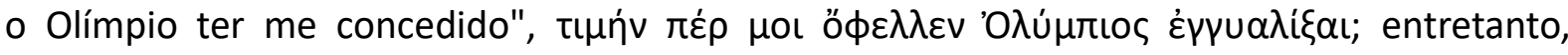

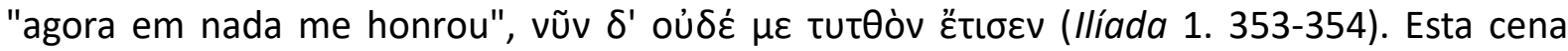
costuma se concluir com um quinto e último componente: a conclusão do discurso com um verbo usado para expressar prece ou o formular üs фáto, "assim disse" (v. 357) e a resposta da divindade $\left({ }^{81}\right)$. Porém, o narrador utiliza neste trecho um recurso comum em Homero: a amplificação. Em vez de a divindade simplesmente responder negativa ou positivamente ao pedido do suplicante, nesta cena em específico, observamos Tétis responder com outra pergunta, pedindo ao filho detalhes da situação, dando oportunidade para que o narrador

80 M. W. EDWARDS (1988, p. 183).

81 A. T. EDWARDS (1980, pp. 17-19); DE JONG (2001, p. 59); MORRISON (1991). 
elabore um resumo da ação que ocorreu até esse momento no poema (vv. 366-392) ${ }^{82}$ ).

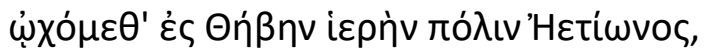 \\ 367

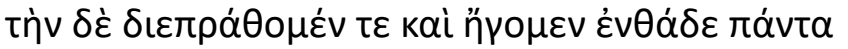

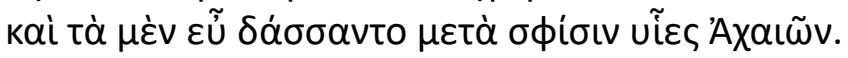

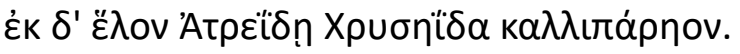

Fomos para Tebas, a sagrada cidade de Eécion:

367 saqueamo-la e de lá trouxemos todos os despojos;

bem os dividiram entre si os filhos dos Aqueus.

Para o Atrida escolheram Criseida de lindo rosto.

Este breve resumo da ação apresenta claramente quatro atividades beligerantes essenciais:

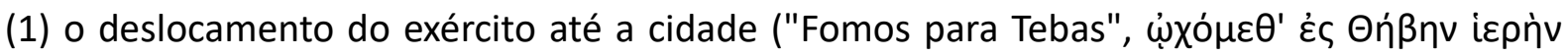

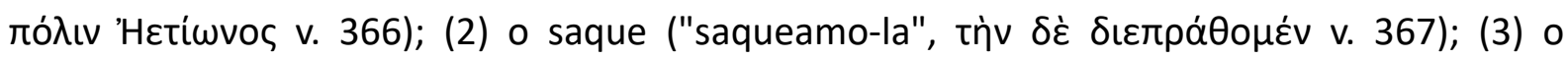

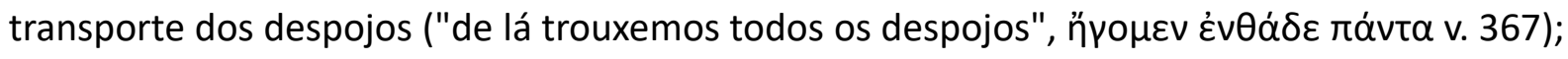
e finalmente (4) a justa partilha dos despojos de guerra, ("bem os dividiram entre si os filhos

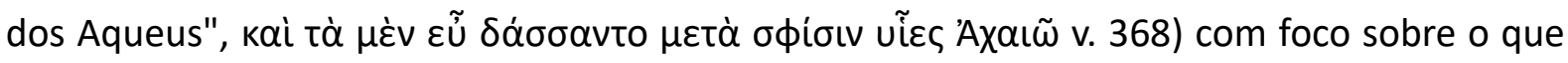

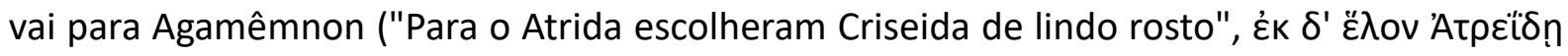

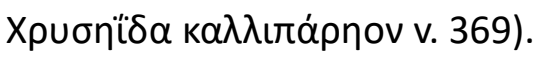

A primeira atividade é caracterizada pelo emprego do verbo oľxo $\mu \alpha \iota$ que designa o deslocamento do exército. O verbo é não-marcado, ou seja, não se aplica só a tropas, mas a uma variedade de agentes como, por exemplo, viajantes. Ele reaparece nesta posição, na primeira pessoa do plural, seguido do nome da cidade para onde o agente se direciona, só

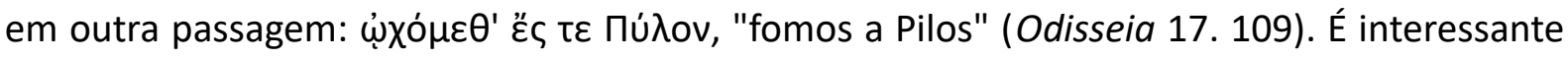

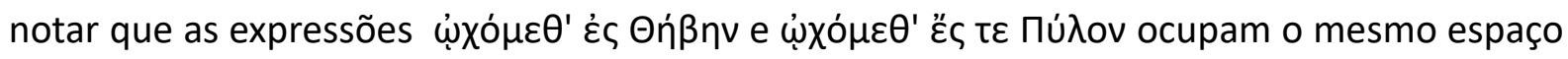

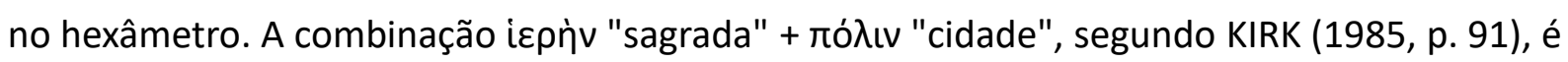
incomum na linguagem especial da épica, muito embora o adjetivo "sagrado" seja amiúde usado para caracterizar cidades, tal como Troia (llíada 7. 20) ou Zeleia (Ilíada 4. 103). A

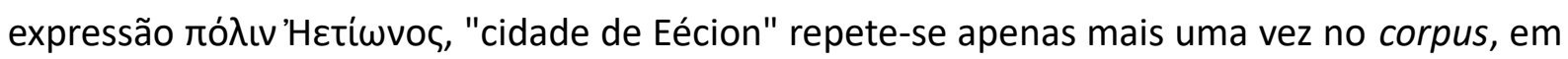

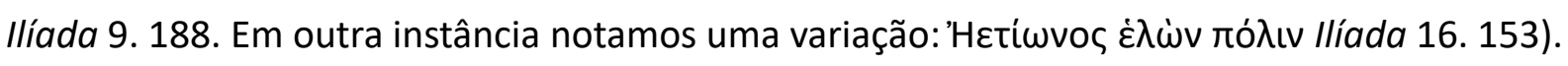

Esta informação é nova, não tinha aparecido em llíada 1 até o presente momento: 82 M. W. EDWARDS (1988, p. 183). 
Tebas-sob-Placo era governada por Eécion, pai de Andrômaca, esposa de Heitor. É bastante

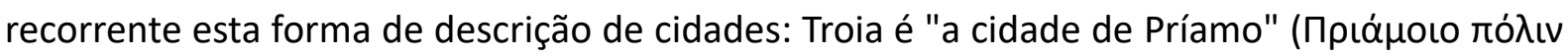

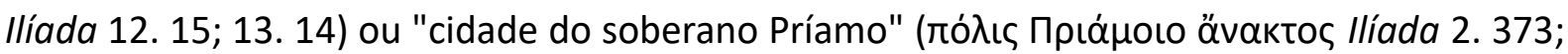

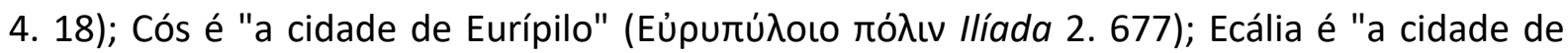

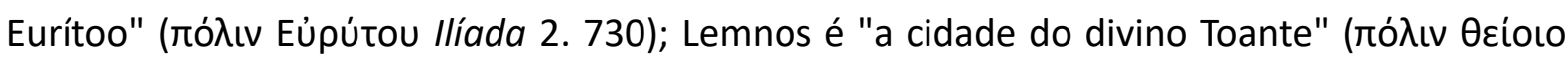

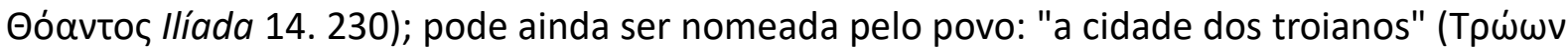

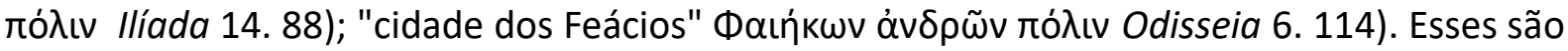
membros da aristocracia ou realeza local e governantes, ou os melhores de seus guerreiros defensores ou ambos. É nova também a informação de que Criseida foi capturada em Tebas, não em Crisa. De acordo com KIRK (1985, p. 91) o escoliasta bT registra ad llíada 1. 366 que Atena impede a destruição e saque de Crisa por Aquiles, porém ele arrasa a cidade de Tebas, onde Criseida estava em visita à esposa de Eécion para a execução de uma atividade ritual. O fato de detalhes sobre a destruição de Tebas-sob-Placo serem narrados em vários trechos da Ilíada (dentre os quais, 2. 688-694; 6. 414-428; 9. 185-190; 16. 148-154), e ainda em poesia não-homérica, como a Cípria (arg. 161-162 Severyns 23-24 West), sugerem que esta história era um tema conhecido da épica tradicional arcaica $\left({ }^{83}\right)$.

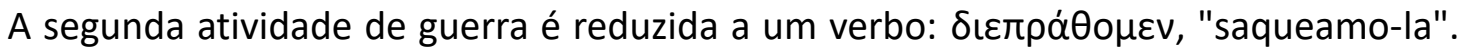
Já observamos que $\delta \iota \alpha \varepsilon \varepsilon \rho \theta \omega$ "arrasar" está relacionado ao objeto de estudo desta tese: são treze ocorrências deste verbo em épica arcaica, todas associadas à destruição de cidades $\left({ }^{84}\right)$.

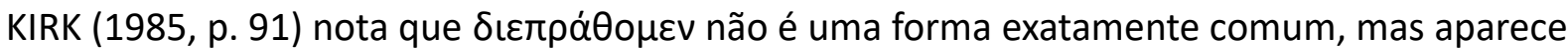
parcialmente no que ele chama de "compostos" quatro vezes na llíada; o autor também cita

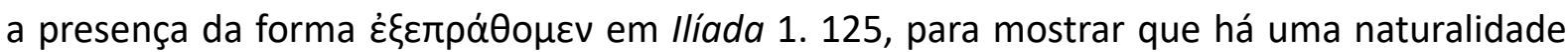
na linguagem observada neste trecho como um todo, ainda que limitada. Entretanto, outros comentadores como PULLEYN (2000, pp. 217-218), ignoram ou não reconhecem importância nessas observações. Não encontramos detalhes esclarecedores na forma muito econômica como são narradas as demais atividades bélicas do transporte e da partilha dos despojos da cidade saqueada. Entretanto, existem outras passagens na llíada que contam outros detalhes sobre este episódio como, por exemplo, llíada 9. 185-191:

83 KIRK (1990, p. 211); DUÉ (2011a, pp. 861-862); idem (2002, pp. 62-63); CURRIE (2015, p. 293).

84 Ver llíada 1.367; 4.53; 4.55; 7.32; 9.46; 9.532; 18.511; Odisseia 3.130; 8.514; 11.533; 13.316; 15.384. 


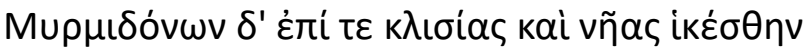

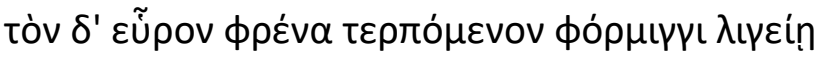

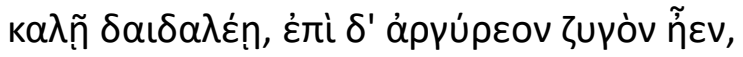

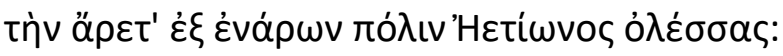

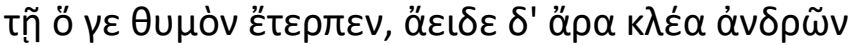

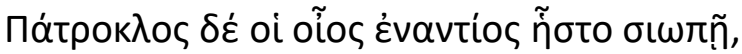

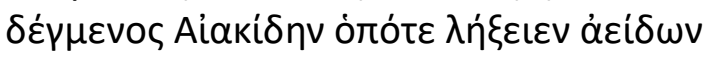

Chegaram às naus e às tendas dos Mirmidões e encontraram-no a deleitar-se com a lira de límpido som, bela e bem trabalhada, cuja armação era de pratalira que ele arrebatara depois de destruir a cidade de Eécion. Com ela deleitava o seu coração, cantando os feitos gloriosos dos homens; e só Pátroclo estava sentado à sua frente, ouvindo em silêncio, à espera que o Eácida parasse de cantar.

A "cidade de Eécion" é a forma como Tebas-sob-Placo é referida neste trecho. O episódio é, naturalmente, bastante conhecido: a famosa embaixada enviada por Agamêmnon, composta por Odisseu, Ájax e Fênix, para tentar convencer Aquiles a retornar para o combate. O trecho supracitado compreende os primeiros elementos da cena-padrão de visita ou hospitalidade:

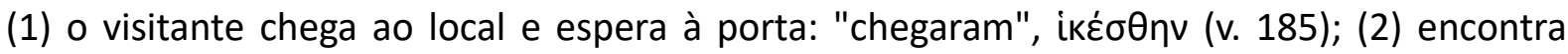
quem procura, que pode receber uma descrição: "encontraram-no", tòv $\delta$ ' عũ pov (v. 186); (3) o anfitrião se levanta e recebe os visitantes com uma saudação; etc. ${ }^{85}$ ). Em Ilíada 9. 185191, Odisseu, Ájax e Fênix encontram Aquiles e Pátroclo nas tendas dos Mirmidões. Os Mirmidões praticam exercícios e disputam jogos atléticos; Aquiles tange a lira. Ele canta um tema épico: "feitos gloriosos dos homens", к $\lambda \varepsilon \dot{\alpha} \alpha \dot{v} \delta \rho \tilde{\omega} v$ (Ilíada 9. 189), em um instrumento musical que para ele é singular, um espólio de guerra. A cena é descrita por autores como "espantosa e inesperada" (M. W. EDWARDS, 1988, p. 220) ou "uma surpresa" (GRIFFIN, 1995, p. 98). Com efeito, ela parece ressaltar um brusco contraste: o herói que deveria realizar façanhas de guerra gloriosas e, a bem da verdade, é o mais apto no poema para semelhantes empresas, encontra-se meramente a cantá-las; e ele retira prazer disso: "deleitando-se",

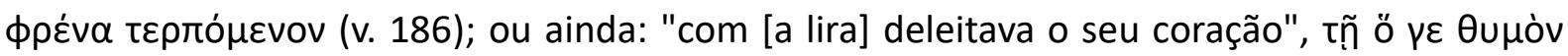

85 Ver M. W. EDWARDS (1975, pp. 63 ss.); (1992); GRIFFIN (1995, p. 98) e HAINSWORTH (1993, pp. 84-85), para esse tipo de cena-padrão. 


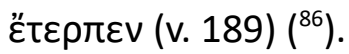

Neste extrato, a menção à destruição de cidades acha-se embutida na descrição de

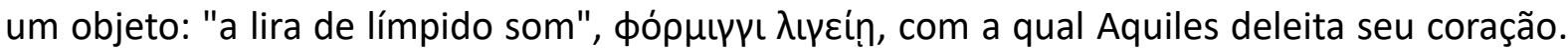
A descrição deste objeto é breve, ocupa apenas dois versos da passagem, os versos 187-188. O verso 187 é um Gesetz der wachsenden Glieder, também chamado de tricolon crescendo: o

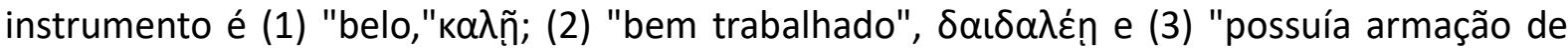

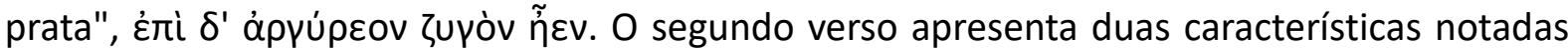
na passagem de Ilíada 1.366 comentada acima: o estabelecimento de relação entre a cidade saqueada e um personagem importante, governante, membro da realeza ou campeão, na

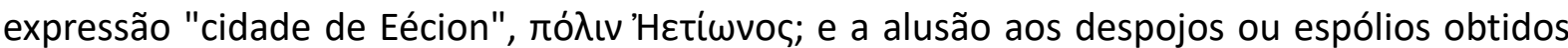
na conquista da cidade. O que em Ilíada 1. 366-368 era apenas uma expressão generalizante,

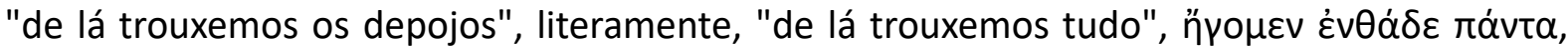
neste extrato do poema o butim de Tebas-sob-Placo se reverte em um objeto específico.

Além da lira de límpido som, encontramos a cidade de Eécion interrelacionada a dois outros objetos, também despojos de guerra e também propriedades de Aquiles, na llíada: o cavalo Pédaso (Ilíada 16. 148-154) e um pedaço de ferro (llíada 23. 826-829). A alusão ao tema da destruição e saque de cidades, também nesses casos, vem embutida dentro de uma descrição, tal como registrado em Ilíada 9. 185-191. Vejamos a primeira passagem. Ela se encontra no contexto da aristeia de Pátroclo no canto 16 da llíada, dentro da cena-padrão de armamento (Ilíada 16. 101-256). Como as cenas de armamento de Páris (Ilíada 3. 330-339) e Agamêmnon (Ilíada 11. 16-46), a cena de Pátroclo apresenta a mesma sequência tradicional envolvendo caneleiras, loriga, espada, capacete, escudo e lança, todavia, com conhecidas particularidades. A primeira é a presença, opcional, da preparação dos cavalos. Além disso, o poeta menciona que a loriga não é dele, mas de Aquiles. Depois, lembra ainda que Pátroclo é incapaz de envergar a lança de Aquiles, que era de Peleu. O armamento do herói, diferente das outras aristeias, não reluz e um cavalo mortal, Pédaso, é colocado como guia dos cavalos divinos. Estes detalhes sugerem que Pátroclo não está à altura da façanha de guerra para a qual está se equipando. Pédaso, que morre em combate, mostra, com enorme eficiência, as

86 ver FRANKLIN (2011, pp. 663-665), idem (2006), WEST (1992), YOUNGER (1998). 
limitações trágicas de Pátroclo $\left({ }^{87}\right)$. A cena de armamento é uma cena simbólica $\left({ }^{88}\right)$. Aqui está o trecho, a preparação dos cavalos, que nos interessa:

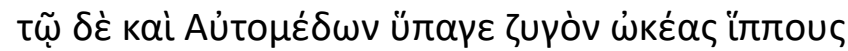

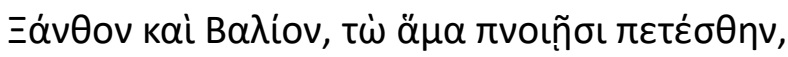

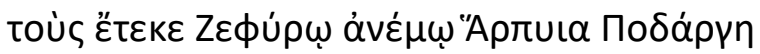

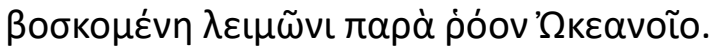

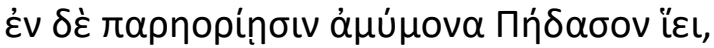

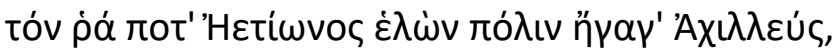

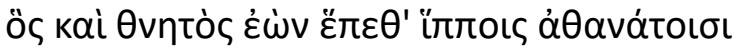

Para ele atrelou então Automedonte os corcéis velozes, Xanto e Bálio, que voavam rápidos como os ventos: gerara-os para o vento Zéfiro a harpia Podarga, quando pastava nas pradarias perto da corrente do Oceano. Aos tirantes laterais atou outro cavalo, o irrepreensivel Pédaso, que Aquiles trouxera depois de saquear a cidade de Eécion: cavalo que, mortal embora fosse, acompanhava corcéis imortais.

Pédaso recebe uma breve descrição em dois versos. No verso 153 o narrador descreve Tebassob-Placo pela forma comum "cidade de Eécion". Dois verbos caracterizam o tema do saque e destruição de cidades: o verbo aipéw "capturar, destruir" e o verbo ä $ү \omega$ "trazer", também

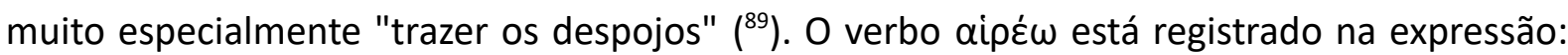

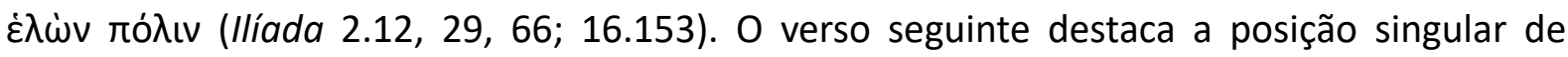
Pédaso, um cavalo mortal servindo de guia a uma parelha divina: "mortal embora fosse,

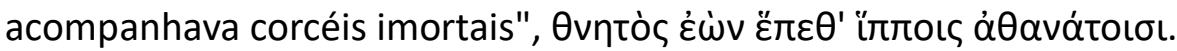

O terceiro objeto, um pedaço de ferro, espólio da guerra contra a cidade de Eécion, é citado em llíada 23. 826-829. O contexto da passagem são os torneios atléticas realizados em honra do recém-falecido Pátroclo. O pedaço maciço de ferro é selecionado por Aquiles como prêmio para o homem que conseguir arremessá-lo mais longe. Em contextos de torneios, ouvimos falar nos poemas homéricos de lançamento de disco (Ilíada 2. 774); Odisseu, na ilha dos Feácios, compete nesta modalidade contra os jovens nativos (Odisseia 8. 186-193). Ele

89 Ver VIEIRA (2016, p. 25) para o valor dos cavalos enquanto commodities. 
arremessa discos de pedra (Odisseia 8. 190). O levantamento e arremesso de pesos e pedras, embora ocorram às vezes na poesia épica homérica, não constituem modalidades esportivas propriamente ditas; daí a singularidade dessa competição em específico. O pedaço de ferro concedido como prêmio era o bastante para atender às necessidades de um fazendeiro por cinco anos, segundo Aquiles (Ilíada 23. 832-835). Isso sugere duas coisas relevantes: o corpo extraordinário do material e o seu valor extravagante $\left({ }^{90}\right)$. As dimensões dessa enorme massa de metal devem ser comparáveis às pedras imensas que os guerreiros às vezes arremessam em combate. Além da sua incrível letalidade, elas costumam marcar nos poemas o abismo existente entre as capacidades físicas extraordinárias dos homens de outrora, dos heróis, e do homem comum contemporâneo, como, por exemplo, a passagem em Ilíada 12. 445-449. Neste trecho, Heitor ergue uma pedra que, "dois homens, os mais fortes da comunidade não a levantariam/ facilmente com uma alavanca para o alto de uma carroça: homens como os

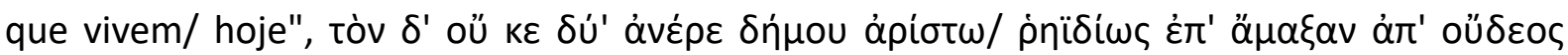

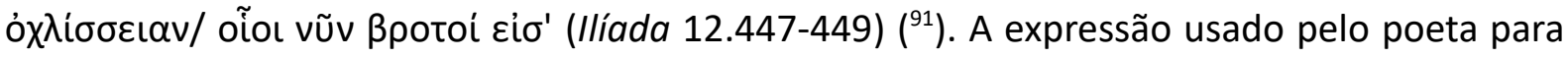

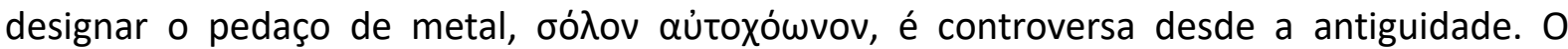

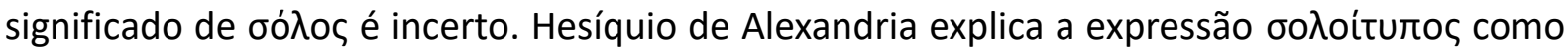

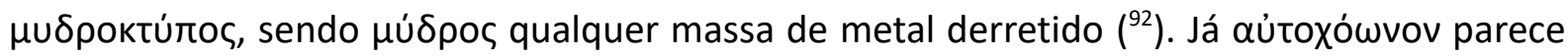
ter o significado de "autofundido", derivado de xóavos. Estudiosos discutem se essa massa de metal seria um meteorito, tal como a Pedra do Bendegó, ou simplesmente a peça fundida saída do forno de fundição. A segunda parece ser mais provável $\left({ }^{93}\right)$. Assim como a lira - bela, bem trabalhada, com armação de prata - e o cavalo, este objeto também tem alto valor.

Polipetes, Leonteu, Ájax Telamônio e Epeio formaram o conjunto de competidores. Polipetes sagrou-se campeão.

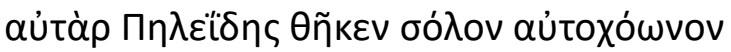

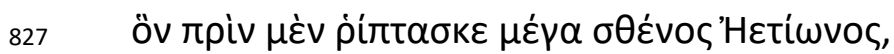

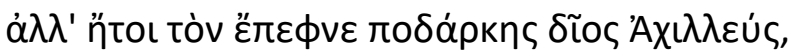

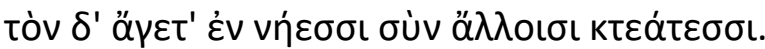

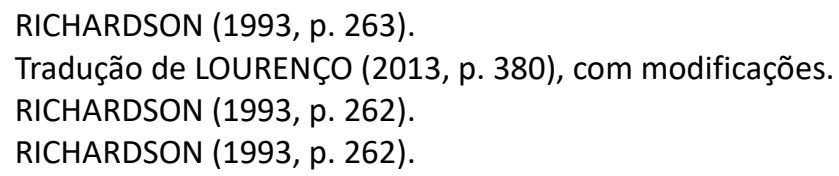


Em seguida colocou o Pelida um pedaço maciço de ferro

Assim como nas outras duas narrativas precedentes, a referência ao objeto dá ensejo a uma oração relativa que o descreve: o instrumento musical, "que arrebatara dos despojos...", tทेv

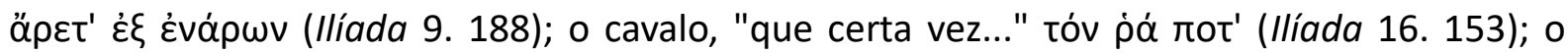
pedaço maciço de ferro, "que outrora...", öv rpiv (llíada 23. 827). A descrição recupera um acontecimento no passado que explica a sua procedência. No caso dos dois objetos prévios, como observamos acima, a sua história é explicita e textualmente relacionada a destruição e saque da cidade de Tebas-sob-Placo: o instrumento musical é arrebatado dos despojos após

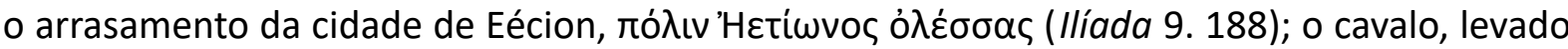

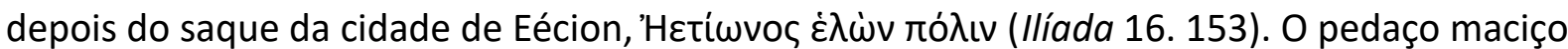
de ferro, no entanto, recebe uma descrição sutilmente diferente. Ele, primeiramente, não é relacionado à atividade da guerra do agente que agora o possui, mas ao uso cotidiano que dele fazia o seu antigo proprietário: "que outrora costumava lançar a grande Força de

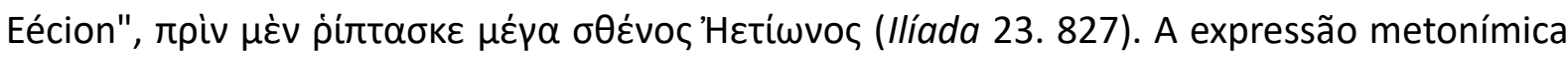

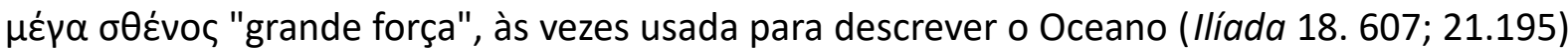

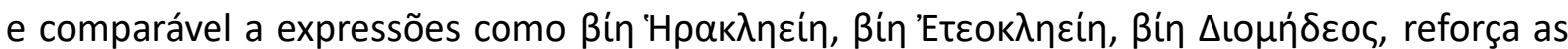
capacidades físicas de Eécion, bem como as características principais do lingote de metal: as suas dimensões extraordinárias e, consequentemente, o seu valor extravagante.

O verso seguinte resume o combate entre Aquiles e Eécion pelo desenlace: "porém,

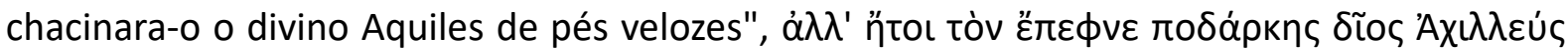
(Ilíada 23. 828). Não há ancoragem lexical, portanto, não há menção direta ao tema do saque e destruição de cidades. Sabemos que a morte de Eécion, governante e campeão tebano, dáse neste contexto graças a detalhes em outras passagens da llíada. Talvez, pela forma como

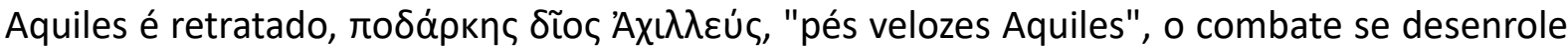
como o enfrentamento entre força física e destreza, tal como o duelo ritual entre Nestor e Ereutálion em Ilíada 7. 124-160. Embora, o excerto troque a destruição da cidade pela morte do seu campeão, o verso seguinte faz referência ao transporte da peça de metal fundida com 
os demais despojos de guerra: "e levara o ferro para as naus com os outros tesouros", tòv $\delta^{\prime}$

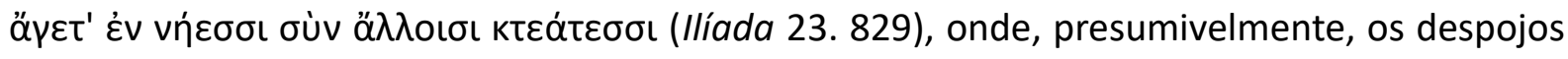
foram divididos entre o exército.

As passagens concernentes ao saque de Tebas-sob-Placo até o momento, podem ser dividas em dois grupos: (1) cujo interesse principal é a ação (2) cujo interesse é o objeto. Da passagem cujo interesse está na ação (Ilíada 1. 366-368), foi possível depreender um roteiro das atividades de guerra: a movimentação do exército, a destruição da cidade, o transporte e a partilha do butim. As do segundo grupo são, naturalmente, mais econômicas na descrição do combate, uma vez que seu interesse principal reside em objetos; mas duas fazem menção à destruição da cidade (Ilíada 9. 188; 16. 153), uma faz menção ao campeão falecido (Ilíada 23. 828) e as outras duas tocam no transporte e partilha dos despojos (Ilíada 9. 188 e 23. 828). Estas passagens, todavia, apresentam a conquista da cidade pelo viés do conquistador. Em um momento oportuno retornaremos outra vez à narrativa de destruição de Tebas-sobPlaco, mas a história será contada desta vez quase da perspectiva de um dos sitiados $\left({ }^{94}\right)$.

\subsection{LIRNESSO E PÉDASO}

Duas outras cidades costumam acompanhar os relatos homéricos acerca de Tebassob-Placo: Lirnesso e Pédaso. Nas passagens em que essas cidades são mencionadas, a sua destruição sempre é atribuída a Aquiles, salvo o trecho em llíada 1. 366, onde encontramos o agente plural. As evidências na llíada e na Cípria, que narrava estes eventos, sugerem que essas cidades teriam sido capturadas e arrasadas em uma mesma expedição $\left({ }^{95}\right)$. O excerto abaixo, retirado de Ilíada 2. 681-694, faz parte do chamado Catálogo das Naus, um incrível tour de force que arrola em cerca de quatrocentos versos os vinte e nove contingentes que formam o exército grego, seus principais líderes, cidades originárias e número de navios $\left({ }^{96}\right)$. O batalhão liderado por Aquiles é primeiramente apresentado com referência ao seu local de origem (llíada 2. 681-683), ao seu gentílico (v. 684) e o número de navios (v. 685), para, em seguida, receber do narrador uma descrição das condições e do estado de espírito em que os

94 Cf. p. 128-137 infra.

95 DUÉ (2011b, 491-492); Idem (2002, pp. 62-63); CURRIE (2015, p. 293).

96 Ver MARKS (2012) sobre a estrutura progamática do catálogo. 
soldados e o seu comandante se encontram:

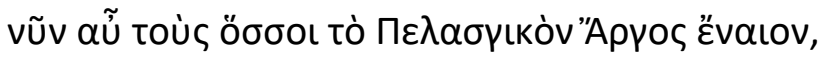

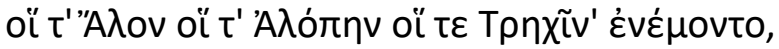

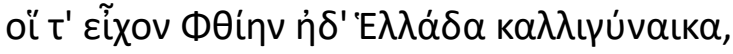

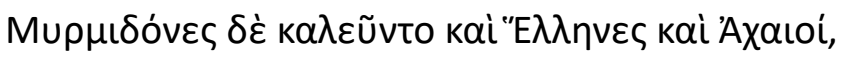

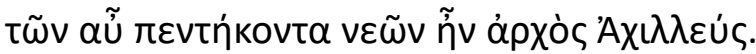

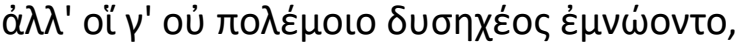

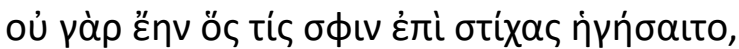

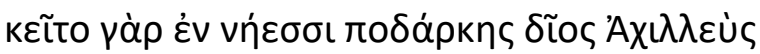

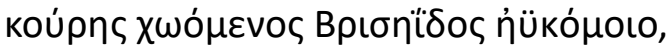

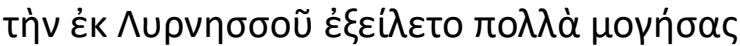

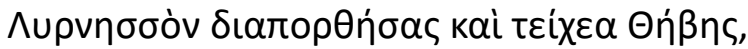

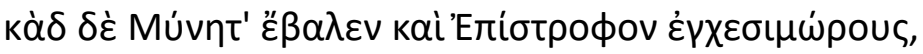

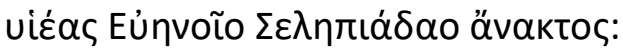

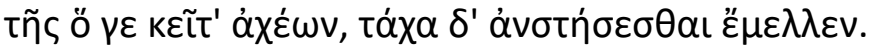

Agora, daqueles que habitavam Argos de Pelasgo, senhores de Alo e Álope, habitantes de Tráquis, que detinham a Ftia e a Hélade, terra de belas mulheres, Mirmidões de seu nome, mas também Helenos e Aqueus: destes comandava Aquiles cinquenta naus. Porém não era na guerra dolorosa que fixavam o pensamento: pois não havia quem os comandasse nas linhas de combate. Junto às naus estava deitado o divino Aquiles de pés velozes, encolerizado por causa de Briseida, donzela de lindo cabelo, que ele trouxera de Lirnesso após grandes esforços, quando destruiu Lirnesso e as muralhas de Tebas, tendo derrubado os lanceiros Mines e Epístrofo, filhos do soberano Eveno, filho de Selepo: por causa dela estava Aquiles deitado em sofrimento. Mas em breve viria o momento de se levantar...

Os Mirmidões não têm a atenção voltada para o combate. Em Ilíada 2. 773-779 a soldadesca passa o tempo entretendo-se com o lançamento de discos e dardos, em competições de tiro

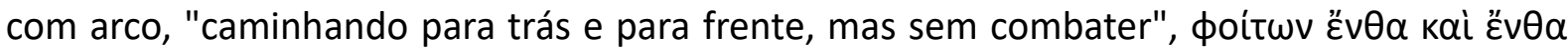

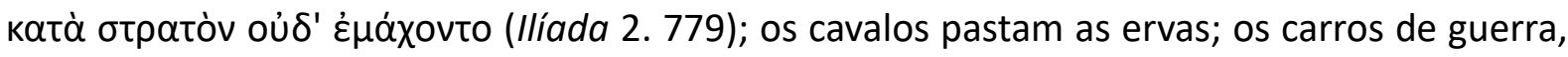
cobertos, ficam guardados nas tendas. $\mathrm{O}$ afastamento do combate é levado ao paroxismo no caso de Aquiles. Ele se acha em completa inatividade, deitado (кعĩto, кعĩt' $\alpha \chi \varepsilon ́ \omega v, 688$ e 694), 
remoendo seus pensamentos. O foco da narrativa se volta para Briseida, cativa de guerra capturada em Lirnesso e a causa do sofrimento do guerreiro, por ter sido levada, contra a sua vontade, por Agamêmnon. Este trecho apresenta uma ordem de organização dos elementos constitutivos do tema da destruição de cidades verificados em outras passagens. Apesar de não haver menção a movimentação ou posição do exército, registramos (1) a destruição da

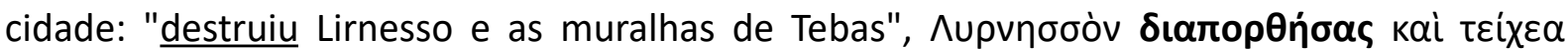

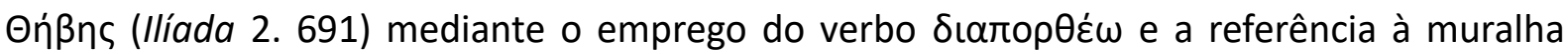
como metonímia para a cidade; (2) a morte dos campeões da cidade: "tendo derrubado os

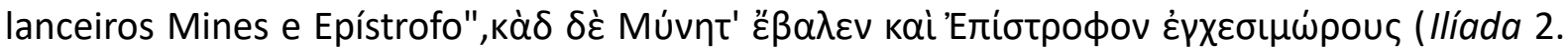
692). Assim como Eécion, Mines também leva destaque como uma figura importante para Lirnesso e para Briseida em Ilíada 19. 296, no lamento para Pátroclo: "saqueou a cidade do

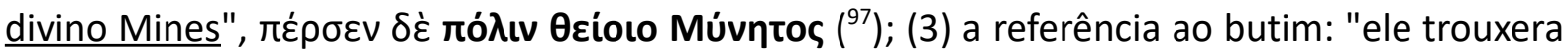

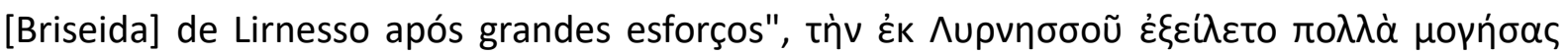

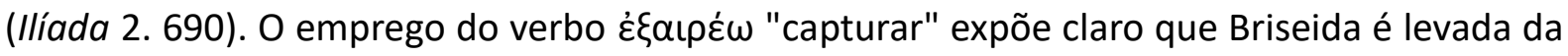
cidade na condição de cativa de guerra. Assim como nas outras passagens, a referência à prisioneira, que deve ser considerada um despojo de guerra, ocasiona uma oração relativa. Esta oração recupera um acontecimento no passado que explica a procedência do despojo, como o lingote de ferro, "que outrora...", öv rpiv (Ilíada 23. 827) e o irrepreensível Pédaso "que Aquiles trouxera depois de saquear a cidade de Eécion" (Ilíada 16. 153). Finalmente, o narrador menciona o esforço dispensado por Aquiles na conquista da cidade: "após grandes

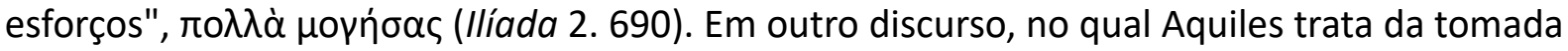
das cidades localizadas nas cercanias da Tróade, também registra-se com bastante ênfase o sofrimento e esforço dos trabalhos de guerra: "nunca tive vantagem alguma por sofrer dores

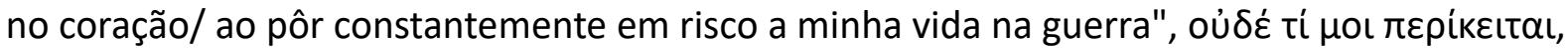

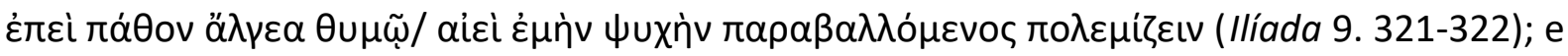
um pouco adiante: "eu mantive vigília durante muiras noites/ e suportei dias sangrentos em

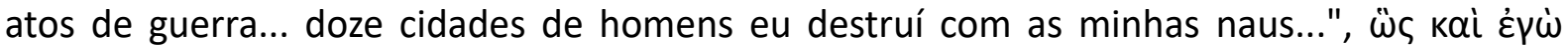

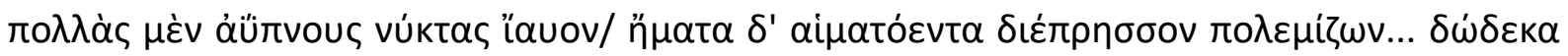

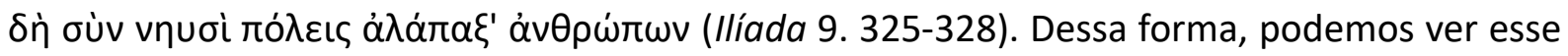

97 DUÉ (2002, p. 60) sugere que Mines pode ter sido esposo de Briseida. 
fenômeno como a outra face de um componente já anteriormente observado: quando um orador deseja valorizar a conquista de uma cidade, ele pode mencionar o número reduzido do efetivo usado no assédio, como Tlepólemo falando sobre Héracles: "só com seis naus e

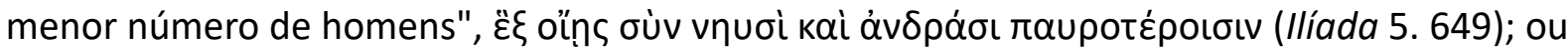
Estênelo e Diomedes: "conquistamos a sede da heptápila Tebas/ quando ambos juntamos

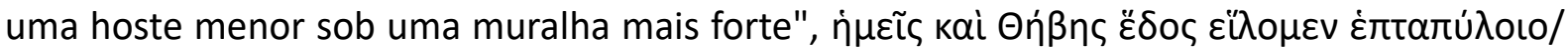

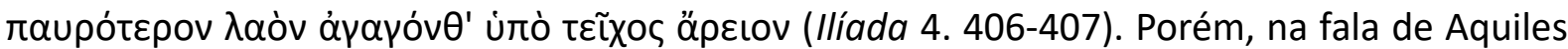
a valorização não se dá mediante a enumeração do número reduzido das tropas, mas antes por meio da ênfase no grande esforço empenhado na façanha.

Estrutura bem diferente pode ser constatada em Ilíada 19. 56-62, trecho do discurso de Aquiles durante o episódio de reconciliação com Agamêmnon na assembleia dos Aqueus. M. W. EDWARDS (1991, p. 241) apresenta a seguinte organização para a primeira parte: (A) esta desavença foi a melhor coisa para nós? (vv. 56-58); (B) era melhor que a garota tivesse perdido a vida, assim os gregos não teriam perecido (vv. 59-62); ( $\left.A^{\prime}\right)$ deste modo Heitor e os troianos levaram a melhor (vv. 63-64). A menção ao saque de Lirnesso se acha na expressão contrafactual de arrependimento:

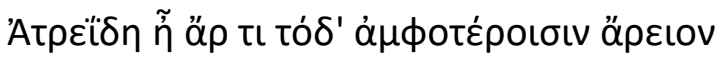

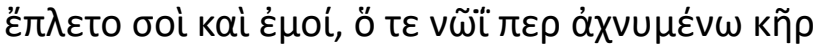

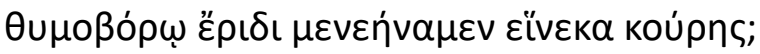

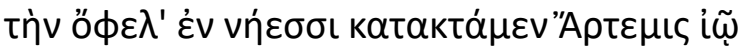

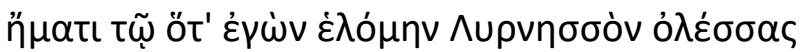
$\tau \omega \dot{~ K ' ~ o u ̉ ~ \tau o ́ \sigma \sigma o l ~ ' A \chi \alpha ı o l ~ o ̉ \delta a ̀ \xi ~ \varepsilon ̌ \lambda o v ~ a ̈ \sigma r \varepsilon t o v ~ o u ̃ \delta \alpha \varsigma ~}$

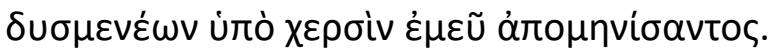

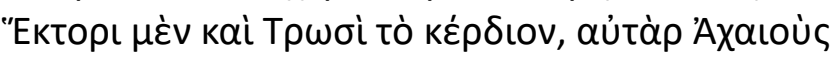

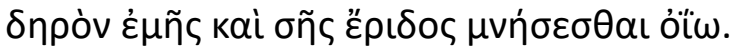

'Atrida será que foi isto a melhor coisa para ambos? para ti e para mim, quando cheios de dor no coração em conflito devorador do ânimo nos zangamos por causa de uma mulher? Quem me dera que nas naus Ártemis a tivesse matado com uma seta, no dia em que a tomei como presa depois de saquear Lirnesso! Não teriam sido tanto os Aqueus a morder com os dentes a ampla terra, sob mãos inimigas, por causa da minha cólera. Para Heitor e para Troia é que isto foi favorável, penso eu que muito tempo se lembrarão os Aqueus do teu e do meu conflito. 
Tal como as outras passagens estudadas, a presente referência encontra-se em uma narrativa embutida (embbeded narrative), porém o que deflagra o relato é um desejo irrealizável:

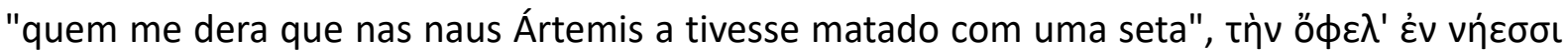

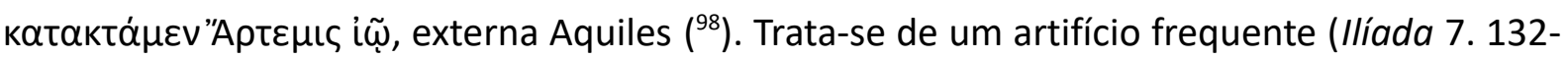
133, Odisseia 4. 341-346, entre outros) e o encontramos em outras narrativas de destruição de cidade $\left({ }^{99}\right)$. Apesar do contexto diferente, o método de exposição dos elementos é semelhante. Depois de minimizar a importância de Briseida, caracterizando-a como apenas

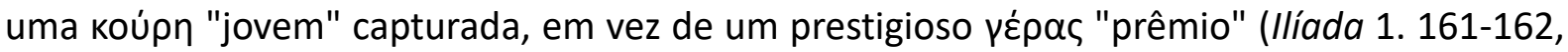

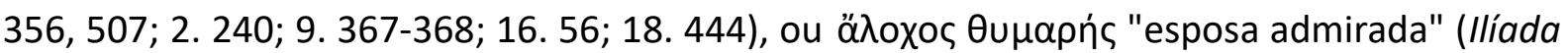
9. 336; 341-343), Aquiles manifesta o seu arrependimento: "quem me dera que nas naus

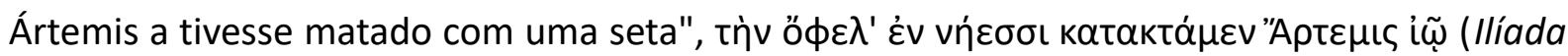
19. 59) $\left({ }^{100}\right)$. A vontade irrealizável se volta para uma ação localizada em um momento específico do tempo, o dia em que a fez prisioneira: "no dia em que a tomei como presa

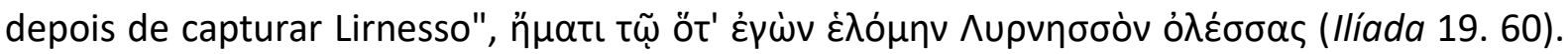
Este verso faz referência à destruição de Lirnesso, pelo emprego do verbo ő $\lambda \lambda u \mu \mathrm{L}$, como também à captura dos despojos de guerra, incluídos entre eles os prisioneiros e as cativas de guerra, como Criseida e Briseida.

Duas outras passagens mencionam a destruição da cidade de Lirnesso por Aquiles. Ambas se encontram em um episódio, incrivelmente longo, de combate singular entre Eneias e Aquiles narrado em llíada 20. 75-352, segmento intrincado que combina batalha campal, intervenções de agentes divinos como Apolo, Hera, Poseidon, muitos discursos, achincalhes, narrativas embutidas, uma árvore genealógica e um pouco de duelo, ainda que sem vítimas. Lirnesso surge, primeiramente, em um conversa entre Apolo disfarçado de Licáon e Eneias (Ilíada 20. 79-102). O deus desafia Eneias a enfrentar Aquiles cara a cara e Eneias recupera, mediante uma analepse, a incursão aqueia envolvendo uma razia de gado e a destruição das cidades de Lirnesso e Pédaso. Esses confrontos, junto com a justificativa de que sempre uma divindade está ao lado de Aquiles, servem para explicar sua relutância em enfrentar o aqueu.

\footnotetext{
98 Ver CHANTRAINE (1958-1963, Vol. II, pp. 261-262).

99 Supra, p. 71.

100 Ver M. W. EDWARDS (1991, p. 241).
} 
Há ainda um outro dado importante mencionado nessas passagens. Eneias, tal qual Aquiles (Ilíada 20. 176-178), estabelece geograficamente a posição das cidades de Lirnesso, Pédaso e consequentemente Tebas-sob-placo, ao situar o evento da razia de gado no monte Ida, presumivelmente na vizinhança de Adramítion (atual Edremit), perto da ilha de Lesbos (LEAF, 1912, pp. 217-221; COOK, 1973, p. 50; DUÉ, 2011b, pp. 491-492). Embora consistam eventos diferentes, essas cidades são destruídas nesta mesma conjunção; Eécion, Epístrofo, Mines e os irmãos de Andrômaca são mortos; Criseida, Briseida e a mãe de Andrômaca são capturadas; o cavalo Pédaso, a lira de prata e a peça de metal fundido, levados para as naus como despojos de guerra. Se levarmos em conta a Cípria (arg. 161-162 Severyns 23-24 West) e a o relato preservado na Epítome de Apolodoro (3.32-33), esta incursão pode ter levado guerra também a Antandro, Lesbos (Ilíada 9. 128-130 e 663-665) e Tênedo (llíada 11. 624627) $\left({ }^{101}\right)$; e possivelmente a Fócia, Cólofon, Esmirna, Clazómena, Cime, Egialo, Adramítion, Teno, Side, Êndion, Líneon, Colone e outras não mencionadas por nome.

Em passagem supracitada da Ilíada, Aquiles se vangloria de ter destruído e saqueado ao todo vinte e três cidades: "doze cidades de homens eu destruí com as minhas naus;/ por

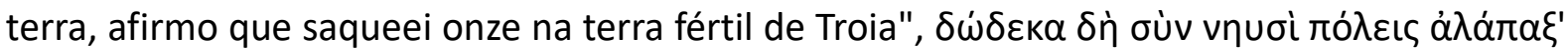

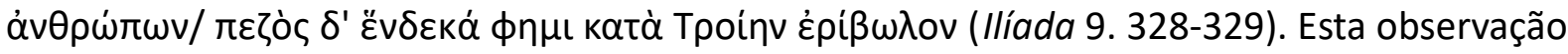
vem no contexto da desavença com Agamêmnon, que ele enxerga como um líder superior na hierarquia, mas inferior em suas capacidades como guerreiro. O foco do discurso de Aquiles repousa sobre a distribuição, na visão dele, injusta dos despojos de guerra, que é reforçado pelo famoso símile da ave que leva comida aos seus filhotes, ao passo que ela própria curte fome. Para VAN WEES (1992, p. 189) essas incursões, realizadas ao lado do objetivo principal da destruição de Troia, tinham como propósito amealhar despojos e víveres para o sustento do exército ao longa da campanha principal. As passagens que narram por meio de analepses esses eventos, por sua ênfase nos despojos de guerra, como temos observado, corroboram essa hipótese.

Quanto a Pédaso, sabemos o nome do seu soberano, Altes, rei dos Léleges: "senhor

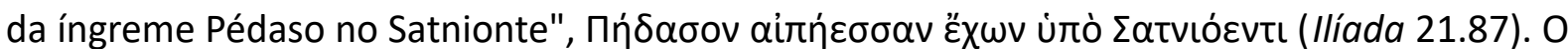
Satnionte é um riacho perto do qual a cidade estava situada: "[Élato] vivia junto às margens

101 Ver DUÉ (2011d, pp. 472-473), sobre as incursões na Troade e a relevância do passado e das narrativas eólicas para a história do desenvolvimento da llíada e da poesia homérica. 


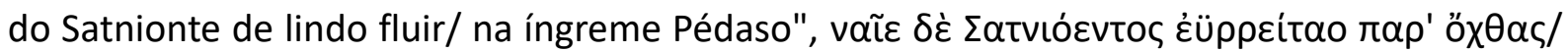

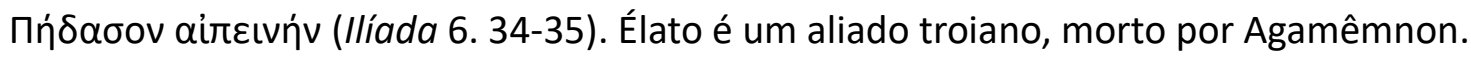

Lirnesso aparece outra vez neste mesmo episódio, agora na boca de Aquiles, em um discurso de desafio $\left({ }^{102}\right)$. Quando Eneias e Aquiles enfim se encontram em campo de batalha, Aquiles é o primeiro a se pronunciar. $O$ discurso do aqueu pode ser grosso modo dividido em duas partes complementares: nos versos 178-186 especula-se os motivos pelos quais Eneias seria levado a se arriscar em combate singular. A possibilidade de Eneias receber das mãos de Príamo a posição de soberano dos troianos é fortemente recusada como não tendo base nenhuma na realidade. Príamo "tem filhos, além de que tem juízo e não está demente", cioiv

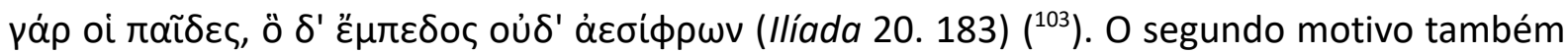
é taxado como impossível: receber terras caso mate Aquiles. Aqui se insere a segunda parte do discurso. Para provar seu ponto, o melhor dos aqueus recupera mediante uma analepse a experiência de enfrentamento entre os dois já mencionada por Eneias a Apolo disfarçado de Licáon um pouco antes: a incursão aqueia envolvendo uma razia de gado e a destruição das cidades de Lirnesso e Pédaso (Ilíada 20. 187-194). Como era de se esperar, Aquiles se ocupa mais demoradamente desse evento do que Eneias, mas Pédaso não é mencionada.

Passemos às duas passagens de Ilíada 20. 79-98 e 176-194:

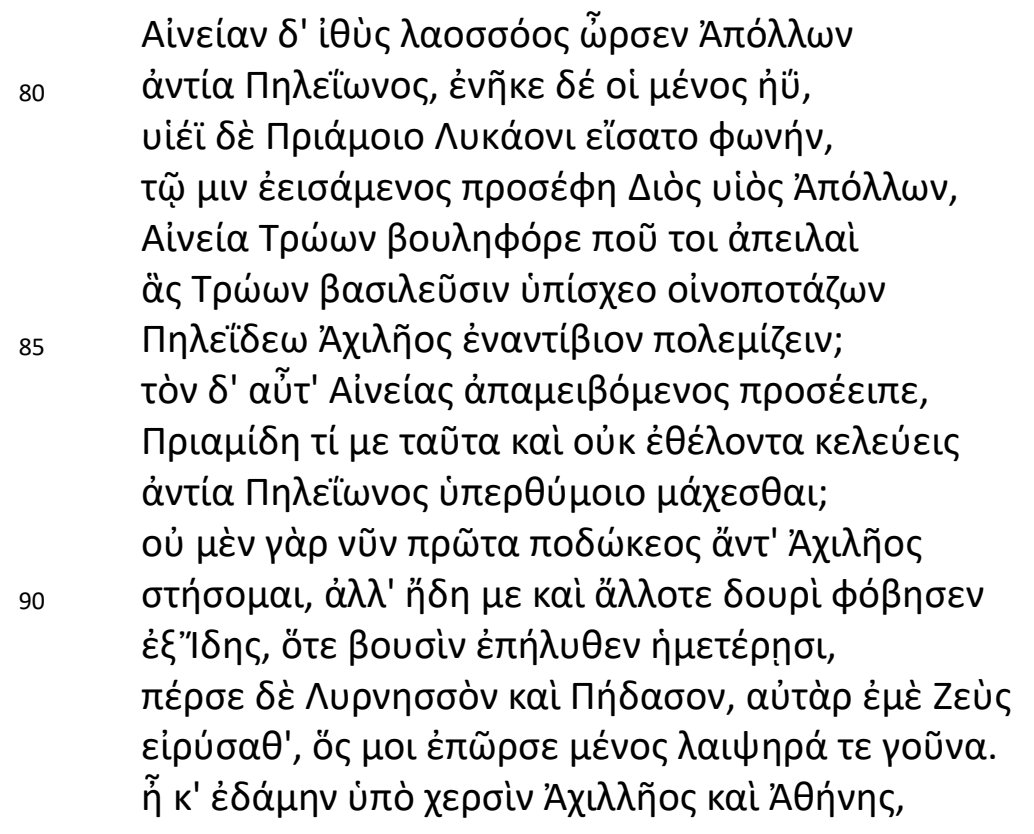

102 Ver EDWARDS (1991, p. 311).

103 Sobre a rivalidade entre as casas reais troianas, M. W. EDWARDS (1991, p. 311); NAGY (1979 pp. 265-275). 


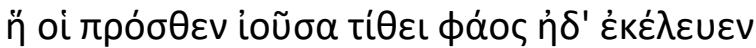

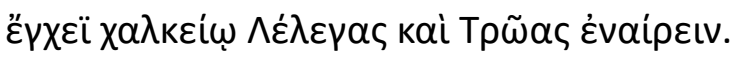

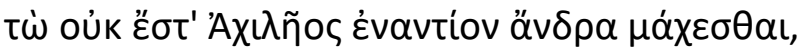

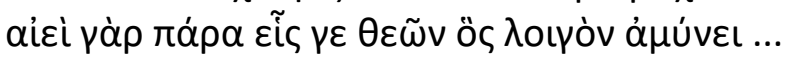

Porém Apolo estimulou Eneias, incitador das hostes, a defrontar o Pelida, e nele insuflou grande força. À voz de Licáon, filho de Príamo, assemelhou a sua voz; e com o aspecto dele assim falou Apolo, filho de Zeu: 'Ó Eneias, conselheiro dos Troianos, onde estão as jactâncias, que bebendo o teu vinho lançavas aos príncipes dos Troianos, de que irias combater frente a frente com Aquiles, o Pelida?'

Respondendo-Ihe assim retorquiu Eneias:

'Priâmida, por que razão me dizes a mim, que não o quero, que combata frente a frente com o presunçoso Pelida?

Não será a primeira vez que defronto Aquiles de pés velozes, mas já antes ele me assarapantou com a lança do Ida, quando investiu contra as nossas manadas, e arrasou Lirnesso e Pédaso. Porém Zeus salvou-me, ele que estimulou a minha força e tornou velozes os meus joelhos. Se assim não fosse teria sido subjugado pelas mãos de Aquiles e Atena, ela que foi a frente dele e lá colocou a sua luz, dizendo-Ihe para matar com a lança de bronze Léleges e Troianos.

Por isso não é possivel a nenhum homem enfrentar Aquiles, pois a seu lado tem sempre ele um deus que afasta a desgraça...

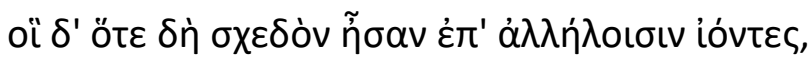

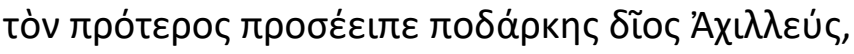

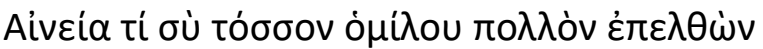

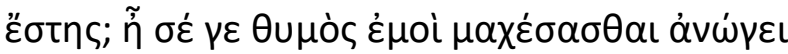

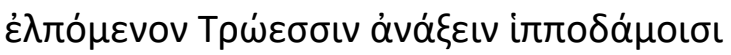

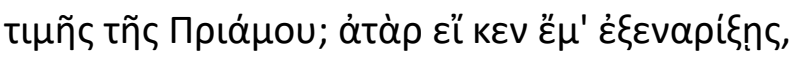

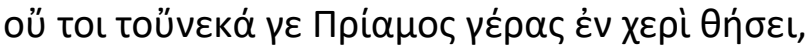

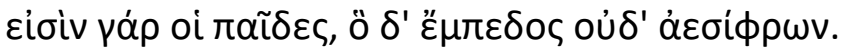

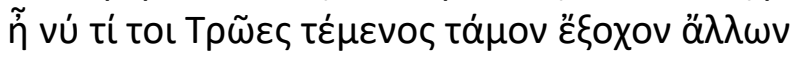

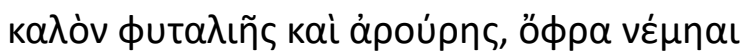

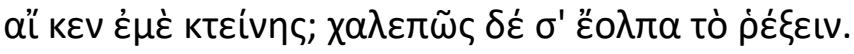

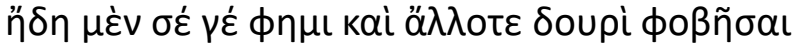

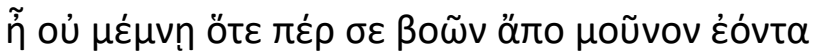

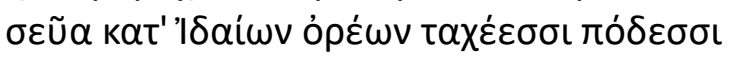

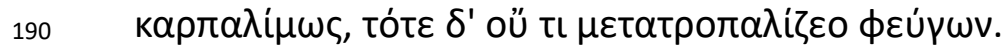

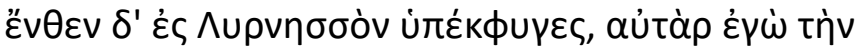

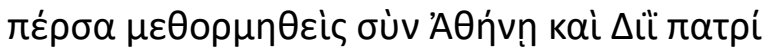




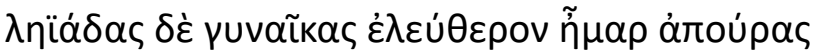

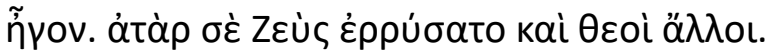

Mas quando já estavam perto, avançando um contra o outro, o primeiro a falar foi o divino Aquiles de pés velozes:

'Eneias, por que razão saíste tão longe da multidão para me enfrentares? Será que o coração te manda combater contra mim, na esperança de entre os Troianos domadores de cavalos da honraria de Príamo te assenhoreares? Porém nem que me matasses, não seria por isso que Príamo te poria tal prêmio nas mãos. Pois ele tem filhos, além de que tem juízo e não está demente. Ou será que os Troianos te demarcaram um domínio senhorial superior aos outros: terra de pomares e lavouras, para nela habitares, no caso de me matares? Porém eu penso que dificilmente o farás. Pois declaro que já outra vez te assustei com a minha lança. Não te lembras da ocasião em que estavas só e te pus a fugir dos bois, a correr com pés velozes das montanhas do Ida a toda a velocidade? Nesse dia fugiste sem olhar para trás. Dali fugiste para Lirnesso, mas eu arrasei a cidade, auxiliado por Atena e por Zeus pai; levei as mulheres como cativas e tirei-lhes o dia da liberdade.

Pela tua parte, foste salvo por Zeus e pelos outros deuses.

Tal como no relato de Andrômaca acerca da destruição de Tebas-sob-Placo, da morte de Eécion, e dos demais membros de sua família em Ilíada 6.413-28, como veremos adiante, há em ambos os trechos supracitados de Ilíada 20.79-98 e 176-194, uma justaposição dos temas do roubo de gado e da captura e destruição de cidades $\left({ }^{104}\right)$. Semelhante justaposição, segundo VIEIRA, "longe de constituir uma característica única dos episódios de razia de gado associados a Aquiles, é uma constante nos outros exemplos iliádicos dessa atividade" (2016, p. 60). Embora não seja possível precisar o encadeamento dos eventos desta incursão aqueia, VIEIRA mostra, a partir do episódio do combate singular entre Aquiles e Eneias em Ilíada 20, que o ataque repentino às reses do inimigo pode ser entendida como uma ação de combate preliminar ao conflito, campal e convencional, e ao arrasamento de uma cidade (2016, p. 60).

A menção ao tema da captura e destruição de cidade encontra-se no seguinte verso:

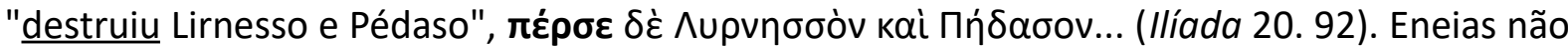
104 Sobre o relato de Andrômaca, ver p. 128-137 infra. 
faz nenhuma referência ao deslocamento do exército dos aqueus. Encontramos apenas uma

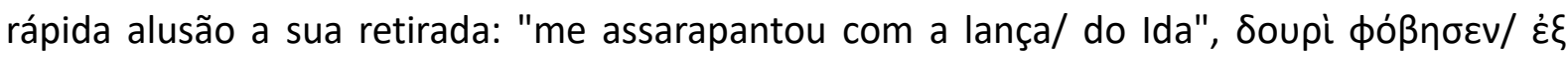

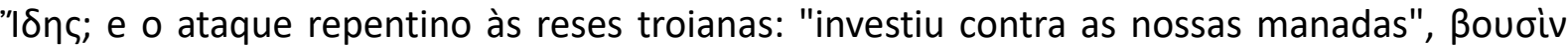

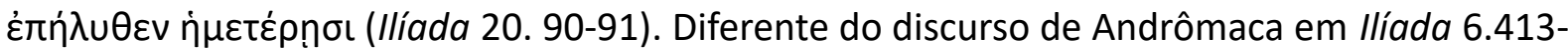
28, que incorpora características do lamento fúnebre, Eneias não faz referência aos caídos em combate, em especial ao campeão da cidade, nem aos despojos levados do local. Por outro lado, encontramos outro elemento, embora neste trecho esteja mais ligado à narrativa da razia do que do saque: a presença dos deuses no combate ao lado do sitiante, "se assim

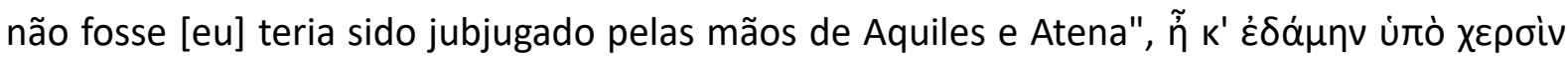

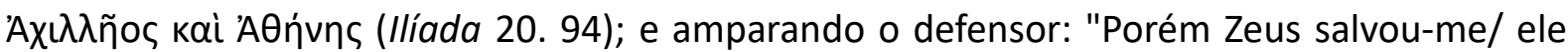

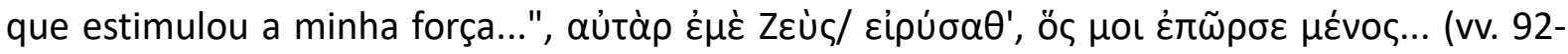
93). A presença das divindades, agora definitivamente relacionada à destruição da cidade, também é ressaltada na narrativa contada por Aquiles: "auxiliado por Atena e por Zeus pai",

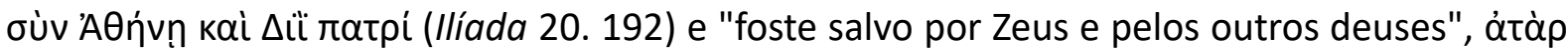

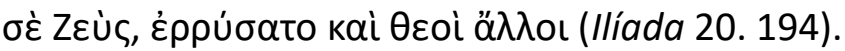

Três dos elementos presentes nos relatos de saque e destruição de cidades resurgem no final do trecho. Lirnesso é apresentada na fala de Aquiles como o local onde Eneias busca refúgio na sequência do ataque contra as reses troianas: "dali fugiste para Lirnesso", ع̋v $\theta \varepsilon v \delta^{\prime}$

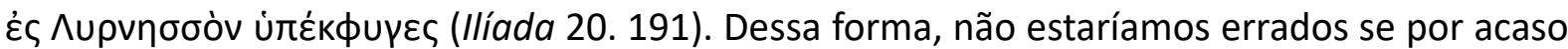
considerássemos a perseguição dos inimigos em fuga como a menção ao deslocamento do exército, também presente em llíada 1. 366. Os versos que descrevem a destruição efetiva da cidade são um tanto exepcionais. Em llíada 20. 191 notamos um hexâmetro terminado em

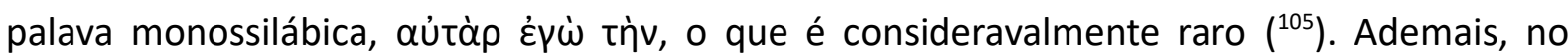

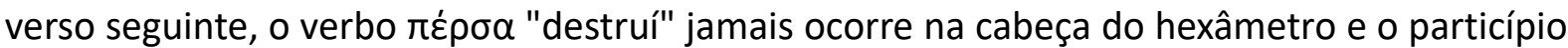
$\mu \varepsilon \theta о \rho \mu \eta \theta \varepsilon i \varsigma$ "tendo perseguido", tem apenas duas ocorrências (Ilíada 20. 192 e Odisseia 5. 325). A conclusão do verso é mais regular. Além da referência aos prisioneiros de guerra,

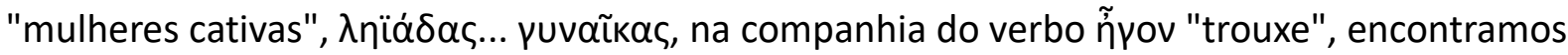

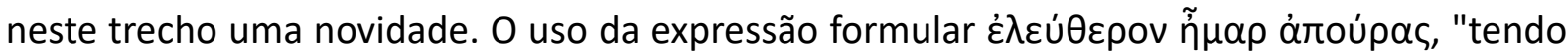
Ihes tirado o dia da liberdade" em Ilíada 20. 193, uma metonímia para a escravização. As 
outras duas vezes em que a mesma expressão é empregada ocorrem dentro deste mesmo contexto, todavia, em prolepses onde se prefigura a destruição da cidade de Troia e a sua consequência para as mulheres que, como descreve a expressão, serão escravizadas (Ilíada 16. 831 e 6.455$)$.

A cidade de Pédaso, mencionada por Eneias neste episódio, jamais é nomeada em qualquer trecho da Ilíada por algum aqueu ou por Aquiles. No entanto pode ter existido uma tradição pré-homérica em que esta cidade recebia maior destaque. Na Cípria, de acordo com um escoliasta, Briseida era levada de Pédaso e não de Lirnesso como afirma a llíada (schol. T ad Ilíada 16.57) ${ }^{\left({ }^{106}\right)}$. Os escólios também preservaram um relato da captura de Lirnesso. 0 texto é atribuído a Hesíodo (schol. bT ad llíada $6.35=214$ Merkelbach-West = 292 Most) $\left({ }^{107}\right)$ ou Demétrio (schol. A ad llíada 6.35) e conta que, durante a guerra de Troia, Aquiles arrasou as cidades nas circunvizinhanças do território troiano até chegar a vez de Pédaso, que antes era chamada de Coloneia. Aquiles desiste de levar o cerco à cidade às últimas consequências

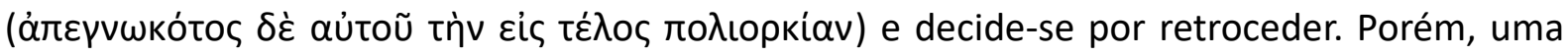
jovem garota vê Aquiles do alto das muralhas e se apaixona por ele. Antes do exército partir, a garota arremessa no meio dos soldados uma maçã com inscrições avisando que a cidade já se encontrava desabastecida de água. Dessa forma, Aquiles e o exército dão prosseguimento ao cerco e capturam aquela cidade $\left({ }^{108}\right)$.

\subsection{LESBOS E ESQUIRO}

Ao lado de Tebas, Lirnesso e Pédaso, Aquiles também captura e arrasa as cidades de Lesbos (Ilíada 9. 128-130, 663-665), Esquiro (Ilíada 9. 666-668) e Tênedo (Ilíada 11. 624-627).

106 Ver DUÉ (2011c, p. 634); idem (2002, pp. 62-63); CURRIE (2015, p. 293).

107 Ver MOST (2007, p. 348, n. 50).

108 É evidente que a beleza, o rapto e a paixão cumpriam um papel importante nas narrativas antigas de saque e destruição de cidades. Além da destruição de Troia, podemos apontar as histórias das cidades de Pédaso e Ecália como exemplos de variações dessa forma de tema ou motivo. O poema Captura de Ecália, sobre uma façanha de Héracles, às vezes atribuído a Homero, às vezes a Creófilo de Samos, pode ter reconstruído o seu enredo da seguinte forma: a ação do poema é desencadeada por uma desavença entre Héracles e Êurito, o soberano da lendária Ecália (Ilíada 2.596, 730; Odisseia 8.224; Hesíodo, Catálogo das Mulheres frag. 26.2833 Most). Héracles é recepcionado na cidade e apaixona-se pela filha de Êurito, Íole. Então, conforme uma das versões, Êurito se compromete a dá-la em casamento, porém, logo muda de ideia e recusa-se a fazê-lo. Em outra versão, Héracles decide raptar a garota. Seja qual for a versão encontrada na Captura de Ecália, o desentendimento com Êurito e a paixão por Íole acarretam a captura e destruição da cidade. 
As três localidades são mencionadas em três extratos que introduzem o tema da destruição por meio de brevíssimas narrativas embutidas, as quais tem por gatilho mulheres capturadas como cativas de guerra. As de Ilíada 9. 128-130 são mencionadas por Agamêmnon dentro do contexto da embaixada enviada à tenda de Aquiles para tentar convencê-lo a retornar ao combate. O comandante dos aqueus considera um erro ter tomado Briseida e prepara uma compridíssima e irresistível lista de presentes, alguns para serem concedidos imediatamente, outros por ocasião do saque da cidade dos troianos, outros ainda quando do retorno para casa (Ilíada 9. 121-130). Nas listas de presentes apresentada por HAINSWORTH (1993, p. 74), mulheres não estão sempre presentes. Em Ilíada 24. 229-234: roupa, ouro, trípode, taça; em Odisseia 4. 128-135: banheira, ouro, trípode, roca, cesto; Odisseia 8. 392-393: roupa e ouro; Odisseia 9. 202-205: ouro, taça, vinho; Hesíodo frag. 154e Most = 200 Melkerbach-West: vaso, trípode, ouro. Mas aparecem em Odisseia 24. 274-277: ouro, taça, roupa e mulheres; Em llíada 8. 290-291, ao lado de trípodes, cavalos e carro de guerra, Agamêmnon promete a Teucro que, quando do saque de Troia, dará a ele uma mulher de presente: "uma mulher que

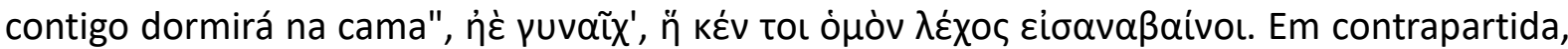
em Hesíodo frag. 154b = 197 Melkerbach-West os pretendentes de Helena trazem mulheres, que por sua vez carregam em suas mãos jarras de ouro como presentes. Por óbvio, não há conotação venérea ou de abuso, como em Ilíada 8. 290-291. Pelo contrário, as mulheres são

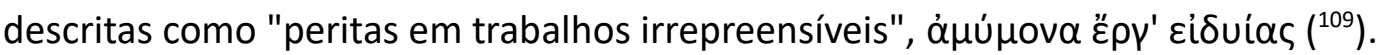

A expressão "mulheres peritas em trabalhos irrepreensíveis", үuvaĩkaৎ $\alpha \mu u ́ \mu o v \alpha ~ \varepsilon ̋ \rho \gamma^{\prime}$

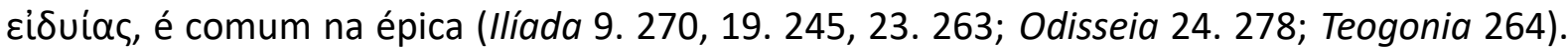
Esta expressão também é usada para descrever as mulheres que aparecem arroladas na lista de presentes de Agamêmnon em Ilíada 9. 128-130. Ela enfatiza a habilidade dessas mulheres

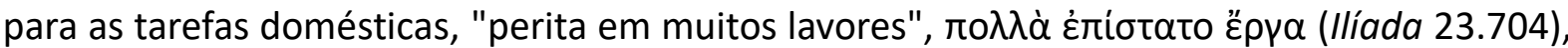
principalmente a tecelagem $\left({ }^{110}\right)$. Todavia, ao mesmo tempo, em outras passagens a beleza dessas mulheres pode ser ressaltada, dando outras conotações como, por exemplo, Odisseia 24. 279-280, em que são dadas como presente "quatro formosas mulheres, que ele próprio

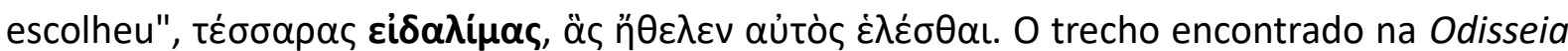

\footnotetext{
109 As cativas de guerra também são oferecidas como prêmios nas jogos fúnebres em honra de Pátroclo, ver llíada 23.2261-263.

110 GRIFFIN (1995, p. 91).
} 
é comparável no tom à passagem em que Agamêmnon enumera os seus presentes, uma vez que as sete cativas de guerra oferecidas pelo comandante dos aqueus são nativas da ilha de Lesbos, onde as mulheres eram famosas por sua beleza e onde concursos de beleza eram organizados, como se pode depreender do fragmento 130 b de Alceu $\left.{ }^{111}\right)$. Inclusive, há uma teoria segundo a qual Briseida poderia originalmente ser de Lesbos. Como notamos, a Ilíada coloca a cativa em Lirnesso, a Cípria e outras tradições pré-homéricas, em Pédaso, mas a

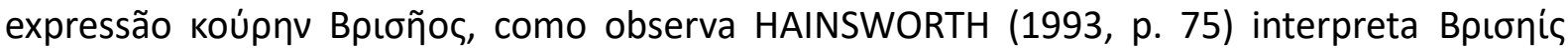
como um patronímico análogo a Xpuoniç. Isso poderia fazer de Briseida uma nativa de Brisa, uma cidade ou povoado localizado em Lesbos $\left({ }^{112}\right)$.

Eis a passagem em questão; llíada 9. 128-130:

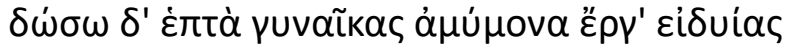

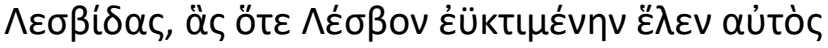

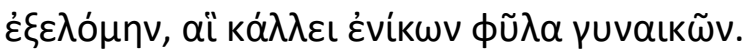

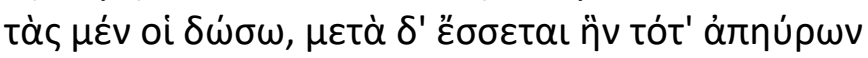

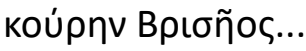

Darei ainda sete mulheres peritas em trabalhos irrepreensíveis mulheres de Lesbos; quando ele tomou Lesbos bem construída eu escolhi-as; elas que pela beleza vencem todas as raças das mulheres. Serão estas que lhe darei e entre elas estará a que Ihe tirei, a filha de Briseu...

Agamêmnon promete presentear Aquiles com sete cativas peritas em tarefas domésticas. As mulheres servem de gatilho para se recuperar um evento do passado recente, por meio de

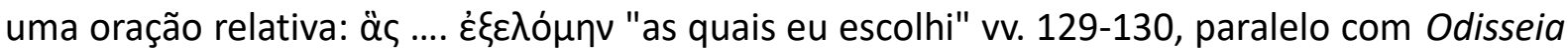

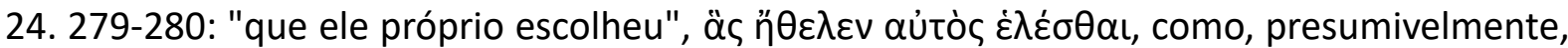
em um concurso de beleza. Esta suposição pode ser corroborada pelo verso que caracteriza as mulheres de Lesbos: "elas que pela beleza vencem todas as raças de mulheres", aï ká $\lambda \lambda \varepsilon \iota$

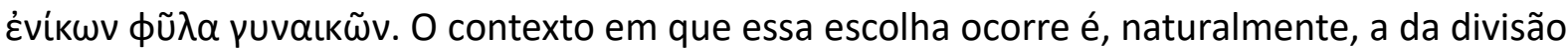
dos despojos de guerra, após a tomada da ilha: "quando ele tomou Lesbos bem construída",

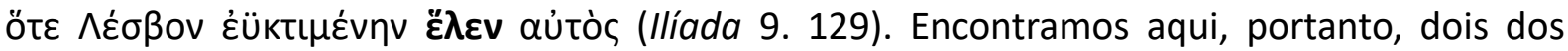


elementos atinentes ao tema do saque e destruição de cidades. As mulheres cativas são elas mesmas o terceiro elemento.

Encontramos panorama semelhante na conclusão de llíada 9. A noite vem chegando e os guerreiros retiram-se para dormir. Aquiles deita-se ao lado de uma cativa, capturada em

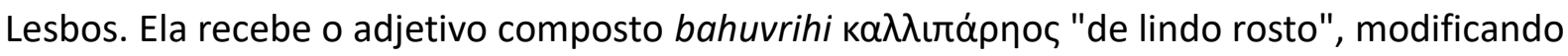
5x Briseida (Ilíada 1. 184, 1. 323, 1. 346, 19. 246, 24. 676), 3x Criseida (Ilíada 1. 143, 1. 310, 1. 369), 3x Teano (Ilíada 6. 298, 6. 302, 11. 224), 1x Têmis (Ilíada 15. 87), 1x Leto (Ilíada 24. 607), 1x Helena (Odisseia 15. 123), 1x Melanto (Odisseia 18. 321). Isso aparenta reforçar a concepção de que a beleza é um traço típico das nativas de Lesbos, ao menos imaginário do poema, além de uma característica visada durante a escolha ou divisão das cativas de guerra em Homero.

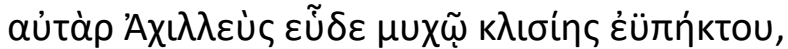

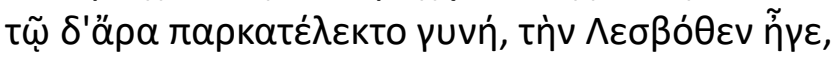 \\ 665

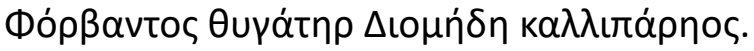

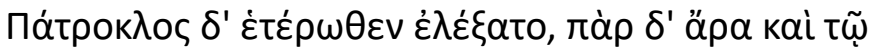

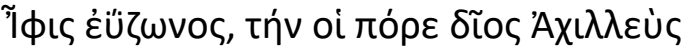

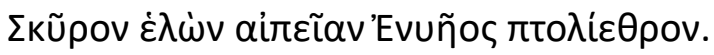 \\ Mas Aquiles foi deitar-se no recesso interior da tenda bem construída; \\ ao seu lado dormiu uma mulher, que ele trouxera de Lesbos, \\ 665 filha de Forbante, Diomeda de lindo rosto. \\ E Pátroclo deitou-se do lado oposto: junto dele dormia \\ Ífis de bela cintura, que Ihe dera o divino Aquiles \\ quando tomou a íngrime Esquiro, cidade de Enieu.
}

Embora não seja possível afirmar com certeza, estas características reconhecidas nas cativas da ilha de Lesbos devem também se repetir para a cativa Ífis que, nesta mesma cena, dorme

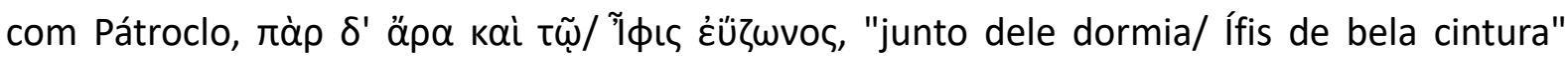

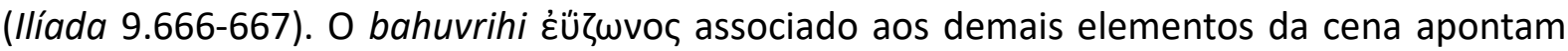
também nessa mesma direção $\left({ }^{113}\right)$.

Como temos observado nas passagens, despojos e cativas de guerra podem ocasionar

113 HAINSWORTH (1993, p. 146) vê degradação na situação das mulheres. O comentador acredita que o fato das mulheres serem nomeadas e terem seus parentesco mencionado sugere que essas cativas podem ter feito parte da aristocracia em suas comunidades e acabaram reduzidas à servidão. 
narrativas embutidas de tomada de cidade. Observamos o mesmo fenômeno em relação à cativa que dorme com Pátroclo. Ela foi escolhida por Aquiles, teoricamente, durante a divisão

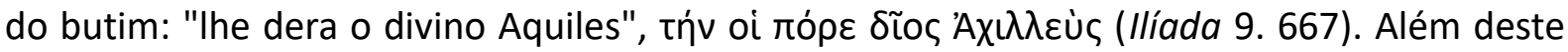
elemento, reconhecemos ainda outros dois em um único verso, a referência à destruição da cidade, sinalizada pelo verbo aipéw, e ao seu campeão ou soberano: "quando tomou a

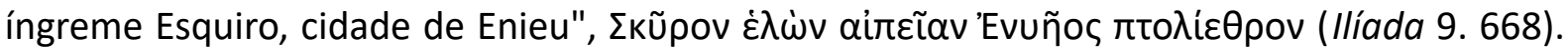
Esta conquista, segundo a Cípria, teria acontecido depois da chamada "expedição teutrânia" (arg. 125-128 Severyns, Apolodoro Epítome 3.17-18, schol. D ad llíada 1.59), uma campanha militar cuja estrutura narrativa é modelada com base na Guerra de Troia, como doublet $\left({ }^{114}\right)$. Após uma tempestade no mar, "Aquiles, que aporta em Esquiro, esposa a filha de Licomedes, Didamia" (Cípria arg. 130-131 Severyns) ${ }^{115}$ ). Ilíada 19. 326 (schol. T) e Odisseia 11. 506-509, parecem conhecer essa história nas menções a Neoptólemo, filho de Didamia e Aquiles. A Pequena llíada (frag. 4 West $=4$ Davies $=24$ PEG) também menciona a cidade, mas apenas a Ilíada (9.668) faz referência a captura e destruição desta cidade $\left({ }^{116}\right)$.

\section{$3.4 T E \hat{E} N E D O$}

Assim como Esquiro, Tênedo está relacionada a uma série de narrativas tradicionais, de tradição pré-homérica e homérica. Nos poemas da llíada e Odisseia, além de esta cidade ser nomeada regularmente (Ilíada 1. 38, 1. 452, 11. 625, 13 .33,; Odisseia 3. 159), Tênedo se encontra ligada a um par de narrativas analépticas de saque e destruição de cidades (Ilíada 11. 624-627) e uma variação sobre o tema do vóotos "retorno" (Odisseia 3. 153-169). Nas tradições pré-homéricas registradas nos poemas cíclicos, a Cípria menciona a ilha de Tênedo, onde Filoctetes recebe a mordida da serpente e, por causa do mau-cheiro do ferimento, é abandonado pelo exército dos Aqueus (arg. 145 Severyns 9b West). Tênedo também é citada em uma narrativa de desavença entre Aquiles e Agamêmnon (arg. 146-147 Severyns 9c West 21 West) $\left({ }^{117}\right)$. Além disso, a ilha serve de esconderijo aos aqueus durante a execução do estratagema do cavalo de madeira (Pequena llíada arg. 230-232 Severyns; Saque de ìlion arg.

\footnotetext{
114 Ver CURRIE (2015, p. 290); idem (2016, pp. 239-246); BURGESS (2011a, p. 808).

115 Tradução de GATTI (2012, p. 136), WEST (2013, pp. 107-109) para mais detalhes.

116 Ver CURRIE (2015, p. 290, n. 80); KELLY (2015, p. 340), BURGESS (2001, p. 24).

117 Ver BURGESS (2011b, p. 847) e WEST (2013, pp. 111-113) para mais detalhes.
} 
254-256 Severyns) e na tradição posterior é palco do duelo entre Aquiles e Tenes (Apolodoro, Epítome 3.23-26). Ainda que Tênedo possua uma rica tradição épica, somente uma passagem da llíada faz alusão a sua destruição, alusão esta que também faz parte do contexto geral de uma analepse que explica a procedência de uma cativa de guerra. Neste passo da narrativa, Pátroclo procura por Nestor para obter maiores informações sobre o crescente número de guerreiros aqueus feridos. Nestor o recebe, de acordo com as regras de hospitalidade, e uma mulher cativa prepara para os dois uma bebida, Ilíada 11. 624-62:

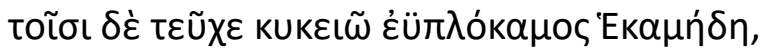

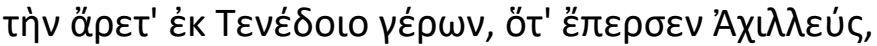

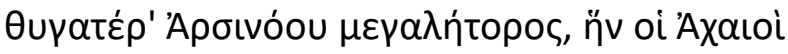

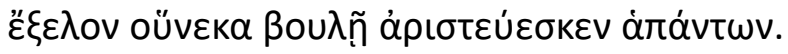

E para eles misturou a bebida Hecameda de belas tranças ela que o ancião trouxera de Tênedo, quando Aquiles saqueou a cidade, filha do magnânimo Arsínoo, tinham-na escolhido os Aqueus para ele, porque de todos ele era o melhor no conselho.

A menção à cativa serve de gatilho para a narrativa embutida de destruição de cidades. As

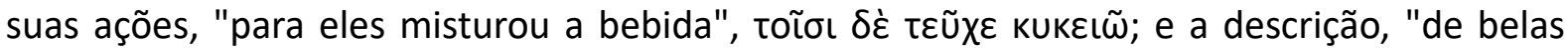

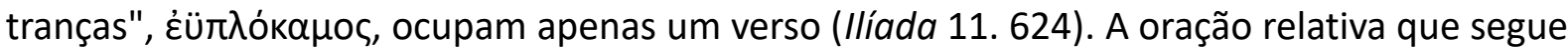
por primeiro descreve sua condição de cativa: "ela que o ancião trouxera de Tênedo", tท̀v

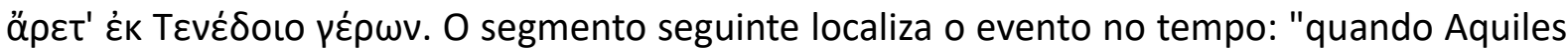

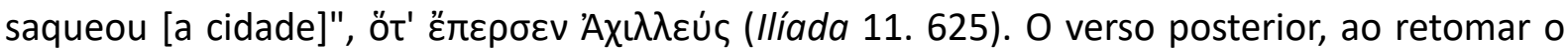
seu parentesco imediato, parece recomeçar o processo de descrição da cativa. Hecameda é filha de Arsínoo. Segundo HAINSWORTH (1993, pp. 291-292), o nome "Arsínoo" talvez tenha conexões com Messina no Peloponeso. Isso estabeleceria para essa personagem relações um pouco distantes demais de Tênedo. Segundo os padrões que temos observado nas descrições dos despojos, das mulheres cativas de guerra e no lamento fúnebre, pode-se cogitar outras função para o surgimento do nome de Arsínoo neste contexto, como, por exemplo, a de um campeão ou soberano morto durante a defesa da cidade, tal Mines em Ilíada 2. 692, 19. 296; ou Eécion em llíada 6. 405-434. Impossível, todavia, comprovar. Seja qual for a verdade, este 
dado novo de informação, que recomeça a descrição da cativa, começa outra oração relativa que descreve a partilha pelo exército dos despojos recolhidos da cidade e o motivo para tê-lo recebido (Ilíada 11. 626-627).

Assim, embora aparentem estar organizados em uma ordem singular, os elementos presentes na narrativa embutida sobre a tomada e destruição de Tênedo correspondem aos elementos encontrados nas demais passagens relacionadas a este tema, particularmente aos elementos em llíada 9. 663-668 descritos. A breve descrição da cativa, a referência à ocasião de sua captura na conquista de uma ilha, o transporte dos despojos de guerra, a divisão dos butim pelo exército, a escolha e a motivação por detrás da escolha da cativa. Estas unidades constituem um padrão ainda que maleável e formam um conjunto de referências regulares para o tema da captura e destruição de cidades. 


\section{AS VÍTIMAS}

\subsection{TROIA 2.0}

O episódio em que é narrado o estratagema do cavalo de madeira, artifício pelo qual Odisseu captura a cidade de Troia e a arrasa, é incrivelmente complexo, como a maioria das narrativas encontradas na Odisseia. Sua estrutura começa em Odisseia 7. 189-196, quando o rei Alcínoo declara publicamente para os feácios que reunirá em seu palácio o maior número de anciãos possível para entreter Odisseu em um banquete e posteriormente transportá-lo para Ítaca: "[receberemos] o estrangeiro aqui no palácio e [sacrificaremos]/ aos deuses belas

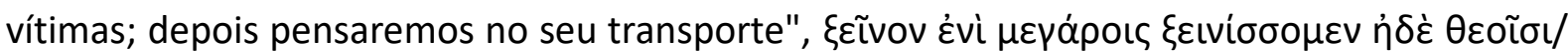

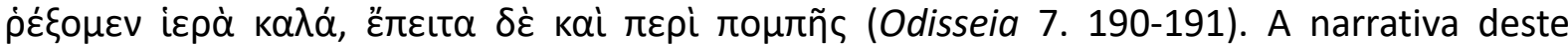
banquete que vai reunir quase toda a aristocracia feácia se prolonga até Odisseia 13.17, é o dia mais longo de todo o poema, o trigésimo terceiro dia $\left({ }^{118}\right)$. A estrutura do episódio, como constata DE JONG (2001, p. 190), apresenta a declaração de Alcínoo de trás para adiante: (1) primeiramente, Alcínoo anuncia publicamente, em uma assembleia, que Odisseu será levado para casa (Odisseia 8. 1-47); em seguida, (2) os marinheiros feácios preparam o barco para o transporte (Odisseia 8. 48-55). A partir deste ponto inicia-se verdadeiramente a recepção e o entretenimento, que aparece subdividido em três cenas de (3) banquete e canção(Odisseia 8 .63-103); (4) competições atléticas e canção (Odisseia 8. 104-468); e (5) banquete e canção (Odisseia 8. 469-586).

Desde o terceiro verso de Odisseia 8, o narrador prepara sua audiência para a canção de Demódoco na quinta parte do episódio, a canção que narra a tomada de Troia. O narrador por meio da ferramenta narrativa da semente $($ seed $)\left({ }^{119}\right)$ usa o famoso epíteto $\pi$ to $\lambda$ íropӨos "eversor de cidades". A interpretação tradicional defende que, sobretudo na ilha dos feácios, Odisseu passa por um processo de recuperação da sua identidade heroica após tantos anos fora de ação em Ogígia ao lado de Calipso. O herói chega à ilha na condição de náufrago ou andarilho, ele se esconde entre as raízes de uma oliveira e cobre-se com folhas. O narrador o 
compara à brasa que um homem esconde entre as cinzas, "salvaguardando desse modo/ a

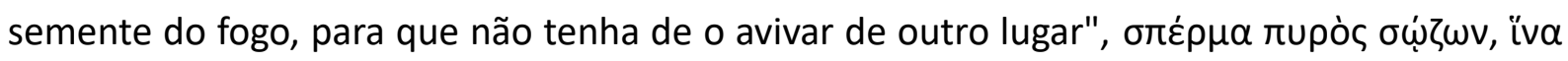

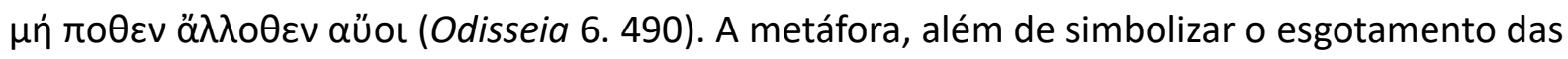
forças de Odisseu, aponta para sua identidade heroica latente. Ao longo deste episódio ele escutará canções que destacam as virtudes heroicas odisseicas, disputará os jogos atléticos e medirá forças com os jovens feácios, receberá um "embelezamento", presentes e, depois de contar ele mesmo as suas aventuras nos Apologoi, deixará a ilha totalmente restaurado.

Além dos jogos atléticos, as canções são particularmente importantes. Elas envolvem um episódio do começo da guerra, a saber, a desavença entre Aquiles e Odisseu; e envolvem um episódio da conclusão da guerra: o estratagema do cavalo de madeira e a destruição da cidade troiana. Entre as duas, o aedo canta um prelúdio sobre o amor entre Ares e Afrodite, que também está relacionado ao eixo temático das outras duas canções e do poema: o tema

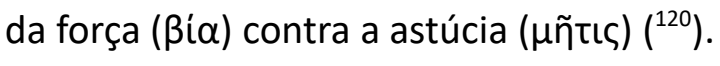

A primeira canção de Demódoco, tal como as outras duas, é narrada indiretamente. Trata-se da narrativa da narrativa, de modo que os detalhes dessa história são amplamente deixados para a imaginação. O seu tema é um evento ainda do início da guerra, a "desavença

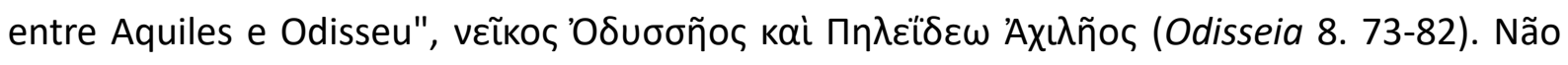
há menção a esta desavença no resto dos poemas homéricos, entretanto, talvez o poema da Cípria narrasse esse evento, que teria acontecido em Tênedo (Cípria frag. 21 West e arg. 146147 Severyns). Agamêmnon se apraz com a cizânia entre "os melhores dos aqueus", äpıotoı A $\chi \alpha \iota \tilde{\omega} v$ (Odisseia 8. 78) pois que Apolo, por meio de um oráculo, havia profetizado que Troia seria capturada após semelhante evento. Dessa forma, o ponto principal da canção envolve o tema dos "melhores dos aqueus", estudado por NAGY (1979) e constante na Ilíada. O poema ora opõe Aquiles (qualidades internas) e Agamêmnon (qualidades externas) $\left({ }^{121}\right)$, ora Aquiles e Ájax, Aquiles e Diomedes, ora Aquiles e Odisseu e Idomeneu. A Odisseia, por sua vez, opõe Aquiles como símbolo da força bruta ( $\beta \dot{i} \alpha)$, do ataque frontal na batalha ( $\pi$ ó $\lambda \varepsilon \mu \circ \varsigma$ ) a Odisseu

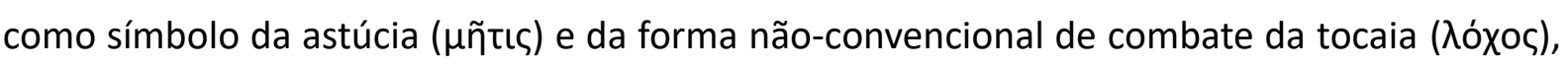

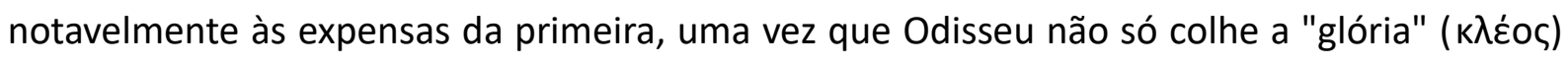

120 DE JONG (2001, p. 196); GARVIE (1994, p. 250); NAGY (1979, pp. 22-25).

121 M. W. EDWARDS (1988, pp. 173-174 e 178-182) 
da captura e destruição de Troia, como também logra o "retorno" (vóotoc) para casa ${ }^{122}$ ).

Este mesmo eixo temático também é colocado em cena na segunda canção do aedo Demódoco, "o amor entre Ares e Afrodite" á $\mu \phi$ ' 'A (Odisseia 8. 266-369). Essa história tem sentidos diferentes para os personagens, assim como para o público $\left({ }^{123}\right)$. Ela toca no tema do adultério de Afrodite e estabelece uma comparação, principalmente pelo uso do adjetivo distintivo "cadela" (кuvẃrıৎ 8. 319), com Clitemnestra, Helena e, potencialmente, Penélope. Nas justaposições homéricas, desavenças entre deuses são resolvidas rapidamente entre risadas, enquanto as humanas têm implicações dramáticas, como a reconhecida justaposição do desentendimento em llíada 1. 53-305 com a assembleia divina em Ilíada 1. 493-611. Enquanto no embate entre Ares e Hefesto o problema se resolve com a aplicação de uma multa, Egisto e Clitemnestra, a população troiana e os pretendentes de Penélope pagam com suas vidas.

Mais importante para os nossos presentes propósitos é o enfrentamento entre Ares e Hefesto. No intuito de surpreender a esposa, Afrodite, e o amante, Ares, o deus coxo prepara uma emboscada. Após fabricar um conjunto de redes "[impossível] de quebrar e deslaçar"

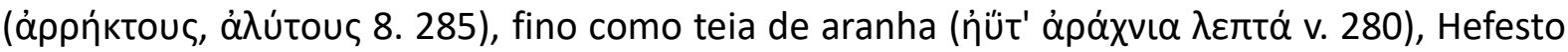

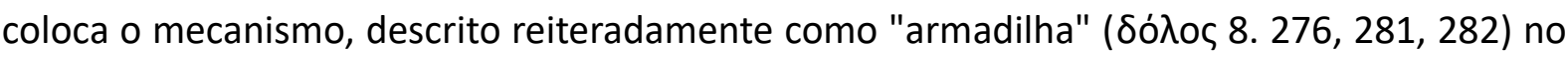

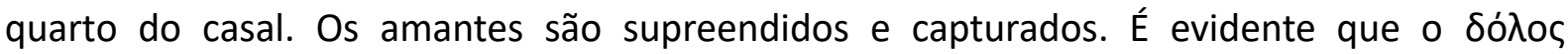
"armadilha", "estratagema", "mecanismo", é uma manifestação das capacidades intelectuais de Hefesto e, portanto, de sua "astúcia" ( $\mu$ ñtıৎ). Esta narrativa coloca em cena pela segunda

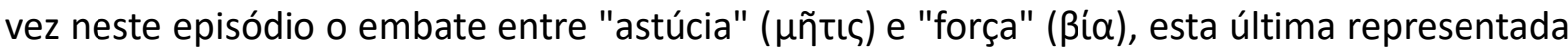
por Ares, o deus da chacina em combate. A canção encena ainda outras oposições como as

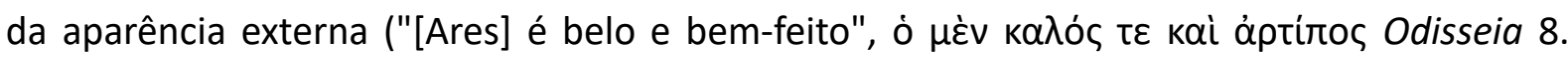
310) versus qualidades internas; o coxo e lento Hefesto ("eu nasci/ estropiado" nं

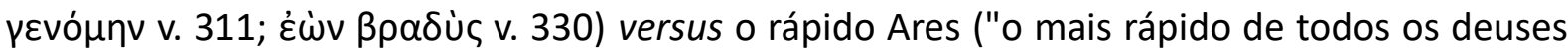

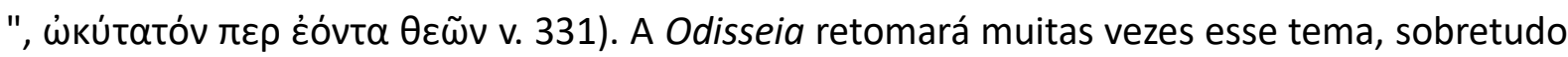
nos embates entre Odisseu e Polifemo, na emboscada e chacina dos pretendentes perto do desfecho do poema e na próxima canção de Demódoco.

A quinta e última parte deste episódio abre com uma cena de banquete equivalente à

122 Ver A. T. EDWARDS (1985, pp. 18-19), DUÉ \& EBBOTT (2010, pp. 34-43 e 69-79).

123 DE JONG (2001, p. 206). 
primeira (Odisseia 8. 63-103), porém desta segunda vez a estrutura encontra-se desenvolvida mais longamente para reforçar a importância da cena $\left({ }^{124}\right)$, afinal, é na conclusão desta cena que Alcínoo finalmente questiona a identidade até ali desconhecida do estrangeiro. Odisseu entra no salão quando a comida está sendo servida e profere um discurso cujo objetivo é fazer com que o aedo receba a porção de honra (vw̃̃ov) (8. 477-481). Odisseu começa seu segundo discurso com um elogio a Demódoco: "É com grande propósito que cantas o destino dos Aqueus", $\lambda i ́ n v$ yà Odisseu é de que o aedo foi testemunha ocular dos eventos narrados na primeira canção. Ele passa então do elogio ao pedido: "Mas muda agora de tema e canta-nos a formosura do

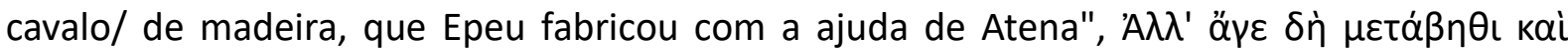

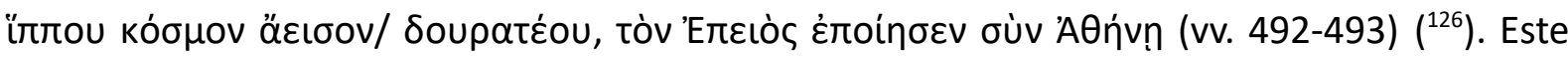
episódio é uma das maiores provas, senão a maior de todas, da excelência guerreira de Odisseu, uma vez que a ele é atribuído o saque e destruição de Troia ("...os homens que

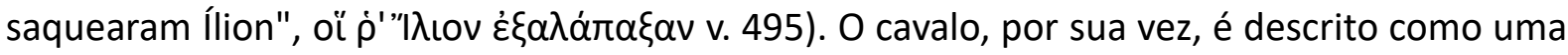

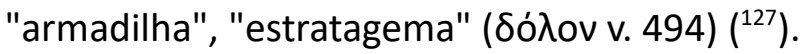

O "estratagema" de Odisseu, como manifestação da sua "astúcia", deve ser entendido como uma emboscada (DUÉ \& EBBOTT, 2010, p. 74). O cavalo de madeira é categoricamente

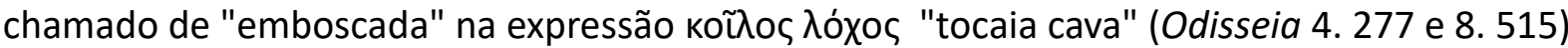

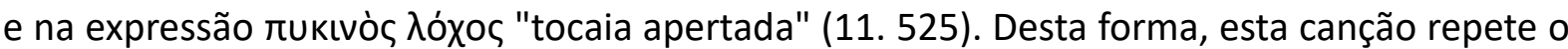
eixo temático das outras canções e do poema, uma vez que a emboscada, como observamos, representa uma forma de combate alternativa à batalha convencional, um recurso do qual se lança mão quando todas as outras alternativas convencionais se tiverem esgotado e no qual prevalece o emprego da astúcia ( $\mu$ ñtıఢ) por oposição à força $(\beta i ́ \alpha)\left({ }^{128}\right)$.

É possível perceber alguns dos padrões narrativos enumerados por DUÉ \& EBBOTT (2010, p. 69-70) na história do estratagema: (1) a escolha dos melhores para integrar a tropa que vai realizar a tocaia: "o grande cavalo... dentro do qual estávamos sentados/ os melhores

124 DE JONG (2001, p. 213).

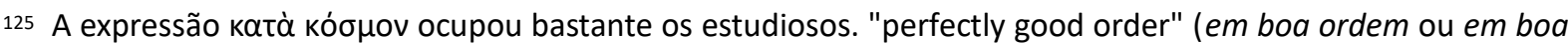
forma) costuma ser a tradução anglófona. Para discussão detalhada da expressão, ver FINKELBERG (1998); GONZÁLEZ (2013, p. 183-201 e sobretudo p. 194 n. 74).

126 Sobre o verbo $\mu \varepsilon \tau \alpha \beta \alpha i v \omega \omega \mu \tau \operatorname{s} \beta \eta \theta$ เ ver GIANNESI (2006), GONZÁLEZ (2013, p. 183-201, 393 n. 216)

127 Ver ANDERSON (2011b, p. 743-745) sobre o cavalo de madeira.

128 DUÉ \& EBBOTT (2010, p. 70). 


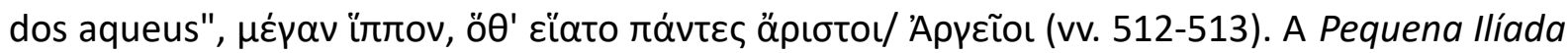
descreve haver espaço para somente treze homens (frag. 8 Bernabé = 12 West; Apolodoro, Epítome 5.14); Diomedes (Odisseia 4. 280) e Neoptólemo (Odisseia 11. 523-532) encontramse entre eles; (4) momentos de tensão: em outros lugares da Odisseia esse padrão narrativo encontra-se plenamente desenvolvido no episódio em que Helena aborda o cavalo e imita a voz das esposas dos guerreiros (4. 271-189). Na canção de Demódoco, a assembleia confusa dos troianos poderia suscitar semelhante sentimento, já que a descrição tem a focalização embutida (embbeded focalization) de Odisseu; (5) o ataque surpresa: é precisamente neste

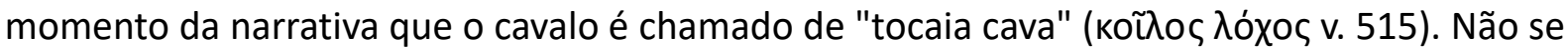

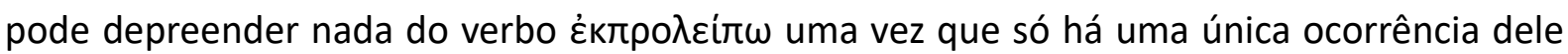

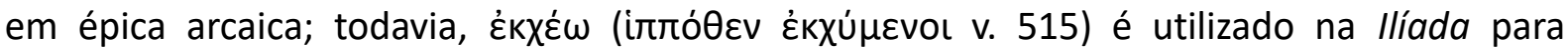
descrever o ataque dos mirmidões em seu retorno ao combate (Ilíada 16. 259). O ataque dessas tropas é comparado ao ataque de vespas que foram irritadas por meninos. JANKO (1994, p. 352) acredita que o estado de espírito das vespas é o termo de comparação. Porém, é importante notar que as vespas atacam aleatoriamente os transeuntes que passam perto delas desapercebidos, não apenas os meninos.

Passemos ao texto; Odisseia 8. 487-535:

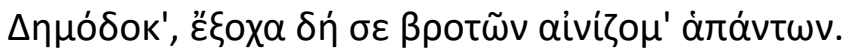

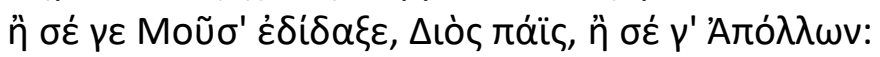

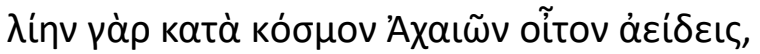

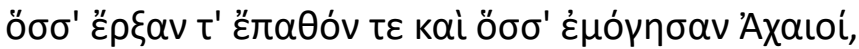

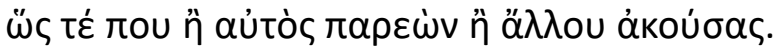

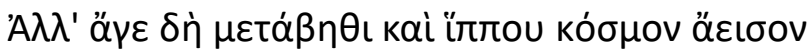

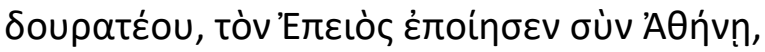

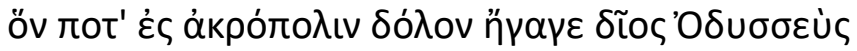

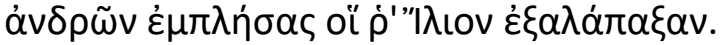

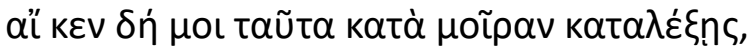

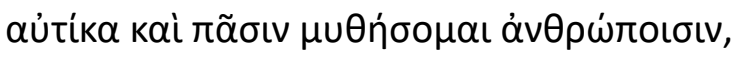

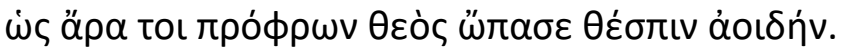

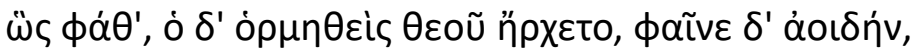

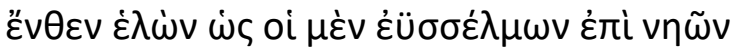

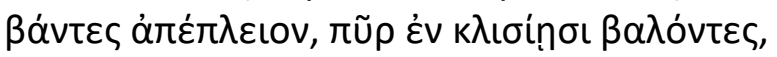

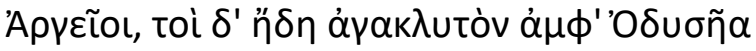

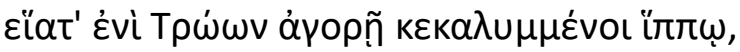

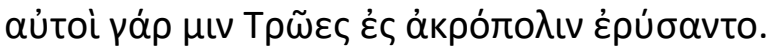




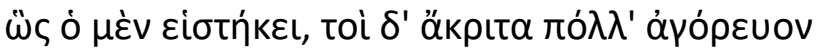

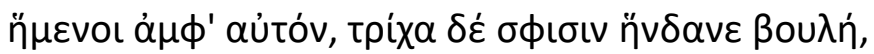

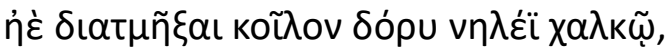

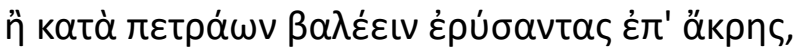

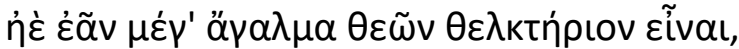

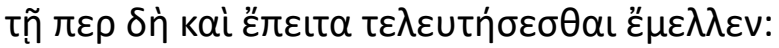

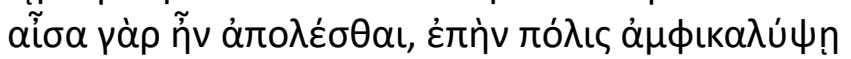

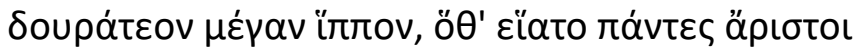

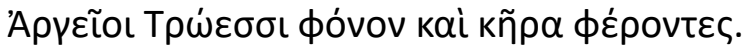

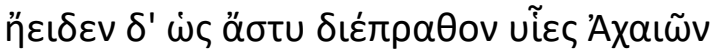

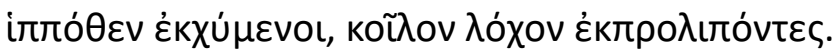

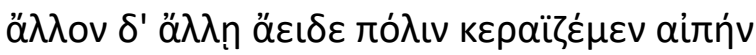

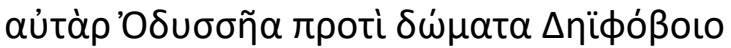

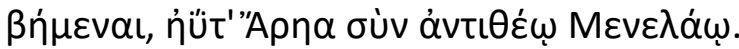

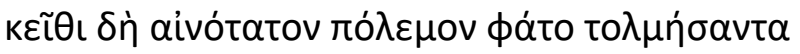

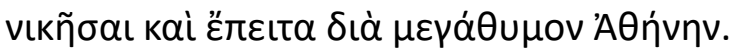

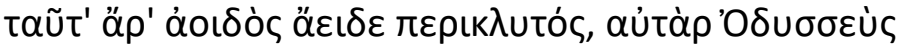

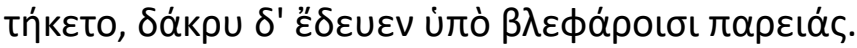

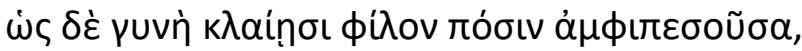

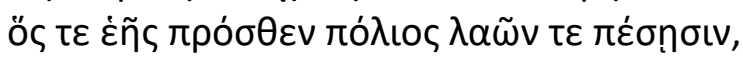

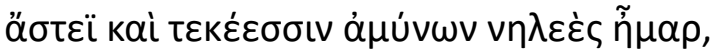

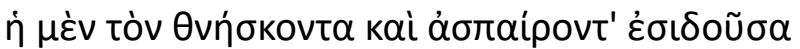

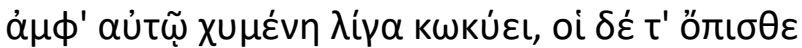

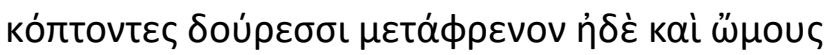

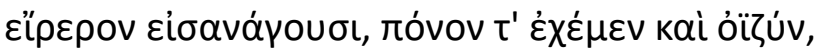

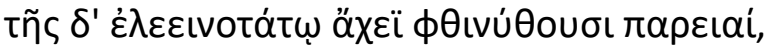

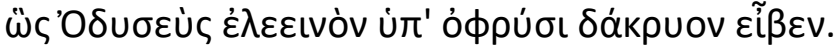

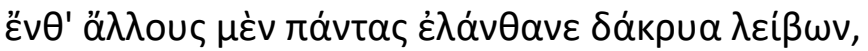

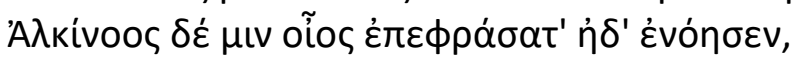

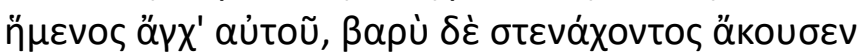

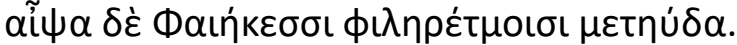

\section{A Demódoco disse então o astucioso Ulisses:}

'Demódoco a ti louvou eu mais que a qualquer outro homem, quer tenha sido a Musa a ensinar-te, quer o próprio Apolo. É com grande propósito que cantas o destino dos Aqueus tudo o que os Aqueus fizeram, sofreram e padeceram como se lá tivesses estado ou o relato ouvido de outrem. Mas muda agora de tema e canta-nos a formosura do cavalo de madeira, que Epeu fabricou com a ajuda de Atena: o cavalo que o divino Ulisses levou para a acrópole pelo dolo, 495 depois de o ter enchido com os homens que saquearam Ílio. Se estas coisas me contares na medida certa, direi a todos os homens que na sua benevolência 
o deus te concedeu a dádiva do canto inspirado'.

Assim falou; e o aedo, incitado, começou a preludiar o deus, revelando depois o seu canto; tomou como ponto de partida, o momento que tinham embarcado nas naus bem construídas e iniciado a navegação (depois de queimadas as tendas) os Aqueus. Outros, sob o comando do glorioso Ulisses, estavam na ágora dos Troianos, escondidos dentro do cavalo. Pois os próprios Troianos o tinham arrastado para a acrópole. E ali estava o cavalo enquanto os cidadãos se sentavam à volta discutindo de modo prolixo e confuso. Três planos Ihes agradaram: ou rachar a madeira oca com o bronze impiedoso; ou arrastá-lo até o cimo da cidade e atirá-lo para as rochas; ou deixá-lo ficar como oferenda encantadora para os deuses e foi isto o que acabou mais tarde por acontecer, pois era seu destino perecerem, quando a cidade circundasse o grande cavalo de madeira, dentro do qual estávamos sentados os melhores dos Aqueus para trazer aos troianos a morte e o destino. E cantou como os filhos dos Aqueus saquearam a cidade, entornando-se para fora do cavalo, deixando a oca cilada. Cantou como por caminhos diferentes arrasaram a íngreme cidade, mas Ulisses dirigiu-se, como se fosse Ares, à casa de Deífobo, na companhia de Menelau semelhante aos deuses: ai se diz que Ulisses ousou a mais terrivel das lutas, de que saiu vencedor com o auxílio da magnânima Atena. Foi este o canto do celebérrimo aedo, mas Ulisses derretia-se a chorar: das pálpebras as lágrimas umedeciam-lhe o rosto. Tal como chora a mulher que se atira sobre o marido que tombou à frente da cidade e do seu povo, no esforço de afastar da cidadela e dos filhos o dia impiedoso, e ao vê-lo morrer, arfante e com falta de ar, a ele se agarra, gritando em voz alta enquanto atrás dela os inimigos Ihe batem com as lanças nas costas e nos ombros para a arrastar para o cativeiro, onde terá trabalhos e dores, e murchar-lhe-ão as faces com o pior dos sofrimentos assim Ulisses deixava cair dos olhos um chora aflitivo.

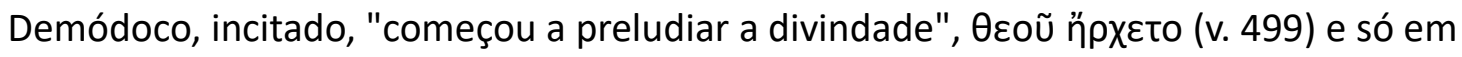

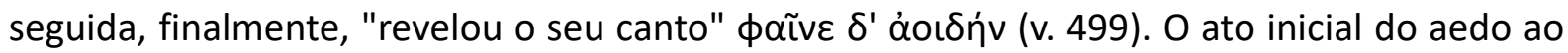
começar uma nova canção é, para traduzir literalmente, "começar pela divindade". Por causa dessa expressão, entende-se que Demódoco inicia a sua canção por um hino, do gênero dos hinos homéricos breves $\left({ }^{129}\right)$. O aedo não começa $a b$ ovo (pela construção do cavalo), mas in 129 HEUBECK (1998, p. 379), GARVIE (1994, p. 335), CLAY (1989, p. 7), THALMANN (1984 p. 122), FAULKNER 
medias res, instalando o exército dos aqueus no palco de guerra troiano $\left({ }^{130}\right)$ : "tomou como ponto de partida/ o momento em que tinham embarcado nas naus bem construídas", हैv $\theta \varepsilon v$

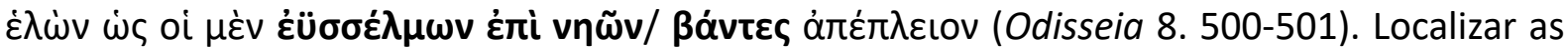
tropas no espaço é sempre importante nas narrativas de batalha; na tomada de cidades não é diferente, como temos observado. A Pequena llíada relatava que a frota dos gregos zarpou para Tênedo, enquanto os troianos, por sua vez, levam o cavalo para a cidade e festejam sua vitória aparente (arg. 230-236 Severyns). A Pequena llíada (frag. 11 Davies = 14 West), bem como o Saque de ílion (arg. 1-2 Severyns), sugere ambientação noturna.

Logo encontramos o nome de Odisseu: "outros, sob o comando do glorioso [Odisseu]

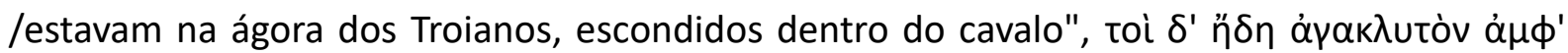

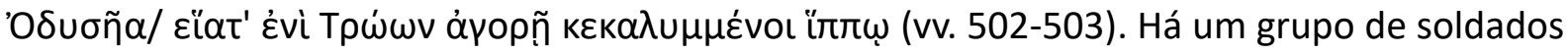
sob o comando de Odisseu, mas apenas ele é determinado pelo nome. Isto vai ao encontro dos relatos dos narradores-personagens examinados neste trabalho. Em geral, o narradorpersonagem refere-se às suas ações (às do exército) na primeira pessoa. Laerte, por exemplo,

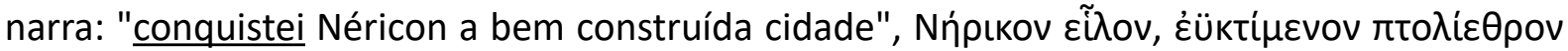

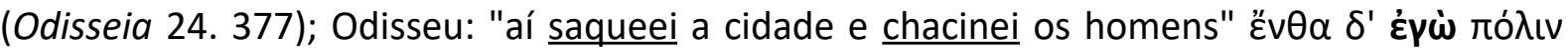

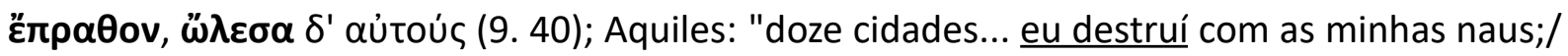
por terra afirmo [serem] onze na terra fértil de Troia", $\delta \omega \dot{\delta \varepsilon \kappa \alpha ~ \delta \eta ் ~ \sigma u ̀ v ~ v \eta u \sigma i ~ \pi o ́ \lambda \varepsilon เ \varsigma ~ a ́ \lambda ~} \alpha \dot{\pi} \alpha \xi '$

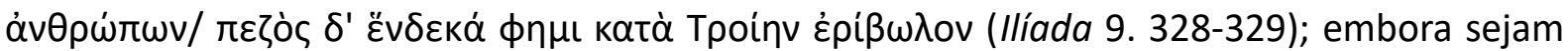
raras, analepses na primeira pessoa do plural ocorrem, mas bem pontualmente: "Fomos para Tebas, a sagrada cidade de Eécion/ saqueamo-la e de lá trouxemos os despojos"

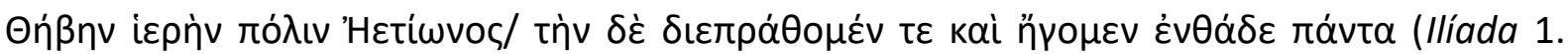
366-367). O uso do plural em Ilíada 4 designa Estênelo e Diomedes e não Estênelo e exército:

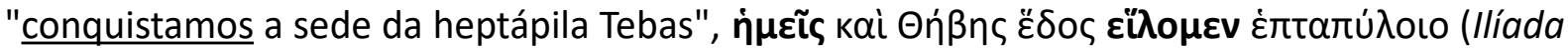
4. 406-407). O narrador também costuma escolher o comandante ou personagem principal como, por exemplo, nas narrativas sobre Aquiles em Tebas-sob-Placo, Lirnesso e Pédaso $\left.{ }^{131}\right)$. Mais adiante o narrador usará o plural para descrever a destruição de Troia ("cantou como os

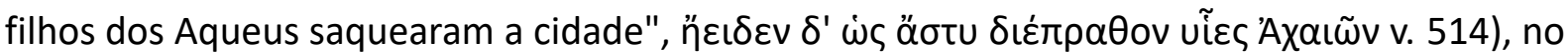

(2011, pp. 17-19), CLAY (2011, p. 249-250). Ver também Hesíodo, Teogonia 1, 36; Hino Homérico a Afrodite 293 (FAULKNER, 2008, p. 298); Ilíada 9.97; Píndaro, Nemeia 2.1-3, 3.10, 5.25.

130 DE JONG (2001, p. 190).

131 VAN WEES (1997, p. 671-672). 
entanto, não há dúvida de que Odisseu é a figura central deste relato.

Em seguida Demódoco narra as ações dos troianos. Eles discutem tumultuadamente as alternativas: abrir o cavalo no machado, lançá-lo do alto da cidade $\left({ }^{132}\right)$ ou aceitá-lo como oferenda aos deuses. Esta descrição é uma "focalização embutida" (embbeded focalization), a narrativa é como que "contaminada" pela percepção de Odisseu no interior do embuste do cavalo de madeira; além disso ela segue a estrutura da cena-padrão de deliberação indireta. Este tipo de cena-padrão tem duas formas: (1) delibera-se como fazer algo ou (2) delibera-se fazer uma coisa ou outra, como é o presente caso. Geralmente, a expressão formular üs äpa

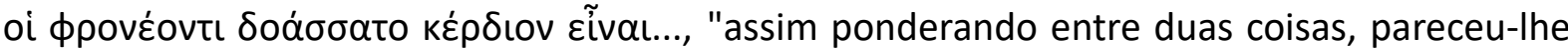
melhor tal solução..." aparece ao final, como tomada de decisão. As alternativas seguem um padrão: a primeira é emocional ou instintiva, enquanto a segunda é racional, a qual acaba sendo eventualmente escolhida $\left({ }^{133}\right)$. A descrição do destino de morte e destruição da cidade pelo artifício da prolepse é uma constante nas passagens relacionadas a este tema: "e foi isto

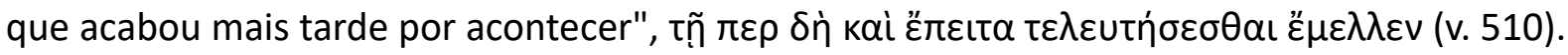
A escolha neste trecho, entretanto, é justificada em termos de destino ( $\alpha \tilde{i} \sigma \alpha$ v. 511) cujas condições os troianos acabam por satisfazer (v. 511-513).

A canção tem um recomeço no verso "cantou como os filhos dos Aqueus saquearam a

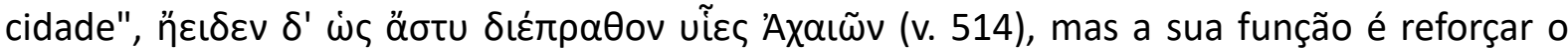
princípio do saque e a narrativa efetiva dos eventos que levam à destruição da cidade.

Os guerreiros deixam o interior do cavalo e adentram a cidade. O verso "cantou como

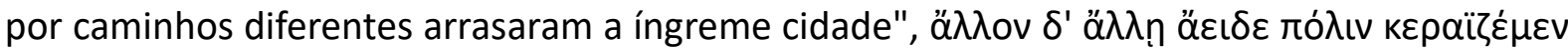
airńv (v. 516), além de aparentar uma descrição panôramica, daquelas usadas pelo narrador homérico para descrever o teatro de guerra antes de fechar o foco narrativo sobre um herói particular $\left({ }^{134}\right)$, sugere a divisão dos integrantes do grupo em duplas ou grupos menores com o propósito de realizar ataques em locais diferentes. Este padrão narrativo está presente na Ilíada e é usado no episódio do ataque troiano às muralhas do acampamento: "e organizados

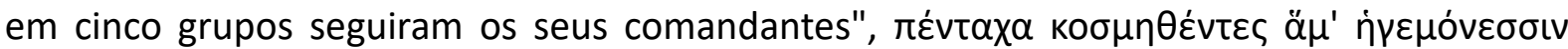
ع̈rovto (Ilíada 12.87). Este trecho encontra-se em llíada 12.88-107:

\footnotetext{
132 Ver a discussão em HEUBECK (1998, p. 380)

133 De JONG (2001, p. 96), GARVIE (1994, p. 336).

134 Supra, p. 47.
} 


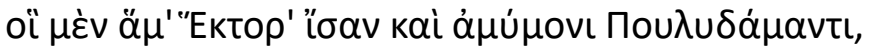

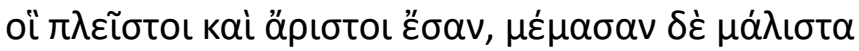

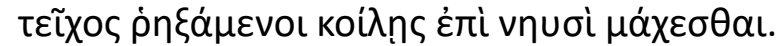

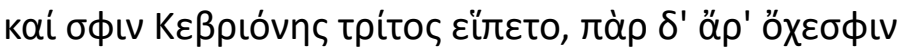

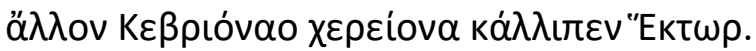

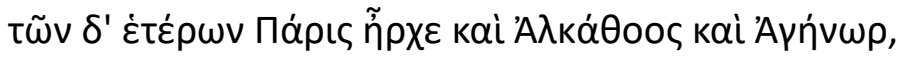

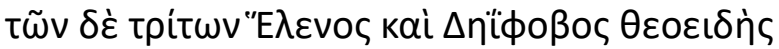

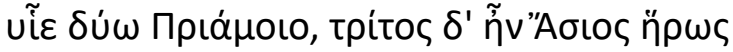

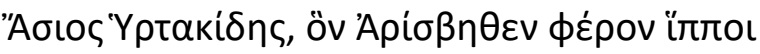

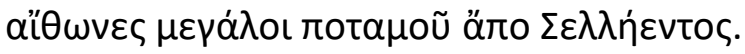

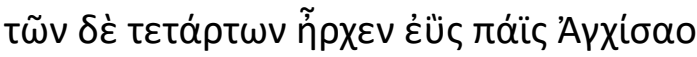

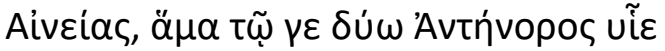

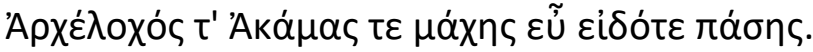

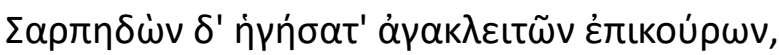

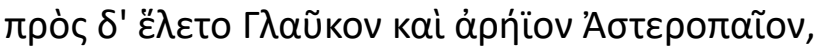

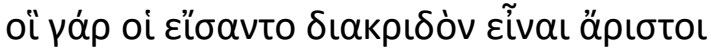

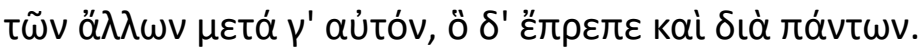

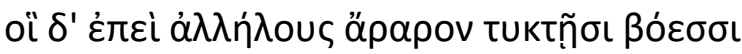

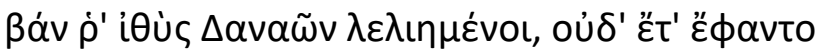

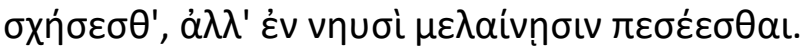

Uns foram atrás de Heitor e do divino Polidamante, os que eram melhores e mais numerosos, ávidos de romper a muralha e combater junto das côncavas naus. Com eles seguia como terceiro Cebríones; e junto do carro deixara Heitor outro homem, mais fraco que Cebríones. O segundo grupo lideravam Páris e Alcátoo e Agenor; o terceiro grupo, Heleno e o divino Deífobo, ambos filhos de Príamo; e como terceiro estava o herói Ásio, Ásio filho de Hírtaco, a quem de Arisbe os grande e fulvos cavalos haviam trazido, de junto do rio Seleis. O quarto grupo era liderado pelo valente filho de Anquises, Eneias; e com ele seguiam os dois filhos de Antenor, Arquéloco e Acamante, peritos em todo o tipo de combate. Sarpédon conduzia os famigerados aliados e escolheu como seus camaradas Glauco e o belicoso Asteropeu; pois estes pareceram-Ihe ser os mais valentes dos outros todos, além de si próprio; ele que sobressaía entre todos. Depois que posicionaram na formação os escudos de pele de boi, arremeteram com afinco contra os dânaos, convencidos de que já não seriam retidos, mas que cairiam sobre as escuras naus. 
Não seria exagero imaginar que, se preciso e se assim o desejasse, o narrador poderia lançar mão desta estratégia narrativa para constituir grupos ou duplas que posteriormente atacariam alvos troianos em separado. Este padrão, presumivelmente, poderia ser usado na organização da estrutura da narrativa da destruição de Troia no poema Saque de ílion $\left({ }^{135}\right)$. Se dermos importância às nossas fontes, pouco seguras, mas que refletem um material mais ou menos tradicional $\left({ }^{136}\right)$, esta forma organizacional da narrativa parece plausível: Neoptólemo mata Príamo no interior do templo de Zeus; Menelau mata Deífobo e reencontra Helena; Ájax estupra Cassandra no templo de Atena; Odisseu mata Astíanax (arg. 11-18 Severyns; Apolodoro, Epítome 5.20-23; Pausânias 10.25) $\left({ }^{137}\right)$. Há um paralelo na llíada em que os troianos se dividem em cinco pelotões. Estes grupos, arranjados em torno de comandantes, combatem isoladamente, em diferentes pontos da muralha dos aqueus. Em determinado momento, o narrador sumariza da seguinte forma o enfrentamento: "os outros combatiam junto aos outros portões... Foi então que o filho de Pirítoo, o possante Polipetes", ä $\lambda \lambda$ o $\delta^{\prime}$

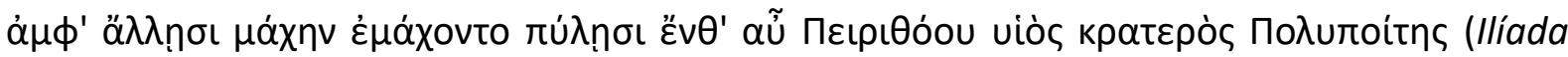
12. 175, 182). um verso sintetiza a ação narrada até aquele ponto e o outro começa um novo núcleo narrativo em torno da figura de Polipetes $\left({ }^{138}\right)$. Há outro exemplo elucidativo: "[outros lutavam noutros lugares] em meio às naus/ mas Heitor fez-se imediatamente ao glorioso

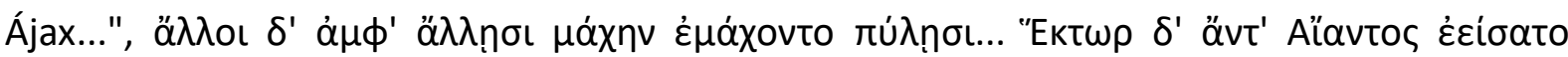

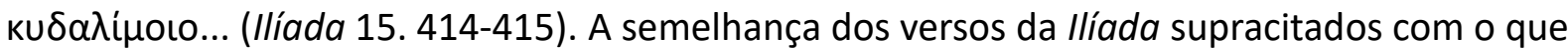
encontramos na Odisseia é grande e podemos conceber uma narrativa da saque em que cumprissem uma função parecida.

O foco narrativo se volta então para Odisseu: "mas [Odisseu] dirigiu-se, como se fosse

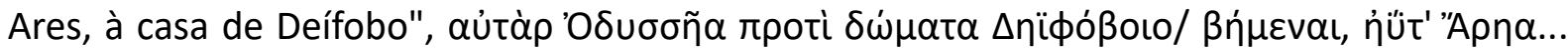
(Ilíada 8. 517-518). Ele está acompanhado de Menelau, na companhia do qual já visitara Troia anteriormente, no episódio da embaixada (llíada 3. 203-224). Podemos imaginar que numa narrativa desenvolvida hipotética deste ataque, personagens que tiveram algum contato com a dupla antes reaparecessem, para o seu mal ou para o seu bem. Entretanto, é

135 Ver ANDERSON (2011a, pp. 743-745) e FINGLASS (2014, pp. 347-354) sobre o poema. SAMMONS (2017, pp. 72-76) imagina uma apresentação catalógica do grupo dentro do cavalo, depois uma narrativa de batalha catalógica, semelhante à emboscada que Odisseu prepara para os pretendentes no palácio.

136 KELLY (2014 pp. 326-328).

137 FINGLASS (2014, pp. 347-354).

138 Ver CLAY (2011, pp. 56-68). 
importante notar o local para onde Odisseu se desloca e o adversário que lá encontra: Deífobo. Este troiano era filho de Príamo e irmão de Heitor e de Páris Alexandre. Deífobo é mencionado na Odisseia, também em um episódio relacionado ao cavalo de madeira (4. 276), do qual é possível inferir que o troiano teria se casado com Helena depois da morte de Alexandre (Pequena Ilíada arg. 216 Severyns). Na ausência de Heitor e Alexandre, podemos considerar Deífobo o adversário troiano mais forte e, portanto, o campeão troiano. Por isso:

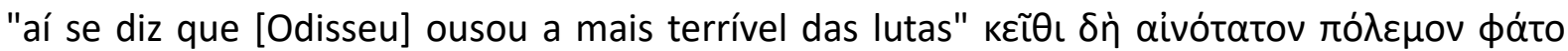

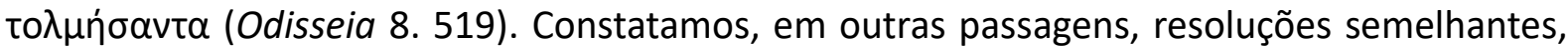

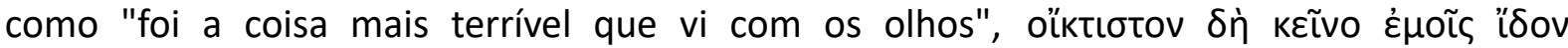
óфӨ $\alpha \lambda \mu$ ог̃ (12. 258), o comentário de Odisseu como conclusão do embate contra Cila; ou Glauco, encerrando a sua história sobre os sólimos: "diz ele ter sido aquela a maior batalha

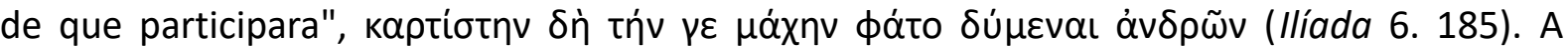

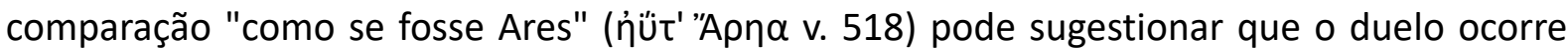
em uma aristeia $\left({ }^{139}\right)$, exatamente como o duelo entre Aquiles e Heitor (Ilíada 22. 214-366). A intervenção de uma divindade, apesar de aqui ser mencionada apenas para salientar o favoritismo do herói, poderia também estar ligada a esse contexto.

Assim termina a brevíssima narrativa da tomada de Troia, ou a narrativa da narrativa, uma vez que o narrador mais descreve a narrativa do personagem-narrador do que a narra de fato. Finda a canção, o narrador descreve a reação do herói: "mas [Odisseu] derretia-se a

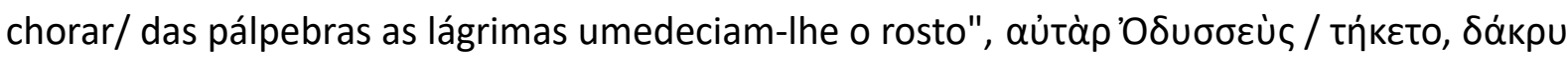

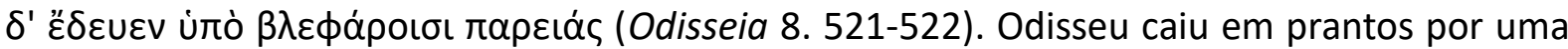
segunda vez neste episódio, após outra canção sobre a Guerra de Troia, porém desta vez não cobre o seu rosto. O verbo tท́кєto "derreteu-se" é de uma expressão muito intensa e só se aplica outra vez no poema a Penélope $(19.204,207)\left({ }^{140}\right)$. Porém, as emoções de Odisseu são ilustradas com maior precisão pelo símile que o compara a uma cativa de guerra.

Este é um dos símiles mais impressionantes e comoventes da poesia épica arcaica e descreve uma situação encontrada em outras passagens, a da esposa que assiste, desde as muralhas ou da cidade, o marido ser morto em combate. Andrômaca, por exemplo, soube da morte do marido por causa dos gritos desesperados dos troianos, mas ainda assim chegou às 
muralhas a tempo de ver o seu cadáver ser arrastado pelos cavalos de Aquiles: "pôs-se de pé na muralha [espreitando] - e depois viu Heitor/ sendo arrastado à frente da cidade" عૈotn

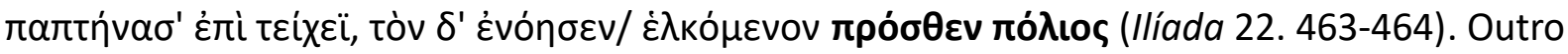
exemplo pode ser verificado no lamento de Briseida para Pátroclo: "vi [meu marido] à frente

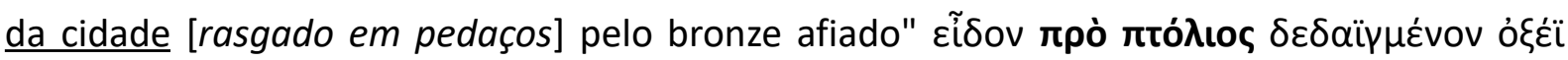
$\chi \alpha \lambda \kappa \tilde{\omega}$ (Ilíada 19. 285). Assim também é a cena retratada no símile. Odisseu chora "Tal como chora a mulher que se atira ao marido/ que tombou à frente da cidade e do seu povo", $\dot{\omega} \varsigma \delta \dot{\varepsilon}$

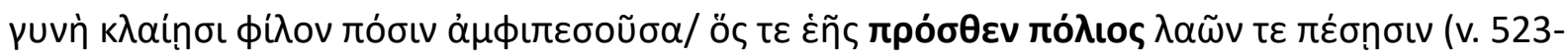
524). Porém, diferente da cena descrita no símile, parece haver em ambos os paralelos certa ênfase na mutilação do cadáver, principalmente na cena de Andrômaca, em que o narrador concentra-se na velocidade e brutalidade dos animais: "cavalos velozes/ o arrastavam sem

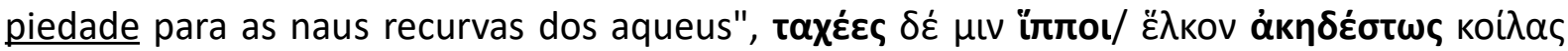

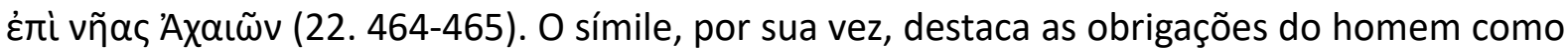
cidadão e marido: "que tombou à frente da cidade e do seu povo, no esforço/ de afastar da

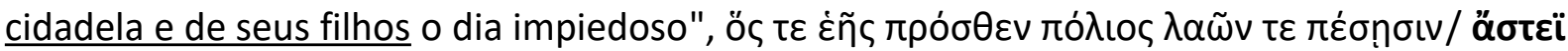

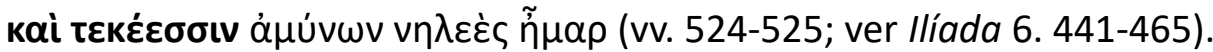

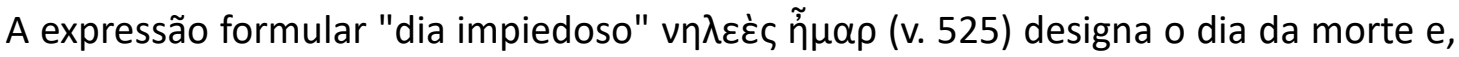
mais especificamente, a morte em situação de combate, como atestam todas as ocorrências

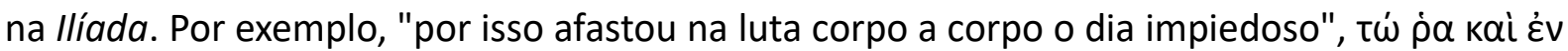

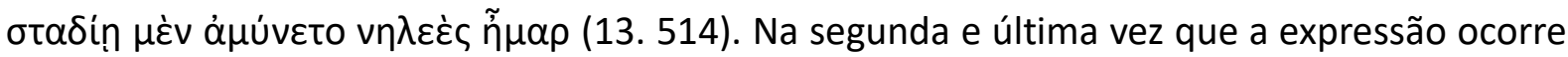
na Odisseia, o seu sentido parece algo genérico, como "risco", simplesmente (Odisseia 9. 17). Entretanto, dado o contexto, deve ser uma referência ao assassinato em massa das crianças; talvez à escravização de mulheres e crianças. Há duas referências ao assassinato de crianças nos poemas homéricos. A primeira encontra-se em um discurso furioso de Agamêmnon para Menelau, que hesitava em matar um inimigo: "que nenhum deles fuja da íngreme desgraça/

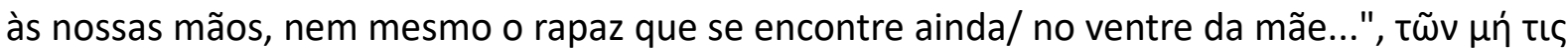

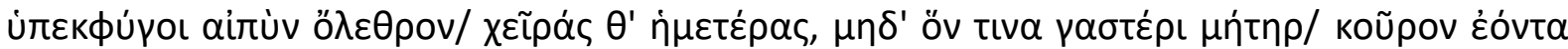
фદ́poı (Ilíada 6. 57-59); a outra encontra-se em um lamento de Príamo: "[tálamos dizimados]

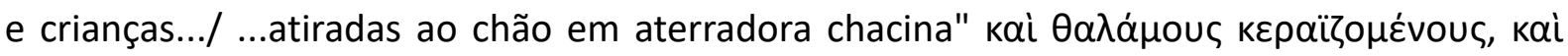

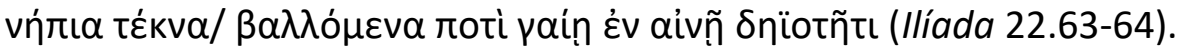


Pelo modo como o símile sucede, resta evidente que o marido (campeão da cidade?) falhou. Estas cenas são particularmente impactantes e concentram significado simbólico. Em Ilíada 22. 463-474, por exemplo, Andrômaca desfalece ao ver o cadáver do marido arrastado pelos cavalos de Aquiles. Ela atira para longe um (complicado) adorno de cabeça que inclui diadema, touca, lenço, laço e véu. As lentes do narrador se concentram no véu, um presente

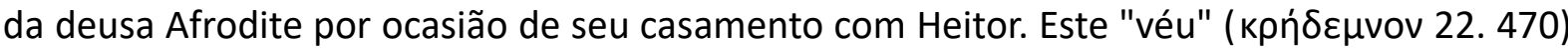
adquire uma dimensão simbólica na medida em que esta palavra também designa a parcela superior das muralhas de uma cidade. A queda do véu simboliza a destruição de Troia. Assim, também o verso proferido por Aquiles em Ilíada 16. 100 adquire dimensão simbólica: "...que nós dois sobrevivêssemos, para que sozinhos soltássemos da sacra Troia o [véu]", vw̃̈̈v $\delta^{\prime}$

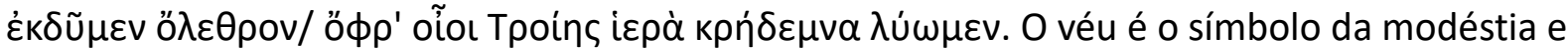
de decência das mulheres homéricas; retirar (à força) o véu, equivale ao estupro, assim como soltar o véu de uma cidade, equivale ao seu saque e destruição $\left({ }^{141}\right)$.

Os dois versos seguintes do símile descrevem o comportamento da mulher: "e ao vê-

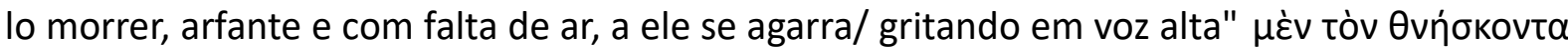

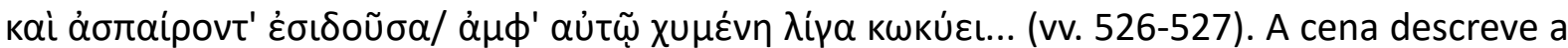
ação pouco mais ou menos ritual do lamento fúnebre. O verso 527 também é empregado na descrição de Briseida em Ilíada 19.284 quase na íntegra, devido à expressão formular $\alpha \dot{\mu} \phi^{\prime}$

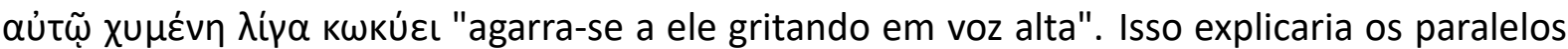
recorrentes entre os lamentos e as descrições do destino da população não-guerreira.

O soldados interrompem o lamento da mulher dando golpes com a banda da lança. A descrição da mulher enlutada, viúva, transforma-se agora numa descrição de escravização: "para a arrastar para o cativeiro onde terá trabalhos e dores/ e murchar-lhe-ão as faces com

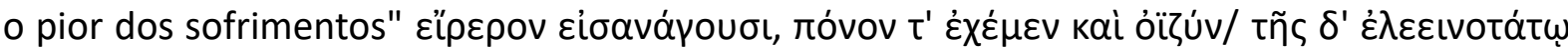

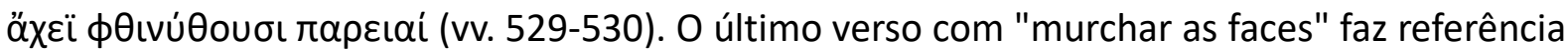
ao choro e retorna à ideia inicial, o termo de comparação que iniciou o símile. Há por óbvio, uma reversão: sitiante/sitiado, conquistador/escravizada, homem/mulher $\left({ }^{142}\right)$, que extrapola a perspectiva negativa ordinária do restante dos veteranos da guerra no poema. Isto é, além

\footnotetext{
141 Ver NAGY (2013, pp. 109-145) para um estudo das ligações (frequentes na tragédia) entre o matrimônio e a morte, e entre Ares e Eros. Sobre o "véu" ver DE JONG (2012, p. 183); principalmente NAGLER (1974, pp. 4560); LLEWELLYN-JONES (2003, pp. 215-258).

142 Ver FOLEY (1978) sobre este tipo de comparação "reversa".
} 
de entender o sofrimento que a guerra lhe causou, Odisseu se mostra capaz de se colocar no lugar dos vencidos e entender o sofrimento que ele, como vencedor, Ihes causou $\left({ }^{143}\right)$.

\subsection{CÁLIDON E PLÊURON}

Depois de Aquiles se retirar de campo de batalha, as tropas dos troianos pressionam cada vez mais o exército dos aqueus. Eles adotam a sugestão de Nestor (Ilíada 7. 326-345) e constroem uma muralha ao redor do acampamento para tentar conter o avanço dos troianos (Ilíada 7. 433-441). Zeus está cumprindo o pedido de Tétis: "concede a primazia aos Troianos

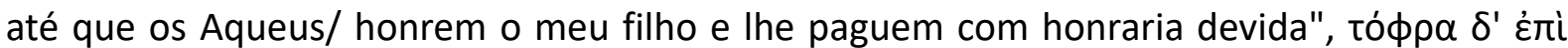

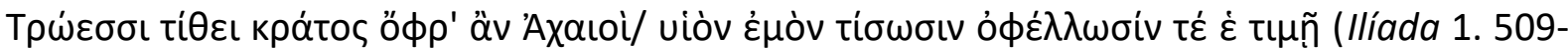
510). Agamêmnon, desesperado com as seguidas derrotas e com o fato de troianos estarem acampando pela primeira vez fora das muralhas, convoca uma assembleia (llíada 9. 1-88). A sua proposta: bater em retirada. Diomedes e Nestor contornam esta situação vexatória. Mais tarde, em outra reunião entre os líderes, Agamêmnon admite o erro de ter tomado Briseida e prepara uma longa lista de presentes, para serem concedidos imediatamente, outros por ocasião do saque da cidade dos troianos, outros ainda quando do retorno, caso Aquiles volte para o campo de batalha e ajude os aqueus. Porém, Agamêmnon pede o reconhecimento da sua superioridade hierárquica da parte de Aquiles (Ilíada 9. 89-181).

Então, Nestor escolhe os embaixadores mais adequados para levarem a proposta ao herói: Odisseu, cujas habilidades retóricas e oratórias são explicitadas em Ilíada 3. 203-224; Ájax, que ganhou relevo em llíada 7 graças ao duelo com Heitor e o qual o narrador iliádico considera o melhor dos aqueus na ausência de Aquiles: "quanto a homens, o melhor era

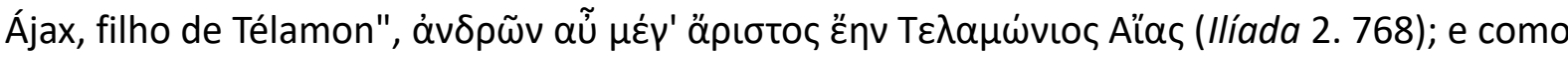
o derradeiro integrante do grupo, Nestor escolhe Fênix, sobre o qual a llíada até aqui nada falara. Ele é apresentado mais adiante como tutor de Aquiles (em outras multiformas esta função cumpre o centauro Quíron; ver a llíada 4. 219; 11. 830-832; 16. 143). Deste ponto em diante o episódio narrado torna-se uma cena (muito longa) de hospitalidade, estruturada da seguinte forma: a embaixada é recepcionada na tenda de Aquiles (Ilíada 9. 182-221); depois

143 Esta forma de reversão vencedor/vencido também aparece na llíada (24.471-551) no encontro de Aquiles e Príamo. Ver MACLEOD (1982, p. 8-16) e (2001) para um estudo desta cena. 
de saciar o desejo de comer e beber, os oradores tentam persuadir o herói: (1) discurso de Odisseu e resposta de Aquiles (vv. 222-431); (2) discurso de Fênix e resposta de Aquiles (vv. 432-622); (3) discurso de Ájax e resposta de Aquiles (vv. 623-655). Depois dos discursos e réplicas, os integrantes da embaixada retornam para aos aqueus para dar a notícia, com a exceção de Fênix, que permanece na tenda.

O discurso de Fênix para Aquiles pode ser divido em três partes: em llíada 9. 434-495, Fênix conta a sua biografia para se estabelecer como autoridade digna de ser ouvida (notar o

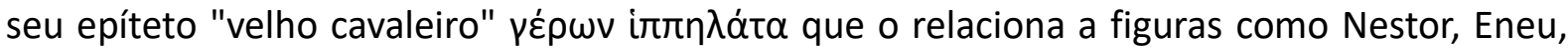
Peleu). Em Ilíada 9. 496-523 Fênix conta uma alegoria (HAINSWORTH, 1993, p. 119) sobres as Súplicas (^ıtai). Seu principal ponto é que mesmo os deuses se deixam dobrar por súplicas e que, dessa forma, seria uma postura arrogante de Aquiles não aceitá-las. Na terceira parte, em Ilíada 9. 524-605, o tutor de Aquiles narra um exemplum sobre Meleagro e a experiência de quase destruição da cidade de Cálidon, que estudaremos abaixo.

Esta narrativa de quase destruição envolve duas cidades etólias que na llíada servem de ponto de referência para toda a região ("na Plêuron e na íngreme Cálidon", $\Pi \lambda \varepsilon \cup \rho \tilde{\omega} v \iota$ kai

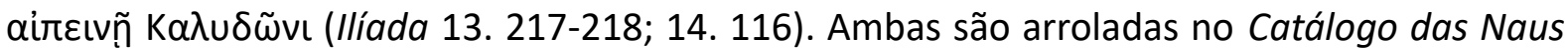
no contingente comandado por Toas, filho de Andrêmon (Ilíada 2. 639-640); e na ausência de Eneu, dos filhos de Eneu e de Meleagro, este herói reinava sobre todos os etólios. Plêuron é mencionada, por meio da indicação do nome, somente nestas ocasiões na llíada, entretanto a cidade ganha relevo no poema, neste episódio, como a cidade natal dos curetes. Sabemos por fontes de tradições tardias que Téstio, o rei dos curetes, estabeleceu uma aliança com a cidade de Cálidon pelo casamento de sua filha, Alteia, com o rei Eneu (Ésquilo, Coéforas, 602, 606; Eurípides, Ifigênia em Aulis, 49). Meleagro, um dos protagonistas desta história, é filho deste casal $\left({ }^{144}\right)$.

A cidade de Cálidon, além de "íngreme", é caracterizada como "rochosa" ( $\varepsilon \tau \rho \eta ́ \varepsilon \sigma \sigma \alpha$ llíada 2. 640) e "agradável" (દ̇pavvń llíada 9. 577). Ela não é mais popular do que Plêuron, de forma que estaríamos autorizados a considerá-las algo obscuras, não fosse por este episódio.

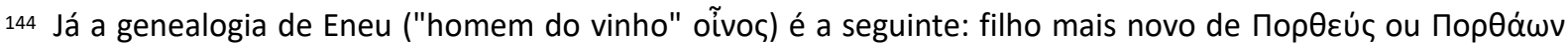
("demolidor", 14.155-157) e Eurite (Hesíodo, Catálogo das Mulheres, 10a52 Melkerbach-West $=10.52$ Most); é bisavô de Diomedes; tem quatro irmãos (schol. bT ad llíada 14.116; Hesíodo, Catálogo das Mulheres, 10a52-54 Melkerbach-West = 10.52-54 Most). Meleagro é filho de Alteia; Tideu, de Peribeia. Ver $\operatorname{ALDEN}(2011$, p. 596), EDER (2011, p. 675), GANTZ (1993, p. 328-335). 
Provavelmente no contexto do festival de primeira colheita, Eneu se esquece de dedicar as primícias de seu pomar à deusa Ártemis. Enfurecida, ela encaminha um javali para o pomar, lavouras e demais propriedades de Cálidon como forma de punição. O javali causa enormes prejuízos para a cidade e nenhum caçador consegue matá-lo, muito pelo contrário: morrem antes em grande número e sem lograr nenhum sucesso. Assim, Meleagro forma um grupo seleto de heróis provenientes de várias cidades para caçar o animal, que ele mesmo destrói. Este episódio fica conhecido na mitologia greco-romana como a caçada ao javali de Cálidon $\left({ }^{145}\right)$. O catálogo dos heróis que teriam tomado parte na caçada é grande, incluindo Meleagro, Drias, Idas, Linceu, Cástor e Polideuces, Teseu, Admeto, Jasão, Íficles, Pirítoo, Peleu, Télamon, Atalanta, Anfiarau, entre outros (Apolodoro, Biblioteca, 1.8; Higino, Fábulas, 173; Ovídio, Metamorfoses, 7. 270 ss.) $\left({ }^{146}\right)$.

A divisão dos despojos do animal, todavia, ocasiona uma desavença que rapidamente se transforma em batalha campal entre os etólios de Cálidon e os curetes de Plêuron, como a Discórdia: "ela que primeiro levanta um pouco a cabeça, mas depois/ fixa a cabeça no céu

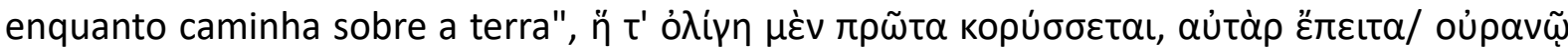

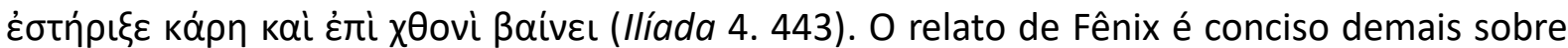
este ponto, todavia é possível que a discórdia tenha surgido inicialmente entre Meleagro e os seus tios, os irmãos de Alteia (Baquílides 5. 127-135; Ovídio, Metamorfoses, 8. 425-444). Os padrões narrativos envolvendo disputas, mortes acidentais, no contexto de caçadas de javali e de outros animais são numerosos na literatura antiga. Um exemplo pode ser encontrado na Odisseia, na analepse na caçada do javali como ritual de iniciação do jovem Odisseu (19. 413466). Nesta passagem, porém, Odisseu e os filhos de Autólico (os seus tios maternos) fazem uma divisão justa dos espólios do javali e tratam o ferimento que Odisseu recebeu do animal sem que haja qualquer forma de desentendimento $\left({ }^{147}\right)$.

É impossível qualquer especulação sobre os motivos que teriam levado os habitantes de Cálidon e Plêuron à discordância na narrativa de Fênix como, por exemplo, podemos fazer no caso de Aquiles e Agamêmnon (Ilíada 1. 53-305), todavia, o relato parece apresentar os curetes no papel dos agressores: "combatiam os curetes e os etólios tenazes em combate/

145 GANTZ (1993, p. 331)

146 Ver CABRAL (2013, pp. 53-54).

147 Ver ALDEN (2011a, pp. 430-431). 


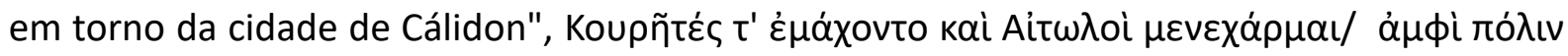

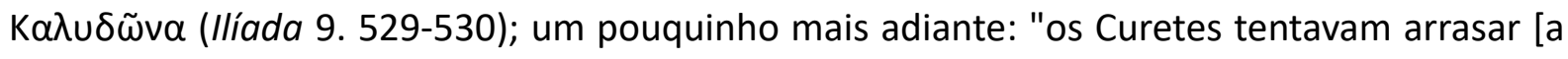

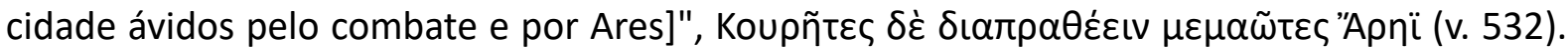
Por óbvio, isto coloca Meleagro na posição de campeão defensor e a focalização narrativa do relato na dos sitiados.

A partir deste ponto o propósito parenético e paradigmático da narrativa de Fênix se torna evidente: "enquanto combatia Meleagro, diletos de Ares/tudo corria mal aos Curetes",

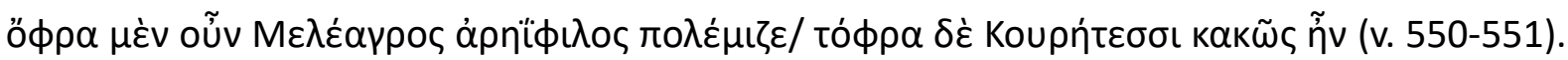
Esses versos traçam um paralelo entre a excelência guerreira e a importância de Aquiles e de Meleagro para o seu exército e a sua cidade. Como observa HAINSWORTH (1993, p. 134) em seu comentário a este discurso da llíada, é exatamente esta necessidade de aproximação dos heróis que torna o relato obscuro neste ponto. Cálidon é a cidade em estado de sítio, mas os versos seguintes apresentam os curetes acuados dentro das muralhas: "nem podiam estar/

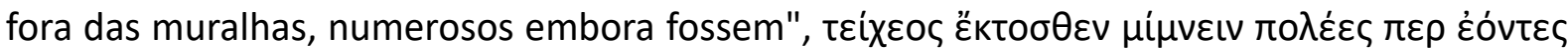
(v. 552). HAINSWORTH (1993, p. 134) imagina um cenário em que os curetes constroem uma muralha ao redor do seu bivacampamento, nas imediações de Cálidon, exatamente como os aqueus são forçados a fazê-lo em llíada 7, porém, admite que nada no contexto sugere essa interpretação.

Meleagro mata um dos tios maternos durante os combates. A reação de Alteia recebe

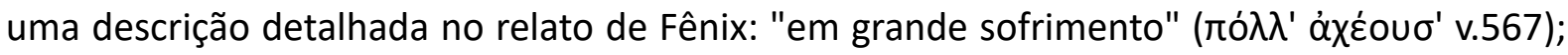

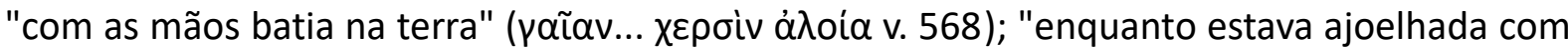

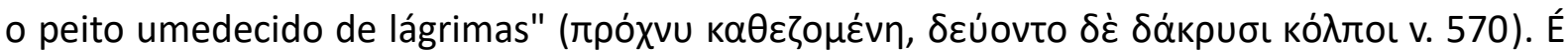
desta maneira que Alteia lança uma maldição sobre Meleagro, "invocando os deuses" ( $\theta \varepsilon$ oĩoı

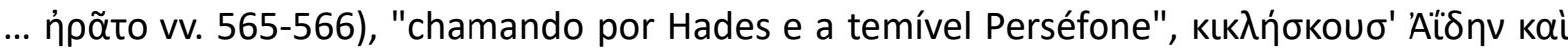

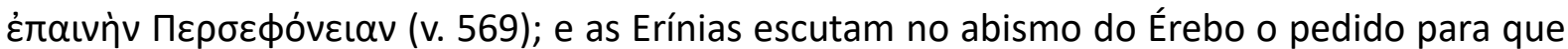

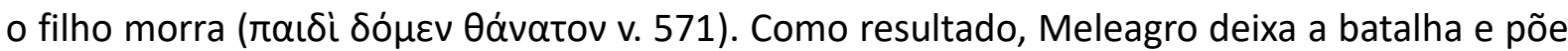
a perder qualquer perspectiva de vitória dos etólios de Cálidon.

Tal como Aquiles, tomado pela raiva ( $\mu$ ñvıs) provacada pelos abusos de Agamêmnon,

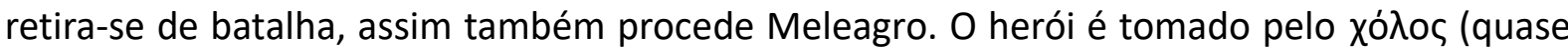

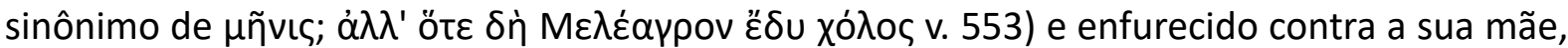




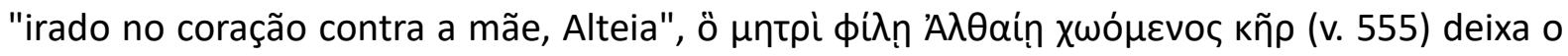
campo de batalha para ficar junto a sua esposa Cleópatra (uma inversão dos elementos que compõe o nome de Pátroclo).

Assim como na llíada, os habitantes de Cálidon, desesperados com a possibilidade de terem sua cidade saqueada e destruída pelos curetes, enviam uma embaixada, composta por anciãos, sacerdotes. Os sacerdotes oferecem a Meleagro grosso modo uma extensão para a

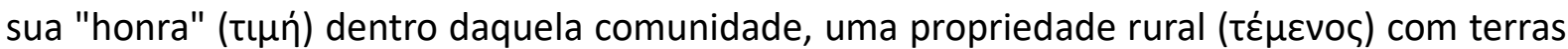
de altíssima qualidade, como sinal de sua importância para o grupo que carece mais do que nunca de sua excelência guerreira "um lindíssimo terreno/ de cinquenta jeiras - metade dele

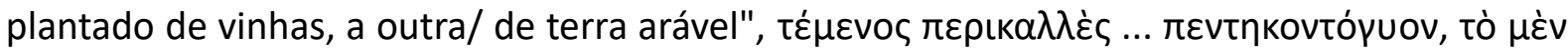

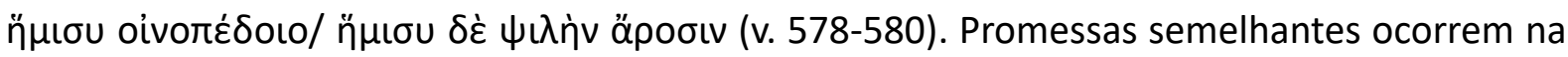
Ilíada como, por exemplo, cogita Aquiles ao imaginar as razões pelas quais Eneias estaria se arriscando em batalha: "será que os Troianos te demarcaram um domínio senhorial, superior

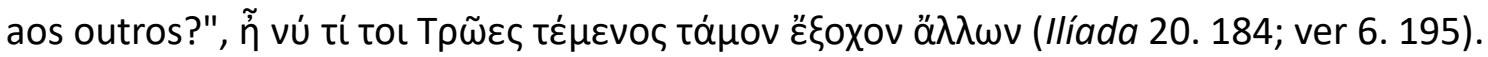

Aos sacerdotes de Cálidon logo se juntam membros do círculo mais íntimo do herói, com os mesmos pedidos; primeiramente o pai de Meleagro e rei de Cálidon, Eneu, suplica de joelhos que o filho retorne à luta: "agitando as portas bem ajustadas, ajoelhou-se perante o

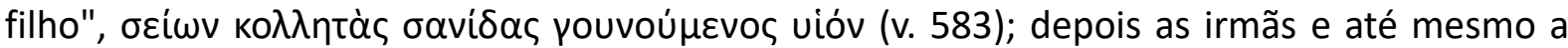
mãe suplicam sem sucesso. Após o núcleo familiar, os companheiros e amigos mais íntimos conversam com Meleagro, situação que estabelece um paralelo com a tenda de Aquiles e os companheiros Odisseu, Fênix e Ájax. Meleagro só retorna ao combate depois dos apelos da esposa Cleópatra, em tempo ainda de salvar a cidade do saque e do arrasamento pelas mãos dos curetes, todavia, tarde demais para que as promessas dos habitantes de Cálidon fossem de fato cumpridas.

Eis a passagem, na íntegra, em Ilíada 9. 524-604:

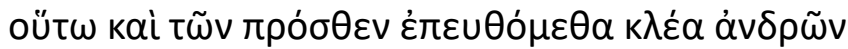

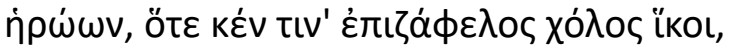

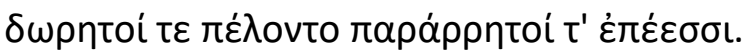

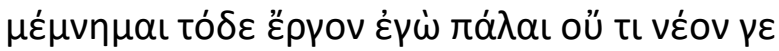

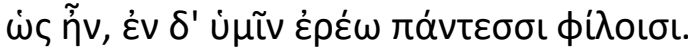

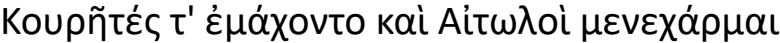




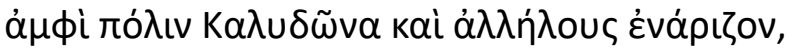

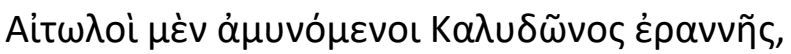

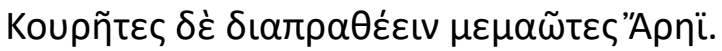

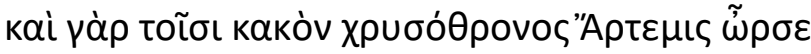

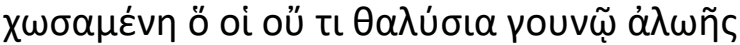

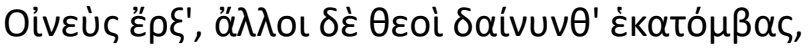

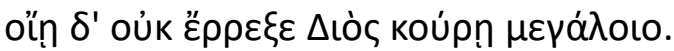

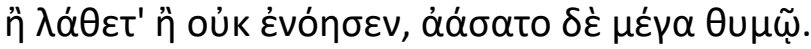

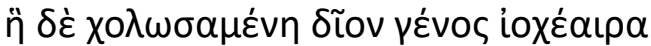

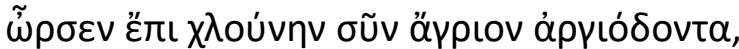

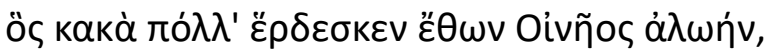

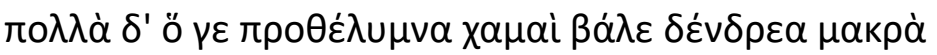

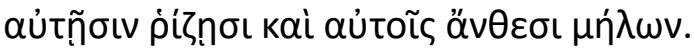

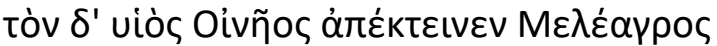

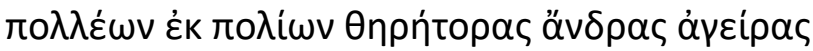

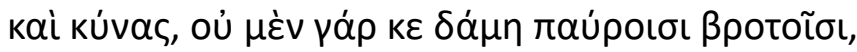

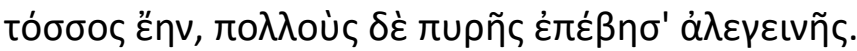

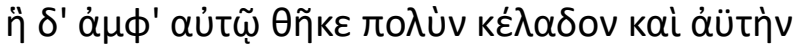

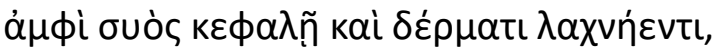

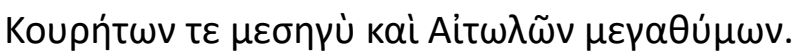

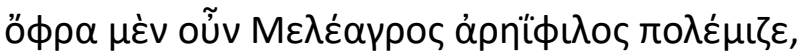

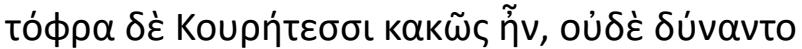

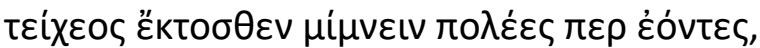

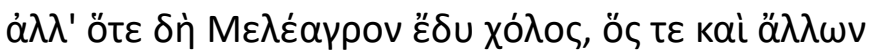

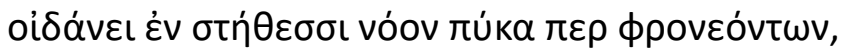

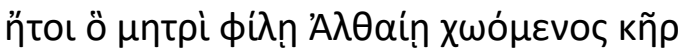

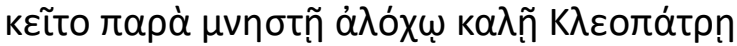

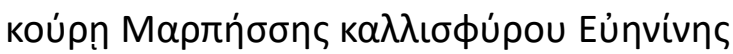

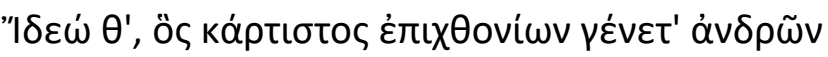

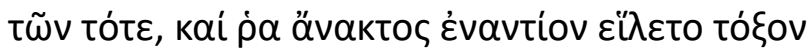

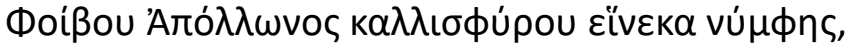

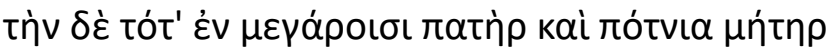

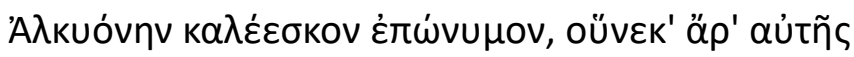

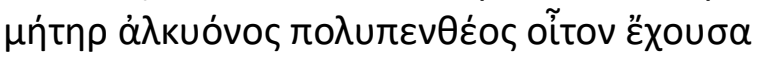

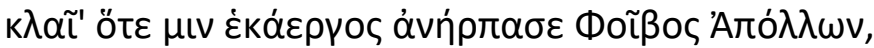

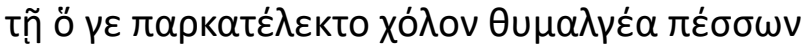

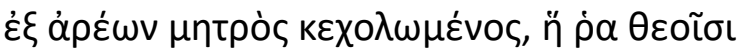

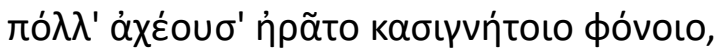

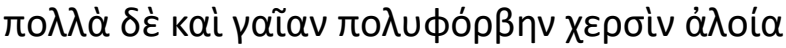

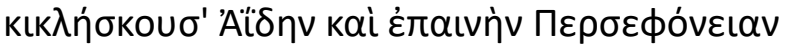

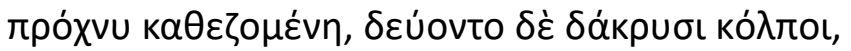

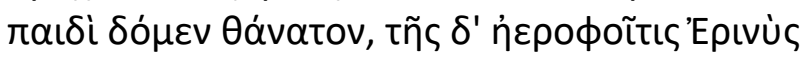

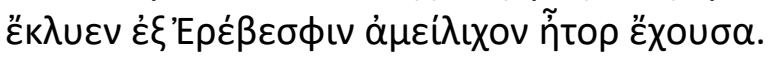

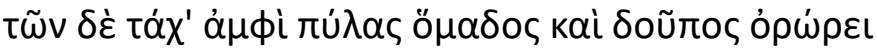

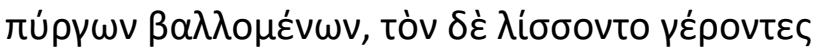




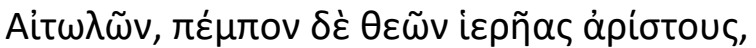

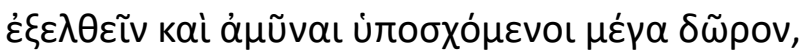

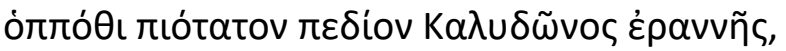

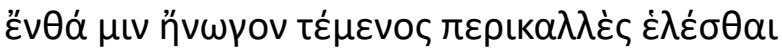

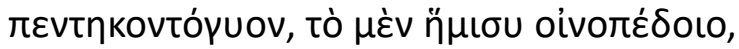

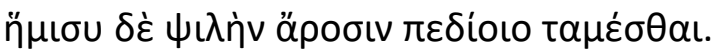

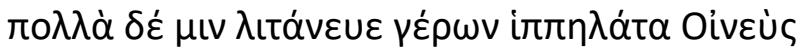

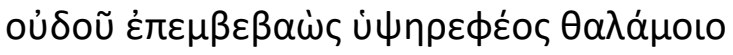

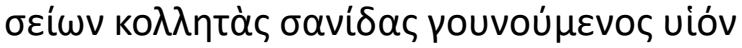

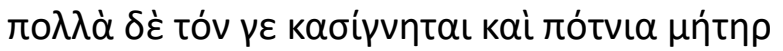

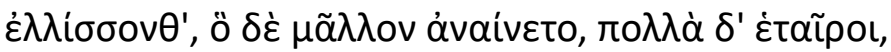

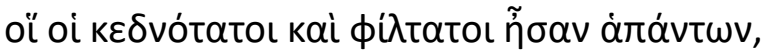

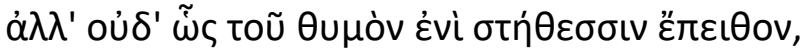

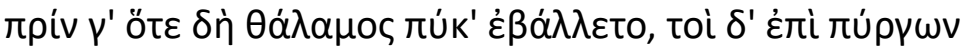

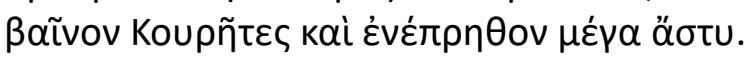

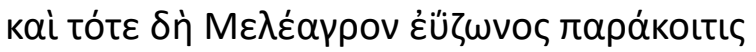

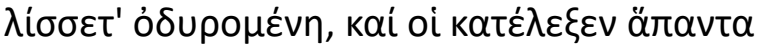

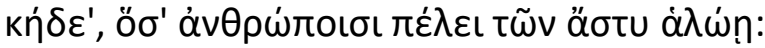

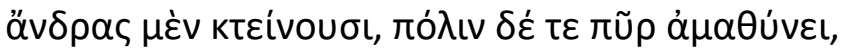

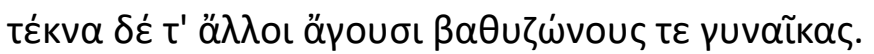

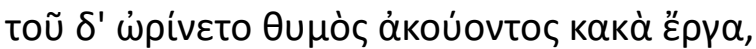

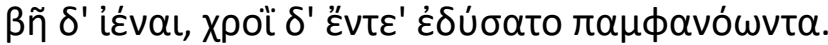

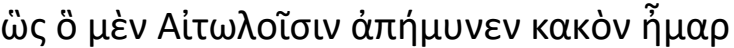

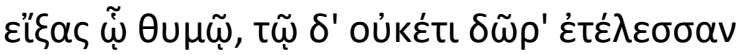

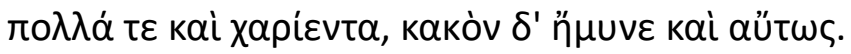

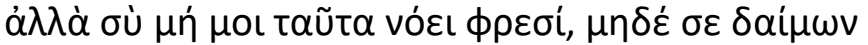

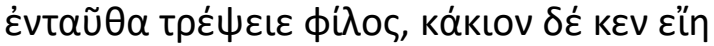

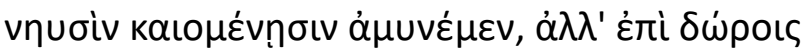

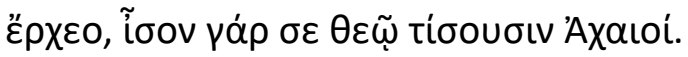

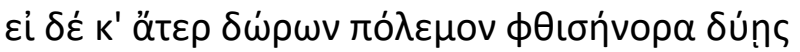

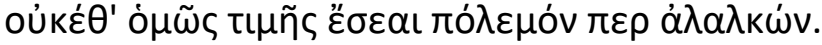

Deste modo ouvimos falar da fama dos homens heroicos de antanho, quando a algum sobrevinha a cólera furiosa: eram permeáveis a presentes e deixava-se inflectir pelas palavras. Eu próprio me recordo deste feito de há muito (recente não é de forma alguma!), como foi: a vós, todos amigos, narrarei. Combatiam os Curetes e os Etólios tenazes no combate em torno da cidade de Cálidon e entre eles se chacinavam: os Etólios por seu lado, defendiam a agradável Cálidon; mas os Curetes tentavam arrasá-la na labutação da refrega. Pois um flagelo entre eles lançara Ártemis do trono dourado, encolerizada porque Eneu não Ihe oferecera as primícias de seu pomar abundante, embora os outros deuses participassem 
da hecatombe: só à filha do grande Zeus ele não ofereceu, ou porque esqueceu ou porque não se apercebeu: é que no espírito estava grandemente iludido. Mas a arqueira, filha de Zeus encolerizada, enviou-Ihe um temível javali selvagem de brancas presas, que a seu modo causou muitos males no pomar de Eneu. Muitas altas árvores arrancou e atirou ao chão, com as próprias raízes e com as próprias flores da maçã. Porém Meleagro, filho de Eneu, matou o javali, depois que reunira de muitas cidades homens caçadores e cães: pois não por poucos homens seria domado o javali, tal era o seu tamanho; e a muitos atirou para a pira funerária. Mas a deusa levantou em torno dele alta grita e alarido (em torno da cabeça e da pele hirsuta do javali), entre os Curetes e os magnânimos Etólios. Ora enquanto combatia Meleagro, dileto de Ares tudo corria mal aos Curetes, nem podiam estar fora das muralhas, numerosos embora fossem. Mas quando de Meleagro se apoderou a ira (que faz com que no peito dos outros inche o espírito, sensatos embora sejam), foi então que irado no coração contra a mãe amada, Altaia, ele se deitou junto da esposa legítima, a bela Cleópatra, (filha de Marpessa dos belos tornozelos, filha de Eveno, e de Idas, que era o mais forte dos homens que então habitavam a terra - ele que tomara o arco para enfrentar o soberano Febo Apolo, por causa da donzela de belos tornozelos. Ela a quem no palácio o pai e a mãe veneranda chamavam pelo nome Alcíone, porque a própria mãe, num desgosto como o do alcíone muito sofrido a lamentava, porque Ihe arrebatara a filha, Febo Apolo, que atua longe). Junto dela se deitou Meleagro em ira amarga, furioso devido as imprecações da mãe, que rezava aos deuses em grande sofrimento por causa do assassínio do irmão; e com as mãos muito batia na terra que tudo alimenta, chamando por Hades e pela temível Perséfone, enquanto estava ajoelhada com o peito umedecido de lágrimas, para que eles dessem a morte a seu filho. E a Erínia que na escuridão caminha ouviu-a no Érebo, ela cujo coração não tem suavidade. Depressa em torno dos portões retumbava o estrondo das muralhas ao serem alvejadas; a Meleagro suplicavam os anciãos dos Etólios e enviaram-lhe os melhores sacerdotes dos deuses, para que saísse e os socorresse, prometendo-lhe ingente oferenda. Lá onde se estendia a mais fértil planície da agradável Cálidon: foi ai que lhe pediram que escolhesse um lindíssimo terreno de cinquenta jeiras - metade dele plantado de vinhas, a outra 
de terra arável - para que da planície fosse destacado.

Muitas súplicas lhe dirigiu o velho cavaleiro Eneu, tendo pisado a soleira de seus altos aposentos:

agitando as portas bem ajustadas, ajoelhou-se perante o filho.

Muitas súplicas Ihe dirigiam as irmãs e a excelsa mãe.

Mas ele recusava com mais afinco. Muito suplicaram

os companheiros que lhe eram mais fiéis e mais queridos.

Mas nem assim conseguiram persuadir o coração no seu peito, até que o tálamo estava a ser arrombado e os Curetes trepavam pelas muralhas e lançavam fogo à grande cidadela.

Foi então que a esposa de bela cintura de Meleagro

Ihe dirigiu súplicas, chorosas, e enumerou-lhe todos os males, que sobrevêm àqueles cuja cidade é tomada:

chacinam os homens, o fogo destrói a cidade, e estranhos levam as crianças e as mulheres de cintura firme. Moveu-se-lhe o espírito ao ouvir falar destes atos malévolos; Pôs-se a caminho e sobre o corpo vestiu suas armas resplandecentes. Assim afastou dos Etólios o dia da desgraça, cedendo a seu ânimo; mas a ele jamais pagaram os dons, muitos e preciosos. Mesmo assim ele afastou o mal. Quanto a ti, não me remoas tais coisas no espírito, ó amigo, e que a divindade por aí não te deixe enveredar! Mais difícil seria salvar as naus em chamas. Vem antes ao encontro das oferendas! E como se fosses um deus te honrarão os Aqueus. Mas se sem oferendas entrares na batalha aniquiladora de homens, não serás tão honrado, ainda que nos protejas da guerra.

Nesta narrativa de saque iminente o primeiro elemento mecionado são os portões: "depressa em torno dos portões retumbava o estrondo/ das muralhas ao serem alvejadas",

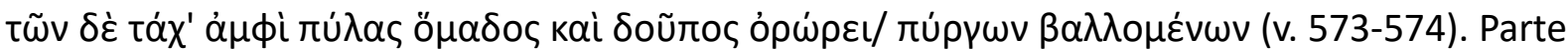
da expressão formular que descreve o elemento sonoro da cena não costuma aparecer em contextos de batalha; ela descreve o som de alguém que se aproxima e acaba por acordar

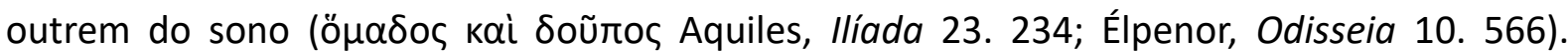

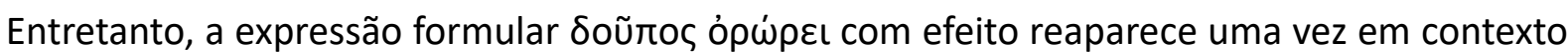
semelhante no poema, no episódio da chamada $\tau \varepsilon\llcorner\chi o \mu \alpha \chi i \alpha$, "combate pelas muralhas" em

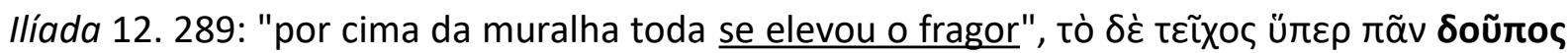

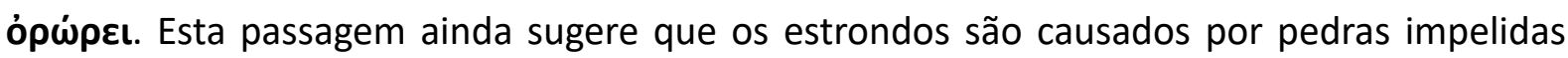
pelos inimigos contra as fortificações da muralha. É assim exatamente que a muralha erguida 
pelos aqueus ao redor do acampamento é rompida por Sarpédon e Heitor $\left({ }^{148}\right)$. O ataque de Sarpédon no lado direito da fortificação chama a atenção de Ájax, que abandona sua posição para ajudar na defesa daquele local, dando oportunidade para a realização de um ataque bems ucedido da parte de Heitor. O troiano ergue uma pedra tão grande que "dois homens, os mais fortes da comunidade não a levantariam/ facilmente com uma alavanca para o alto

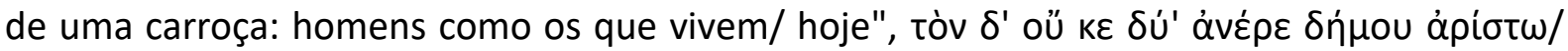

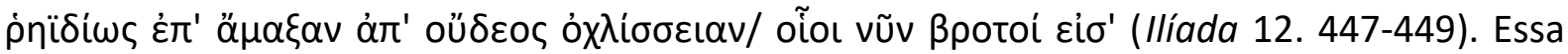
pedra é arremessada e desmantela os portões por completo. Assim, os troianos rompem as defesas do exército aqueu e invadem o espaço ocupado pelas tendas e pelas naus: "Logo uns escalaram o muro/ e outros entraram pelo portão bem construído/ os Dânaos fugiram..."

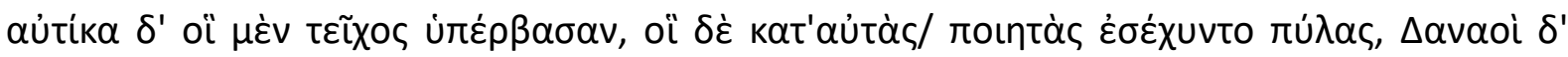

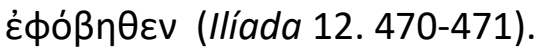

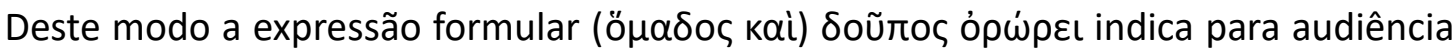
escolada no idioma tradicional dos poemas homéricos o risco iminente e a possibilidade de que a qualquer momento os portões se rompam sobre um arremesso como o de Heitor em Iliada 12. No relato de Fênix o som dos golpes de pedras que ameaçam a muralha de Cálidon são concomitantes com as visitas dos habitantes desesperados aos aposentos de Meleagro, nos versos 575-587. Esta seção termina com o verso "mais nem assim conseguiram persuadir

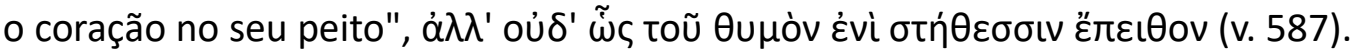

Enfim o combate também chega aos aposentos de Meleagro: "o tálamo estava a ser arrombado e os Curetes trepavam/ pelas muralhas e lançavam fogo à grande cidadela", $\pi \rho i ́ v$

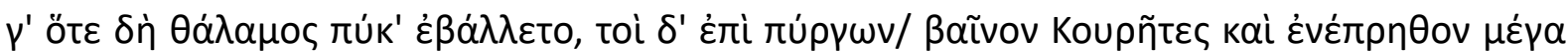

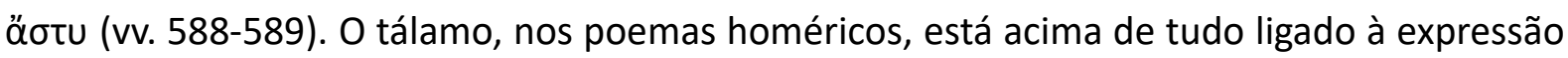
da intimidade - sobretudo das mulheres, onde passam mais tempo (llíada 3. 142; 3. 174; 6. 336; Odisseia 4. 121; 17. 36) - e do casamento (Odisseia 4. 263; 23. 192). Por isso, o cômodo é contrastado com a guerra, às vezes ironicamente "encontrou [Alexandre] no tálamo a tratar

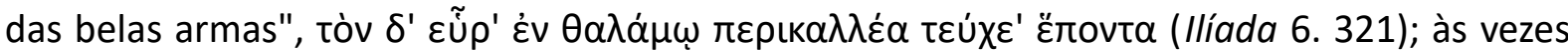

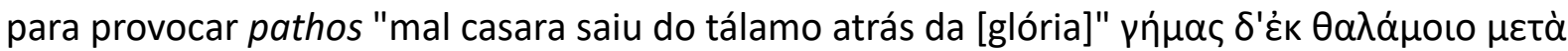

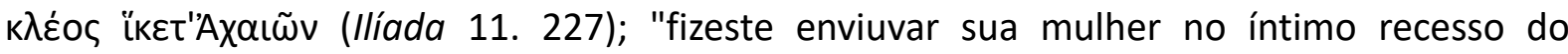




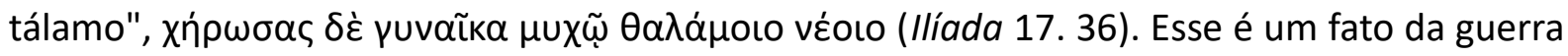
e a llíada costuma enfatizá-lo com frequência nas imagens que retratam maridos e esposas: a guerra enviuva as mulheres e destrói os lares.

O combate muito próximo da muralha também é percebido como grande risco para a cidade em outras passagens da llíada, especialmente no contexto da aristeia. Quando, por exemplo, Pátroclo se aproxima da muralha, Apolo intervém, cuidando para que a cidade não seja capturada antes da hora: "três vezes pisou Pátroclo um canto sublime da muralha/ três

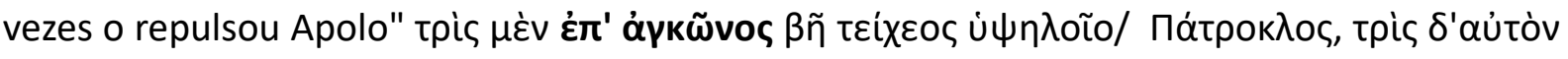

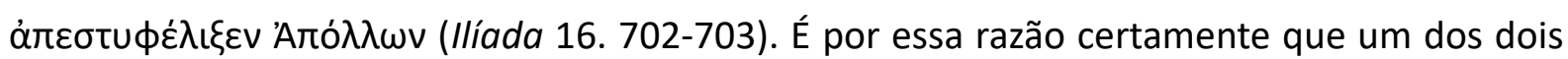

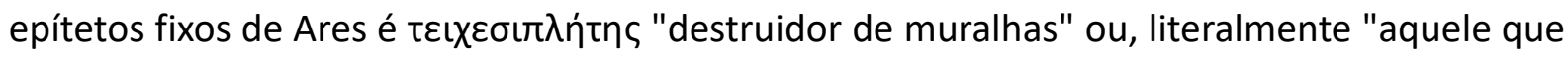
se aproxima/aborda a muralha" (Ilíada 5. 31, 5. 455); o epíteto do deus é composto pelas

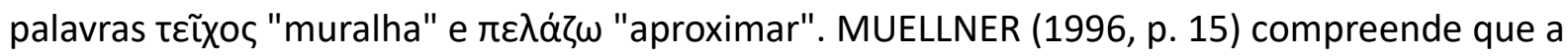
aproximação é uma espécie de metáfora: "aproximar-se de uma muralha é uma metáfora adequada para a propensão que esse deus mostra em beirar os limites do comportamento, bem como para a propensão semelhante e perigosa que os grandes heróis mostram em beirar os limites entre a mortalidade e a divindade", ("approaching a wall is an appropriate metaphor for that god's tendency of reaching the limits of behavior as well as the great heroes' similar and dangerous tendency to rich the limits between mortality and divinity") $\left({ }^{149}\right)$. Poderíamos acrescentar também que, dadas as condições, a referencialidade tradicional da aproximação de uma muralha é a sua provável e iminente captura pelas mãos do herói que se aproxima.

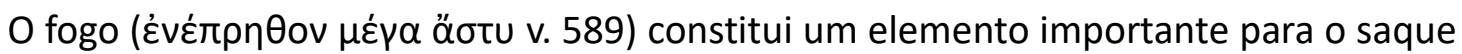
de cidades e está relacionado principalmente à ideia de ameaça às muralhas $\left({ }^{150}\right)$. O fogo

149 MUELLNER (1995, p.15)

150 Ver NAGY (2005, pp. 81-84) que vê referências à destruição do mundo pela conflagração total e pelo dilúvio nas menções ao fogo e à agua na Ilíada: "in the Iliad, the fire of the Achaeans that is destined to destroy the Trojans and, conversely, the fire of the Trojans that threatens to destroy the Achaeans are both pervasively compared to a cosmic fire of Zeus, wich threatens to destroy the whole world. In Iliad 12.17-33, on the other hand, where it is prophesied that the rivers of the Trojan plain will erase all traces of the Achaean Wall at Troy, the flooding of the plain is described in language that evokes a cosmic cataclysm ("na Ilíada o fogo dos Aqueus que está destinado a destruir os Troianos e, inversamente, o fogo dos Troianos que ameaça destruir os Aqueus, são ambos generalizadamente comparados ao fogo cósmico de Zeus, que ameaça destruir todo o mundo. Em llíada 12.17-33, por outro lado, onde é profetizado que os rios da planície troiana vão apagar os traços da Muralha Aqueia em Troia, a enchente na planície é descrita em uma linguagem que evoca um cataclismo cósmico"). 
representa uma enorme ameça para o acampamento aqueu no decorrer do "combate pelas

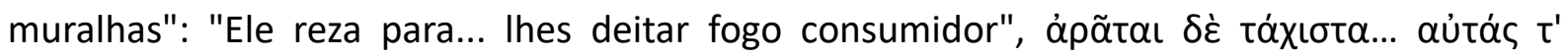

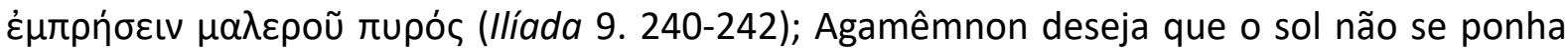
antes que ele destrua "a sala de banquetes de Príamo/ negra de fumo e... as portas com fogo

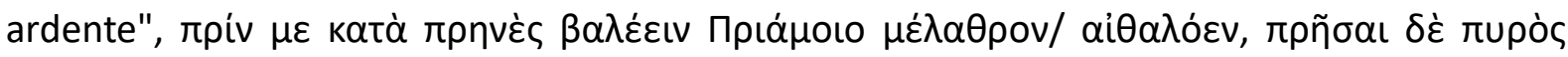

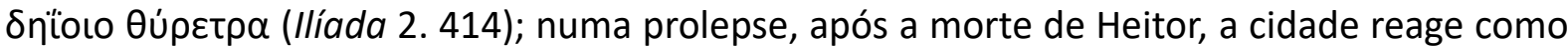

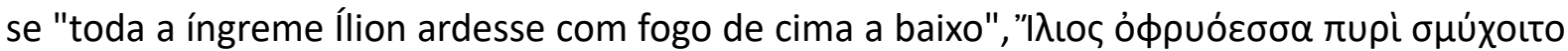

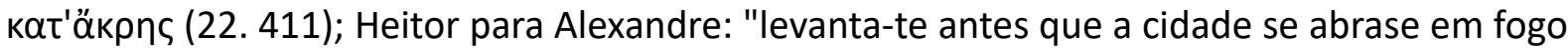

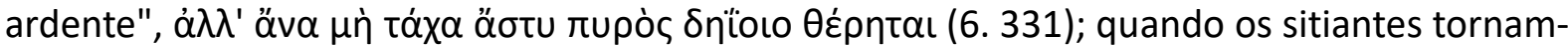
se agora os sitiados: "[Heitor] teria queimado com fogo ardente as naus niveladas" kaí vú k'

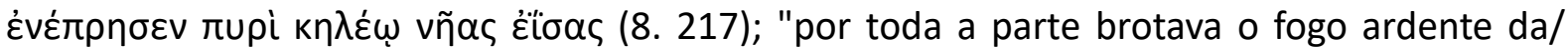

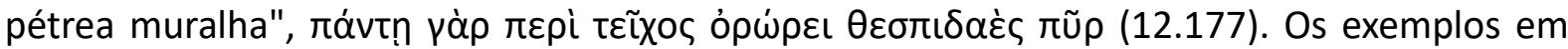
sua maioria expressam o temor do incêndio ou o desejo de lançá-lo à cidade (ou aos navios). Raramente vemos o fogo queimar, tal como no relato de Fênix, mas ainda aqui a cidade consegue permanecer de pé.

Da mesma forma que Aquiles, Meleagro responde sempre às promessas de maiores honrarias da comunidade e às súplicas dos familiares e dos amigos mais íntimos com recusas até o momento em que Cleópatra: "Ihe dirigiu súplicas, chorosas, e enumerou-Ihe todos os

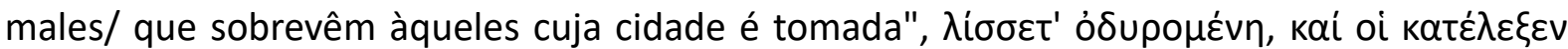

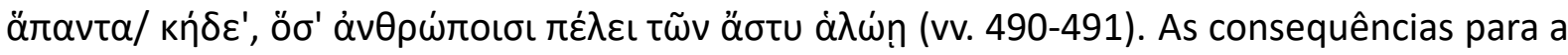
população da cidade são regulares: população masculina é exterminada, mulheres e crianças são escravizadas (quando as crianças não são assassinadas em massa) e a cidade é destruída

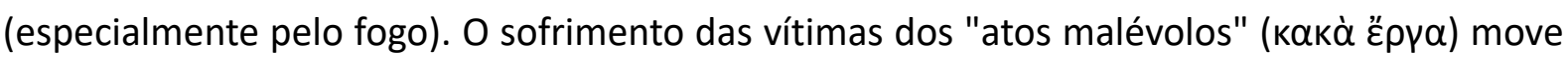
Meleagro, que decide retornar ao combate. Por muito pouco o herói consegue afastar o dia da destruição da cidade de Cálidon, "assim afastou dos Etólios o dia da desgraça", Aitw

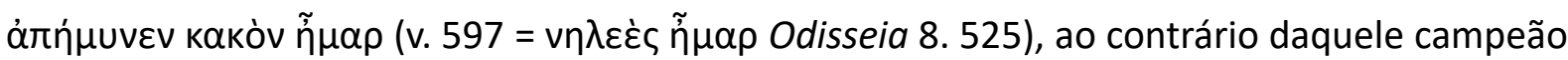
e marido presente no símile da Odisseia.

\subsection{A CIDADE NO ESCUDO}


A passagem que estudaremos a seguir encontra-se no final de llíada 18. Após a morte de Pátroclo, um longo e dramático combate se desenrola ao redor do seu cadáver até que Menelau e Meríones, auxiliados por ambos Ajantes o recuperam e carregam para as tendas e navios no acampamento aqueu. Heitor, todavia, apropria-se do armamento de Aquiles, que Pátroclo envergava, criando a necessidade da fabricação de novas armas (Ilíada 18. 130-137). Tétis imediatamente se dispõe a ajudar e viaja até a casa de Hefesto. Esta cena é organizada, como de costume, segundo as regras da cena-padrão de hospitalidade: (1) o visitante chega ao local de destino e espera à porta (vv. 369-370); (2) encontra quem procura, o qual recebe uma descrição (vv. 371-380): Hefesto está atarefado com seus foles e forja; (3) o visitante é notado (vv. 382-387): Cáris percebe a chegada de Tétis e a conduz para dentro de casa; (4) serve-se comida e bebida: o narrador adapta esta unidade com uma conversa entre Cáris e Hefesto, cujo objetivo é destacar o prestígio de Tétis, e uma nova descrição dos trabalhos e objetos de Hefesto (vv. 391-421). (5) Entabula-se conversação (vv. 422-467): Tétis aproveita este momento para desabafar. Ela conta que não queria ter casado com Peleu, que Apolo tirou a vida de Pátroclo. Ela reconta o que sucedeu a Aquiles desde o começo, passando pela embaixada e pelo apresamento da armadura por Heitor. O tema da desavença entra Aquiles e Agamêmnon vai dando lugar ao tema da vingança a partir deste ponto. A deusa, então, pede pela fabricação de uma nova armadura e Hefesto consente $\left({ }^{151}\right)$.

A descrição da elaboração de novas armas vai se concentrar no escudo. O narrador se lança agora na maior amplificação do poema: um microcosmo da experiência humana $\left({ }^{152}\right)$. Nisto o novo escudo forjado para Aquiles difere muito dos demais. No escudo de Agamêmnon (Ilíada 11. 32-37), no cinturão e escudo de Héracles (Odisseia 11. 609-616; Escudo 264-270), bem como na égide de Atena (Ilíada 5. 736-742), encontramos monstros apavorantes, serpentes, cenas de batalha e assassinatos, cujo intenção é apotropaica. No escudo de Aquiles, muito pelo contrário, a maior parte das cenas representadas descrevem momentos pacíficos da vida cotidiana e até mesmo cenas alegres $\left({ }^{153}\right)$.

De acordo com o estudo de TAPLIN (1980, p. 5-11) o escudo possui cinco círculos ou bordas concêntricas, como um "alvo para flechas" $\left({ }^{154}\right)$. O narrador descreve o seu conteúdo

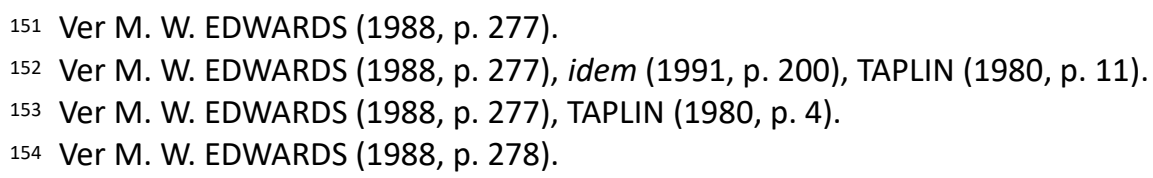


de dentro para fora: no primeiro encontramos a representação (1) da terra, das estrelas e do mar (llíada 18. 483-489); no segundo, (2) a vida urbana, com um contraste entre a cidade em tempos de paz e a cidade em guerra (vv. 490-540); no terceiro círculo está representada (3) a vida rural, organizada pelas estações do ano (vv, 541-589); (4) a cena de dança (vv. 590-606); e finalmente (5) o oceano (vv. 606-607).

Transcrevo abaixo a passagem que interessa ao presente trabalho, a representação da cidade sitiada em llíada 18. 508-540:

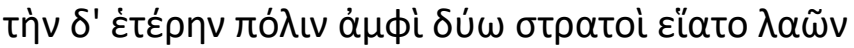

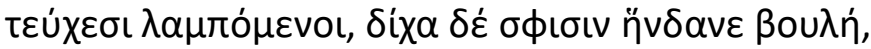

$510 \quad$ ทे

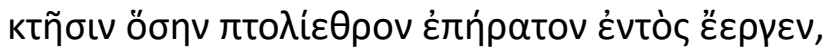

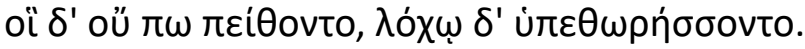

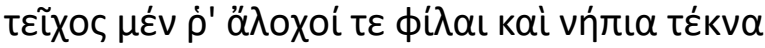

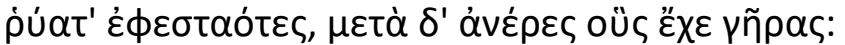

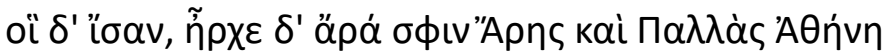

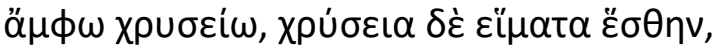

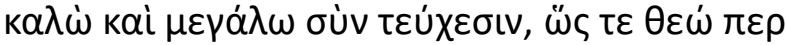

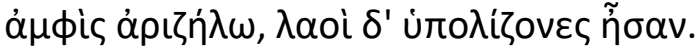

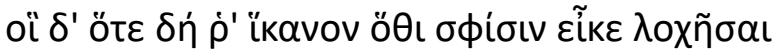

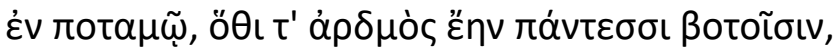

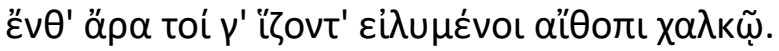

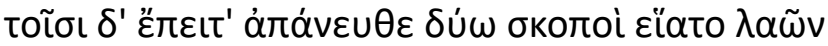

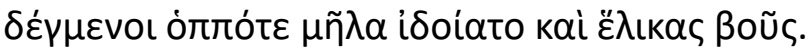

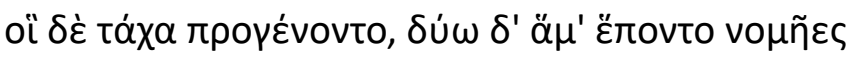

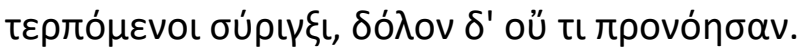

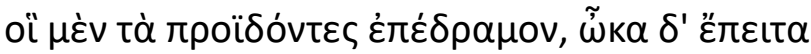

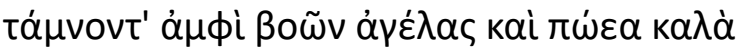

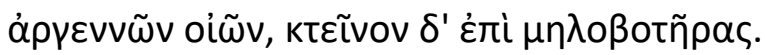

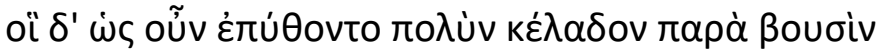

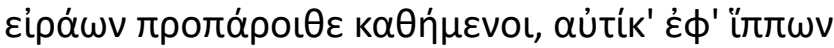

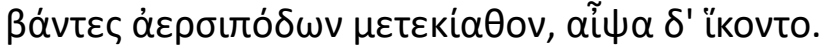

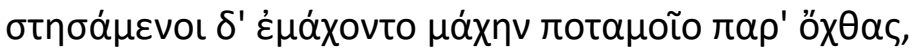

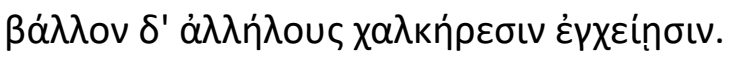

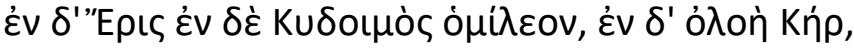

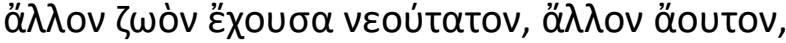

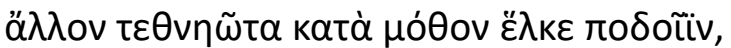

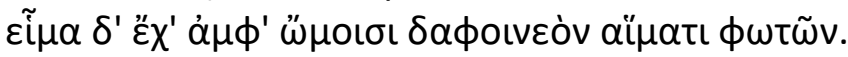

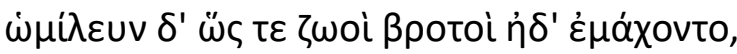

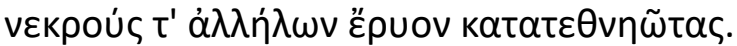


Mas por volta da outra cidade estavam dois exércitos, refulgentes de armas. Duas alternativas Ihes aprouveram: ou destruir a cidade, ou então dividir tudo em dois, todo o patrimônio que continha a cidade aprazível. Os sitiados não queriam e armavam-se para uma emboscada. As esposas amadas e as crianças pequenas guardavam em pé a muralha, e com elas os homens já idosos. Os outros saíam, liderados por Ares e Palas Atena, ambos de ouro e de ouro revestidos, belos e altos nas suas armas, como deuses que eram, salientes no meio dos outros; os homens eram menores.

520 Quando chegaram aonde lhes pareceu fácil a emboscada, num rio que servia de bebedouro para todos os rebanhos, aí se posicionaram, revestidos de fulvo bronze. Depois saíram dois vigias para longe da hoste, à espera de verem chegar as ovelhas e bois de chifres recurvos, que chegaram depressa. Atrás deles seguiam dois pastores, deleitando-se ao som da flauta. Não pressentiram o dolo. Ao verem-nos contra eles se atiraram os soldados e depressa cotaram o acesso às manadas de bois e aos belos rebanhos de ovelhas brancas e em seguida mataram os pastores. Mas os sitiadores ouviram a grande confusão dos bois, sentados à frente dos lugares da assembleia, e logo montaram nos seus cavalos de patas leves e chegaram depressa. Posicionando-se, combateram junto das correntes do rio, e arremeteram uns contra os outros com lanças de bronze. Com eles estava a Discórida, o Tumulto e o Destino fatal que agarrava num homem vivo e recém-atingido e noutro incólume; e a outro já morto arrastava por entre turba pelos pés. A veste que levava aos ombros estava vermelha de sangue humano. Participavam na luta e combatiam como homens vivos, e arrastavam os cadáveres dos mortos uns dos outros.

O retrato da cidade sitiada apresenta inicialmente uma descrição de dois exércitos ou talvez dois batalhões de exército deliberando duas alternativas diferentes: "duas alternativas

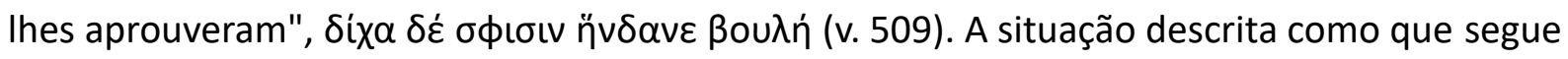
a estrutura da cena-padrão de deliberação indireta $\left({ }^{155}\right)$. Nesta cena-padrão, como notamos, a primeira alternativa costuma ser uma resposta emocional ou instintiva às circunstâncias, ao passo que a segunda é racional, ponderada; no geral a segunda é escolhida pelo agente $\left({ }^{156}\right)$.

155 Ver Odisseia 10.438-446 e DE JONG (2001, p. 265).

156 Supra, p. 104. 
Embora nenhuma das narrativas estudadas neste trabalho, com a exceção desta, apresentem uma descrição semelhante para um exército, a narrativa indireta da canção de Demódoco em Odisseia 8 mostra a população troiana em situação parecida, ponderando o que fazer com o cavalo de madeira. Os troianos escolhem a terceira e última alternativa: "três planos lhes agradaram/ ... ou deixá-lo ficar como oferenda encantadora para os deuses/ e foi isto o que

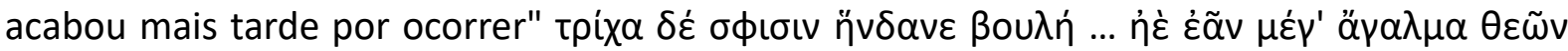

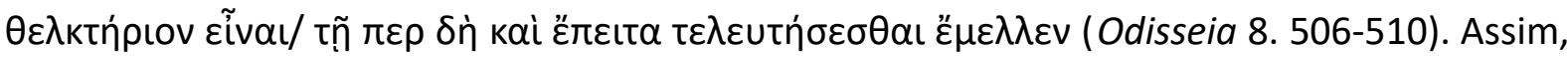
de acordo com a diç̧ão tradicional do epos arcaico, a possibilidade de que o exército escolha a primeira alternativa é maior, porque mais comum, todavia, além de escolha pela primeira alternativa, aquela que é mais emotiva, ser possível (por exemplo, Odisseia 10. 438-446), não é incomum, na Odisseia, que um personagem não tome nenhuma decisão (DE JONG, 2001, p. 96).

Quanto ao conteúdo da deliberação, à primeira vista, o exército parece decidir entre a destruição total cidade ou apenas a sua captura e divisão dos despojos. Essa concepção seria absolutamente original, uma vez que não há, até onde conferimos, sinal de uma distinção deste gênero no emprego do vocabulário. EDWARDS (1991, p. 219) sugere que esta cena de deliberação é baseada em Ilíada 22. 111-121 em que Heitor pondera entregar Helena e dividir com os aqueus as riquezas de Troia. O problema desta interpretação é que ela ignora o fato de que as tentativas de negociação geralmente partem dos sitiados, não dos sitiantes (Menelau Ilíada 3. 70; Antenor llíada 7. 350; Heitor Ilíada 22. 111-121). Entender esta cena como a descrição de preparativos de uma missão diplomática ou a discussão posterior à uma missão nesses termos poderia talvez conciliar essas visões. Nos poemas homéricos, somente neste contexto, o exército sitiante procura negociar com os residentes de uma cidade sitiada

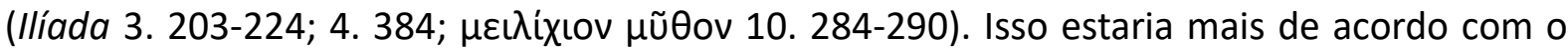
que observamos na llíada e em outras tradições de poesia épica: os sitiados, em um primeiro momento, também respondem à negociação com arrogância.

Em seguida, encontramos uma cena frequente, semelhante à "vista desde a muralha"

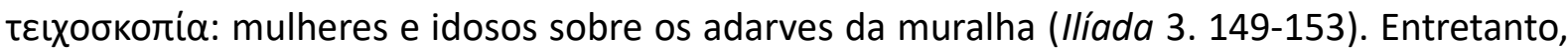

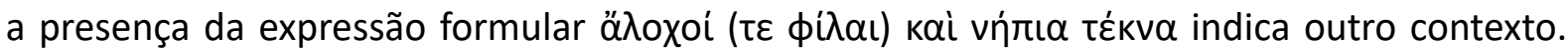
Como demonstrou WERNER (2008) a expressão "esposas e crianças pequenas" na linguagem 
especial de homero está profundamente relacionada ao saque de cidades e designa regular e especialmente "o grupo de vítimas reais ou pontenciais de guerra". Assim, esta expressão é usada de forma a evocar as consequência do cerco de uma cidade para os seus habitantes: o assassinato da população masculina e a escravização de mulheres e crianças. Ao evocar essas consequências o poema associa a presente cena a tantas outras já mencionadas e analisadas neste trabalho como, por exemplo, o relato de Briseida sobre o cerco de Lirnesso:"vi [meu

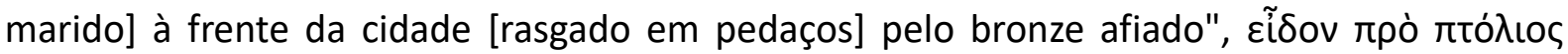

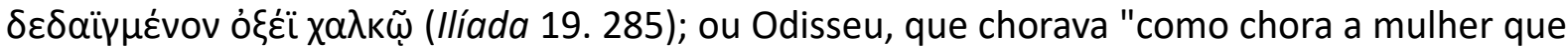

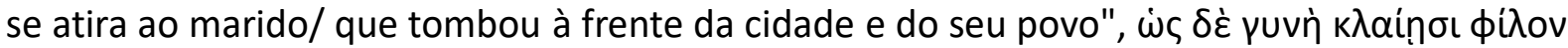

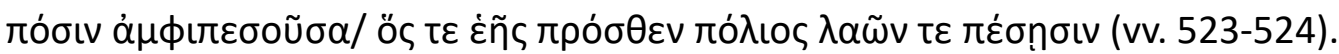

Desse passo em diante encontramos a representação de um confronto. Os habitantes da cidade sob o cerco do exército, por recusarem as tentativas de negociação, decidem fazer uma emboscada, que toma a forma, recorrente na llíada, de uma razia de gado. Entretanto, o ataque acaba fracassando porque o som dos animais de rebanho assustados interrompe a assembleia dos sitiantes, que montam em seus cavalos para atacar os inimigos.

Este trecho foi examinado por VIEIRA (2016, p. 78-101), que encontrou as seguintes características marcantes: (1) dicção tradicional associada ao ambiente campestre e às outras conexões temáticas do tema da razia de gado; (2) a representação do ataque surpresa como um evento paralelo ou justaposto ao ataque à cidade (características em comum com o cerco a Tebas-sob-Placo, Lirnesso e Pédaso); (3) o ataque ao rebanho não acontece antes do cerco, nem antes da batalha campal entre os exércitos, mas acontece entre ambos os eventos; (4) o ataque não envolve um grupo pequeno comandado por um líder, mas todos os soldados da

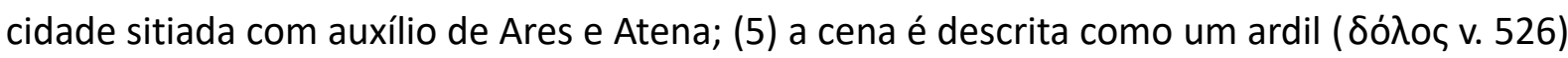
e uma emboscada ( $\lambda$ óxos v. 513) (VIEIRA, 2016, pp. 82-83).

\subsection{TEBAS -SOB-PLACO}

Esta passagem encontra-se em um cena famosa e importante da llíada. Trata-se do encontro entre Heitor e Andrômaca diante das Portas Esqueias (Ilíada 6. 369-529). Esta cena está, por sua vez, inserida em um contexto mais amplo de visitas: os encontros de Heitor 
com Hécuba, com Helena (Ilíada 6. 312-368) e mulheres ordinárias da cidade troiana. O foco da narrativa se volta para a figura de Heitor, para os sentimentos e preocupações das filhas e esposas dos troianos enquanto os seus maridos se encontram em combate $\left({ }^{157}\right)$. Ilíada 6 nos apresenta um mundo dividido $\left({ }^{158}\right)$ : os sentimentos, valores e prioridades dos homens e das mulheres troianos são diferentes e esta diferença chega ao paroxismo no encontro de Heitor e Andrômaca nas Portas Esqueias. Andrômaca veio acompanhada da criada e do pequeno Astíanax e enquanto o marido contempla o filho, a esposa tenta convecer o marido a deixar a batalha e permanecer na segurança da muralha. As cenas envolvendo maridos e esposas são particularmente importantes para este tema. O núcleo familiar, do ponto de vista do tema do cerco a cidades, não é retratado, como é na Odisseia, pela ótica da harmonia (6. 183-186) ou da fidelidade (11. 429-430) $\left({ }^{159}\right)$, mas como um laço que pode ser ou será destruído devido à guerra e às obrigações do marido como cidadão e membro da polis, como contraste entre protetor e protegido, entre coragem masculina e desamparo feminino.

Vejamos agora a cena em que a destruição de Tebas-sob-Placo é vista praticamente da perspectiva de um dos sitiados, em llíada 6.405-434:

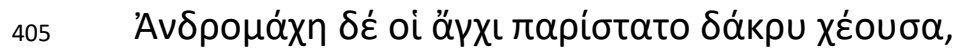

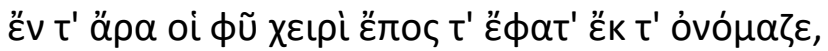

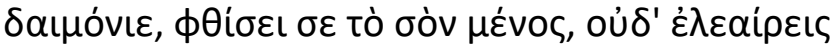

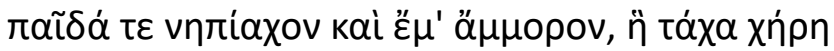

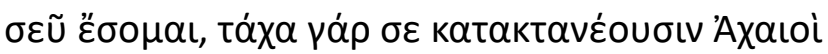

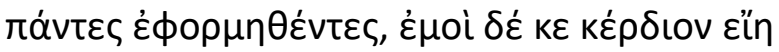

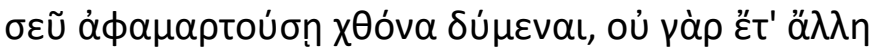

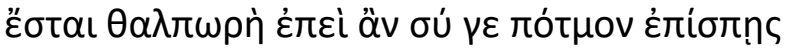

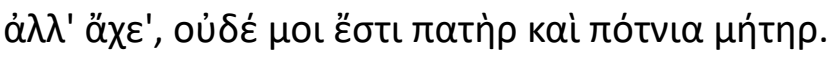

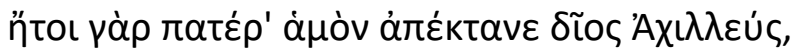

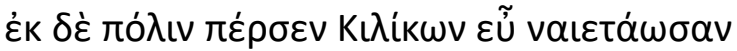

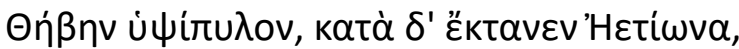

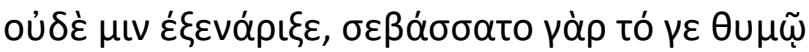

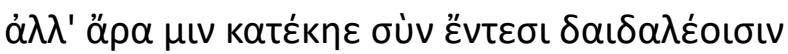

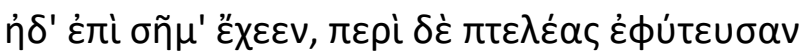

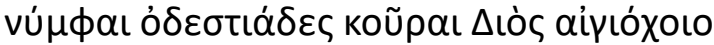

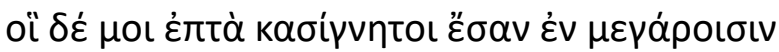

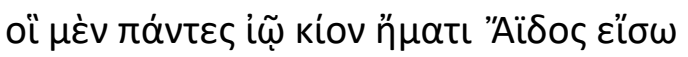

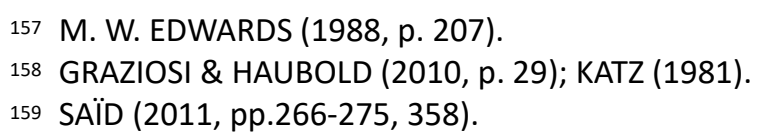




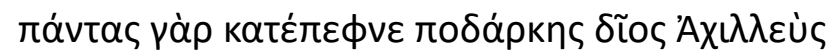

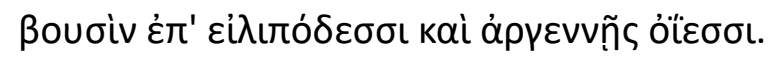

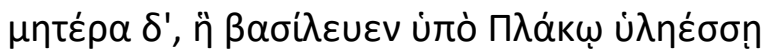

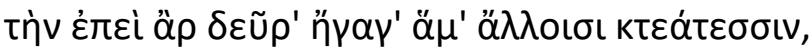

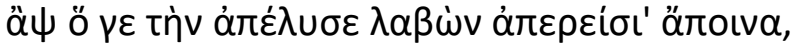

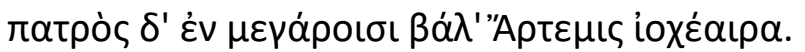

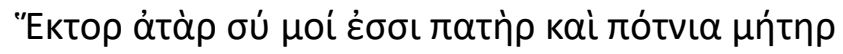

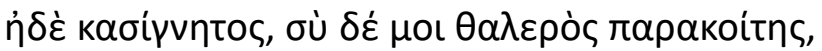

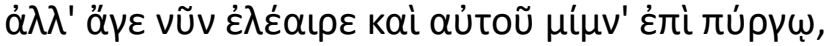

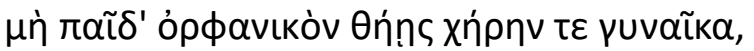

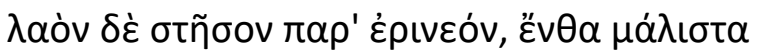

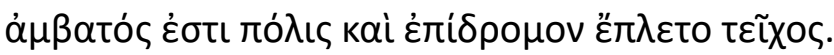

Mas Andrômaca aproximou-se dele com lágrimas nos olhos e, acariciando-o com a mão, chamou-lhe pelo nome: 'Homem maravilhoso, é a tua coragem que te matará! Nem te compadeces desta criança pequena nem de mim, desafortunada, que depressa serei a tua viúva. Pois rapidamente todos os Aqueus se lançarão contra ti e te matarão. Mas para mim seria melhor descer para debaixo da terra, se de ti ficar privada. Nunca para mim haverá outra consolação, quando tu encontrares o teu destino, mas só sofrimentos. Já não tenho pai nem excelsa mãe: meu pai foi morto pelo divino Aquiles, que arrasou a cidadela bem habitada dos Cilícios, Tebas de altos portões. Assassinou Eécion, porém não o despojou das armas, por respeito ao seu espírito; mas cremou-o vestido com a rica armadura, e por cima fez um túmulo: ao redor plantaram ulmeiros as ninfas da montanha, filhas de Zeus detentor da égide. Quanto aos sete irmãos que eu tinha no palácio, todos eles num só dia desceram à mansão de Hades: matou-os a todos o divino Aquiles de pés velozes, no meio do gado de passo cambaleante e das brancas ovelhas. E minha mãe, que foi rainha debaixo da arborizada Placo, para cá ele a trouxe com o resto dos despojos, mas depois libertou-a tendo recebido incontável resgate; no palácio de seu pai foi abatida por Ártemis, a arqueira. Heitor, tu para mim és pai e excelsa mãe; és irmão e és para mim o vigoroso companheiro do meu leito. Mas agora compadece-te e fica aqui na muralha, Para não fazeres órfão o teu filho e viúva a tua mulher. Quanto à hoste, posiciona-a perto da oliveira brava, donde a cidade pode ser melhor escalada e a muralha está 
exposta ao assalto...

Em termos formais, a fala de Andrômaca combina dois padrões preponderantes de discurso tradicional: a reprovação (Ilíada 6. 407-410; 431-432) e o lamento fúnebre (llíada 6. 410-431) $\left({ }^{160}\right)$. Por isso, a fala principia com uma crítica à coragem de Heitor: "a tua coragem

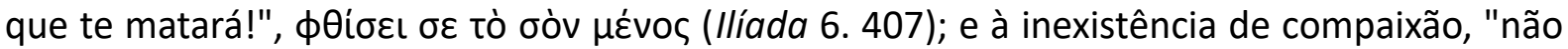

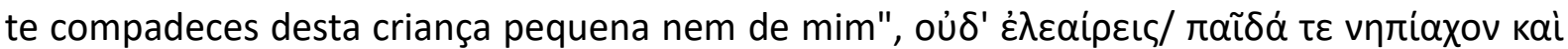

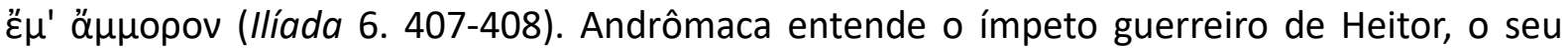
$\mu \varepsilon ́ v o \varsigma$, ou a sua coragem, como um vício que o levará à morte: "pois rapidamente... os

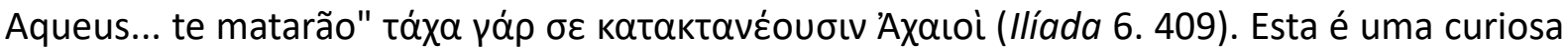
inversão. Pois, nos discursos de censura homéricos encontramos, como regra, a reprovação da indiferença do soldado para o combate ou às vezes a sua completa recusa. Em Ilíada 3. 30-57, exempli gratia, Alexandre se depara com Menelau em campo de batalha. Ao ver o

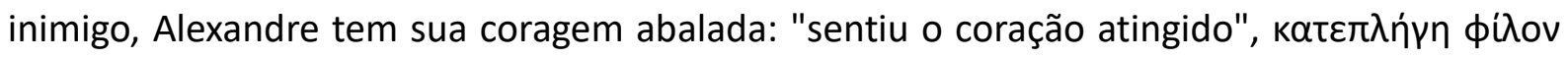
ท̃ंop (Ilíada 3. 31); e retrocede para o meio das tropas amigas: "se imiscuiu no meio do seu

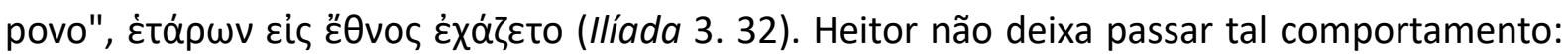

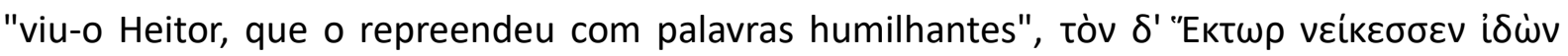

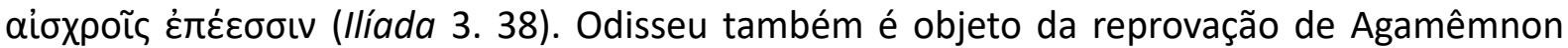
em Ilíada 4. 329-348, não por recuar covardemente, como Alexandre, mas por aparentar remissão. Odisseu e o seu exército ficam parados: "pois a hoste não tinha ouvido o grito de

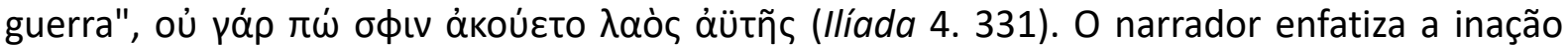

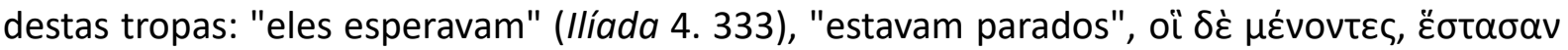
(Ilíada 4. 334) - em outros momentos utiliza-se, por exemplo, a expressão ő

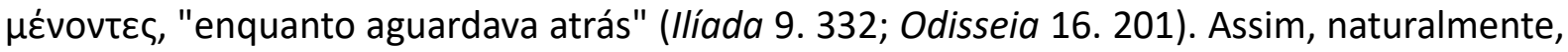
Odisseu e suas tropas provocam a reprovação de Agamêmnon: "quando os viu, repreendeu-

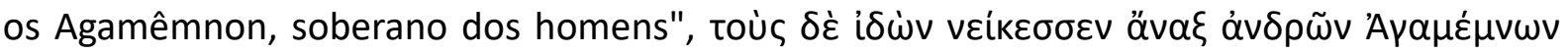
(Ilíada 4. 336). A fala de Andrômaca, na sua abertura, inverte essa concepção (GRAZIOSI \& HAUBOLD, 2010, p. 193).

A reprovação das virtudes guerreiras logo se transforma em um lamento; Andrômaca 160 Ver VIEIRA (2016, p. 49, n. 8), para a bibliografia sobre esta cena em específico. 
executa um lamento fúnebre diante do marido ainda vivo, "choravam Heitor, ainda vivo", ह̌tı

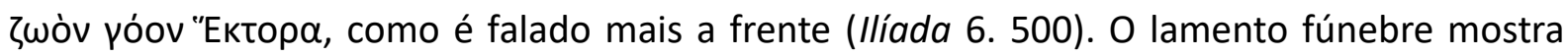
quatro segmentos principais, segundo GRAZIOSI \& HAUBOLD (2010, p. 193): uma analepse trágica do seu passado - da qual trataremos adiante - (llíada 6. 415-429); a expressão de sua dependência completa do marido (Ilíada 6. 410-412; 429-430) e o medo diante de um futuro sem o marido (llíada 6. 431-432). Este lamento fúnebre para o marido vivo também antecipa o lamento fúnebre para o marido morto em Ilíada 22. 475-515 e 24. 723-46.

A expressão de dependência do marido é o coração do lamento de Andrômaca, é a conclusão a que a lógica do relato necessariamente leva o interlocutor (e o ouvinte). Depois da admoestação inicial (Ilíada 6. 407-410), Andrômaca antecipa a morte futura de marido e o sofrimento, sem nenhuma consolação possível, que isso lhe acarretará (Ilíada 6. 410-413). A expressão máxima da dependência de Andrômaca vem depois de um analepse tripartite em que ela recorda a destruição de sua família e cidade (VIEIRA, 2016, p. 49). Heitor é tudo que restou para ela, sua única fonte de conforto e proteção.

O tema da captura de destruição de cidades se apresenta logo no início da analepse, entre dois versos que recuperam a morte de Eécion, o foco principal da narrativa: "meu pai

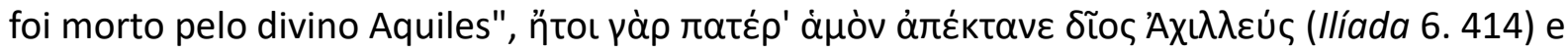

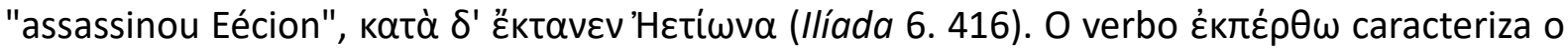

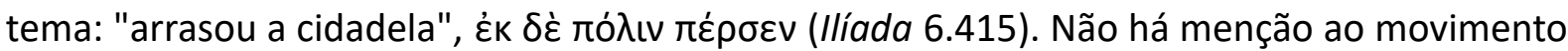
do exército em direção à cidade, como em llíada 1.366. A tão comum e econômica expressão "cidade de Eécion", recebe novos elementos: um gentílico no genitivo plural e um particípio em função de adjetivo modificado por um advérbio, "arrasou a cidadela bem habitada dos

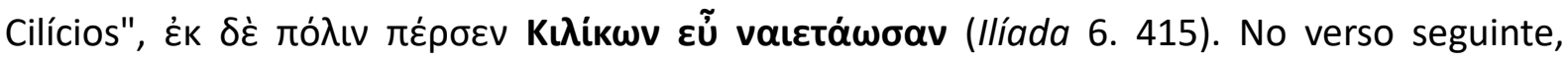
encontramos um aposto, com o nome da cidade e um epíteto tradicional: "Tebas de altos

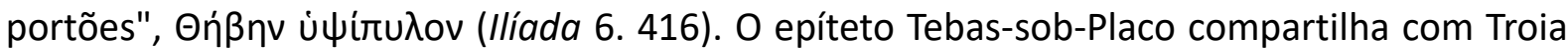

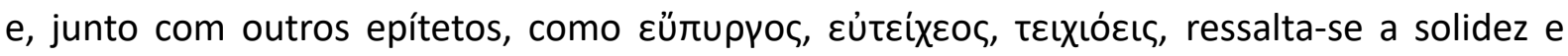

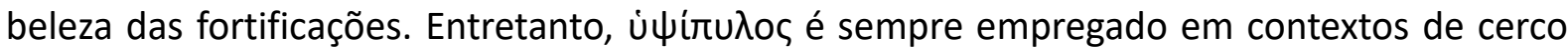
de cidade (Ilíada 6. 416) ou onde o saque é uma possibilidade iminente que é prevenida pela intervenção de uma divindade, como em Ilíada 16. 698 e $21.544\left({ }^{161}\right)$. O verso que indica 
essa possibilidade, aparece dentro da aristeia de Pátroclo, depois de uma sequência de androktasiai ou "catálogos de mortos" (16.284-351, 399-503, 569-644, 692-7); e dentro da aristeia de Aquiles, durante a retirada em massa dos soldados troianos para dentro das muralhas, assinalando este ponto crucial na narrativa, quando uma cidade corre o risco mais

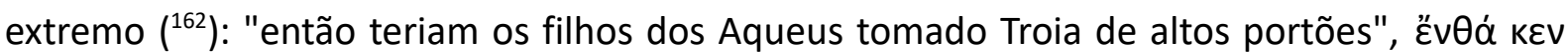

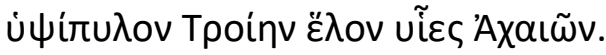

Não há menção ao contexto em que se dá a morte de Eécion. No campo de batalha, diante dos altos portões da cidade? No interior da cidadela, vencida a muralha? Ignoramos. É interessante notar que, enquanto o foco da narrativa do ponto de vista do vencedor se volta imediatamente para os despojos, no lamento de Andrômaca, a narrativa se concentra na preservação daqueles que poderiam ser despojos preciosos de guerra: "porém não o

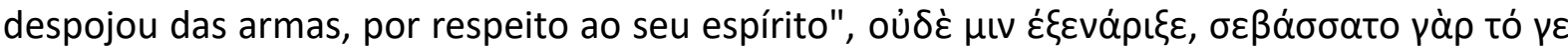

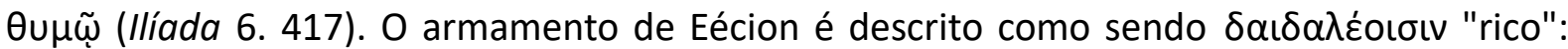

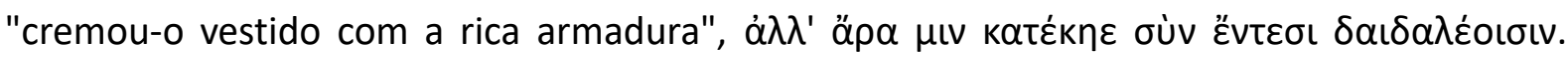
(Ilíada 6. 418). Este é o mesmo adjetivo usado para caracterizar a lira apresada por Aquiles. O tratamento dado ao cadáver de Eécion é respeitoso. O desejo de ser cremado com a armadura é também externado pelo desafortunado Elpenor em Odisseia 11. 74: "queima-me

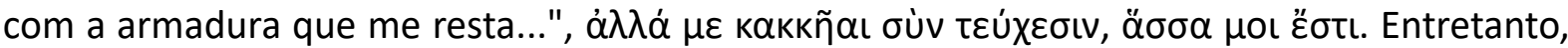
é muito mais frequente que um soldado, mesmo quando é capaz de vencer a vontade de mutilar o cadáver do seu inimigo, decida-se por recolher as armas do adversário derrotado, tal como Heitor em llíada 7. 82-6, por exemplo. KIRK (1990, p. 214) enxerga uma "profunda ironia" no cuidado que Aquiles dispensa ao cadáver de Eécion em llíada 6. 417-420 em razão daquilo que ele fará com o cadáver de Heitor mais adiante. Outros comentadores entendem que poema descreve dois Aquiles distintos: pré-cólera e pós-cólera (SCHEIN, 1984, pp. 89127).

Andrômaca menciona na sequência a chacina de sete irmãos que ela tinha no palácio real tebano: "quanto aos sete irmãos que eu tinha no palácio... matou-os a todos o divino

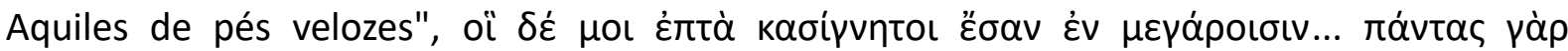

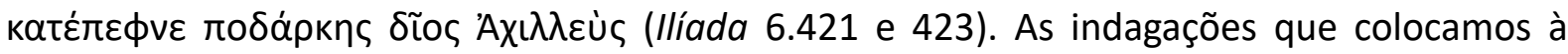

162 AUSTIN (1969), GAERTNER (2011, p. 302) e VILLA (2018, p. 73) para esta passagem, bem como androktasiai em geral. 
narrativa da morte de Eécion também valem para o aniquilamento destes sete irmãos. Esta micronarrativa nos apresenta pouquíssimos detalhes, como o fato de terem morrido todos

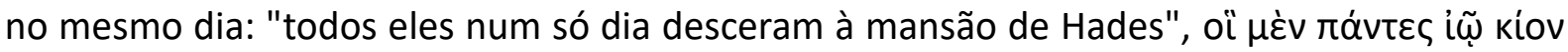

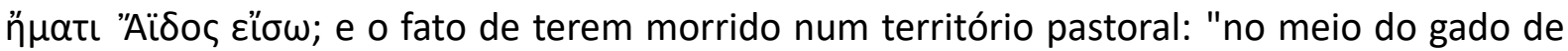

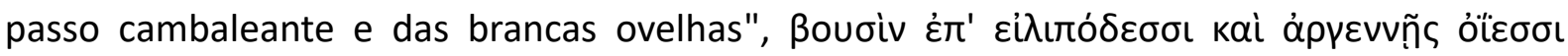
(Ilíada 6.422 e 424). Segundo VIEIRA, este microrrelato descreve um episódio de razia de gado, um ataque repentino e isolado da batalha campal diante das muralhas de Tebas-sobPlaco ou da tomada efetiva da cidade, como parece ser o caso para a morte de Eécion e a captura de sua esposa (VIEIRA, 2016, p. 50). A razia ou roubo de gado configura "situação de apropriação súbita e violenta de animais pastoris, mas também furtiva e, assim profundamente associada à capacidade ambígua da métis ou astúcia" (VIEIRA, 2016, pp. 155156).

O destino das mulheres é diverso do destino dos homens. Enquanto os sete irmãos de Andrômaca são mortos todos juntos em uma única incursão, e Eécion é morto, talvez em um combate nos arredores da muralha, como a llíada mais de uma vez apresenta como o local de maior risco para os habitantes da cidade sob cerco, ou talvez em batalha campal, a mãe de Andrômaca é escravizada e, mais tarde, libertada mediante o pagamento de um resgate, feito provavelmente por algum membro da família. Como nos trechos estudados, mulheres e bens entesouráveis são mencionados juntos. Os versos 425-426 apresentam a reviravolta de rainha à escrava que depois reaparecerá nos trágicos: "e minha mãe, que foi rainha debaixo

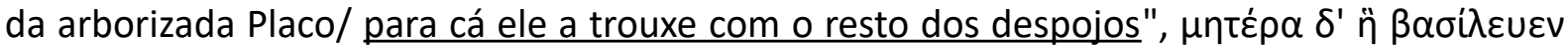
ن்

Este é o único passo em que se menciona o pagamento de um resgate por uma cativa de guerra, e deve provavelmente ser entendido muito mais como parte da caracterização do Aquiles pré-cólera do que um elemento constitutivo do tema. O tratamento dos vencidos, de acordo com os critérios de objetividade da narrativa homérica, constitui uma oportunidade para o exercício de caracterização moral dos personagens. Contraste-se o tratamento que o comandante Agamêmnon cogita dar ao vencidos em seus discursos de exortação, em que ele expressa não apenas o desejo de matar os inimigos, mas também de matar a memória deles:

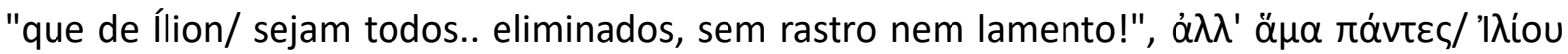




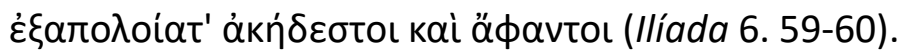

É importante observar que a descrição das vítimas do saque e destruição de cidades encontradas nas narrativas embutidas tem pontos de contato com exortações e lamentos. É notável a tendência, tanto no lamento, quanto nas narrativas, de mencionar o campeão que defendia a cidade. O narrador menciona Mines e Epístrofo (Ilíada 2. 691-692); Andrômaca cita Eécion (Ilíada 6. 415); Briseida, no lamento para Pátroclo, cita o marido, possivelmente, Mines (Ilíada 19. 285). Por óbvio, os lamentos de Hécuba, Helena e Andrômaca durante o enterro de Heitor nomeiam corretamente o campeão troiano.

Todavia as descrições do resto das vítimas masculinas nestas narrativas costumam ser breves e menos coloridas, por exemplo, a narrativa de Odisseu sobre o saque de Ismaro: "aí

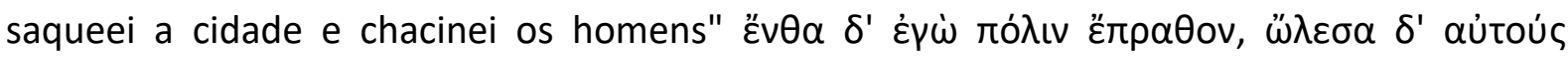
(Odisseia 9. 40). Entretanto, quando o discurso se aproxima muito da provocação, como de Tlepólemo para Sarpédon, ou Aquiles para Eneias, o narrador-personagem pode se demorar mais com esses detalhes, como que para irritar seu interlocutor: "[Héracles] enviuvou suas

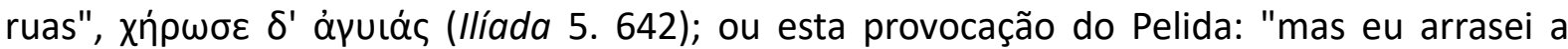

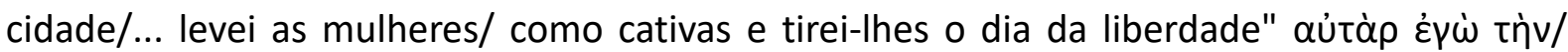

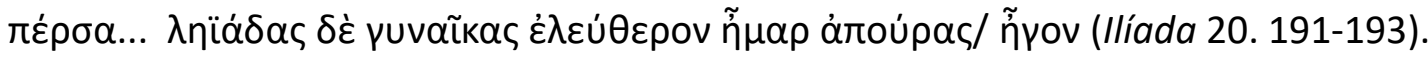

Enquanto a dicção das narrativas desinteressadas (que não tencionam suscitar reação emocional específica do interlocutor, como discursos de reprovação ou provocação) mostra os eventos narrados de maneira direta e simples, as exortações e os lamentos apresentam o

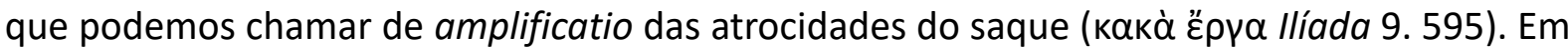
relação às vítimas masculinas, os discursos de exortação dos aqueus são pontuais. Odisseu, por exemplo, mostra que as naus se reuniram em Áulis "trazendo desgraças a Príamo e aos

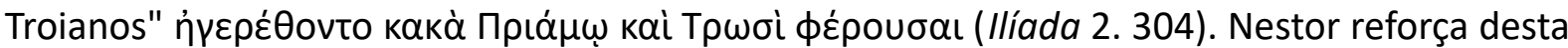
maneira o propósito da expedição, para "aos Troianos trazerem a morte e o destino", 'Арүعĩoı

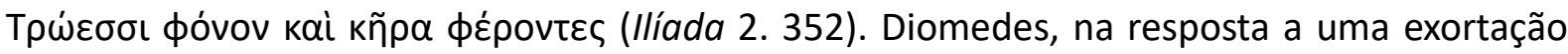
de Agamêmnon, fantasia sobre a possibilidade dos soldados aqueus "chacinarem os Troianos

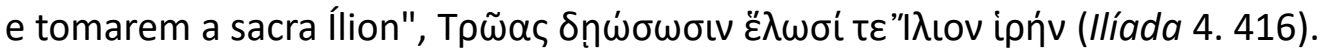

Quando se trata de mulheres e crianças, todavia, os discursos de exortação assumem um tom mais sinistro. Agamêmnon, por exemplo "pela nossa parte, levaremos as esposas... e 


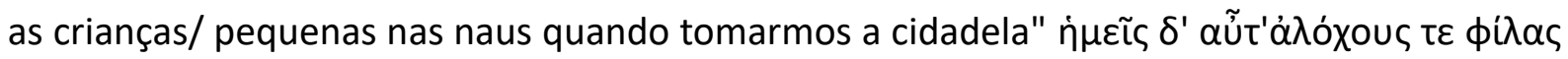

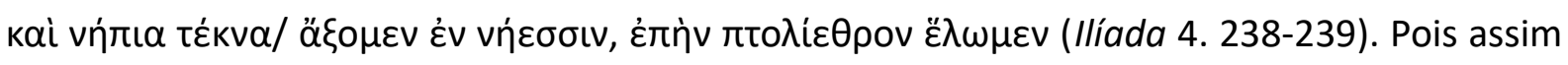
Agamêmnon imagina o futuro de mulheres e crianças, depois que a população masculina for chacinada e seus cadáveres devorados por aves de rapina: "[dos troianos] decerto os abutres

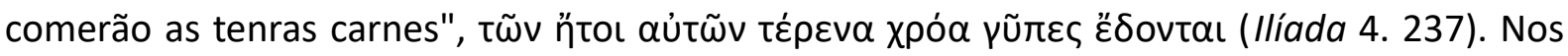
lamentos das troianas essas imagens se repetem como pesadelo. Andrômaca prefigura, por exemplo, o dia em que as troianas pederão a liberdade e, escravizadas, serão primeiramente levadas nas naus para a Grécia, depois submetidas a trabalhos ultrajantes sob o olhar severo do senhor: "as... esposas e crianças pequenas/ elas... rapidamente partirão nas côncavas

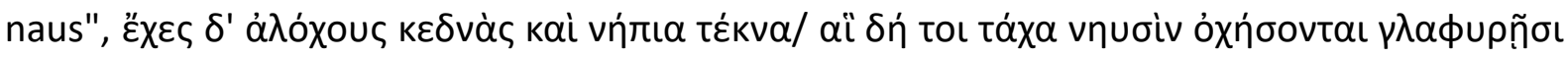
(Ilíada 24. 730-731). Esta descrição recorrente é amplificada no lamento de Andrômaca com a inclusão da sua própria pessoa e do filho entre os escravos transportados e os trabalhos duros a que ele será submetido: "desempenharás tarefas aviltantes/ [trabalhando] à frente

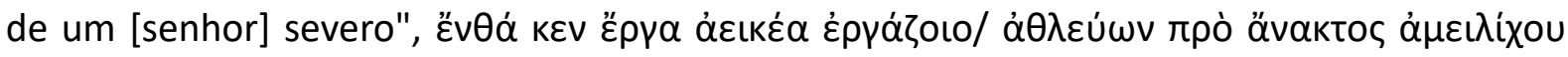
(Ilíada 24. 733-734).

Em outro discurso de exortação, Nestor encoraja o exército aqueu a permanecer em solo troiano neste teor: "ninguém se apresse a regressar para casa/ antes que ao lado da

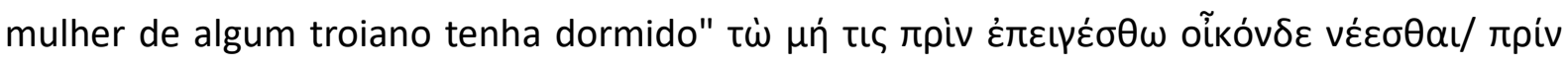

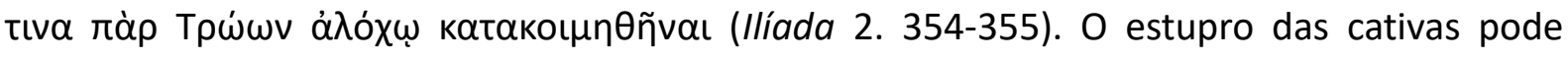
também estar presente no mais dramático lamento da llíada. De tal forma Príamo lamenta a morte dos filhos e a futura escravização das filhas: "depois de ter visto muitos horrores/...

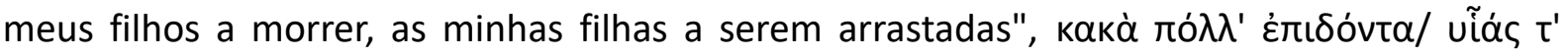

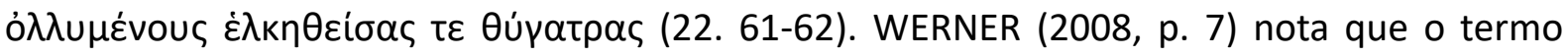
$\dot{\varepsilon} \lambda \kappa \eta \theta \varepsilon \dot{\sigma} \sigma \alpha \varsigma$ traduzido por LOURENÇO (2013) como "arrastadas" pode significar "estupradas".

Como citamos em outras discussões, o destino das crianças, principalmente daqueles pertencentes à aristocracia local, pode ir além da escravização e dos trabalhos humilhantes a que Andrômaca faz referência em seu lamento. Agamêmnon, por exemplo, contempla matar os troianos ainda no ventre das mães: "que nenhum [troiano] fuja da íngreme desgraça/ às

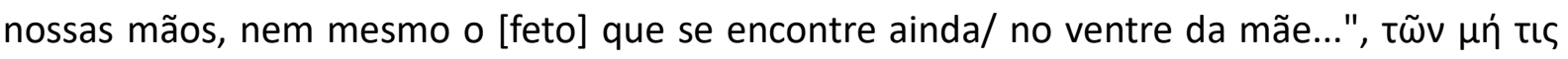

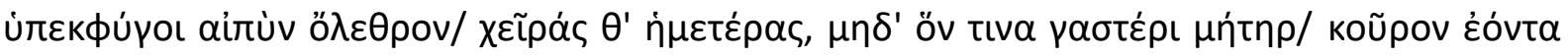


фદ́po (llíada 6.57-59). Andrômaca considera a possibilidade de que Astíanax seja jogado da muralha por um dos aqueus: "[um aqueu] pegará em ti pela mão e te lançará da muralha,

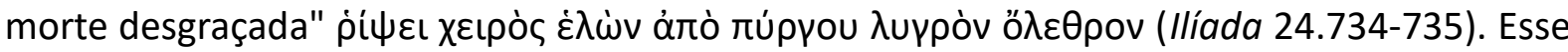
tema era provavelmente encarado na épica como uma gravíssima transgressão, uma vez que ele é explorado nesses termos no poema Saque de ílion. Segundo nossas fontes, Neoptólemo mata Príamo no interior do templo de Zeus; Menelau mata Deífobo e reencontra Helena; Ájax estupra Cassandra no templo de Atena; e Odisseu mata Astíanax (arg. 11-18 Severyns; Apolodoro, Epítome 5.20-23; Pausânias 10.25) $\left({ }^{163}\right)$.

Desta forma, notamos uma clara expansão gradual na forma como o tema representa as vítimas de guerra. Nas analepses o narrador ou o narrador-personagem podem mencionar a captura dos despojos de guerra, de mulheres, ou de ambos; ao passo que a referência ao destino das crianças conserva-se reservado às exortações de batalha, aos lamentos fúnebres e, em uma única ocorrência, aos símiles (Odisseia 8. 525). Assim, a cena de mulheres, idosos e crianças na muralha na representação do escudo de Aquiles seria, portanto, a única alusão que não se enquadraria nesses critérios. Porém, esta característica única da cena se poderá justificar com base no conteúdo da descrição do armamento, característico do símile $\left({ }^{164}\right)$.

A analepse em discursos de reprovação ou provocação ocupa posição intermediária neste esquema. Ao mesmo tempo que ela pode apresentar o tratamento das vítimas de uma forma tão sucinta quanto as narrativas fora deste contexto, o narrador-personagem parece livre para elaborar sua descrição (até metaforicamente em uma instância). Porém, é preciso ressaltar que essas formas de discurso jamais apresentam a amplificação do tema, como nas exortações e lamentos, uma vez que os propósitos dessa forma de discurso são diferentes.

163 FINGLASS (2014, pp. 347-354).

164 M. W. EDWARDS (1988, p. 278). 


\section{CONCLUSÃO}

Anotadas as narrativas, é possível constatar a grande variedade de contextos em que ocorrem. (1) O discurso de provocação, lançado por um guerreiro ao seu oponente no calor da batalha, é um desses contextos. Tlepólemo acusa Sarpédon de não estar à altura dos seus ancestrais contando-Ihe o relato de uma façanha de Héracles: "[Héracles] saqueou a cidade

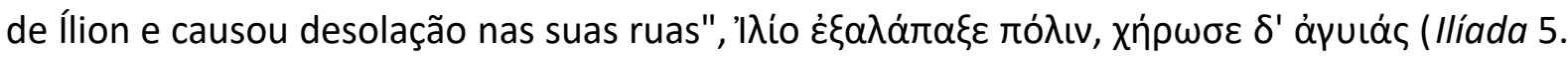
641). O saque da cidade de Lirnesso também surge neste tipo de discurso. Aquiles provoca Eneias lembrando-Ihe que da última vez que os dois se encontraram em campo de batalha, Eneias fugiu e não pode defender a cidade: "...fugiste sem olhar para trás/ Dali fugiste para

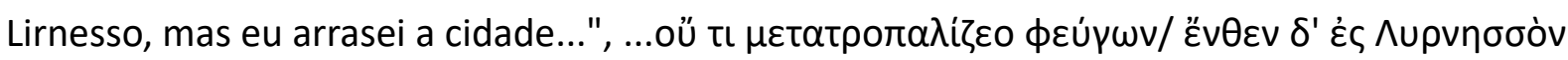

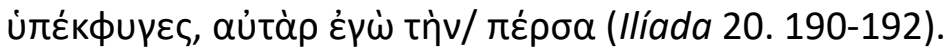

Antes da provocação de Aquiles, Lirnesso e Pédaso já haviam sido mencionadas pelo troiano Eneias em outro contexto. (2) As cidades são invocadas como motivo para não fazer oposição a um guerreiro oponente que, sempre com a ajuda divina, vem obtendo sucessos repetidos: "[Aquiles] me assarapantou com a lança/ do Ida... e arrasou Lirnesso e Pédaso",

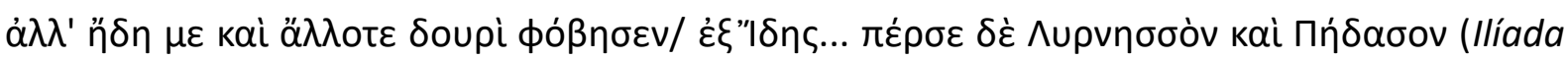
9. 90-92).

A menção à destruição da cidade de Tebas ocorre em contexto pouco mais ou menos parecido: (3) como resposta a um discurso de reprovação proferido pelo general aos seus subordinados. Agamêmnon reprova a inação de Diomedes argumentando que ele não está à altura do seu pai, Tideu. O escudeiro de Diomedes retruca evidenciando que ele e Diomedes destruíram a cidade de Tebas, enquanto Tideu teve fracasso nesta empresa: "conquistamos a sede da heptápila Tebas/ quando ambos juntamos uma hoste menor sob uma muralha mais

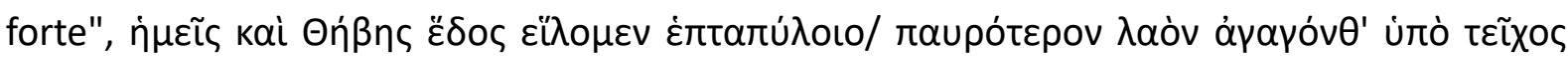
äpeıov (Ilíada 4. 406-407).

O tema da captura e destruição de cidades pode aparecer também em narrativas de personagens na forma de (4) recapitulações. Este é o caso da tomada de Ismaro e Tebas-sobPlaco. A história da primeira é recapitulada por Odisseu no início dos Apologoi: "aí saqueei a 


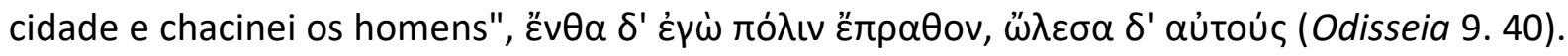
A tomada de Tebas-sob-Placo é recapitulada por Aquiles durante a embaixada: "Fomos para Tebas, a sagrada cidade de Eécion/ saqueamo-la e de lá trouxemos os despojos"

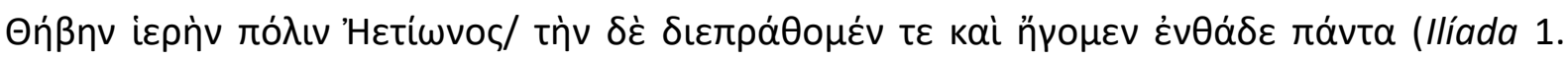
366-367).

Relatos de conquista de cidade também podem ser encontrados em duas passagens em que personagens expressam um (5) desejo irrealizável. Esse é o caso do saque de Néricon pelo jovem Laerte. Depois de ouvir as notícias sobre o massacre dos pretendentes no palácio de Odisseu, o ancião manifesta o desejo irrealizável de ter outra vez a mesma força de sua juventude: "igual à que tinha quando conquistei Néricon, a bem construída/ cidade", oĩoৎ

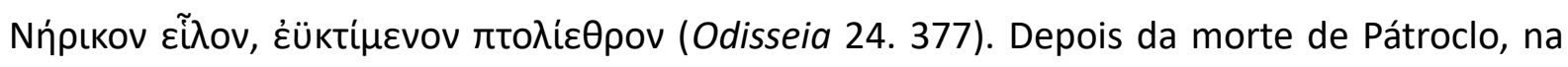
cena de reconciliação com Agamêmnon, Aquiles expressa desejo semelhante em relação ao apresamento de Briseida: "quem me dera que nas naus Ártemis a tivesse matado com uma

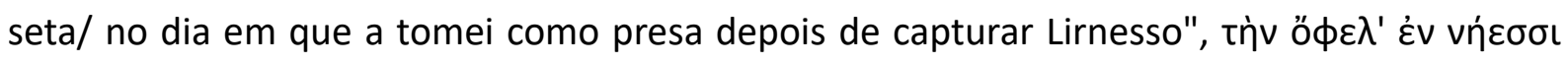

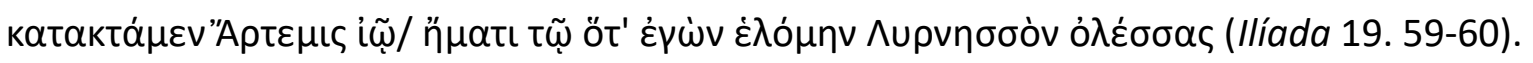

O contexto do (6) lamento fúnebre também é importante para esse tema. Pelo menos em duas ocasiões notamos a menção ao saque de cidades. Andrômaca, em seu lamento que combina as características distintivas do lamento com o discurso de reprovação, observa que: "meu pai foi morto pelo divino Aquiles/ que arrasou a cidadela bem habitada dos Cilícios",

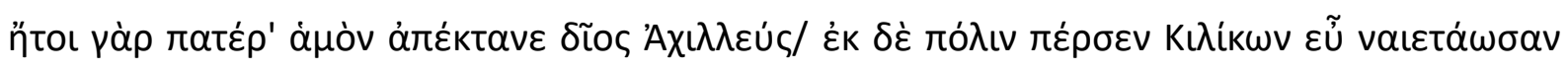
(Ilíada 6. 414-415). Briseida também, no lamento pela morte de Pátroclo, depois de ressaltar as mortes do marido e dos irmãos, observa: "[Aquiles] destruiu a cidade do divino Mines",

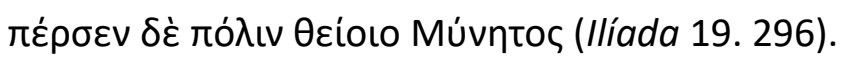

O saque mais famoso da literatura grega, o saque de Troia, encontra-se claramente no contexto mais extraordinário de todo o corpus. A destruição da cidade é narrada em uma (7) canção por ocasião de um banquete.

O ambiente mais recorrente no corpus de micronarrativas, todavia, é (8) a descrição de um determinado objeto ou cativa de guerra mediante uma oração subordinada relativa ou temporal. O saque de Ismaro é referido dessa maneira por Odisseu ao mencionar que os seus camaradas ainda estavam bem providos de jarras de vinho ismárico: "cada tripulação 


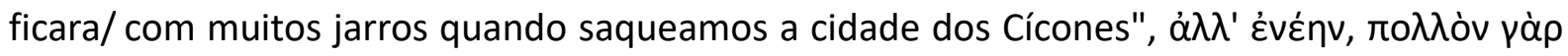

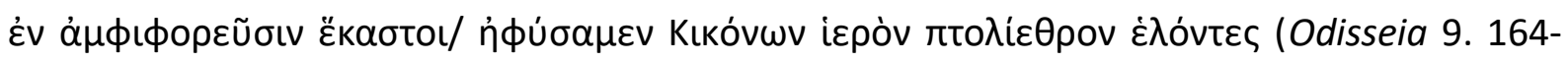
165). Os saques de Tebas-sob-Placo, Lirnesso, Lesbos, Esquiro e Tênedo são mencionados neste cenário, inclusive a tomada das ilhas de Lesbos, Esquiro e Tênedo, diferentemente das demais, não é mencionada em nenhum outro contexto. É como se as tradições diferentes de poesia épica que, segundo alguns estudiosos, envolviam esses lugares só tivessem deixado vestígios em virtude das cativas que surgem em uma cena ou outra da llíada.

Finalmente, comentamos duas outras narrativas que, muito embora não consistam efetivamente relatos de destruição, mesmo assim foram incluídas nesta tese por sua riqueza de detalhes: (9) a descrição da cidade sob cerco no escudo e (10) a narrativa paradigmática de Fênix no episódio da embaixada enviada à tenda de Aquiles.

Em nosso corpus de cidades saqueadas, os narradores não se mostraram em absoluto interessados no exame das causas da destruição das cidades, de maneira que, dentre todas elas, apenas o debate entre Tlepólemo e Sárpedon sobre arrasamento de Troia por Héracles esboça uma possibilidade: a loucura ou desvario de Laomedonte: "[Héracles] arrasou a sacra

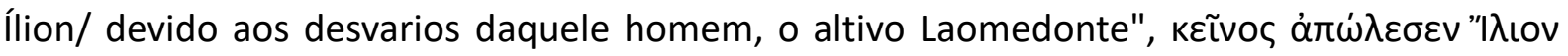

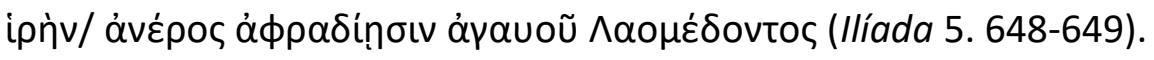

O narrador homérico, quando integra o cerco bem-sucedido de uma cidade, costuma servir-se da primeira pessoa do singular para narrar semelhante façanha. Assim faz Odisseu

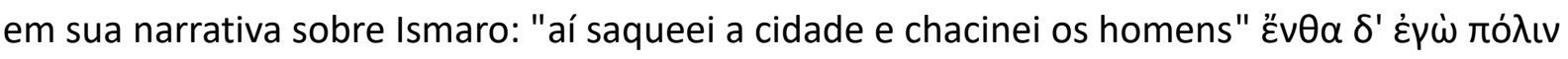

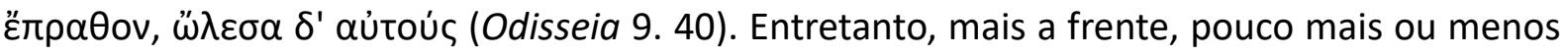
no mesmo contexto, Odisseu se refere ao arrasamento no plural: "saqueamos a cidade dos

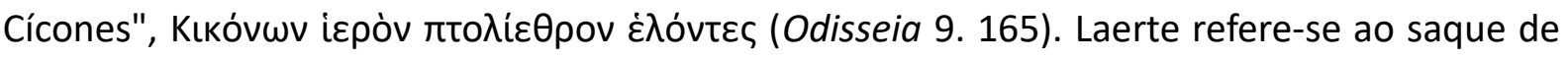
Néricon empregando a primeira pessoa do singular: "conquistei Néricon a bem construída

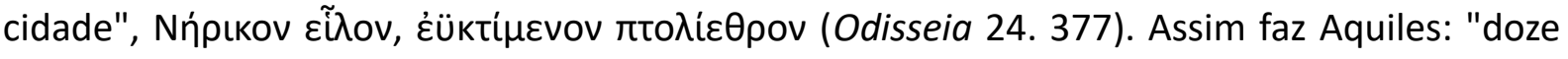
cidades... eu destruí com as minhas naus;/ por terra afirmo [serem] onze na terra fértil de

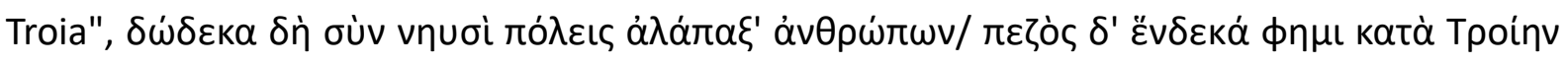

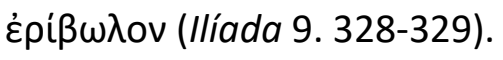

O emprego do plural em llíada 4 provavelmente não faz referência ao exército, mas antes a Estênelo e Diomedes: "conquistamos a sede da heptápila Tebas", n் 


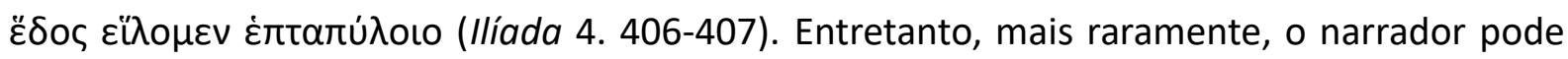
usar o plural, como Aquiles: "Fomos para Tebas, a sagrada cidade de Eécion/ saqueamo-la e

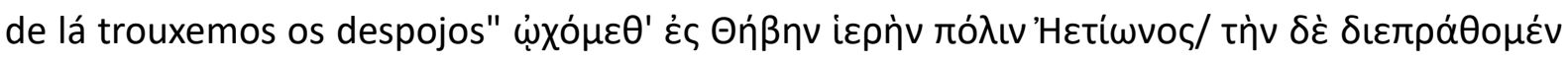

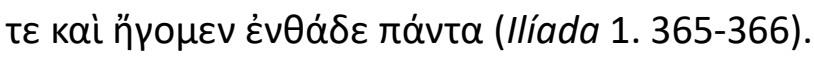

A utilização da terceira pessoa do singular, naturalmente, também é bastante comum. O narrador-observador se serve dela para descrever a tomada de Lirnesso, Pédaso, Esquiro e Tênedo por Aquiles, como, por exemplo, ao descrever a procedência da cativa Hecameda:

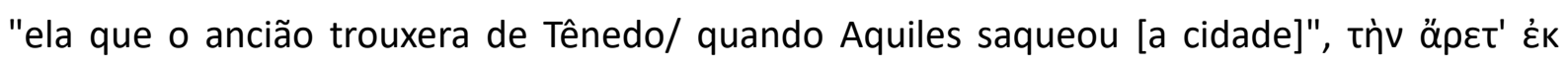

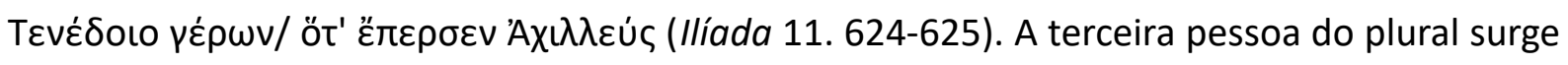
duas vezes para descrever o saque de Troia pelos aqueus (sob o comando de Odisseu). Sobre o embuste do cavalo o poema diz que: "[Odisseu] levou para a acrópole pelo dolo/ depois de

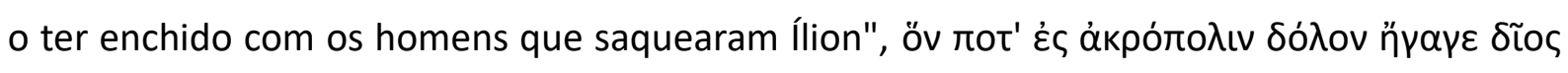

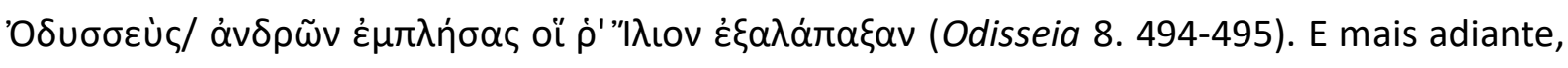

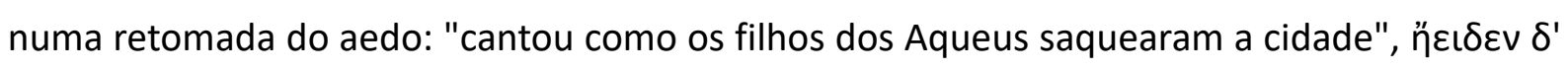

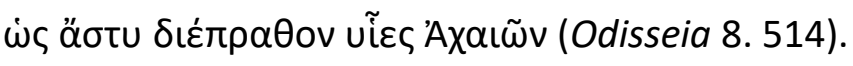

Ao longo dos Capítulos 2, 3 e 4 constatamos que as narrativas relacionadas ao tema do saque de cidades apresentam um determinado roteiro de atividades de guerra. Não é muito frequente uma menção ao (1) deslocamento do exército. A movimentação das tropas, todavia, pode ser constatada no relato sobre Ismaro: "de ílio fui levado pelos ventos até os

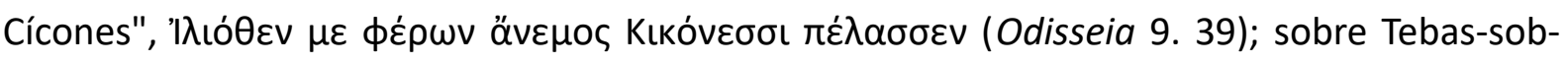

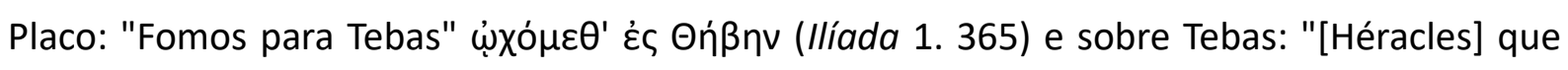

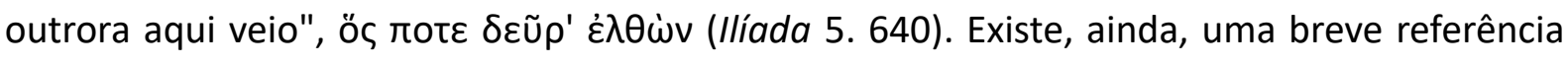
ao estabelecimento de acampamento por parte da força expedicionária dos sete em algum local nas proximidades de Tebas: "Depois que partiram e estavam já a caminho, chegaram ao

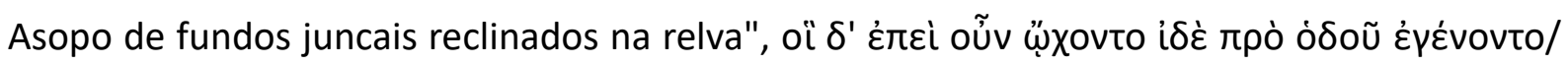

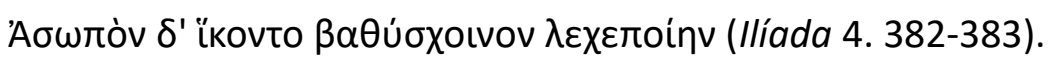

Nesse contexto podemos inserir um unidade detectada em três narrativas: a menção ao (2) tamanho do contingente arregimentado para o assédio da cidade. No terceiro capítulo desta tese $\left({ }^{165}\right)$, relacionei a menção ao tamanho do exército à facilidade ou dificuldade com

165 Supra, p. 83. 
que o arrasamento da cidade sitiada é levado a efeito. Tlepólemo detalha o número reduzido das tropas conduzidas por Héracles em sua investida contra Troia: "só com seis naus e menor

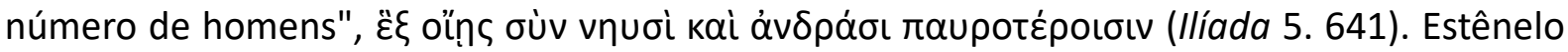
se jacta de ter destruído Tebas em tais condições: "conquistamos a sede da heptápila Tebas/

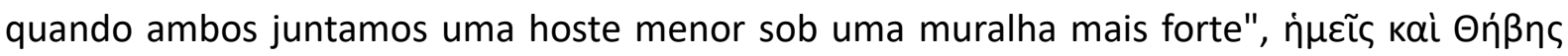

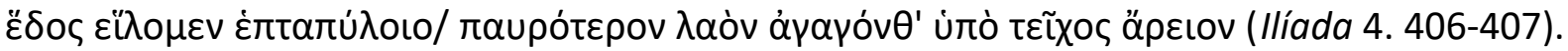
O contrário dessa forma de bravata de vencedor é a valorização da conquista pela ênfase do esforço dispensado nos combates. Desta maneira procede o narrador ao descrever o estado de espírito de Aquiles no Catálogo das Naus: "[Aquiles] trouxera [Briseida] de Lirnesso após

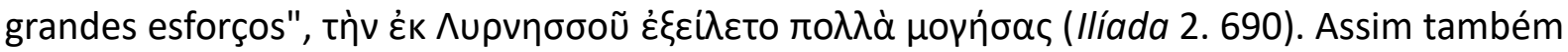
Aquiles procede ao referir-se às ações de combate de que participara: "eu mantive vigília durante muiras noites/ e suportei dias sangrentos em atos de guerra... doze cidades de

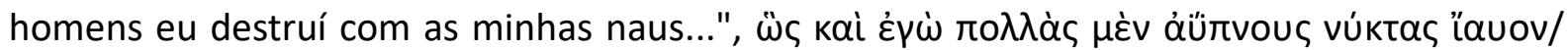

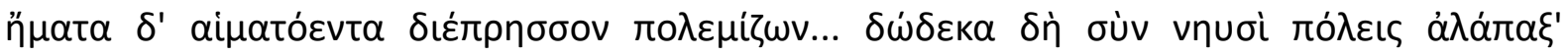

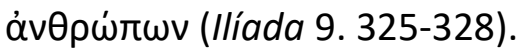

A terceira unidade verificada nas narrativas do corpus é a (3) emboscada. Claramente, o mellhor exemplar é a história do saque da cidade dos troianos. As características que nos permitem analisar dessa forma o episódio foram arroladas no Capítulo 4. A própria narrativa se particulariza dessa forma ao chamar o cavalo de "emboscada" na expressão кои̃ "tocaia cava" (Odisseia 4. 277 e 8. 515). Mas, como observamos, essa não é a única narrativa a apresentar semelhante característica. A tomada das cidades de Tebas-sob-Placo, Lirnesso, Pédaso, e descrição do cerco da cidade retratada no escudo de Aquiles, todas envolvem o tema do roubo ou razia de gado, que deve ser tipificado como uma categoria de emboscada, como mostrou VIEIRA (2016). Eneias, em referência aos saques de Lirnesso e Pédaso, relata

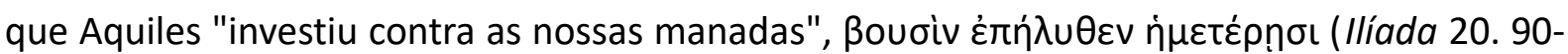
91), numa clara alusão ao roubo de cabeças de gado. O discurso híbrido de Andrômaca toca em ação semelhante ao mencionar a morte dos irmãos da esposa de Heitor em um contexto

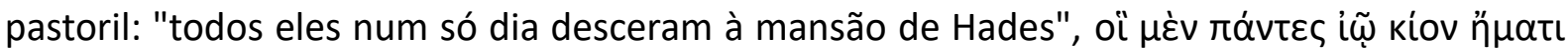

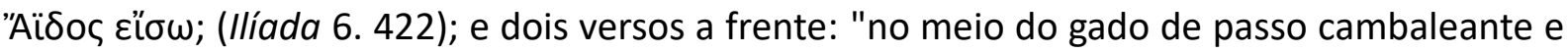

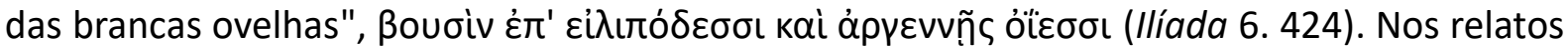


que envolvem as quatro últimas cidades é impossível esmiuçar as relações entre a atividade da razia de gado e do saque da cidade, devendo o estudioso contentar-se com a observação de que às vezes existe uma superposição desses temas em épica homérica.

O elemento das (4) vítimas masculinas é mencionado duas vezes pelos agressores. $\mathrm{O}$ guerreiro Tlepólemo alega a respeito da cidade de Troia que "[Héracles] enviuvou suas ruas",

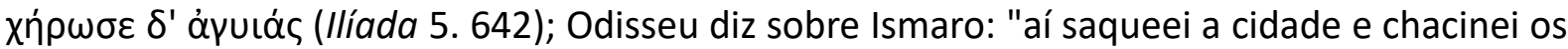

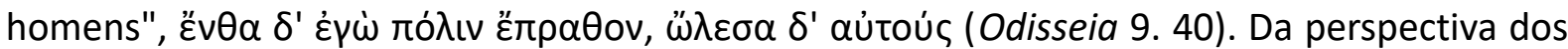
vencidos encontramos três menções. Andrômaca menciona a morte de sete irmãos (Ilíada 6.421); Briseida menciona a morte de três e irmãos e do marido: "vi [meu marido] à frente

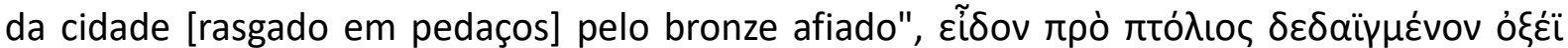

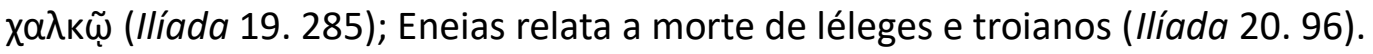

Dentre as vítimas masculinas, uma se assinala: (5) a do campeão/soberano da cidade. Tal figura é mencionada nas narrativas sobre Tebas-sob-Placo, a cidade de Eécion: "arrasou a

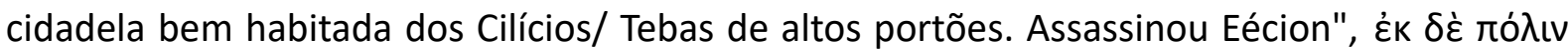

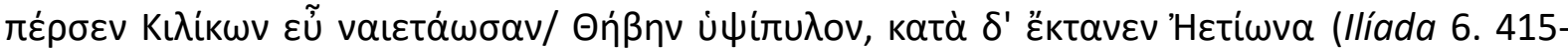
416). Nas passagens que tratam do saque de Lirnesso, Mines é com frequência mencionado:

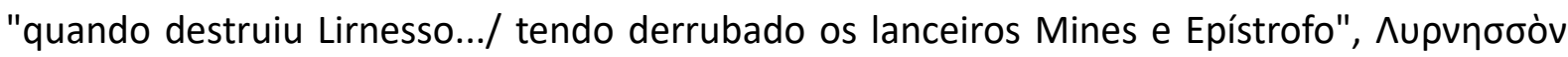

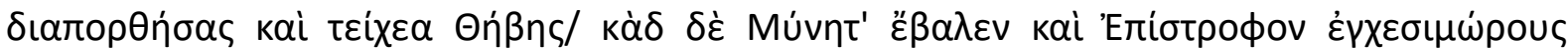
(Ilíada 2. 691-692). Na canção que relata o saque de Troia, Deífobo, evidentemente, cumpre a função de campeão e principal protetor da cidade, sobre o qual o aedo feácio conta que "aí se diz que [Odisseu] ousou a mais terrível das lutas", кعĩ

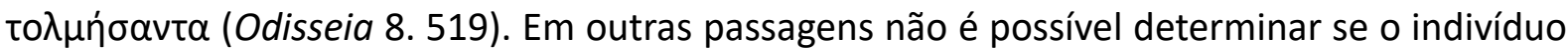
mencionado é ou não o campeão ou soberano, como a referência a Enieu na micronarrativa

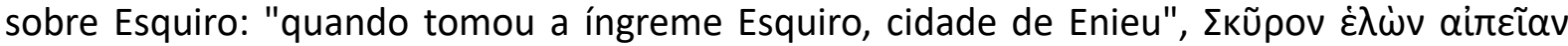

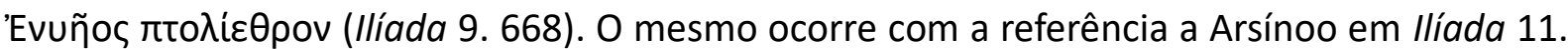
626. Entretanto, as informações são sempre muito concisas e é impossível determinar como ocorreu o enfrentamento, se na forma de duelo ritual, em batalha campal, ou durante uma razia de gado.

Graças à história exemplar sobre Meleagro e Cálidon contada por Fênix foi possível recuperar algumas unidades relativas à batalha e à consumação da captura e destruição de 


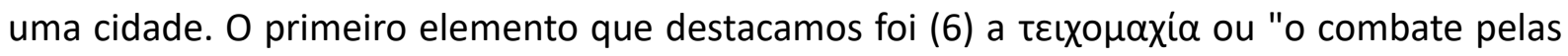
muralhas". Notamos que existem três elementos capazes de invocar sempre a noção de que a cidade corre um grande risco quando sob cerco inimigo: a aproximação da muralhas, o fogo e as pedras arremessadas. Notamos também um padrão de ataque que parece se repetir no contexto da batalha campal como no contexto da emboscada: a segmentação das tropas em companhias ou batalhões. Na cidade retratada no escudo, dois exércitos ou dois batalhões deliberam o que fazer. No episódio em que os troianos finalmente logram romper as defesas dos aqueus, os soldados se dividem em companhias: "e organizados em cinco grupos

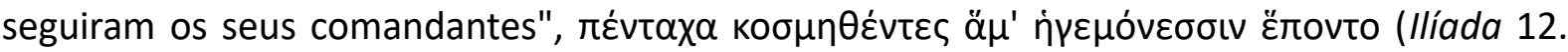
87). No saque de Troia, os guerreiros emboscados no interior do cavalo também dividem-se em grupos ou duplas para atacar a cidade: "cantou como por caminhos diferentes arrasaram

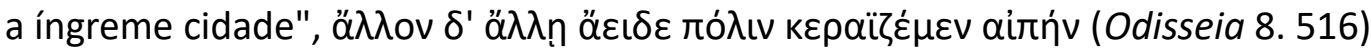

O (7) auxílio divino é outro elemento presente nas narrativas do corpus. Tal como nas narrativas de batalha da Ilíada e da Odisseia, das quais os deuses participam e muitas vezes favorecem um ou outro herói, assim também nas narrativas de saque e destruição a ajuda divinda pode ser pontualmente mencionada. Sobre a expedição dos epígonos contra Tebas, Estênelo diz que ela obteve êxito "tendo acreditado nos portentos divinos e na ajuda de

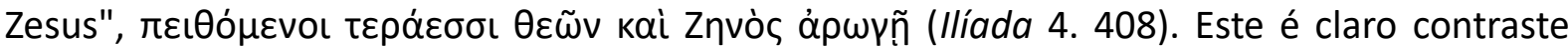
com a expedição amaldiçoada dos sete. Eneias, por sua vez, observa que Aquiles tem sempre uma divindade ao seu lado, quando comenta a destruição de Lirnesso e Pédaso. Na narrativa do saque de Troia, por fim, Odisseu recebe a ajuda de Atena no duelo final contra o campeão

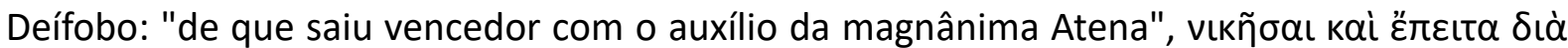

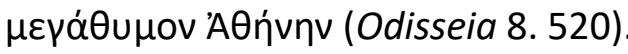

Vencida a batalha e destruída a cidade, a atenção do exército e dos líderes voltam-se para (8) os despojos de guerra, provavelmente, o elemento mais frequente nas narrativas de captura e destruição de cidades. Ismaro, Tebas-sob-Placo, Lirnesso, Lesbos, Esquiro, Tênedo e Troia tem bens e propriedades pilhados pelos aqueus, especialmente por Aquiles, que reúne

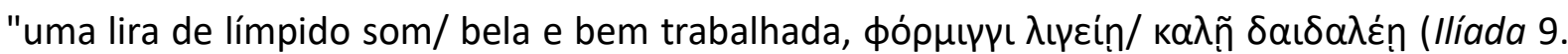

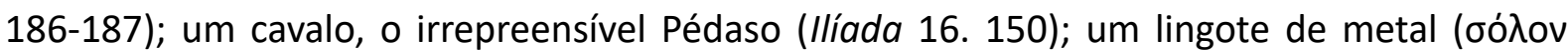

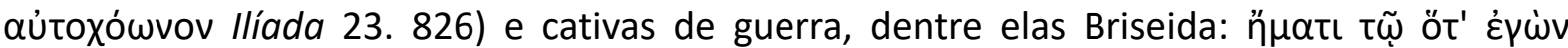




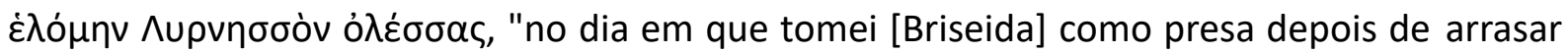
Lirnesso" (Ilíada 19. 60). Como observamos previamente, Odisseu resume o conteúdo dos despojos adequadamente: mulheres e tesouros.

O passo seguinte é (9) a partilha dos despojos, como Odisseu declara após o saque de

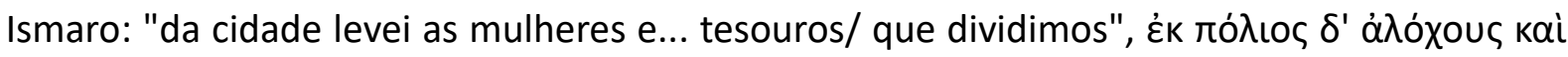

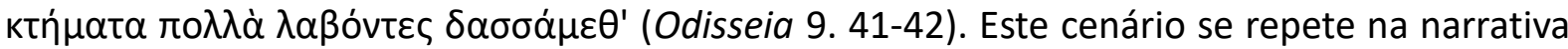
de recapitulação proferida por Aquiles, em que cita a destruição de Tebas-sob-Placo: "bem os

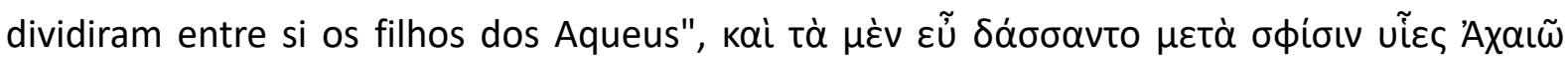
Ilíada 1. 368). Na divisão do butim, as passagens observam às vezes uma peculiaridade: um guerreiro, como prêmio ou prerrogativa, pode escolher os itens que the agradarem mais, como as sete mulheres provenientes da ilha de Lesbos que Agamêmnon escolhe para si: "as

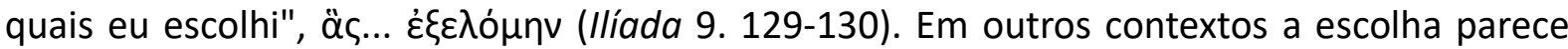
ser efetuada pelo exército em comum acordo, publicamente: "Para o Atrida escolheram

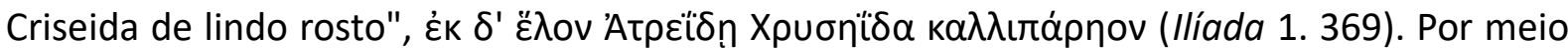
dessa mesma forma de divisão Hecameda é escolhida pelo exército para Nestor: "tinham-na escolhido/ os Aqueus para ele, porque de todos ele era o melhor no conselho", ñv oi 'Axaıi//

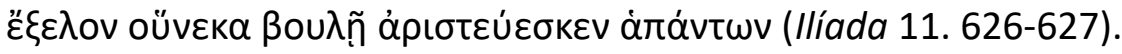

Em uma ocasião, na narrativa de Odisseu sobre a conquista de Ismaro, os homens ali residentes executam um (10) contragolpe e expulsam os agressores (Odisseia 9. 39-66).

Como temos observado e defendemos nesta tese, o destino reservado a mulheres e crianças é mencionado sempre de forma oblíqua, indireta, por meio de símiles, prolepses, contrafactuais, exortações, lamentos, sempre indiretamente. Quando Aquiles narra o saque de Lirnesso, com efeito, menciona a escravização das mulheres daquela comunidade: "mas

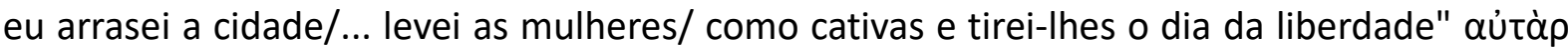

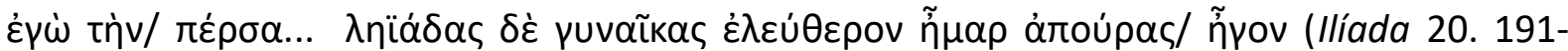
193). Como observamos no Capítulo 4, isso acontece por causa do contexto de provocação em que a narrativa está inserida. Os horrores da guerra, tais como o estupro das mulheres, o infanticídio permanecem no plano da imaginação ou da retórica em Homero.

A captura e destruição de uma cidade jamais é efetiva e verdadeiramente narrada nos poemas homéricos. Esta ideia permanece restrita às recordações e retomadas do narrador e 
dos seus personagens e à expressão do desejo ou receio de que venha a ocorrer no futuro, ou seja, a destruição de uma cidade está limitada aos processos de representação narrativa da analepse e da prolepse. Embora o poeta homérico e seu público aprovem representações bastante extremas de violência nos poemas e, a bem da verdade, divirtam-se imensamente com elas, existem limites que, mesmo para este tipo de poesia, não se pode cruzar. Grande parte do prazer de se ouvir um poema de guerra vem das descrições detalhadas de mortes violentas, como por exemplo, quando Agamêmnon corta braços e pernas e rola um cadáver desmembrado para o meio da multidão (Ilíada 9.146), quando Ájax e seu irmão arremessam a cabeça cortada do inimigo como uma bola de boliche nos pés de Heitor (llíada 13.203), ou quando o cérebro de um soldado vaza por sua órbita ocular ao ser atingido por uma lança (Ilíada 17.296), quando o tutano jorra de um ferimento na coluna vertebral (llíada 20.482),

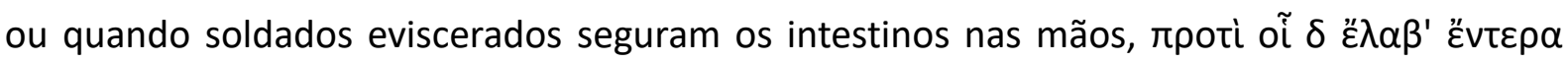

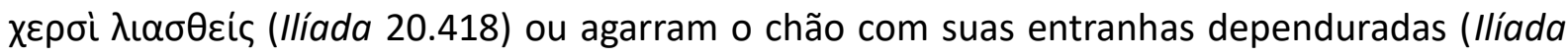
13.507), quando a cabeça, boca e nariz de um guerreiro tomba em frente às pernas e joelhos ainda eretos (Ilíada 14.465), um soldado prova o sabor da ponta da lança que lhe arrebentou dentes e amputou a língua (Ilíada 5.73), o golpe especial do Cretense que estica um homem no chão tal como um verme (llíada 13.652), quando os olhos saltam para fora das órbitas e capotam na poeira (llíada 14.616, 16.741) $\left.{ }^{166}\right)$.

É uma lista grande, de dar inveja aos diretores de cinema da categoria de um Quentin

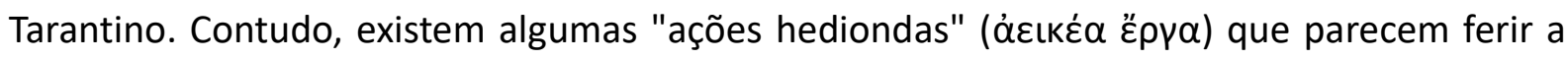
sensibilidade épica e, portanto, sua descrição está interditada ao poeta homérico, como, por exemplo, ferimentos nos órgãos genitais. Homero parece querer evitar ao máximo esse tipo de descrição. O mais próximo que chegamos de semelhante narração encontra-se em llíada 13.568-569 e envolve Meríones, talvez não por acaso, o supracitado soldado especialista no

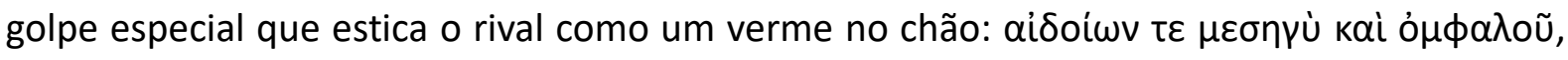

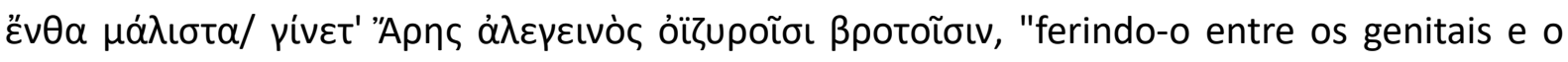
umbigo, onde/ Ares é sobremodo doloroso para os desgraçados mortais".

Atos de canibalismo apesar de poderem ser cogitados por heróis na llíada jamais são colocados em prática. Aquiles, por exemplo, expressa o desejo de devorar as carnes cruas de 
Heitor antes do seu derradeiro combate singular, a $\mu$ ovouaxia: "quem me dera que a força e o ânimo me sobreviesse/ para te cortar a carne e comê-la crua, pelo que fizeste", aï yó

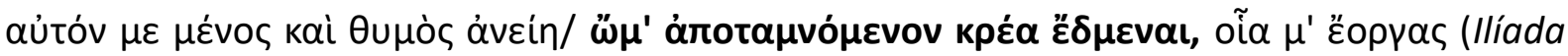
22. 347-348). Isto deve ser entendido como a expressão máxima do desejo de vingança e da raiva e, ao mesmo tempo, como um sintoma da incivilidade e da perda de humanidade. Nos poemas homéricos, além dos animais selvagens apenas Polifemo come carne humana e crua efetivamente. A descrição dos ciclopes e do seu modo de vida expõem claro o significado

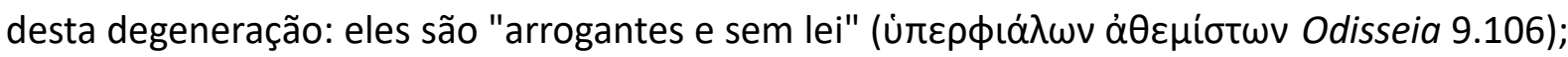

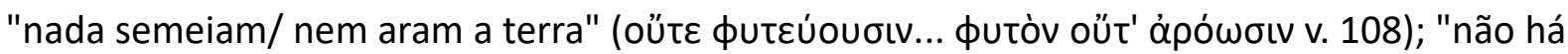

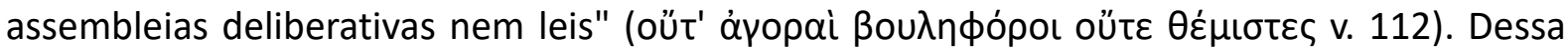
forma, a ideia de comer carne crua, por associação, rebaixa Aquiles ao animal selvagem e ao ciclope, em contraste com o homem civilizado $\left({ }^{167}\right)$.

Apesar da representação de Polifemo, o canibalismo certamente fere a sensibilidade épica e permanece, portanto, no âmbito da retórica. É algo que os heróis dizem abertamente e às vezes desejam muito intensamente fazer, porém jamais são representados fazendo para todos os efeitos. Este é um paralelo importante para o tema estudado neste trabalho, já que o tratamento dado no poema às duas ideias é parecida. Além de deslocar o tempo narrativo deste tema para o passado e para o futuro, os nossos relatos são sempre abreviados e só em circunstâncias muito particulares, como no caso do tratamento dos vencidos em lamentos e em exortações, o tema recebe amplificação.

167 Ver M. CLARKE (1995) para uma análise detalhada desta passagem. 


\section{REFERÊNCIAS BIBLIOGRÁFICAS}

ALDEN, Maureen. "Kalydon", in Margalit FINKELBERG (Org.) The Homer Encyclopedia. Vol. III. Malden: Willey-Blackwell, pp. 430-431, 2011 a.

. "Oineus", in Margalit FINKELBERG (Org.) The Homer Encyclopedia. Vol. III. Malden: Willey-Blackwell, p. 596, 2011b.

ANDERSON, M J. The Fall of Troy in Early Greek Poetry and Art. Oxford: Clarendon Press, 1997.

. "Returns", in Margalit FINKELBERG (Org.) The Homer Encyclopedia. Vol. III. Malden: Willey-Blackwell, pp. 743-745, 2011 a.

. "Wooden Horse", in Margalit FINKELBERG (Org.) The Homer Encyclopedia. Vol. III. Malden: Willey-Blackwell, pp. 941-942, 2011b.

AREND, Walter. Die Typischen Szenen bei Homer. Berlim: Weidmann, 1933.

ASSUNÇÃO, T. R. "Boa comida em banquetes como razão para arriscar a vida: o discurso de Sarpédon e Glauco (Ilíada XII 310-328)", Nuntius Antiquus 1, pp. 1-17, 2008.

AUSTIN, N. "The function of digressions in the Iliad", Greek, Roman and Byzantine Studies 7, pp. 295-312, 1966.

BACHVAROVA, M.; DUTSCH, D.; SUTER, A. (Orgs.) The Fall of Cities in the Mediterranean: Commemoration in Literature, Folk-Song, and Liturgy. Cambridge: CUP, 2016.

BAKKER, Egbert J. Linguistics and Formula in Homer: Scalarity and the Description of the Particle per. Baltimore: The Johns Hopkins University Press, 1988 . (Org.) A Companion to the Ancient Greek Language. Malden, MA: Wiley-Blackwell, 2010.

The Meaning of Meat and the Structure of the Odyssey. Cambridge: CUP, 2013.

BARKER, E.; CHRISTENSEN, J. "Even Herakles Had to Die: Homeric 'Heroism', Mortality, and the Epic Tradition", Trends in Classics (Special Issue) 6 (2), pp. 249-277, 2014.

BASSET, S. E. "The Proems of the Iliad and the Odyssey", The American Journal of Philology 44, pp. 339-348, 1923. . The Poetry of Homer. Berkeley: University of California Press, 1938. 
BEEKES, Robert. "On the Structure of the Greek Hexameter: O' Neill Interpreted", Glotta 50, pp. 1-10, 1972 . Etymological Dictionary of Greek. Leiden: Brill, 2010.

BENVENISTE, Émile. Le vocabulaire des institutions indo-européennes. Tome 2: Pouvoir, Droit, Religion. Paris: Les Édition de Minuit, 1969.

BERG, N. "Parergon metricum. Der Ursprung des griechischen Hexameters", Münchener Studien zur Sprachwissenschaft 37, pp. 11-36, 1978.

BERNABÉ, Alberto. Poetae Epici Graeci. Testimonia et Fragmenta. Bibliotheca Scriptorum Graecorum et Romanorum Teubneriana. Munich; Leipzig: De Gruyter, 1996-2007.

BOWIE, A. M. Homer: Odyssey Books 13-14. Cambridge: CUF, 2014.

BURGESS, Jonathan S. "The Epic Cycle and Fragments", in J. M. FOLEY (Org.) A Companion to Ancient Epic. Malden, MA: Blackwell, pp. 344-352, 2005.

. The Tradition of the Trojan War in Homer and the Epic Cycle. Baltimore; London: Johns Hopkins University Press, 2001.

. "Skyros", in Margalit FINKELBERG (Org.) The Homer Encyclopedia. Vol. III. Malden: Willey-Blackwell, p. 808, 2011a.

. "Tenedos", in Margalit FINKELBERG (Org.) The Homer Encyclopedia. Vol. III. Malden: Willey-Blackwell, p. 847, 2011b.

CABRAL, L. A. A Biblioteca de Pseudo-Apolodoro e o estatuto da mitografia. Tese (Doutorado em Linguística) - Insituto de Estudos da Linguagem da UNICAMP: Campinas, 2013.

CAIRNS, D. L. (Org.) Oxford Readings in Classical Studies: Homer's lliad. Oxford: OUP, 2002.

. "Time" in Margalit FINKELBERG (Org.) The Homer Encyclopedia. Vol. III. Malden:

Willey-Blackwell, p. 489, 2011a.

CAMEROTTO, Alberto. Fare gli eroi. Le storie, le emprese, le virtù: composizione e racconto nell'epica greca arcaica. Padova: Il Poligrafo, 2009.

CHANTRAINE, Pierre. Grammaire homérique I-II. Paris: Klincksieck, 1958-1963.

Dictionnaire étymologique de la langue grecque. Histoire des mots. Paris: Klincksieck, 1968-1980.

CINGANO, E. "Oedipodea" in Marco FANTUZZI; Christos TSAGALIS (Org.) The Greek Epic Cycle and Its Ancient Reception. Cambridge: CUP, pp. 213-225, 2015 a. 
. "Epigonoi", in Marco FANTUZZI; Christos TSAGALIS (Org.) The Greek Epic Cycle and Its Ancient Reception. Cambridge: CUP, pp. 244-260, 2015b.

CLARK, W. P. "Iliad IX, 336 and the Meaning of äגoxos in Homer", Classical Philology 35, pp. 188-190, 1940.

CLARKE, H. W. The Art of the Odyssey. Englewood Clifs, NJ: Prentice-Hall, 1967.

CLARKE, M. "Between Lions and Men: Images of the Hero in the Iliad", Greek, Roman, and Byzantine Studies 36, pp. 137-159, 1995.

CLAY, Jenny. The Politics of Olympus. Princeton: Princeton University Press, 1989.

. "The Homeric Hymns as Genre", in Andrew FAULKNER (Org.) The Homeric Hymns: Interpretativ Essays. Oxford: Oxford University Press, 2011.

COOK, John M. The Troad: An Archaeological and Topographical Study. Oxford: Clarendon Press, 1973.

CUNLIFE, Richard J. A Lexicon of the Homeric Dialect. Expanded Edition, with a New Preface of James H. Dee. Norman: University of Oklahoma Press, 2012.

CURRIE, B. "Cypria", in Marco FANTUZZI; Christos TSAGALIS (Org.) The Greek Epic Cycle and Its Ancient Reception. Cambridge: CUP, pp. 281-305, 2015.

DANEK, Georg. "Nostoi", in Marco FANTUZZI; Christos TSAGALIS (Org.) The Greek Epic Cycle and Its Ancient Reception. Cambridge: CUP, pp. 355-379, 2015.

DAVIES, M. Epicorum Graecorum Fragmenta.Göttingen: Vandenhoeck \& Ruprecht, 1988. . The Epic Cycle. London: Bristol Classical Press, 1989. . The Theban Epics. Cambridge, MA: Harvard University Press, 2015.

DEE, James H. Homer. Repertorium Homericae Poiesis Hexametricum. Hildesheim: Georg Olms, 2004.

DE JONG, Irene J. F. A Narratological Commentary on the Odyssey. Cambridge: Cambridge University Press, 2001. . Narrators and Focalizers: the Presentation of the History in the Iliad. London: Bristol Classical Press, 2004.

. Homer: Iliad Book 22. Cambridge: CUP, 2012.

DE JONG, I.; NÜNLIST, R. "From Bird's Eye View to Close Up: The Standpoint of the Narrator in Homeric Epics", in A. BIERL; A. SCHMIDT, A. WILLI (Orgs.) Antike Literatur in neue Deutung 
Leipzig: Sauer, pp. 63-83, 2004.

DESTRÉE, Pierre; MURRAY, Penelope (Orgs.) A Companion to Ancient Aesthetics. Malden: Willey-Blackwell, 2015.

DOHERTY, L. E. (Org.) Oxford Readings in Classical Studies: Homer's Odyssey. Oxford: OUP, 2009.

DUÉ, C. Homeric Variations on a Lament by Briseis. Lanham, MD: Rowman \& Littlefield, 2002. "Thebes, Cilician", in Margalit FINKELBERG (Org.) The Homer Encyclopedia. Vol. III. Malden: Willey-Blackwell, pp. 861-862, 2011a.

. "Lirnessos", in Margalit FINKELBERG (Org.) The Homer Encyclopedia. Vol. II. Malden: Willey-Blackwell, pp. 491-492, 2011b.

. "Pedasos", in Margalit FINKELBERG (Org.) The Homer Encyclopedia. Vol. II. Malden: Willey-Blackwell, p. 634, 2011c.

. "Lesbos", in Margalit FINKELBERG (Org.) The Homer Encyclopedia. Vol. II. Malden: Willey-Blackwell, pp. 472-473, 2011d.

DUÉ, C.; EBBOTT, M. Iliad 10 and the Poetics of Ambush: A Multitext Edition with Essays and Commentary. Cambridge, MA: Harvard University Press, 2010.

DURANTE, M. Sulla preistoria della tradizione poetica greca II. Risultanze della comparazione indoeuropea. Roma: Edizioni Dell' Ateneo, 1976.

EBBOTT, Mary. "Error 404: Theban Epic not Found" Trends in Classics 2 (2) pp. 239-258, 2010. . "Allies in Fame: Recruiting Warriors in the Theban and Trojan Epic Tradition", Trends in Classics (Special Issue) 6 (2) pp. 319-335, 2014.

EDER, Birgitta. "Pleuron", in Margalit FINKELBERG (Org.) The Homer Encyclopedia. Vol. II. Malden: Willey-Blackwell, p. 675, 2011.

EDWARDS, Anthony T. "Convention and Individuality in Iliad 1", Harvard Studies in Classical Philology 84, pp. 1-28, 1980. .Achilles in the Odyssey. Königstein, 1985.

EDWARDS, M. W. "Type-scenes and Homeric Hospitality", Transactions of the American Philological Association 105, pp. 51-72, 1975. . Homer: Poet of the Iliad. Baltimore: Johns Hopkins University Press, 1988. . The Iliad. A Commentary. Volume 5: Books 17-20. Cambridge: CUP, 1991. 
. "Homer and Oral Tradition: The Type-scene", Oral Tradition 7, pp. 284-330, 1992.

FANTUZZI, M.; PESTAGOSTINI, R. (Orgs.) Struttura e Storia dell' esametro greco. Roma:

Gruppo editoriale internazionale, 1996.

FANTUZZI, Marco; TSAGALIS, Christos (Org.) The Greek Epic Cycle and Its Ancient Reception. A Companion. Cambridge: CUP, 2015.

FAULKNER, A. The Homeric Hymn to Aphrodite. Introduction, Text and Commentary. Oxford:

Oxford University Press, 2008. . (Org.) The Homeric Hymns: Interpretativ Essays. Oxford: OUP, 2011.

FINGLASS, P. J. "lliou Persis", in Marco FANTUZZI; Christos TSAGALIS (Org.) The Greek Epic Cycle and Its Ancient Reception. Cambridge: CUP, pp. 344-354, 2015.

FINKELBERG, M. "The first song of Demodocus", Mnemosyne 40, pp. 128-132, 1987.

.. "Patterns of Human Error in Homer", Journal of Hellenic Studies 115, pp. 15-28, 1995. . The Birth of Literary Fiction in Ancient Greece. Oxford: Clarendon Press, 1998.

. (Org.) The Homer Encyclopedia. Malden: Willey-Blackwell, 2011.

FOLEY, John M. Oral-Formulaic Theory and Research: An Introduction and Annotated Bibliography. New York: Garland, 1985.

. The Theory of Oral Composition: History and Metodology. Bloomington: Indiana University Press, 1988.

. Immanent Art: From Structure to Meaning in Traditional Oral Epic. Bloomington:

Indiana University Press, 1991.

. Traditional Oral Epic: The Odyssey, Beowulf, and the Serbo-Croatian Return Song.

Berkeley; Los Angeles; London: University of California Press, 1993.

. (Org.) Teaching Oral Traditions. New York: Modern Language Association, 1998. . Homer's Traditional Art. Pennsylvania: Pennsylvania State University Press, 1999. . How to Read an Oral Poem. Urbana; Chicago: University of Illinois Press, 2002. . (Org.) A Companion to Ancient Epic. Malden, MA: Blackwell, 2005.

FORD, Andrew. Homer: The Poetry of the Past. Ithaca: Cornell University Press, 1994. . "Epic as a Genre", in I. MORRIS; B. POWELL (Orgs.) A New Companion to Homer. Leiden: Brill, 1997, pp. 396-414.

FOWLER, Robert (Org.) The Cambridge Companion to Homer. Cambridge: CUP, 2004. 
FRANKLIN, J. C. "The Wisdom of the Lyre: Soundings in Ancient Greece, Cyprus and the Near East", in HICKMANN \& R. EICHMANN (Orgs.) Musikarchäologie im Kontext: Archäologische Befunde, historische Zusammenhänge, soziokulturelle Beziehungen. Serie Studien zur Musikarchäologie 5, pp. 379-398, 2006.

. "Phorminx"in Margalit FINKELBERG (Org.) The Homer Encyclopedia. Vol. II. Malden: Willey-Blackwell, pp. 663-665, 2011.

GAERTNER, J. F. "The Homeric Catalogues and Their Function in Epic Narrative", Hermes 129, pp. 298-304, 2011.

GANTZ, Timothy. Early Greek Myth: A Guide to Literary and Artistic Sources. Baltimore: Johns Hopkins University Press, 1993.

GARVIE, A. F. Homer: Odyssey. Books 6-8. Cambridge: Cambridge University Press, 1994.

GATTI, Ícaro. A Crestomatia de Proclo: tradução integral, notas e estudo da composição do códice 239 da Biblioteca de Fócio. Diss. FFLCH-USP, 2012.

GIANNESI, P. Récits des voies. Chant et cheminement em Grèce archaïque. Grenoble: Jérôme Millon, 2006.

GIRARD, P. "Comment a dû se former l'lliade", Revue des Études Grecques 15, pp. 229-287, 1904.

GONZÁLEZ, José M. The Epic Rhapsode and his Craft. Homeric Performance in a Diachronic Perspective. Cambridge, MA: Harvard University Press, 2013.

GRAZIOSI, B.; HAUBOLD, J. The Resonance of Epic. London: Duckworth, 2005. Homer: Iliad Book 6. Cambridge: Cambridge University Press, 2010.

GRIFFIN, J.; HAMMOND, M. "Critical Appreciations VI: Homer's Iliad 1.1-52", Greece \& Rome 29, pp. 126-142, 1982.

GRIFFIN, J. Homer on Life and Death. Oxford: Clarendon Press, 1980.

HAINSWORTH, J. B. The Iliad. A Commentary. Volume 3: Books 9-12. Cambridge: CUP, 1993. HAJNAL, I. "Der epische Hexameter im Rahmen der Homer-Troia-Debatte", in C. ULF (Org.) Der neue Streit um Troia. Eine Bilanz. München: pp. 217-231, 2003a. . Troia aus sprachwissenchaftlicher Sicht.Die Struktur einer Argumentation. Innsbruck: Institut für Sprachwissenschaft, 2003b.

HASLAM, M. W. "Homeric Words and Homeric Metre: Two Doublets Examined", Glotta 54, 
pp. 204-211, 1976.

HAUBOLD, J. "Greek Epic: a Near Eastern Genre?", Proceedings of the Cambridge Philological Society 48, pp. 1-19, 2002.

HAUG, D.; WELO, E. "The Proto-Hexameter Hypothesis: Perspectives for further Research", Symbolae Osloenses 76, pp. 130-6, 2001.

HEUBECK, A.; WEST, S.; HAINSWORTH, J. B; HOEKSTRA, A.; RUSSO, J. \& FERNÁNDEZGALIANO, M. A Commentary on Homer's Odyssey. Oxford: OUP, 1988-1992.

HOLOKA, J. "'Looking Darkly' (YחO $\triangle P A I \Delta \Omega N$ ): Reflections on Status and Decorum in Homer", Transaction of the American Philological Association 113, pp. 1-16, 1983.

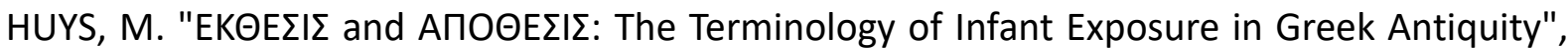
L'Antiquité Classique 58, pp. 190-197, 1989.

IRSCHMER, J. Götterzorn bei Homer. Leipzig: Harrassowitz, 1950.

JANKO, Richard. The lliad. A Commentary. Volume 4: Books 13-16. Cambridge: CUP, 1994.

JENSEN, Minna S. The Homeric-Question and Oral-Formulaic Theory. Copenhagen: Museum Tusculanum Press, 1980.

Writing Homer: a Study Based on Results from Modern Fieldwork. Copenhagen: Det Kongelige Danske Videnskabernes Selskab, 2011.

KATZ, Marilyn Arthur. "The Divided World of Iliad VI", in H. FOLEY (Org.) Reflections of Women in Antiquity. New York: Routledge, pp. 19-44, 1981.

KATZ, Joshua T. "Inherited Poetics", in Egbert J. BAKKER (Org.) A Companion to the Ancient Greek Language. Malden, MA: Wiley-Blackwell, pp. 357-369, 2010.

KELLY, Adrian. A Referential Commentary and Lexicon to Homer, Iliad 8. Oxford: OUP, 2007. . "The Mourning of Thetis: Allusion and the Future in the lliad", in F. MONTANARI; A. RENGAKOS; C. TSAGALIS (Orgs.) Homeric Contexts: Neonalysis and the Interpretation of Oral Poetry. Berlim: De Gruyter, pp. 211-256, 2012. . "Homeric Battle Narrative and the Ancient Near East", in Douglas CAIRNS \& Ruth SCODEL (Orgs.) Defining Greek Narrative. Edinburgh: Edinburgh University Press, pp. 29-54, 2014.

KELLY, A. "Ilias Parva", in Marco FANTUZZI; Christos TSAGALIS (Org.) The Greek Epic Cycle and Its Ancient Reception. Cambridge: CUP, pp. 318-354, 2015. 
KIRK, G. S. The Iliad. A Commentary. Volume 1: Books 1-4. Cambridge: CUP, 1985. The lliad. A Commentary. Volume 2: Books 5-8. Cambridge: CUP, 1990.

KRIETER-SPIRO, M. Homer's Iliad: The Basel Commentary. Book III. Berlin; Boston: De Gruyter, 2015.

LANATA, G. Poetica preplatonica: testimonianze e frammenti. Firenze: La Nuova Italia, 1963.

LEAF, Walter. Troy: A Study in Homeric Geography. London: Macmilla, 1912.

LLEWELLYN-JONES, L. Aphrodite's Tortoise. The Veiled Women of Ancient Greece. Swansea: Classical Press of Wales, 2003.

LORD, Albert B. The Singer of Tales. Cambridge, MA: Harvard University Press, 1960.

"Perspectives on Recent Work on the Oral Traditional Formula", Oral Tradition 1, pp. 467-503, 1986.

. "Characteristics of Orality", Oral Tradition 2, pp. 54-72, 1987.

. Epic Singers and Oral Tradition. Ithaca, NY: Cornell University Press, 1991.

LOUDEN, Bruce. "Pivotal Contrafactual in Homeric Epic", Classical Antiquity 12, pp. 181-198, 1993.

The Iliad. Structure, Myth, and Meaning. Baltimore: Johns Hopkins University Press, 2006.

. Homer's Odyssey and the Near East. Cambridge: Cambridge University Press, 2011a. . "Theoxeny" in Margalit FINKELBERG (Org.) The Homer Encyclopedia. Vol. III. Malden: Willey-Blackwell, pp. 867-868, 2011 b.

LOURENÇO, Frederico. Homero: Odisseia. São Paulo: Companhia das Letras, 2011. . Homero: Ilíada. São Paulo: Companhia das Letras, 2013.

MACKIE, H. "Song and Storytelling: an Odyssean Perspective", Transactions of the American Philological Association 127, pp. 77-95, 1997.

MACLEOD, Colin. Homer: Iliad Book 24. Cambridge: Cambridge University Press, 1982. . "Homer on Poetry and the Poetry of Homer", in D. CAIRNS (Org.) Oxford Readings in Classical Studies: Homer's Iliad. Oxford: OUP, pp. 295-310, 2001 [1983].

MAGNELLI, E. "Studi recenti sull' origine dell' esametro: Un profilo critico", in M. FANTUZZI \& R. PRETAGOSTINI (Orgs.) Struttura e Storia dell' esametro greco. Roma: Gruppo editoriale internazionale, v. 2, pp. 111-137, 1996. 
MARKS, J. "The Ongoing Neikos: Thersites, Odysseus, and Achilleus", The American Journal of Philology 123, pp. 1-31, 2005.

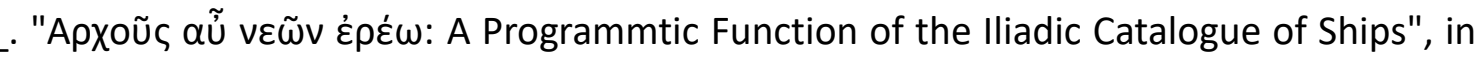
F. MONTANARI; A. RENGAKOS; CH. TSAGALIS (Org.) Homeric Contexts: Neoanalysis and the Interpretation of Oral Poetry. Berlin; Boston: De Gruyter, pp. 101-112, 2012.

MINCHIN, E. Homer and the Resources of Memory. Some applications of Cognitive Theory to the Iliad and the Odyssey. Oxford: Oxford University Press, 2001.

MONRO, David B.; ALLEN, Thomas W. Homeri Opera. Oxford Classical Texts. Oxford: Oxford University Press, 1917-1920.

MORRIS, lan; POWELL, Barry (Orgs.) A New Companion to Homer. Leiden: Brill, 1997.

MORRIS, Sarah. "The Sacrifice of Astyanax: Near Eastern Contributions to the Siege of Troy", in J. B. CARTER \& S. P. MORRIS (Org.) The Ages of Homer: A Tribute to Emily Townsend Vermeule. Austin: University of Texas Press, pp. 221-245, 1995.

MORRISON, J. V. "The Function and Context of Homeric Prayers", Hermes 119, pp. 145-157, 1991.

MOST, G. W. Hesiod: The Shield, Catalogue of Women, Other Fragments. Cambridge, MA: Cambridge University Press, 2007.

MUELLNER, L. The Anger of Achilles: Mênis in Greek Epic. Ithaca: Cornell University Press, 2005.

MURRAY, Penelope. "Poetic Inspiration in Early Greece", Journal for Hellenic Studies 101, pp. 87-100, 1981.

. "Poetic Inspiration", in Pierre DESTRÉE; Penelope MURRAY (Orgs.) A Companion to Ancient Aesthetics. Malden: Willey-Blackwell, pp. 158-174, 2015

NAGLER, M. N. Spontanety and Tradition a Study on the Oral Art of Homer. Berkeley: UCP, 1974.

NAGY, Gregory. Comparative Studies in Greek and Indic Meter. Cambridge, MA: Harvard University Press, 1974.

. "On the Origins of the Greek Hexameter: Synchronic and Diachronic Perspectives" in B BROGYANYI (Org.) Studies in Diachronic, Synchronic, and Typological Linguistics. Festschrift for Oswald Szemérenyi on the Occasion of his 65th Birthday. Amsterdam: 
John Benjamins, pp. 611-631, 1979 .

. Pindar's Homer: the Lyric Possession of an Epic Past. Baltimore: Johns Hopkins University Press, 1990.

. The Best of the Achaeans: Concepts of the Hero in Archaic Greek Poetry. Baltimore: Johns Hopkins University Press, 1999.

. "Is There an Etymology for the Dactylic Hexameter?", in Homer's Text and Language. Urbana and Chicago, pp. 144-156, 2004.

. "The Epic Hero", in J. M. FOLEY (Org.) A Companion to Ancient Epic. Malden, MA: Blackwell, pp. 71-89, 2005.

. Homer the Classic. Washington: Center for Hellenic Studies, 2009.

. The Ancient Greek Hero in 24 Hours. Cambridge, MA: Harvard University Press, 2013.

NICKEL, Roberto. "The Wrath of Demeter: Story Pattern in the Hymn to Demeter", Quaderni Urbinati di Cultura Classica 1, pp. 59-82, 2003.

NOTOPOULOS, J. "Studies in Early Greek Oral Poetry", Harvard Studies in Classical Philology 68, pp. 1-77, 1964.

NÜNLIST, R. \& DE JONG, I. "Homeric Poetics in Keywords", in D. OLSON (Orgs.) Homer's Iliad: The Basel Commentary. Prolegomena. Berlin; Boston: De Gruyter, pp. 164-176, 2015.

OLSON, D. (Orgs.) Homer's Iliad: The Basel Commentary. Prolegomena. Berlin; Boston: De Gruyter, 2015.

PACHE, C. "The Walls in Homeric Epic", Trends in Classics (Special Issue) 6 (2), pp. 278-296, 2014.

PAGLIARO, A. Saggi di critica semantica. Messina-FIrenze: G. d'Anna, 1953.

PARRY, Adam (Org.) The Making of The Homeric Verse: The Collected Papers of Milman Parry.

Oxford: Oxford University Press, 1987.

PULLEYN, Simon. Homer: Iliad Book 1. New York: OUP, 2000.

REDFIELD, J. M. "The Proem of the Iliad: Homer's Art", Classical Philology 74, pp. 95-110, 1979.

RICHARDSON, N. The lliad. A Commentary. Volume 6: Books 21-24. Cambridge: CUP, 1993. RUTHERFORD, R. B. Homer: Odyssey 19-20. Cambridge: CUP, 1992. 
SAÏD, Suzanne. Homer \& the Odyssey. Cambridge: Cambridge University Press, 2011.

SALE, W. M. "In Defence of Milman Parry: Renewing the Oral Theory", Oral Tradition 11: 374412, 1996.

. "The Oral-Formulaic Theory Today", in J. WATSON (Org.) Speaking Volumes: Orality and Literacy in the Greek and Roman Worlds. Leiden: Brill, 53-80, 2001.

SAMMONS, B. "A Tale of Tydeus: Exemplarity and Structure in Two Homeric Insets", Trends in Classics (Special Issue) 6 (2) pp. 297-318, 2014.

. Device and Composition in the Greek Epic Cycle. Oxford: OUP, 2017.

SCHEIN, Seth. The Mortal Hero: An Introduction to the Iliad. Berkeley: University of California Press, 1984.

. "The Iliad: Structure and Interpretation", in I. MORRIS; B. POWELL (Orgs.) New Companion to Homer. Leiden: Brill, pp. 345-359, 1997.

SCHMITT, R. Dichtung und Dichtersprache in indogermanischer Zeit. Wiesbaden: Otto Harrassowitz, 1967.

SCODEL, R. "Bardic Performance and Oral Tradition in Homer", The American Journal of Philology 119, pp. 171-194, 1998.

SEGAL, C. The Theme of the Mutilation of the Corpse. Mnemosyne Supplements. Leiden: Brill, 1971.

SEVERYNS, A. Recherches sur la Chrestomathie de Proclos. Le Codex 239 de Photius: Étude Paléographique et critique (t. I); Texte, Traduction et Commentaire (t. II). La Vita Homeri et les Sommaires du Cycle: Étude Paléographique et critique (t. III); Texte et Traduction (t. IV). Paris, Belles Lettres, 1977.

SLATKIN, Laura M. Power of Thetis and Selected Essays. Cambridge, MA: Harvard University Press, 2011.

SOLMSEN, F.; MELKERBACH, R.; WEST, M. L. Hesiodi Theogonia, Opera et Dies, Scutum, Fragmenta Selecta. Oxford Classical Texts. Oxford: Oxford University Press, 1990.

STAFFORD, E. Herakles. God and Heroes of the Ancient World. London: Routledge, 2012.

STURTEVANT, E. H. "Word-Ends and Pauses in the Hexameter", The American Journal of Philology 42, pp. 289-308, 1921.

TAPLIN, O. "The Shield of Achilles Within the Iliad", Greece \& Rome 27, pp. 1-21, 1980. 
TSGALIS, C. (Org.) Theban Resonances in Homeric Epic = Trends in Classics (Special Issue). Berlin; Munich; Boston, 2014.

THALMANN, W. G. Conventions of Form and Thought in Early Greek Epic Poetry. Baltimore: Johns Hopkins University Press, 1984.

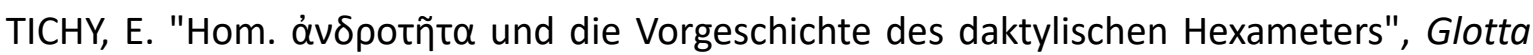
59, pp. 28-67, 1981a.

. "Beobachtungen zur homerischen Synizese" Münchener Studien zur Sprachwissenschaft 40, pp. 187-222, 1981b.

THIEL, Helmut van. Ilias un Iliaden. Basel; Stuttgart: Schwabe, 1982. . Homeri Odyssea. Hildesheim: G. Olms, 1991. . Homeri llias. Hildesheim: G. Olms, 1996.

TORRES-GUERRA, J. B. "Thebaid", in Marco FANTUZZI; Christos TSAGALIS (Org.) The Greek Epic Cycle and Its Ancient Reception. Cambridge: CUP, pp. 226-243, 2015.

VAN GRONINGEN, B. A. La composition littéraire archaïque grecque. Amsterdam: N. V. Noord-Hollandsche Uitgevers Maatschappi, 1958.

VAN WEES, Hans van. Status Warriors. War, Violence, and Society in Homer and History. Amsterdam: J. C. Gieben, 1992. . "Homeric Warfare", in I. MORRIS; B. POWELL (Orgs.) New Companion to Homer. Leiden: Brill, pp. 668-693, 1997. . Greek Warfare. Myths and Realities. London: Duckworth, 2004.

VEMEULE, E. Aspects of Death in Early Greek Art and Poetry. Berkeley: University of California Press, 1981.

VIEIRA, L. O tema da razia de gado (boelasia) na épica homérica. Tese (Doutorado em Letras Clássicas) - Faculdade de Filosofia, Letras e Ciências Humanas, USP: São Paulo, 2016.

VILLA, D. Ecos tradicionais nos catálogos de heróis abatidos na llíada. Dissertação (Mestrado em Letras Clássicas) - Faculdade de Filosofia, Letras e Ciências Humanas, USP: São Paulo, 2018.

VON DER MÜHLL, P. Homeri Odyssea. Bibliotheca Scriptorum Graecorum et Romanorum Teubneriana. Stuttgart: B. G. Teubner, 1962.

WALSH, T. R. Fighting Words and Feuding Words: Anger and the Homeric Poems. Lanham, 
MD: Lexington Books, 2005.

WATKINS, Calvert. How to Kill a Dragon: Aspects os Indo-european Poetics. New York; Oxford: Oxford University Press, 1995.

WERNER, C. "Wives, Widows, and Children: War Victms in Iliad Book II", L'Antiquité Classique 77, pp. 1-17, 2008. . "O mundo dos heróis na poesia hexamétrica grega arcaica", Romanitas - Revista de Estudos Grecolatinos, n. 2, pp. 20-41, 2013a. . Hesíodo: Trabalhos e Dias. São Paulo: Hedra, 2013b.

WEST, M. L. "Greek Poetry 2000-700 BC", Classical Quarterly 23, pp. 179-92, $1973 a$. . "Indo-European Metre", Glotta 51, pp. 161-87, 1973b. . Ancient Greek Music. Oxford: Oxford University Press, 1992. . "Homer's Meter", in I. MORRIS; B. POWELL (Orgs.) New Companion to Homer. Leiden: Brill, pp. 218-37, 1997. . The East Face of Helicon: West Asiatic Elements in Greek Poetry and Myth. Oxford: Clarendon Press, 1996. . Homeri llias. Bibliotheca Scriptorum Graecorum et Romanorum Teubneriana. Munich; Leipzig: De Gruyter, 1998-2000. . Greek Epic Fragments: From the Seventh to the Fifth Centuries BC. Loeb Classical Library. Cambridge, MA: Harvard University Press, 2003. . Indo-european Poetry and Myth. Oxford: Oxford University Press, 2007. . The Making of the Iliad: Disquisition and Analytical Commentary. Oxford: Oxford University Press, 2011. . The Epic Cycle: A Commentary on the Lost Troy Epics. Oxford; New York: Oxford University Press, 2013. . The Making of the Odyssey. Oxford: Oxford University Press, 2014.

WHITMAN, Cedric. Homer and the Heroic Tradition. Cambridge, MA; London: Harvard University Press, 1958.

YOUNGER, J. G. Music in the Aegean Bronze Age. Jonsered: Paul Äströms Förlag, 1998. 